\title{
Phase 2 TWR Steam Reforming Tests for Sodium-Bearing Waste Treatment
}

\author{
N. R. Soelberg \\ D. W. Marshall \\ D. D. Taylor \\ S. O. Bates
}

January 2004

Idaho National Engineering and Environmental Laboratory Bechtel BWXT Idaho, LLC 


\title{
Phase 2 TWR Steam Reforming Tests for Sodium-Bearing Waste Treatment
}

\author{
Nicholas R. Soelberg \\ Douglas W. Marshall \\ Dean D. Taylor \\ Steven O. Bates
}

January 2004

\section{Idaho National Engineering and Environmental Laboratory Environmental Research and Development Idaho Falls, Idaho 83415}

\author{
Prepared for the \\ U.S. Department of Energy \\ Assistant Secretary for Environmental Management \\ Under DOE Idaho Operations Office \\ Contract DE-AC07-99ID13727
}




\begin{abstract}
About one million gallons of acidic, hazardous, and radioactive sodiumbearing waste (SBW) is stored in stainless steel tanks a the Idaho Nuclear Technology and Engineering Center (INTEC), which is a major operating facility of the Idaho National Engineering and Environmental Laboratory (INEEL). Steam reforming is a candidate technology being investigated for converting the SBW into a road ready waste form that can be shipped to the Waste Isolation Pilot Plant in New Mexico for interment.

Fluidized bed steam reforming technology, licensed to ThermoChem Waste Remediation, LLC (TWR) by Manufacturing Technology Conversion International, was tested in two phases using an INEEL (Department of Energy) fluidized bed test system located at the Science Applications International Corporation (SAIC) Science and Technology Applications Research Center in Idaho Falls, Idaho. The Phase 1 tests were reported earlier. The Phase 2 tests are reported here.
\end{abstract}

For Phase 2, the process feed rate, reductant stoichiometry, and process temperature were varied to identify and demonstrate how the process might be optimized to improve operation and product characteristics. The first week of testing was devoted primarily to process chemistry and the second week was devoted more toward bed stability and particle size control. 


\section{EXECUTIVE SUMMARY}

About one million gallons of acidic, hazardous and radioactive, sodium-bearing waste (SBW) is stored in stainless steel tanks at the Idaho Nuclear Technology and Engineering Center (INTEC), which is a major operating facility of the Idaho National Engineering and Environmental Laboratory (INEEL). Steam reforming is a candidate technology being investigated for treatment of the SBW into a road ready waste form that can be shipped to the Waste Isolation Pilot Plant in New Mexico for interment.

Fluidized bed steam reforming technology, licensed to ThermoChem Waste Remediation, LLC (TWR) by Manufacturing Technology Conversion International (MTCI), was tested in two phases using an INEEL (Department of Energy) fluidized bed test system. This first phase of tests showed that SBW could be successfully converted into an alkali carbonate powder without serious agglomeration, but the emphasis was on process viability and reliability rather than on production and optimization.

Phase 2 tests were performed in October 2003 to evaluate the MTCI process under a wider range of conditions and using a more efficient liquid reductant. The process feed rate, reductant stoichiometry, and process temperature were varied to identify and demonstrate how the process might be optimized to improve operation and product characteristics. The tests also demonstrated the performance of a Maximum Achievable Control Technology (MACT)-compliant off-gas system.

TWR participated in the Phase 2 tests to ensure that the tests satisfactorily represented the MTCI technology to the extent possible. During test planning stages, TWR provided recommendations for process chemistry modifications and reviewed test objectives. Under subcontract to the INEEL, TWR personnel observed the test series, provided consultation and recommendations during the tests, and produced an observation report for INEEL.

\section{Test Accomplishments, Conclusions, and Recommendations}

The MTCI steam reforming process provides a thermal and reactive environment to evaporate the liquid SBW simulant feed to a dry, granular product and destroy nitrates in the feed and $\mathrm{NO}_{\mathrm{x}}$ evolved from those nitrates. The product is a water-soluble mixture of carbonate salts in an alkali carbonate matrix.

All of the test objectives were accomplished but one, that of controlling bed particle growth by generating enough "seed" particles to maintain a stable bed particle size distribution. Particle size management systems were not incorporated during this phase of testing. The accomplishments include:

- $\quad 99.8 \%$ destruction of nitrates in the feed.

- $\quad 92 \%$ destruction of $\mathrm{NO}_{\mathrm{x}}$ relative to the maximum theoretical emissions.

- $\quad$ SBW simulant feed rate was quadrupled relative to Phase 1 tests. Simulants fed included a WM180 simulant containing synthetic heel solids.

- $\quad$ The bed product was free of residual, unreacted carbon. Fines captured on the off-gas filter had less than $7 \%$ residual carbon.

- $\quad$ Simulated waste mass reduction was $88 \%$.

- $\quad$ Off-gas emissions were MACT-compliant for carbon monoxide, mercury, chlorine, and total hydrocarbons (THC)

- The distribution of heavy metals and radionuclide surrogates was quantified. All species of regulatory concern were quantitatively retained in either the bed product or in the filter fines. 
About $90 \%$ of the solids in the feed partitioned to the bed product, and the remainder, about $10 \%$, partitioned to the cyclone and filter fines. Only $0.2 \%$ of the input mass was collected in the scrub water.

Mercury partitioned quantitatively to the off-gas. Consistent with expectations, essentially all of the off-gas $\mathrm{Hg}$ was measured in the form of elemental $\mathrm{Hg}$ downstream of the thermal oxidizer. The total mercury was efficiently controlled by the carbon bed (averaged over $99.8 \%$ removal efficiency).

Several areas were identified for additional test operation or technology development/demonstration. These areas are:

- Control of the carbonate bed particle size growth

- $\quad$ Fines recycled to encourage new particle growth

- $\quad$ Better control of feed to control agglomerate formation caused by feed surges, including reconfiguring the feed system to be less prone to plugging by solids

- Better demonstration or improved performance of feed system components

- $\quad$ Operation for longer times to demonstrate long-term performance. 


\section{ACKNOWLEDGMENTS}

Many persons from several different organizations contributed to the success of this test program. Under direction from the INEEL, SAIC operates the DOE-owned fluidized bed test system at the STAR Center. Significant modifications to the prior fluidized bed test system were made before this test series. With collaboration from INEEL, SAIC designed, fabricated, and installed the modifications. Most SAIC personnel involved in the test program performed multiple roles and were involved in many aspects of equipment design, fabrication, and installation, and steam reformer testing.

Many INEEL personnel were involved in the test program. Arlin Olson directed technology development, including steam reformer testing, for SBW treatment. Gary Anderson was the steam reformer test program manager. Richard Boardman provided fluidized bed and steam reforming technical consultation. Doug Marshall, Nick Soelberg, and Steve Bates designed and directed the steam reformer tests. Curtis St. Michel directed the team that designed and operated the process logic controller hardware, software, and related instrumentation. Duane Siemer designed and performed onsite analyses for process control and posttest laboratory analyses. Brad Ward performed onsite data and sample analyses and posttest sample management.

Personnel from ThermoChem Waste Remediation, LLC, who provided valuable consultation and test observation, included Ravi Chandran and Lee Rockvam. 


\section{CONTENTS}

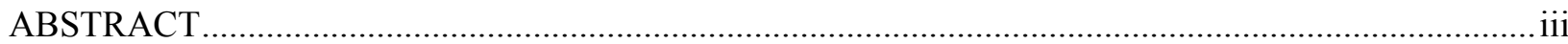

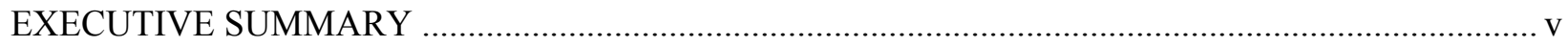

Test Accomplishments, Conclusions, and Recommendations .......................................... v

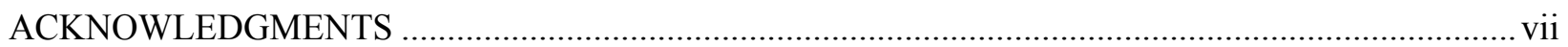

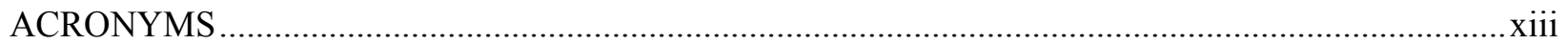

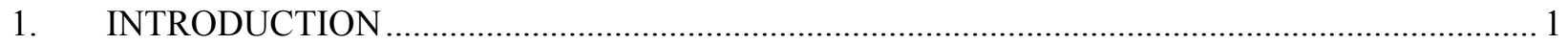

1.1 Purpose

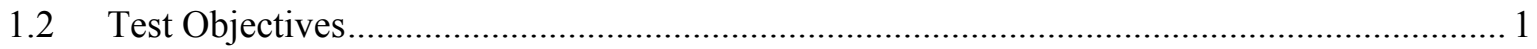

2. FLUIDIZED BED TEST SYSTEM DESCRIPTION …........................................................ 3

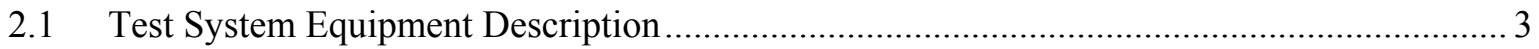

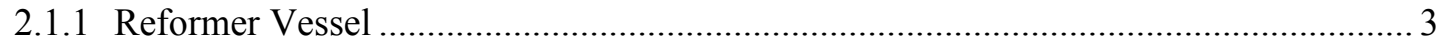

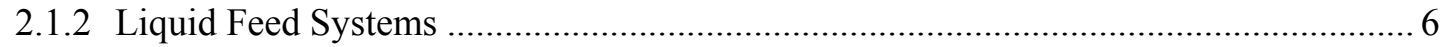

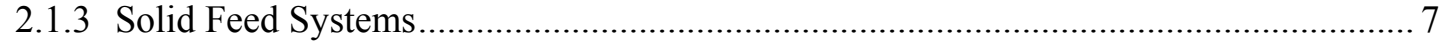

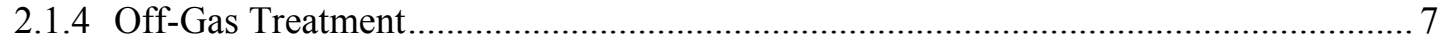

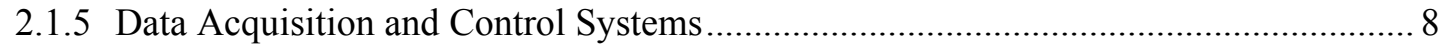

2.2 Steam Reforming Theory and Experimental Approach .................................................. 8

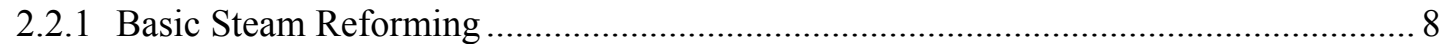

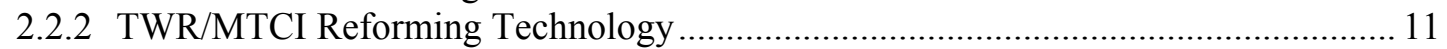

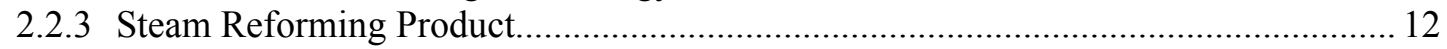

3. MEASUREMENTS, SAMPLE COLLECTION, AND SAMPLE ANALYSIS............................. 13

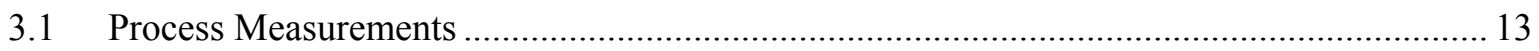

3.2 Continuous Off-gas Composition Monitoring ............................................................ 13

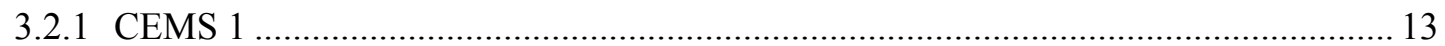

3.2.2 Partial Quench Outlet and Carbon Bed Inlet Hg CEM............................................... 16

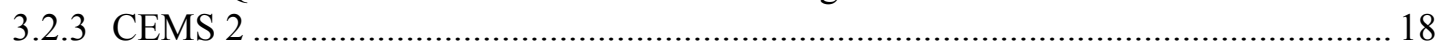

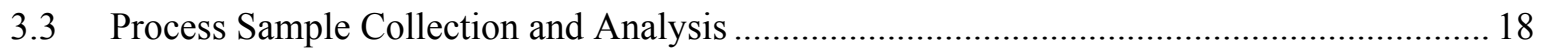

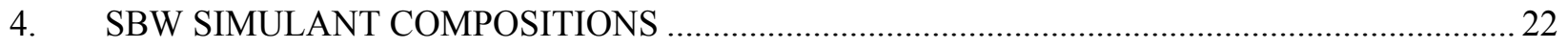

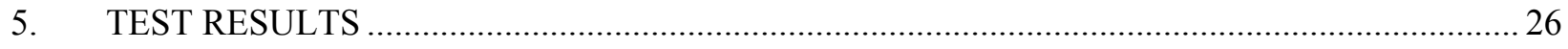

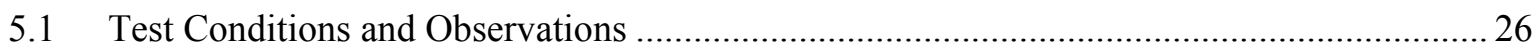




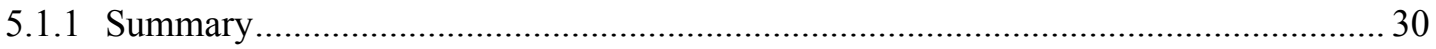

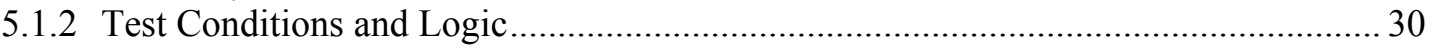

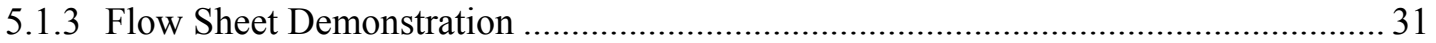

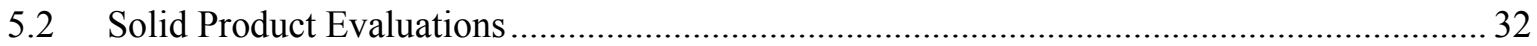

5.2.1 Solid Product Distribution and Mass Balance Closure ............................................... 33

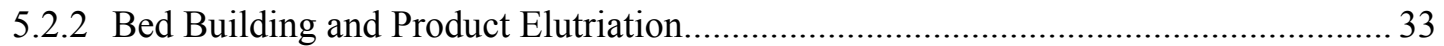

5.2.3 Solid Product Characterization and Particle Size ....................................................... 34

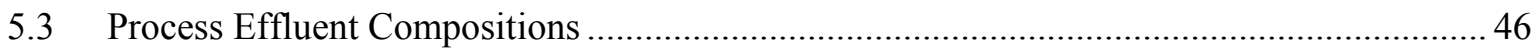

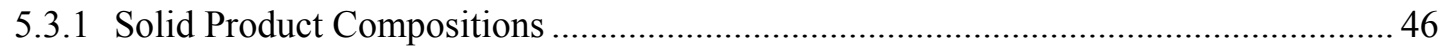

5.3.2 Scrub Solution and CEMS Condensate Compositions …............................................. 46

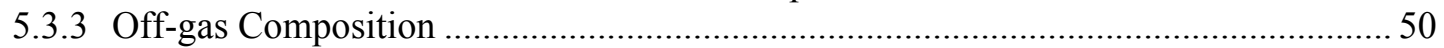

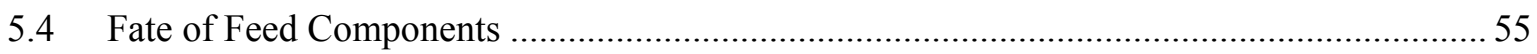

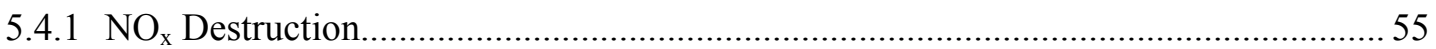

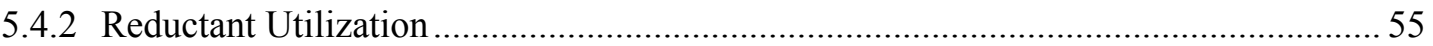

5.4.3 Product Elemental Distribution and Mass Balance Closure .......................................5 59

5.4.4 Off-gas Mercury Concentrations and Emissions Control...........................................62 62

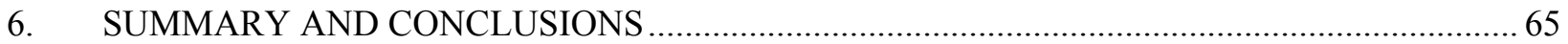

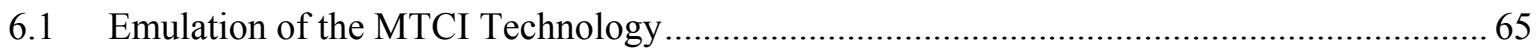

6.2 Phase 2 Test Accomplishments, Conclusions, and Recommendations................................. 66

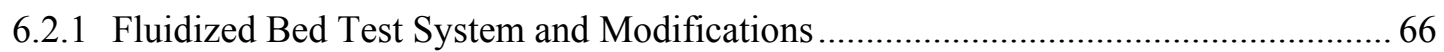

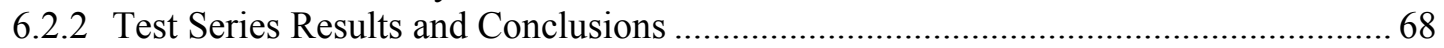

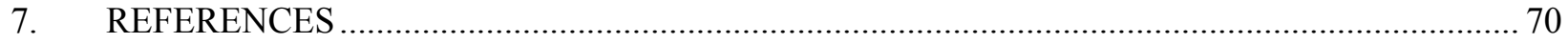

\section{APPENDICES}

\section{FIGURES}

2-1. $\quad$ Fluidized bed test system at the SAIC STAR Center ............................................................ 4

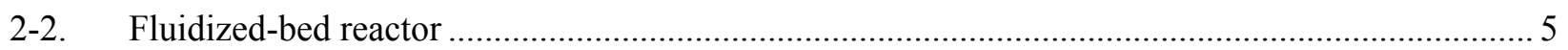

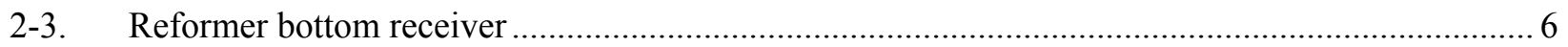

3-1. CEMS 1 for steam reformer off-gas measurements at the filter outlet sample location,

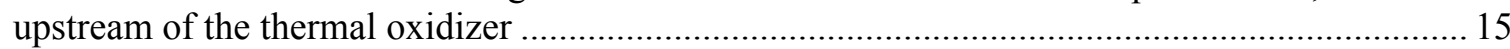

3-2. PSA analytical Hg CEMS, with dual sampling and conditioning systems ............................... 17 
3-3. CEMS 2 for steam reformer off-gas measurements downstream of the carbon bed

5.1-1. Operating conditions for the parametric test series............................................................ 28

5.2-1. Continuously measured in situ bed depth and mass for the first TWR test week........................ 35

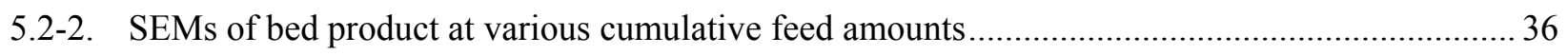

5.2-3. Mass and harmonic mean bed product particle diameter versus cumulative SBW fed ................. 38

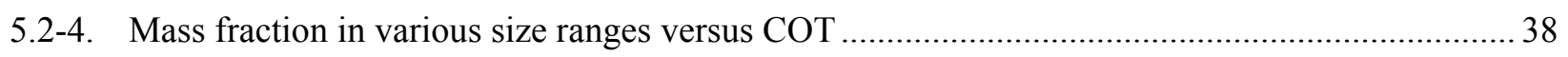

5.2-5. Optical microscope photographs (backlit) of bed product particles from Sample 153

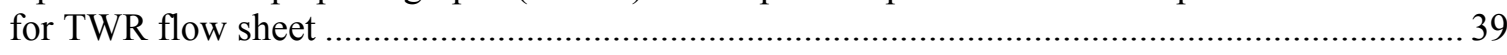

5.2-6. SEMs of TWR flow sheet bed product, sample 197 (Test condition 5.4) .................................. 40

5.2-7. SEMs of cyclone material, sample 125 (Test Condition 5.3), from the TWR test series. ............. 42

5.2-8. SEMs of filter material, sample 160 (Test Condition 5.4), from the TWR test series................... 43

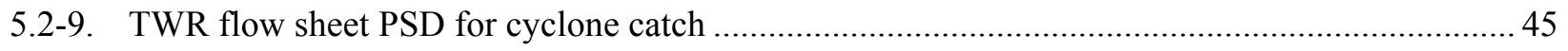

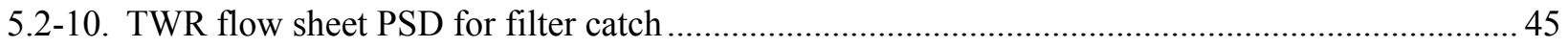

\section{TABLES}

2-1. Waste reforming physical and chemical reactions summary .................................................. 9

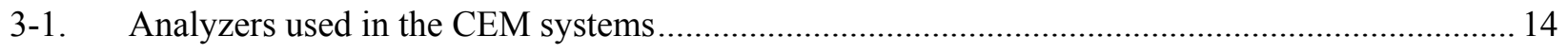

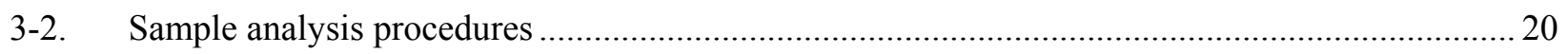

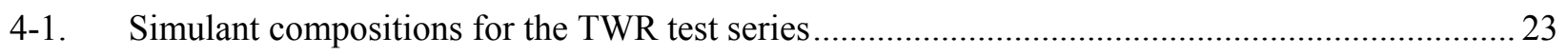

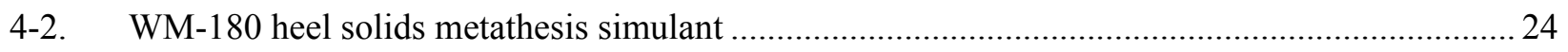

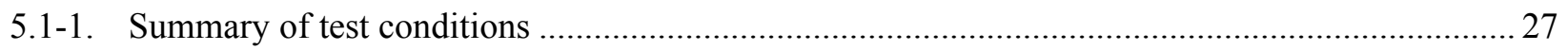

5.2-2. Bed product bulk and particle densities for the TWR test series ............................................. 41

5.3-1. Calculated solid product distribution and composition based on chemical equilibrium calculations

5.3-2. Elemental composition of the bed product for the TWR test series ......................................... 48

5.3-3. Elemental composition of the cyclone and filter catch samples for the TWR test series .............. 48

5.3-4. Scrub solution and CEMS condensate composition for the TWR test series ............................. 49 
5.3-5. Off-gas composition (wet basis) at the outlet of the heated filter for the TWR test series

5.3-6. Off-gas composition downstream of the oxidizer and scrubber for the TWR test series 56

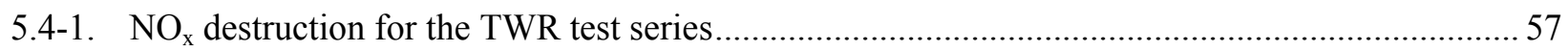

5.4-2. Carbon mass distribution and balance for the TWR test series week 2 ..................................... 59

5.4-3. Elemental distributions and mass balance closure for the TWR test series ................................. 61

5.4-4. Hg speciation, concentrations, mass balance closure, and carbon bed sorption efficiency

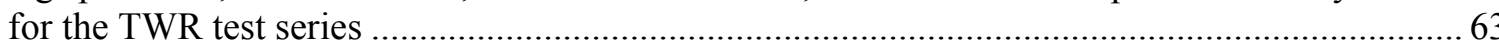

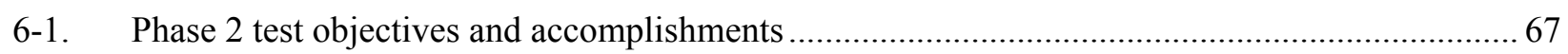




\section{ACRONYMS}

ALD Analytical Laboratory Department

ASTM American Society of Testing and Materials

CAI California Analytical Instruments

CEMS continuous emissions monitoring system

$\mathrm{CF} \quad$ cumulative feed

CFR Code of Federal Regulations

COT cumulative operating time

CST continuous sampling train

CVAA cold vapor atomic absorption

DOE Department of Energy

DOT Department of Transportation

DUV dispersive ultraviolet

EPA Environmental Protection Agency

FID flame ionization detector

GAC granular activated carbon

GFC gas filter correction

GUI graphical user interface

HMI human-machine interface

HMPD harmonic mean particle diameter

HWC Hazardous Waste Combustor

IC ion chromatography

ICP-AES inductively-coupled plasma atomic emission spectroscopy

INEEL Idaho National Engineering and Environmental Laboratory

INTEC Idaho Nuclear Technology and Engineering Center

IPA isopropyl alcohol

IRC INEEL Research Center

LRB Laboratory Record Book

MACT maximum achievable control technology

MMPD mass mean particle diameter

MTCI Manufacturing Technology Conversion International

MTEC maximum theoretical emission concentration

NAR nozzle atomizing ratio

NDIR nondispersive infrared 
PLC process logic controller

PM particulate matter

PSD particle size distribution

QA/QC quality assurance/quality control

RCRA Resource Conservation and Reclamation Act

RFA/COC request for analysis/chain of custody

RPD relative percent difference

SAIC Science Applications International Corporation

SBW sodium-bearing waste

SEM scanning electron micrograph or microscope

STAR Science and Technology Applications Research

THC total hydrocarbon

TRA Test Reactor Area

TWR ThermoChem Waste Remediation, LLC

UDS undissolved solids

WIPP Waste Isolation Pilot Plant

WIR waste incidental to reprocessing 


\section{Phase 2 TWR Steam Reforming Tests for Sodium-Bearing Waste Treatment}

\section{INTRODUCTION}

The Idaho Nuclear Technology and Engineering Center (INTEC) was home to nuclear fuel reprocessing activities for decades until recovery of unspent uranium was halted in the 1990s. As a result of the reprocessing activities, INTEC has accumulated about one million gallons of acidic, radioactive, sodium-bearing waste (SBW). To date, the raffinates from reprocessing activities and much of the SBW have been calcined into a powder for storage pending final treatment. Further treatment of the SBW inventory is on hold pending a review and determination of the most appropriate treatment method. Steam reforming is a candidate technology being investigated for treatment of the SBW into a road ready waste form that can be shipped to the Waste Isolation Pilot Plant (WIPP) in New Mexico for interment.

Calcination of the SBW, which resulted in visibly brown emissions of nitrogen oxides $\left(\mathrm{NO}_{\mathrm{x}}\right)$, required the recycle of high-mercury scrub solutions to the waste tanks and did not employ maximum achievable control technology (MACT) to control gaseous emissions. Any alternative technologies that may be deployed for the treatment of SBW must be capable of meeting air quality standards and emission limits, and avoid generation of secondary wastes that cannot be readily treated and dispositioned with the treated SBW.

A proprietary steam reforming technology, patented by Manufacturing Technology Conversion International (MTCI) and licensed to ThermoChem Waste Remediation (TWR), was demonstrated on a WM-180 sodium-bearing waste (SBW) simulant in December 2002 using government equipment in Idaho Falls, Idaho (Marshall 2003a). This demonstration showed that SBW could be successfully converted into an alkali carbonate powder without serious agglomeration, but the emphasis was on process viability and reliability rather than on production and optimization.

\subsection{Purpose}

The purpose of these optimization tests was to push the envelope of operating parameters to determine how product quality (i.e., low carbon content) and production rate are affected by changes in processing temperature, and the type and quantity of additives (reductants). In addition to seeking more optimum performance of the steam reformer, additional off-gas treatment and monitoring equipment had been installed to demonstrate the ability to achieve MACT compliance with the steam reformer with regard to the capture of mercury and the destruction of carbon monoxide and other products of incomplete combustion.

\subsection{Test Objectives}

Test objectives were defined to provide data on the efficacy of steam reforming as a treatment for SBW. The quantifiable test objectives are prioritized in order of their importance as:

- $\quad$ Determine suitable fluidized-bed operating parameters for the treatment of simulated WM-180

SBW supernate and suspended solids that will:

- $\quad$ Achieve $90 \%$ reduction in NOx evolution relative to nitrates in the feed

- $\quad$ Four times the SBW processing rate relative to previous tests (i.e., $\geq 4 \mathrm{~L} / \mathrm{hr}$ ) (Marshall et al. 2003). 
- $\quad$ Maintain a stable bed with minimal addition of bed seed particles

- $\quad$ Reduce/minimize carryover of unreacted carbon and carbonaceous compounds in the product

- Determine the combustion efficiency of the thermal oxidizer and characterize the outlet gas composition

- Determine the control efficiencies for $\mathrm{Hg}$ and $\mathrm{Cl}$ in the wet scrubber and granulated activated carbon $(\mathrm{GAC})$ bed

- $\quad$ Determine the fate of feed constituents and additives, including the halides, volatile heavy metals, cesium, etc.

- Characterize solid product composition, quantity, and handling properties. 


\section{FLUIDIZED BED TEST SYSTEM DESCRIPTION}

A simplified process flow and instrumentation diagram of the fluidized bed test system at the SAIC STAR Center is shown in Figure 2-1. The primary components of the test system include the reformer vessel, product collection systems, feed systems, off-gas control system, and process logic controller (PLC) system. The test system covers a footprint of about $40 \times 40$ feet. All wetted components are constructed from corrosion-resistant materials. Equipment and piping are fabricated from 300 -series stainless steel except for the reformer vessel, which is fabricated from Inconel $800 \mathrm{H}$. The system can be manually controlled or automatically controlled using a PLC system with multiple human-machine interface stations.

\subsection{Test System Equipment Description}

The reformer vessel is the primary component of the test system. The other components (the product collection systems, the feed systems, the off-gas control system, and the PLC system) are ancillary components necessary for operation.

\subsubsection{Reformer Vessel}

The fluidized-bed steam reformer (shown in Figure 2-2) was made of Inconel $800 \mathrm{H}$ pipe to tolerate operating conditions, including temperatures that could reach $800^{\circ} \mathrm{C}$, oxidizing or reducing conditions, and the presence of corrosive or hazardous materials. The main features of the fluidized bed vessel were the fluidized-bed section, freeboard (particle disengaging) section, and gas distributor, through which the fluidizing gas enters the vessel.

The fluidized-bed section was 6 inches in diameter and 30 inches tall, with 6-inch 150\# flanges on either end. Numerous ports in the bed section provided the versatility and instrumentation required to conduct research and development activities. The ports were arranged in three vertical columns, 120 degrees apart, to accommodate external radiant heaters and to prevent direct impingement of any feed material on another port.

Four of the ports were constructed of 1.5-inch, schedule 40 pipe that entered the bed section at 60 degree angles (relative to horizontal) and were located at 4, 13, and 22 inches above the bottom of the bed section. These ports were angled to reduce the accumulation of stagnant bed and to facilitate clearing. Solid additives have traditionally been introduced through these ports via pneumatic and auger conveyances. Two 2 -inch schedule 40 ports were located at 4 and 13 inches above the bottom of the bed section. These ports were horizontal and intended for introduction of liquids and/or gases. The atomizing feed nozzle was installed in the lower of these two ports. Additional ports were provided for thermocouple penetrations at 6-inch intervals over the length of the bed section, and a pressure port located 12 inches above the lower flange of the bed section. The pressure port was used to monitor the differential pressure across a portion of the fluid bed as a measure of the average fluidized-bed density.

The bed section was bolted below a freeboard section that was 12 inches in diameter and 5 feet tall. The two sections were coupled with a concentric $12 \times 6$-inch reducer welded to the freeboard. The freeboard section was externally heated with radiant heaters designed to fit the contour of the vessel and fit between the instrument penetrations. 


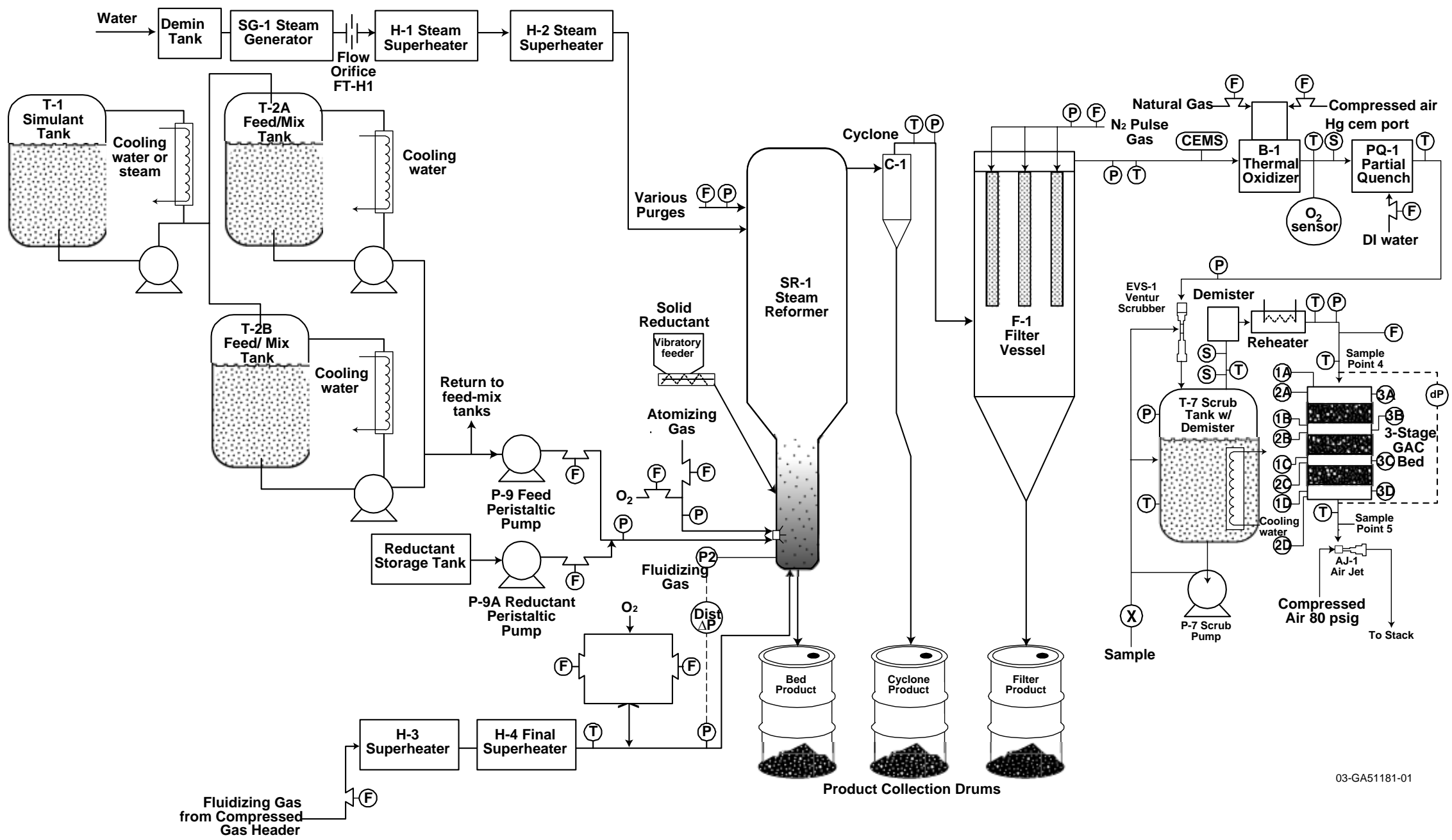

Figure 2-1. Fluidized bed test system at the SAIC STAR Center. 

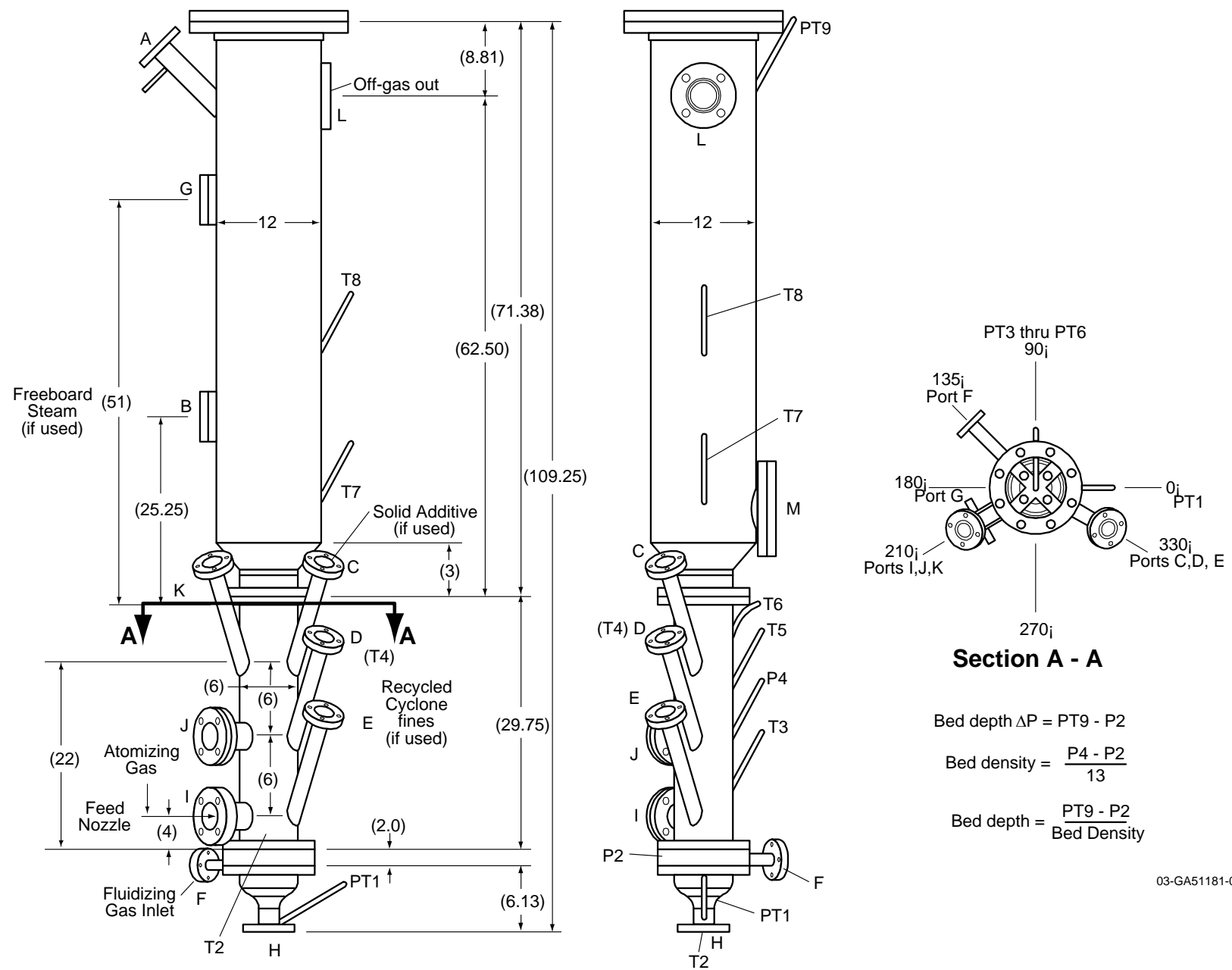

Figure 2-2. Fluidized-bed reactor.

The reformer bottom receiver (Figure 2-3) was a 6-inch, 150\# blind flange that had been drilled and milled to provide an eccentric 1.9-inch-diameter bottom drain (OD of a nominal 1.5-inch pipe), a sample riser (3/4-inch tubing extending 2 inches above the distributor), a thermocouple port, and an auxiliary port with a 0.25 -inch opening. The auxiliary port can be fitted with a rudimentary feed nozzle comprising concentric $1 / 4$ - and $1 / 8$-inch tubing, with liquids fed through the smaller tube and the atomizing gas through the annulus between the tubes.

The distributor (Figure 2-4) used during conduct of the test was a 4-inch-diameter sparge ring made of $1 / 2$-inch, 300-series stainless steel tubing mounted in a 316 stainless steel, 6-inch, 150\# flange. Several orifices were drilled into the ring to distribute the fluidizing gas. Half of the orifices oriented radially inward at a downward angle of 45 degrees off vertical, while the other half were oriented radially outward at a downward angle of 30 degrees off-vertical. The ring fully encompassed all of the penetrations/ports from the receiver. The distributor flange was provided with a pressure port through the side of the flange for measuring distributor, total bed, and bed density differential pressures and absolute reactor pressure. 


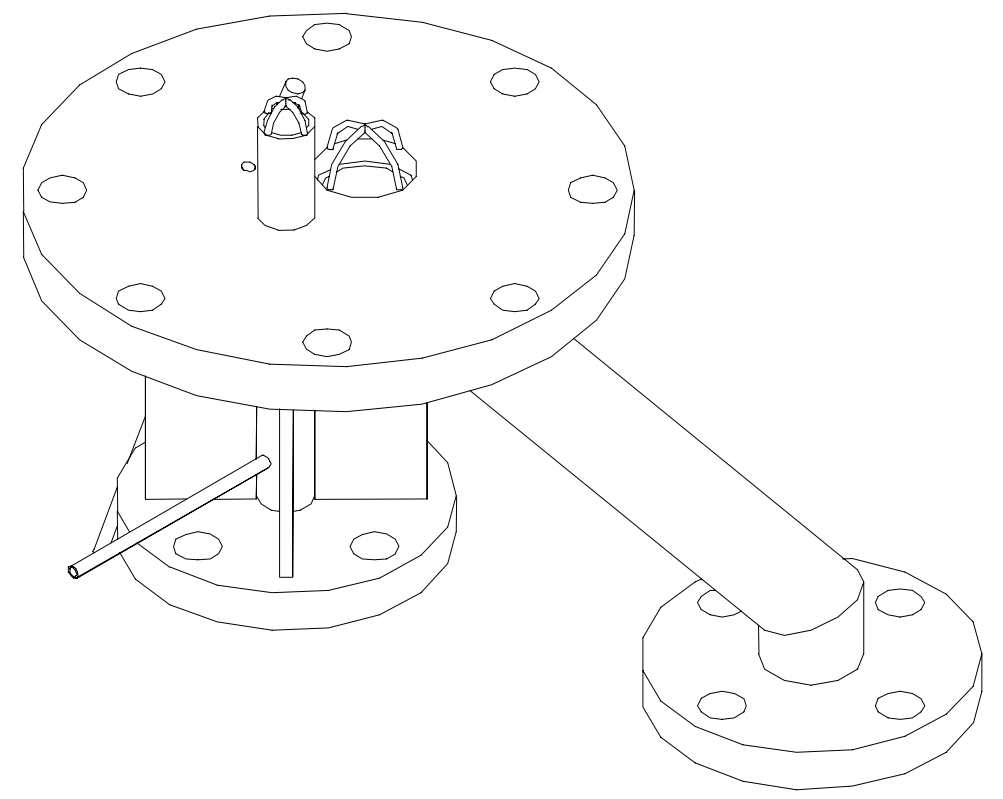

Figure 2-3. Reformer bottom receiver.

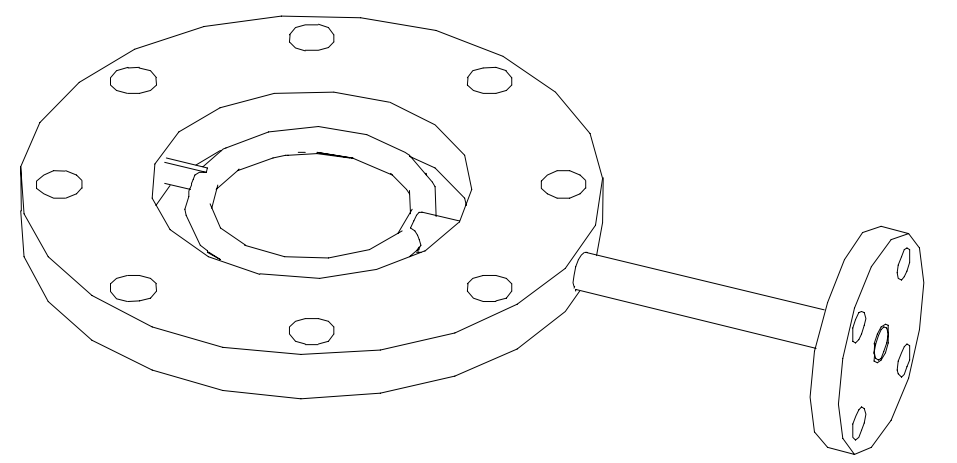

Figure 2-4. Ring Distributor.

\subsubsection{Liquid Feed Systems}

Feed systems included the simulant hold/makeup tank, two day-tanks, and an IPA system. The simulant tank was designed to hold 800 liters of solution; the day tanks were designed for 200 liters to accommodate feed rates up to 8 liters/hour. All three tanks are equipped with variable speed agitators and a recirculation/transfer pump to ensure that the solutions are fully mixed and undissolved solids remain suspended and uniformly blended.

In the demonstration conducted in December 2002, the liquid reductant additive was blended with the SBW simulant in the feed tanks and pumped to the process via a peristaltic pump that pulled a slip stream off of the recirculation line. For the Phase 2 tests, the feed system was retrofitted with a separate peristaltic pump and coriolis mass flow meter for the liquid reductant so that the SBW and reductant blend ratios could be easily varied and to mimic what is envisioned for a full-scale treatment facility. The two feed streams were combined and passed through an in-line static mixer just before being atomized in the feed nozzle. 
Feed plugging from undissolved solids in the SBW simulant and the liquid reductant required that the in-line mixer be removed for the majority of the testing. Mixing that occurred at the atomizing nozzle was considered adequate to get valid test results even though the SBW simulant and reductant did not completely mix in the line before the feed nozzle.

Most of the testing was completed using a Spraying Systems Co. extended nozzle body with a 60100 liquid nozzle and an 120 air cap. The liquid orifice was 0.060 inches in diameter and the air cap provided a 0.010-inch-wide annulus around the orifice through which the atomizing gas was passed. The extended nozzle body was incorporated into a customized water jacket to prevent the nozzle from overheating in the reformer.

An alternate feed nozzle was made from a 1/8-inch tube nested inside a 1/4-inch tube. The feed liquid would pass through the smaller tube, and the atomizing gas through the annulus between the tubes. The assembly was passed through the auxiliary port in the reformer receiver. The advantage was that this feed nozzle could be removed and re-installed without draining the bed. The disadvantage was that it had not been previously tested in the system, and the annulus was much larger than the spraying system nozzle configuration. There is some uncertainty about the ability to adequately atomize the feed without reducing the annular cross-sectional area.

\subsubsection{Solid Feed Systems}

Solid additives were augured from Acrison weight-loss feeders into the process. The bed media was added via two valves that formed a lock hopper and had sufficient density that it subsided into the fluidized bed without further assistance. The solid reductant used in the December 2002 tests was available for use, but was not used because it was considered not necessary. A system was provided whereby the solids would be fed to the reformer via a computer-controlled lock hopper into a watercooled auger.

\subsubsection{Off-Gas Treatment}

Product fines and process gases exited the freeboard section and passed through a 5-inch-diameter cyclone separator to remove most of the particles in excess of $15 \mu \mathrm{m}$. The off-gas was subsequently filtered in a vessel with seven 2.5-inch-diameter, 24-inch long, sintered-metal filters with a nominal pore size of $2 \mu \mathrm{m}$. The cyclone catch freely dropped from the cyclone into a dedicated drum that was lightly purged to keep the product dry. The filter catch was periodically dislodged from the filter candles via gas pulses that were introduced into the throat of the filter candles. The filter catch was also collected in a purged product drum.

Filtered gases were passed into a natural gas-fired thermal oxidizer, operated at $1,000^{\circ} \mathrm{C}$, where they were combined with air to oxidize the hydrogen, carbon monoxide, methane, and other hydrocarbons resulting from the decomposition and reformation of the liquid and solid reductants. The oxidized gases were quenched with a water spray and scrubbed with a venturi scrubber. The quench exit temperature and the scrub solution temperatures are controlled to maintain scrub solution levels in the scrubber relatively constant.

The scrubbed off-gases were subsequently passed through a divided column of granular, sulfurimpregnated, activated carbon to capture the mercury emissions and prove that technology for mercury capture and removal. 
Off-gas treatment equipment downstream of the off-gas filter (i.e., thermal oxidizer, quench, scrubber, and activated carbon column) were added for data generation purposes. They were not required to be in place for emission control.

\subsubsection{Data Acquisition and Control Systems}

The test system is equipped with an automated process logic controller (PLC) system. The PLC uses Rockwell hardware and software to monitor and control operation of the process from two or more human-machine interface (HMI) personal computer workstations, located near the process equipment. Additional workstations are available, one for use at the CEMS panels, and one for monitoring only (no control allowed), located in an office area for non-operating personnel. The process control functions include automated control of valve and pump sequences for the feed system, automated control of all total gas flow rates, selectable input temperature control for the fluidized bed vessel, vacuum control of the system based on the pressure in the reformer, and limited control of the CEMS. The graphical user interface (GUI) for the system shows the status of the components, provides a control interface for the operator and displays readings from all the instrumentation in numeric and trend form.

The data acquisition system utilizes Rockwell software integrated with the PLC and a Sequel database for electronically archiving data as it is monitored. Each record in the database includes the tag name for the data-point, description, value, units, and time-stamp. Analog values from the system are archived once per second, and discrete values are archived on change of state. The process monitoring workstation in the office area is equipped with a Web interface to the database for access to the archived data during the tests. The Web interface provides data access from the database and averages at userdefined intervals in Microsoft Excel spreadsheets.

\subsection{Steam Reforming Theory and Experimental Approach}

\subsubsection{Basic Steam Reforming}

Carbonaceous materials such as biomass, plastics, petroleum fractions, etc., react with steam at high temperatures, decomposing into hydrogen, carbon monoxide, carbon dioxide, and chemical radicals that can recombine to form a host of hydrocarbons (e.g., methane, aromatic compounds, etc.). Steam reforming is a leading candidate for producing hydrogen from agricultural residues and post-consumer products.

The ability to produce carbon dioxide, hydrogen, methane, and reactive radicals is an asset when considering treatment of alkali nitrate waste solutions. The high temperatures, steam, and reactive gases facilitate the denitration of alkali nitrates and the reduction of $\mathrm{NO}_{\mathrm{x}}$ to nitrogen and carbon oxides. A dry alkali carbonate product is formed in the process, which can be containerized for immediate disposal or further conditioning as necessary.

The extent of $\mathrm{NO}_{\mathrm{x}}$ reduction depends on the concentrations of hydrogen and methane (and their associated radicals) that are produced in the steam reformer, and the presence of metal compounds that catalyze the formation of hydrogen and methane or the reaction between them and $\mathrm{NO}_{\mathrm{x}}$ species. Known catalytically active metals employed in steam reforming processes are nickel, copper, and zinc (MagriniBair 2002, Ogden). Other important metals are magnesium, which stabilizes the nickel metal, and potassium that is often used to inhibit coking of the catalyst. The Fischer-Tropsch reaction reacts carbon monoxide and hydrogen to produce methane in the presence of a Group VIII catalyst, such as iron and nickel. All of these metals are present in the SBW and promote the formation of hydrogen by the watergas shift reactions and the production of methane via methanation.

A summary of potential reaction mechanisms is given in Table 2-1. 
Table 2-1. Waste reforming physical and chemical reactions summary.

\begin{tabular}{|c|c|c|}
\hline Process Step & General Reaction Examples & Comments \\
\hline $\begin{array}{l}\text { Solution evaporation/ } \\
\text { particles drying }\end{array}$ & Waste sol'n (liquid) $\rightarrow \mathrm{H}_{2} \mathrm{O}$ (gas) $+\mathrm{NaNO}_{3}, \mathrm{Al}\left(\mathrm{NO}_{3}\right)_{3}$, etc. & $\begin{array}{l}\text { Commences in liquid droplet, continues in particle film, except } \\
\text { at high-temperatures/high-heating rates when evaporation } \\
\text { occurs above the solid-gas boundary layer. Rapid evaporation } \\
\text { of spray droplets results in submicron size particles. }\end{array}$ \\
\hline $\begin{array}{l}\text { Solid salt thermal } \\
\text { dissociation/ } \\
\text { decomposition }\end{array}$ & $\begin{array}{l}2 \mathrm{Al}\left(\mathrm{NO}_{3}\right)_{3}(\mathrm{~s}) \rightarrow \mathrm{Al}_{2} \mathrm{O}_{3}(\mathrm{~s})+6 \mathrm{NO}_{2}(\mathrm{~g})+1 \frac{1}{2} \mathrm{O}_{2}(\mathrm{~g}) \\
2 \mathrm{NaNO}_{3}(\mathrm{~s}) \rightarrow \mathrm{Na}_{2} \mathrm{O}(\mathrm{s})+2 \mathrm{NO}_{2}(\mathrm{~g})+1 / 2 \mathrm{O}_{2}(\mathrm{~g}) \\
\mathrm{Na}_{2} \mathrm{CO}_{3}(\mathrm{~s}) \leftrightarrow \mathrm{Na}_{2} \mathrm{O}(\mathrm{s})+\mathrm{CO}_{2}(\mathrm{~g}) \\
\mathrm{Na}_{2} \mathrm{CO}_{3}(\mathrm{~s})+\mathrm{H}_{2} \mathrm{O}(\mathrm{g}) \leftrightarrow 2 \mathrm{NaOH}(\mathrm{l})+\mathrm{CO}_{2}(\mathrm{~g})\end{array}$ & $\begin{array}{l}\text { Transition metal nitrates typically rapidly dissociate below } \\
400^{\circ} \mathrm{C} \text {. Alkali metal nitrates typically denitrate slowly, and can } \\
\text { persist to temperatures up to } 600^{\circ} \mathrm{C} \text {. Molten alkali hydroxides } \\
\text { can lead to dissolution of other salts and bed agglomeration, } \\
\text { which is not desirable in a fluidized bed. }\end{array}$ \\
\hline $\begin{array}{l}\text { Organic compound } \\
\text { depolymerization/ } \\
\text { devolatilization/ } \\
\text { char formation }\end{array}$ & $\begin{array}{l}\mathrm{C}_{\mathrm{m}} \mathrm{H}_{\mathrm{n}}(\mathrm{s}) \rightarrow \operatorname{char}(\mathrm{s})+\operatorname{tars} / \text { oils, } \mathrm{C}_{\mathrm{x}} \mathrm{H}_{\mathrm{y}}(\mathrm{g}) \\
\mathrm{C}_{1} \mathrm{H}_{\mathrm{m}} \mathrm{O}_{\mathrm{n}} \rightarrow \operatorname{char}(\mathrm{s})+\operatorname{tars} / \text { oils, } \mathrm{C}_{\mathrm{x}} \mathrm{H}_{\mathrm{y}}(\mathrm{g})+\mathrm{H}_{2}, \mathrm{OH}, \mathrm{H}_{2} \mathrm{O}(\mathrm{g})\end{array}$ & $\begin{array}{l}\text { Organic evolution rates and speciation depends on hydrocarbon } \\
\text { functional groups, particle heating rates, reactor temperature and } \\
\text { particle residence time. Light gases and tars evolve } \\
\text { competitively. }\end{array}$ \\
\hline $\begin{array}{l}\text { Solid state organic } \\
\text { redox reactions }\end{array}$ & $\begin{array}{l}2 \mathrm{NaNO}_{3}(\mathrm{~s})+\mathrm{C}(\mathrm{s}) \text { or carbon source }(\mathrm{s}) \\
\rightarrow \mathrm{Na}_{2} \mathrm{CO}_{3}(\mathrm{~s})+\mathrm{N}_{2}(\mathrm{~g}) \\
\text { @ solid waste-char or carbon particle boundary [or] } \\
\text { @ solid waste-organic compound/char in dehydrated droplets or } \\
\text { solid layer on an existing particle }\end{array}$ & $\begin{array}{l}\text { Nitrate-organic reduction occurs spontaneously at } 250-350^{\circ} \mathrm{C} \\
\text { and typically propagates as a deflagration through the remaining } \\
\text { unreacted solid reactant mixture. A detonation is possible if } \\
\text { sufficient reactant mixture is allowed to build up at a } \\
\text { temperature less than the reaction initiation threshold and } \\
\text { subsequently ignited when heat dissipation is inhibited. }\end{array}$ \\
\hline $\begin{array}{l}\text { Solid state inorganic } \\
\text { reactions }\end{array}$ & $\begin{array}{l}2 \mathrm{NaNO}_{3}(\mathrm{~s})+\mathrm{Al}_{2} \mathrm{O}_{3}(\mathrm{~s}) \rightarrow 2 \mathrm{NaAlO}_{2}(\mathrm{~s})+2 \mathrm{NO}_{2}(\mathrm{~g})+1 / 2 \mathrm{O}_{2}(\mathrm{~g}) \\
\mathrm{Na}_{2} \mathrm{O}(\mathrm{s})+\mathrm{Al}_{2} \mathrm{O}_{3}(\mathrm{~s}) \rightarrow 2 \mathrm{NaAlO}_{2}(\mathrm{~s}) \\
\mathrm{Na}_{2} \mathrm{O}(\mathrm{s})+\mathrm{SiO}_{2}(\mathrm{~s}) \rightarrow \mathrm{Na}_{2} \mathrm{SiO}_{3}(\mathrm{~s})\end{array}$ & $\begin{array}{l}\text { Silica is present as a contaminant in the makeup water and in the } \\
\text { simulated heel solids. }\end{array}$ \\
\hline $\begin{array}{l}\text { Heterogeneous carbon } \\
\text { gasification reactions }\end{array}$ & $\begin{array}{l}\text { 1. } \mathrm{H}_{2} \mathrm{O}(\mathrm{g})+\mathrm{C}(\mathrm{s}) \rightarrow \mathrm{CO}(\mathrm{g})+\mathrm{H}_{2}(\mathrm{~g}) \\
\text { 2. } \mathrm{CO}_{2}(\mathrm{~g})+\mathrm{C}(\mathrm{s}) \rightarrow 2 \mathrm{CO}(\mathrm{g}) \\
\text { 3. } \mathrm{O}_{2}(\mathrm{~g})+2 \mathrm{C}(\mathrm{s}) \rightarrow 2 \mathrm{CO}(\mathrm{g}) \\
\text { 4. } \mathrm{NO}_{2}(\mathrm{~g})+\mathrm{C}(\mathrm{s}) \rightarrow \mathrm{CO}(\mathrm{g})+\mathrm{NO}(\mathrm{g})\end{array}$ & $\begin{array}{l}\text { Gasification to CO is typically endothermic. } \\
\text { Eq. (3) is negligible under fuel-rich, steam reforming conditions. } \\
\text { Eq. (4) is slower than Eq. (1) and (2) and may not be significant. } \\
\text { Oxides and carbonates in the solids can catalyze char reactions. }\end{array}$ \\
\hline $\begin{array}{l}\text { Heterogeneous } \\
\text { inorganic reactions }\end{array}$ & $\begin{array}{l}\mathrm{Na}_{2} \mathrm{O}(\mathrm{s})+\mathrm{NO}_{2}(\mathrm{~g})+\mathrm{NO}(\mathrm{g}) \rightarrow 2 \mathrm{NaNO}_{3}(\mathrm{~s}) \\
\mathrm{Na}_{2} \mathrm{O}(\mathrm{s})+\mathrm{CO}_{2}(\mathrm{~g}) \rightarrow \mathrm{Na}_{2} \mathrm{CO}_{3}(\mathrm{~s}) \\
\mathrm{Na}_{2} \mathrm{O}(\mathrm{s})+\mathrm{H}_{2} \mathrm{O}(\mathrm{g}) \rightarrow 2 \mathrm{NaOH}(\mathrm{l}) \\
\mathrm{Na}_{2} \mathrm{O}(\mathrm{s})+2 \mathrm{HCl}(\mathrm{g}) \rightarrow 2 \mathrm{NaCl}(\mathrm{s})+\mathrm{H}_{2} \mathrm{O}(\mathrm{g}) \\
\mathrm{CaO}(\mathrm{s})+2 \mathrm{HCl}(\mathrm{g}) \rightarrow \mathrm{CaCl}_{2}(\mathrm{~s})+\mathrm{H}_{2} \mathrm{O}(\mathrm{g}) \\
2 \mathrm{NaOH}(\mathrm{l})+\mathrm{Al}_{2} \mathrm{O}_{3}(\mathrm{~s}) \rightarrow 2 \mathrm{NaAlO}_{2}(\mathrm{~s})+\mathrm{H}_{2} \mathrm{O}(\mathrm{g}) \\
2 \mathrm{NaOH}(\mathrm{l})+\mathrm{SiO}_{2}(\mathrm{~s}) \rightarrow \mathrm{Na}_{2} \mathrm{SiO}_{3}(\mathrm{~s})+\mathrm{H}_{2} \mathrm{O}(\mathrm{g})\end{array}$ & $\begin{array}{l}\text { Product nitration, carbonate formation, and hydration are all } \\
\text { possible. Nitration occurs at } \mathrm{T}<400^{\circ} \mathrm{C} \text {. Carbonate formation } \\
\text { occurs at } \mathrm{T}<800^{\circ} \mathrm{C} \text {. Hydration produces a molten phase of } \\
\text { alkali metals capable of dissolving other product solids and } \\
\text { causing agglomerations. }\end{array}$ \\
\hline
\end{tabular}


Table 2-1. Waste reforming physical and chemical reactions summary (continued).

\begin{tabular}{|c|c|c|}
\hline Process Step & General Reaction Examples & Comments \\
\hline $\begin{array}{l}\text { Gaseous hydrocarbon } \\
\text { chemistry }\end{array}$ & $\begin{array}{l}\text { 1. } \mathrm{CO}+\mathrm{H}_{2} \mathrm{O} \leftrightarrow \mathrm{CO}_{2}+\mathrm{H}_{2} \\
\text { 2. } \mathrm{CO}+4 \mathrm{H}_{2} \leftrightarrow \mathrm{CH}_{4}+4 \mathrm{OH} \\
\text { 3. } \mathrm{H}_{2} \mathrm{O} \leftrightarrow \mathrm{H}+\mathrm{OH}^{-} \\
\text {4. } \mathrm{CO}+\mathrm{OH} \rightarrow \mathrm{CO}_{2}+\mathrm{H} \\
\text { 5. } \mathrm{H}_{2} \leftrightarrow 2 \mathrm{H} \\
\text { 6. } \mathrm{H}+\mathrm{H}_{2} \mathrm{O} \leftrightarrow \mathrm{H}_{2}+\mathrm{OH} \\
\text { 7. } \mathrm{CO}_{2} \leftrightarrow \mathrm{CO}+1 / 2 \mathrm{O}_{2} \\
\text { 8. } \mathrm{C}_{3} \mathrm{H}_{8} \mathrm{O} \rightarrow 2 \mathrm{CH}_{3}+\mathrm{CO}+\mathrm{H}_{2} \\
\text { 9. } \mathrm{CH}_{3}+\mathrm{H}^{\circ} \rightarrow \mathrm{CH}_{4} \\
\text { 10. } 2 \mathrm{CH}_{3}+\mathrm{H}_{2} \rightarrow 2 \mathrm{CH}_{4}\end{array}$ & $\begin{array}{l}\text { 1. Water-gas shift reaction, significant at } \mathrm{T}>600-625^{\circ} \mathrm{C} \text {. } \\
\text { 2. Methanation is generally low. } \\
\text { Hydrogen and carbon give rise to highly reactive hydrogen, } \\
\text { hydroxide, peroxide, and oxygen radicals through the fuel-rich } \\
\text { zone. Such reactions promote ring opening, chain breaking, } \\
\text { hydrogen extraction/substitution reaction, etc. These reactions } \\
\text { are very fast for T }>600-650^{\circ} \mathrm{C} \text { and lead to chain propagation. } \\
\text { Below } 600^{\circ} \mathrm{C} \text {, many radicals terminate and continued reaction is } \\
\text { driven by } \mathrm{OH} \text { radical (e.g., Reaction } 4 \text { ). } \\
\text { Reactions } 8-10 \text { : Significant methane production appears to } \\
\text { proceed from the decomposition of isopropyl alcohol. }\end{array}$ \\
\hline $\begin{array}{l}\text { Gaseous nitrogen } \\
\text { chemistry }\end{array}$ & $\begin{array}{l}\mathrm{CH}_{4}+4 \mathrm{NO}_{2} \rightarrow 4 \mathrm{NO}+\mathrm{CO}_{2}+2 \mathrm{H}_{2} \mathrm{O} \\
\mathrm{CH}_{3}+\mathrm{NO} \rightarrow \mathrm{HCN}+\mathrm{H}_{2} \mathrm{O} \\
\mathrm{CH}_{3}+\mathrm{NO}_{2} \rightarrow \mathrm{CH}_{3} \mathrm{O}+\mathrm{NO} \\
\mathrm{CH}_{2}+\mathrm{NO} \rightarrow \mathrm{HCN}+\mathrm{OH} \\
\mathrm{CH}+\mathrm{NO} \rightarrow \mathrm{HCN}+\mathrm{O} \\
\mathrm{HCN}+\mathrm{OH} \rightarrow \mathrm{HNCO}+\mathrm{H} \\
\mathrm{HCNO}+\mathrm{H} \rightarrow \ldots \mathrm{NH}_{\mathrm{i}}(\mathrm{i}=1,2,3) \\
\mathrm{NH}_{2}+\mathrm{NO} \rightarrow \mathrm{N}_{2}+\mathrm{H}_{2} \mathrm{O} \\
2 \mathrm{CO}+2 \mathrm{NO} \rightarrow \mathrm{N}_{2}+2 \mathrm{CO}_{2} \\
\mathrm{NO}+\mathrm{H}_{2} \rightarrow \mathrm{NH}^{-}+\mathrm{OH}^{-} \\
\mathrm{NH}_{\mathrm{i}=0,1,2}+\mathrm{H}^{-} \rightarrow \mathrm{NH}_{\mathrm{j}=1,2,3}\end{array}$ & $\begin{array}{l}\text { Nitrogen oxides are reduced to cyanides, ammonia, and nitrogen } \\
\text { in the reducing atmosphere. Upward of } 100 \text { significant } \\
\text { elementary-step reactions may be important. } \\
\text { The reactions between the methyl radical and } \mathrm{NO}_{\mathrm{x}} \text { species are } \\
\text { thought to be the dominant mechanisms for } \mathrm{NO}_{\mathrm{x}} \text { destruction } \\
\text { under these reforming conditions, based on prior tests using the } \\
\text { TWR technology by the INEEL and by TWR. }\end{array}$ \\
\hline $\begin{array}{l}\text { Overall IPA-NO } \\
\text { Redox Reactions }\end{array}$ & $\begin{array}{l}2 \mathrm{C}_{3} \mathrm{H}_{8} \mathrm{O}+2 \mathrm{MNO}_{3}+\mathrm{CO}_{2} \rightarrow \mathrm{M}_{2} \mathrm{CO}_{3}+\mathrm{N}_{2}+6 \mathrm{CO}+7 \mathrm{H}_{2}+\mathrm{H}_{2} \mathrm{O} \\
\mathrm{C}_{3} \mathrm{H}_{8} \mathrm{O}+2 \mathrm{MNO}_{3}+\mathrm{CO}_{2} \rightarrow \mathrm{M}_{2} \mathrm{CO}_{3}+\mathrm{N}_{2}+2 \mathrm{CO}+4 \mathrm{H}_{2} \mathrm{O}+\mathrm{C} \\
\mathrm{C}_{3} \mathrm{H}_{8} \mathrm{O}+2 \mathrm{MNO}_{3}+\mathrm{CO}_{2} \rightarrow \mathrm{M}_{2} \mathrm{CO}_{3}+\mathrm{N}_{2}+3 \mathrm{CO}+3 \mathrm{H}_{2} \mathrm{O}+\mathrm{H}_{2} \\
\mathrm{C}_{3} \mathrm{H}_{8} \mathrm{O}+2 \mathrm{MNO}_{3} \rightarrow \mathrm{M}_{2} \mathrm{CO}_{3}+\mathrm{N}_{2}+2 \mathrm{CO}_{2}+4 \mathrm{H}_{2} \\
2 \mathrm{C}_{3} \mathrm{H}_{8} \mathrm{O}+6 \mathrm{MNO}_{3} \rightarrow 3 \mathrm{M}_{2} \mathrm{CO}_{3}+3 \mathrm{~N}_{2}+3 \mathrm{CO}_{2}+4 \mathrm{H}_{2} \mathrm{O}+4 \mathrm{H}_{2} \\
5 \mathrm{C}_{3} \mathrm{H}_{8} \mathrm{O}+18 \mathrm{MNO}_{3} \rightarrow 9 \mathrm{M}_{2} \mathrm{CO}_{3}+9 \mathrm{~N}_{2}+6 \mathrm{CO}_{2}+20 \mathrm{H}_{2} \mathrm{O}\end{array}$ & $\begin{array}{l}\text { Several pathways are possible. Higher reductant efficiency } \\
\text { pathways utilize the reductant only to react with the } \mathrm{NO}_{3} \text {, and } \\
\text { utilize } \mathrm{CO}_{2} \text { from other sources (the fluidizing gas) to react with } \\
\mathrm{M}_{2} \mathrm{O} \text { intermediates to form } \mathrm{M}_{2} \mathrm{CO}_{3} \text {. Allowing the production of } \\
\text { various levels of } \mathrm{CO}, \mathrm{H}_{2} \text {, or solid carbon char will also affect } \\
\text { the reactant stoichiometry. More reductant is needed if } \mathrm{CO} \\
\text { rather than } \mathrm{CO}_{2} \text { is produced. } \mathrm{CO}_{2} \text { production is not favored in } \\
\text { high } \mathrm{CO}_{2} \text { atmospheres when } \mathrm{CO}_{2} \text { is used as the fluidizing gas. } \\
\text { More reductant is also required if the fluidizing } \mathrm{CO}_{2} \text { is reduced } \\
\text { to } \mathrm{CO} \text {, providing additional } \mathrm{O}_{2} \text { to react with the reductant. }\end{array}$ \\
\hline
\end{tabular}




\subsubsection{TWR/MTCI Reforming Technology}

The reforming technology offered by TWR for the treatment of SBW involves the use of a dense inert starting bed, such as alumina, which will become coated with product. The intent is to accumulate a layer of product that will subsequently attrit or spall off of the alumina to create either a seed particle for more product growth or fines that will elutriate from the bed. The alumina is attrition resistant and dense enough to have significant inertia. These are qualities that TWR believes should promote product disengagement from the alumina. TWR anticipated that the majority of the carbonate product would be collected in the cyclone and filter catches rather than permanently adhering to the alumina. To encourage the product to attrit, the nozzle atomizing ratio (NAR) and fluidizing velocities were kept as high as practical.

TWR uses carbon dioxide as the fluidizing, atomizing, and purge gases because it will not react with nitrogen to form $\mathrm{NO}_{\mathrm{x}}$; it does not include nitrogen that could interfere with the $\mathrm{NO}_{\mathrm{x}}$ decomposition; and it suppresses the formation and persistence of alkali hydroxides, which could agglomerate the bed.

Carbon monoxide and water react, in the water-gas shift reaction, to form hydrogen and carbon dioxide. This reaction [Equation (2-1)] promotes hydrogen production at the cost of carbon monoxide. Carbon monoxide, however, can also react with available hydrogen to form methane through a methanation reaction, shown in Equation (2-2). A high partial pressure of carbon dioxide may suppress the water-gas shift reaction and encourage methanation by keeping the carbon monoxide partial pressure somewhat higher. Carbon monoxide is the limiting reactant in either equation, so any process that increases the partial pressure of carbon monoxide will encourage the formation of methane. However, in spite of the high $\mathrm{CO}_{2}$ partial pressure, process temperatures favor the shift reaction over methanation.

$\mathrm{CO}+\mathrm{H}_{2} \mathrm{O} \leftrightarrow \mathrm{CO}_{2}+\mathrm{H}_{2} \quad$ water-gas shift reaction

$\mathrm{CO}+3 \mathrm{H}_{2} \leftrightarrow \mathrm{CH}_{4}+\mathrm{H}_{2} \mathrm{O} \quad$ methanation reaction

TWR asserts that methane (methyl radical) is the off-gas constituent that reacts most readily with $\mathrm{NO}_{\mathrm{x}}$ and is chiefly responsible for $\mathrm{NO}_{\mathrm{x}}$ destruction. To foster the production of methane and the destruction of nitrates and $\mathrm{NO}_{\mathrm{x}}$, TWR adds one or more carbonaceous reductants, one as a miscible liquid that is intimately mixed with the SBW and solid reductant than can be added to the bed as needed.

During the tests conducted in December 2002 (Marshall 2003a), the liquid reductant chosen was a $10 \mathrm{wt} \%$ solution of polyvinyl alcohol (PVOH) blended with the SBW on a 1:1 mass ratio. The solid reductant was polypropylene beads pneumatically injected into the bed. The combination of the two reductants achieved over $86 \%$ NOx destruction but resulted in organic and elemental carbon residues in the product between 4 and $6.5 \mathrm{wt} \%$ in the product fines.

For Phase 2, TWR substituted isopropyl alcohol (IPA) for the PVOH and was able to eliminate the use of polypropylene. As shown in Table 2-1, in the section on gaseous hydrocarbon chemistry, the decomposition and pyrolysis of IPA results in significant production of methane. The stoichiometry of nitrate reduction with IPA, as proposed by TWR, is given in Equation (2-3):

$2 \mathrm{C}_{3} \mathrm{H}_{8} \mathrm{O}+2 \mathrm{NaNO}_{3}+\mathrm{CO}_{2} \rightarrow \mathrm{Na}_{2} \mathrm{CO}_{3}+6 \mathrm{CO}+\mathrm{N}_{2}+\mathrm{H}_{2} \mathrm{O}+7 \mathrm{H}_{2}$

The TWR equation produces nearly equimolar proportions of carbon monoxide and hydrogen. Most of the carbon monoxide produced by this reaction mechanism would need to be converted via the water-gas shift reaction and methanation reactions to produce some of the hydrogen and methane that was detected in the off-gas. 
Another possible reaction mechanism is given by Equation (2-4), in which all products are fully oxidized and excess IPA is pyrolyzed for form additional methane.

$5 \mathrm{C}_{3} \mathrm{H}_{8} \mathrm{O}+18 \mathrm{NaNO}_{3} \rightarrow 9 \mathrm{Na}_{2} \mathrm{CO}_{3}+6 \mathrm{CO}_{2}+9 \mathrm{~N}_{2}+20 \mathrm{H}_{2} \mathrm{O}$

This equation does not indicate any carbon monoxide, methane, or hydrogen being produced. The excess IPA fed to the reactor (regardless of the actual reaction mechanism), may be reformed by the steam or pyrolyzed by the temperature to form other compounds, including carbon monoxide, methane, and hydrogen. Examples are given in Equations (2-5) through (2-7). Other radicals and recombination products are possible and the water-gas shift reaction would be responsible for depleting the carbon monoxide and generating more hydrogen as seen in Equation 2-1.

$\mathrm{C}_{3} \mathrm{H}_{8} \mathrm{O}+2 \mathrm{H}_{2} \mathrm{O} \rightarrow 3 \mathrm{CO}+6 \mathrm{H}_{2}$

$\mathrm{C}_{3} \mathrm{H}_{8} \mathrm{O} \rightarrow 2 \mathrm{CH}_{3}{ }^{\circ}+\mathrm{HCO}^{\bullet}+\mathrm{H}^{\cdot} \rightarrow 2 \mathrm{CH}_{4}+\mathrm{CO}$

and/or $\ldots \rightarrow \mathrm{C}_{2} \mathrm{H}_{6}+\mathrm{CO}+2 \mathrm{H}_{2}$

\subsubsection{Steam Reforming Product}

With the TWR technology, the liquid SBW nitrate waste can be converted into a dry alkali carbonate salt that is readily soluble. The solubility of the product makes recovery of a failed fluidized bed and remote decontamination more feasible and should be no more problematic than dissolving out calcine produced in the New Waste Calciner Facility. Under the assumption that the SBW will be reclassified as waste-incidental-to-reprocessing (WIR), the solubility of the product will not be detrimental for interment of the treated waste at the WIPP, unless the waste acceptance criteria are modified to require immobilization of RCRA hazardous constituents.

The more concentrated RCRA hazardous constituents in the SBW, except for cadmium, were included in the simulant so that the fate of the RCRA metals could be determined and documented. Similarly, non-radioactive cesium and rhenium (technetium surrogate) were added to enable a determination of the fate of these constituents as well. 


\section{MEASUREMENTS, SAMPLE COLLECTION, AND SAMPLE ANALYSIS}

Diagnostic activities performed during steam reformer tests included (a) continuous process measurements, including key process flow rates, temperatures, and pressures, (b) continuous off-gas composition measurements, and (c) sample collection for laboratory analysis. These diagnostic activities provided data for controlling the process operation and for determining the fate of feed constituents, product characteristics, and the off-gas composition.

\subsection{Process Measurements}

Process monitoring, process control, and data collection were performed primarily by the process logic controller (PLC). The PLC continuously and automatically monitored and controlled key system components and electronically logged key data. Process data not electronically logged by this system were recorded manually on operator data sheets. Control of process parameters not automatically controlled was also done according to operator discretion, the test plan, and steam reformer system operating instructions (SAIC 2003).

\subsection{Continuous Off-gas Composition Monitoring}

Continuous monitoring provided off-gas composition measurements for process control, air emissions measurements, and determination of the fate of feed constituents that are converted to gaseous compounds. Measurements were made at the outlet of the heated filter (inlet to the thermal oxidizer) and at operator-selected locations at the inlet of the carbon bed, or after each stage of the carbon bed. Four separate continuous emissions monitoring systems (CEMSs) were used. Analyzers used in each CEMS are summarized in Table 3-1.

CEMS 1 measures the steam reformer off-gas composition at the outlet of the heated filter, upstream of the thermal oxidizer, before the off-gas is oxidized. The CEMS 1 measurements are necessary for characterizing and controlling the steam reformer process.

Two Hg CEMSs were used to continuously monitor $\mathrm{Hg}$ concentrations upstream and downstream of the wet scrubber and the carbon bed.

CEMS 2 measures the off-gas composition downstream of the thermal oxidizer and wet scrubber. Like the second Hg CEMS, CEMS 2 sampling is selectable between inlet, intermediate stages, or outlet of the carbon bed.

\subsubsection{CEMS 1}

The off-gas composition at different locations in the off-gas system varies significantly, so the configurations of CEMSs 1 and 2 vary somewhat. The CEMS 1 for the filter outlet (thermal oxidizer inlet) measurements is shown in Figure 3-1. A heated sample probe is used to continuously extract a portion of the off-gas from the off-gas pipe. A heated filter at the back end of the heated probe removes particulate matter from the sample gas. The sample gas flows under negative pressure from the probe through a heated stainless steel sample line to the chiller system. Stainless steel is used for this sample line instead of more commonly used Teflon to better ensure retention of any $\mathrm{H}_{2}$ in the sample gas. 
Table 3-1. Analyzers used in the CEM systems.

\begin{tabular}{|c|c|c|c|c|c|c|c|c|}
\hline \multirow[b]{2}{*}{ Gas species } & \multirow[b]{2}{*}{ Instrument } & \multirow{2}{*}{$\begin{array}{c}\text { Detection } \\
\text { Principle }\end{array}$} & \multirow{2}{*}{$\begin{array}{c}\text { Instrument } \\
\text { Range }\end{array}$} & \multicolumn{4}{|c|}{ Acceptance Limits, \% FS } & \multirow{2}{*}{$\begin{array}{c}\text { Reference } \\
\text { Method }\end{array}$} \\
\hline & & & & Calibration & Drift & Linearity & Bias & \\
\hline \multirow[t]{2}{*}{$\mathrm{O}_{2}$} & Servomex 1440 (CEMS 1) & Paramagnetism & \multirow[t]{2}{*}{0 to $25 \%$} & \multirow[t]{4}{*}{2} & \multirow[t]{4}{*}{3} & \multirow[t]{4}{*}{4} & \multirow[t]{4}{*}{5} & \multirow{4}{*}{$\begin{array}{l}40 \text { CFR } \\
60 \text { App. } \\
\text { A Method } \\
3 \mathrm{~A}\end{array}$} \\
\hline & $\begin{array}{l}\text { Ametek WDG-IV in situ } \\
\mathrm{ZrO}_{2} \text { probe (CEMS 2) }\end{array}$ & $\begin{array}{l}\text { Electro- } \\
\text { chemical }\end{array}$ & & & & & & \\
\hline \multirow[t]{2}{*}{$\mathrm{CO}_{2}$} & Nova 4230 RM (CEMS 1) & \multirow[t]{2}{*}{$\begin{array}{l}\text { Nondispersive } \\
\text { infrared (NDIR) }\end{array}$} & $\begin{array}{l}0 \text { to } 40 \% \\
0 \text { to } 100 \% \\
\end{array}$ & & & & & \\
\hline & CAI ZRH (CEMS 2) & & $0-100 \%$ & & & & & \\
\hline $\mathrm{H}_{2}$ & Nova 4230 RM (CEMS 1) & $\begin{array}{l}\text { Thermal } \\
\text { conductivity }\end{array}$ & 0 to $5 \%$ & --- & --- & --- & --- & --- \\
\hline \multirow[t]{2}{*}{$\mathrm{CO}$} & CAI 200 (CEMS 1) & \multirow[t]{3}{*}{ NDIR } & $\begin{array}{l}0 \text { to } 1 \% \\
0 \text { to } 2 \% \\
\end{array}$ & \multirow[t]{2}{*}{5} & \multirow[t]{2}{*}{10} & \multirow[t]{2}{*}{2} & \multirow[t]{2}{*}{---} & \multirow{2}{*}{$\begin{array}{l}40 \text { CFR } \\
60 \text { App. } \\
\text { A Method } \\
10\end{array}$} \\
\hline & CAI ZRH (CEMS 2) & & $\begin{array}{l}0-500 \mathrm{ppm} \\
0-2,500 \mathrm{ppm}\end{array}$ & & & & & \\
\hline $\mathrm{CH}_{4}$ & CAI 200 (CEMS 1) & & $\begin{array}{l}0 \text { to } 0.5 \% \\
0 \text { to } 1 \% \\
\end{array}$ & --- & --- & --- & --- & --- \\
\hline \multirow[t]{2}{*}{$\mathrm{NO}, \mathrm{NO}_{\mathrm{x}}$} & Ametek M922 (CEMS 1) & $\begin{array}{l}\text { Dispersive } \\
\text { ultraviolet } \\
\text { (DUV) }\end{array}$ & $\begin{array}{l}0-5,000 \mathrm{ppm} \\
\mathrm{NO} \\
0-25,000 \\
\text { ppm } \mathrm{NO}_{2} \\
0-13,500 \\
\mathrm{ppm} \mathrm{SO}_{2}\end{array}$ & \multirow[t]{2}{*}{2} & \multirow[t]{2}{*}{3} & \multirow[t]{2}{*}{4} & \multirow[t]{2}{*}{5} & \multirow[t]{2}{*}{$\begin{array}{l}40 \text { CFR } \\
60 \text { App. } \\
\text { A Method } \\
7 \mathrm{E}\end{array}$} \\
\hline & $\begin{array}{l}\text { Thermo Environmental } \\
\text { Company (TECO) 42C } \\
\text { High Range (CEMS 2) }\end{array}$ & $\begin{array}{l}\text { Chemilumin- } \\
\text { escence }\end{array}$ & $0-4,000 \mathrm{ppm}$ & & & & & \\
\hline $\mathrm{THC}$ & $\begin{array}{l}\text { CAI } 300 \text { HFID (CEMS } 1 \\
\text { and 2) }\end{array}$ & $\begin{array}{l}\text { Flame ionization } \\
\text { detection (FID) }\end{array}$ & $0-3 \% \mathrm{C}$ & 5 & 3 & --- & --- & $\begin{array}{l}40 \text { CFR } \\
60 \text { App. } \\
\text { A Method } \\
25 \mathrm{~A}\end{array}$ \\
\hline $\mathrm{SO}_{2}$ & Ametek M921 (CEM 2) & $\begin{array}{l}\text { Dispersive } \\
\text { ultraviolet } \\
\text { (DUV) }\end{array}$ & $0-500 \mathrm{ppm}$ & 2 & 3 & 4 & 5 & $\begin{array}{l}40 \text { CFR } \\
60 \text { App. } \\
\text { A Method } \\
6 \mathrm{C}\end{array}$ \\
\hline $\mathrm{HCl}$ & TECO 15C (CEMS 2) & $\begin{array}{l}\text { NDIR with gas } \\
\text { filter correlation } \\
(\mathrm{GFC})\end{array}$ & $\begin{array}{l}0-5 \mathrm{ppm} \text { to } \\
0-5,000 \mathrm{ppm}\end{array}$ & --- & --- & --- & --- & --- \\
\hline $\begin{array}{l}\text { Total and } \\
\text { elemental } \\
\mathrm{Hg}\end{array}$ & $\begin{array}{l}\text { PSA Analytical Sir } \\
\text { Galahad (CEMS } 3 \text { and 4) }\end{array}$ & $\begin{array}{l}\text { Atomic } \\
\text { fluorescence }\end{array}$ & $\begin{array}{l}0-3,000 \\
\mathrm{ug} / \mathrm{m}^{3}\end{array}$ & --- & --- & --- & --- & --- \\
\hline
\end{tabular}




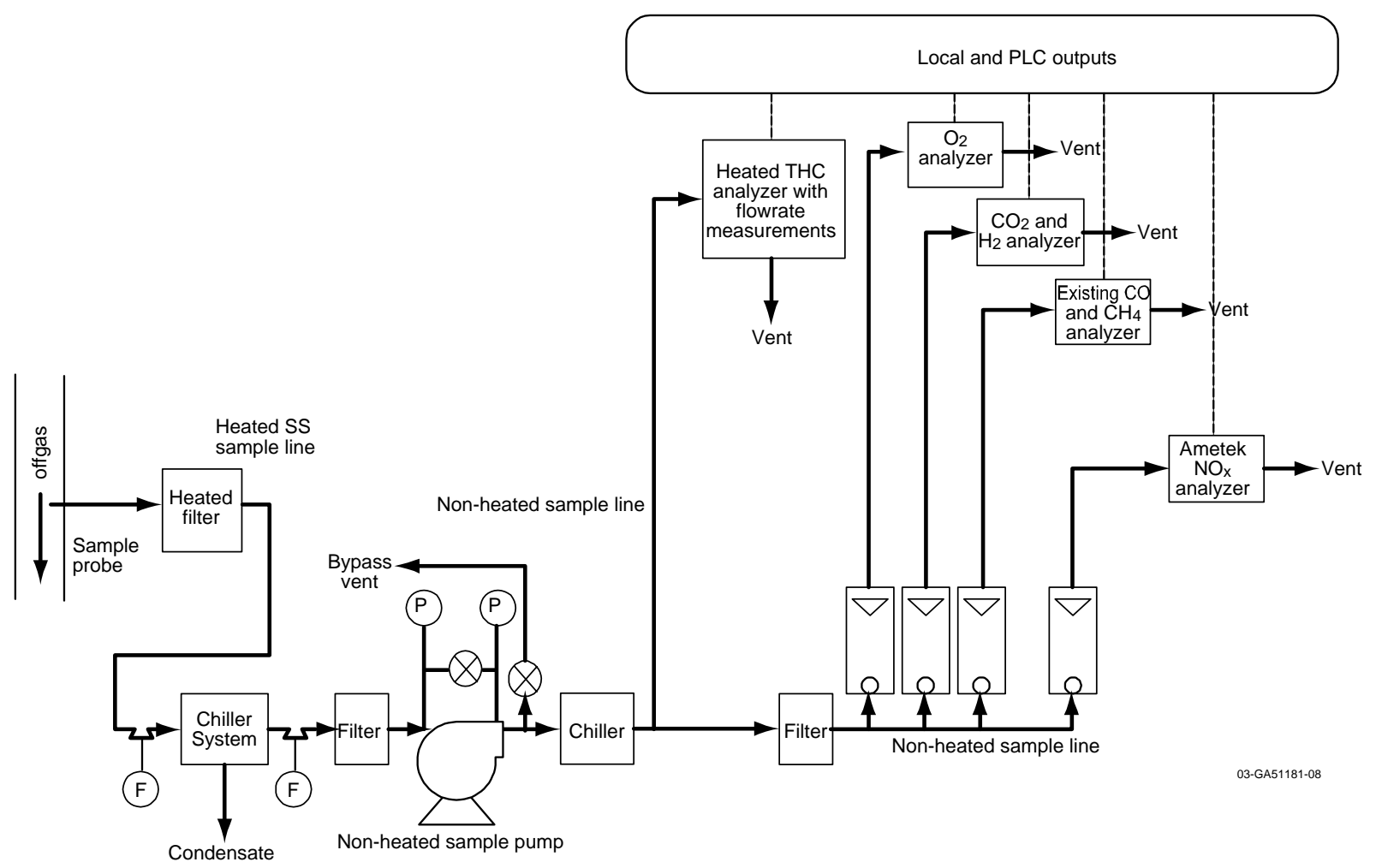

Figure 3-1. CEMS 1 for steam reformer off-gas measurements at the filter outlet sample location, upstream of the thermal oxidizer.

The wet sample gas flow rate is measured upstream of the chiller using a Micromotion coriolis meter. This meter measures the mass flow rate independent of gas composition or density. The gas flow rate is measured here and also downstream of the chiller, after moisture is removed, to determine the moisture content of the sample gas.

The chiller system cools the sample gas and removes moisture. In this design, some of the watersoluble gases like $\mathrm{NO}_{2}$ and $\mathrm{HCl}$, and some higher molecular weight or water-soluble hydrocarbons, if present, could be captured with the water condensate. If so, those amounts of condensed or scrubbed gases would not be detected by the analyzers. More complex ways to better retain these gases in the sample gas are available, but have not been implemented in this test system due to their cost and complexity.

Two actions were taken to minimize and quantify lost soluble/condensable gas species. First, the chiller system was designed according to guidance in EPA 2002 to minimize acid gas scrubbing. Second, condensate samples were collected for analysis as a quality-assurance check to determine amounts, if any, of condensed or scrubbed species. Results of these analyses from prior tests have shown negligible $\mathrm{NO}_{\mathrm{x}}$ scrubbing (Marshall 2003a, Marshall 2003b, Soelberg 2003a). The sample gas is analyzed on a dry basis because the chiller removes moisture from the sample gas.

All components downstream of the sample gas chiller system are unheated because most of the condensable moisture is removed in the chiller. The sample pump induces the negative pressure needed to draw the sample gas from the off-gas pipe into the CEMS. A small backup chiller and a backup filter 
located immediately downstream of the sample pump provide added protection for the flow meters and analyzers from condensate or particulate matter damage or fouling.

The components of the sample pump, and all other components of the CEMS that contact the sample gas, are constructed of stainless steel, Teflon, glass, or other materials designed to avoid reaction with the sample gas.

The chilled and conditioned off-gas was split and delivered through valved rotameters to the various analyzers.

The dispersive ultraviolet (DUV) Ametek analyzer detects $\mathrm{NO}$ and $\mathrm{NO}_{2}$ simultaneously. This analyzer can also detect $\mathrm{SO}_{2}$ by DUV. This analyzer replaced the Ecophysics chemiluminescent $\mathrm{NO}_{\mathrm{x}}$ analyzer used in prior tests because (a) the chemiluminescent analyzer used at this sample location was subject to interferences and required air dilution of the sample gas to mitigate some of this interference, and (b) the chemiluminescent analyzer was relocated to sample the fully oxidized off-gas downstream of the thermal oxidizer, where interferences to the chemiluminescent analysis are mitigated.

While the DUV analyzer was expected to be relatively impervious to interferences, considerable interferences on this analyzer were observed during the two weeks of the test. Ametek theorizes that the interferences are due to levels of hydrocarbons that are higher in the steam reformer off-gas than are found in most other off-gases. The interferences caused a bias on the measured NO values. The interferences were significant enough on the $\mathrm{NO}_{2}$ readings that these readings from this analyzer were not valid during the two-week test. The NO readings were corrected for the measurement bias. The corrected NO readings are useable estimates of the NO levels in the off-gas.

\subsubsection{Partial Quench Outlet and Carbon Bed Inlet Hg CEM}

Continuous mercury measurements were made at the thermal oxidizer outlet (inlet to the partial quench) and at the inlet of the carbon bed using a PSA Analytical Sir Galahad continuous mercury analyzer system, shown in Figure 3-2. This single analyzer is equipped with 2 separate sampling and conditioning systems, one each dedicated to the two separate sampling locations. Using 2 separate sampling and conditioning systems minimizes potential interferences from sampling artifacts at one location on the measurements for the other location.

Hg Continuous Sampling Train (CST) 3 was used to extract and condition relatively high-Hg offgas from sample locations downstream of the thermal oxidizer (upstream of the partial quench and wet scrubber) and downstream of the reheater (upstream of the carbon bed). Hg CST 4 was used to extract and condition relatively low-Hg off-gas from any of the two selectable locations in between each of the three stages of carbon in the carbon bed or at the carbon bed outlet. The diluted, conditioned off-gas from CST 3 and 4 are delivered to the single $\mathrm{Hg}$ CEM. The Hg CEM sequentially measures elemental and total $\mathrm{Hg}$ for each of the two CSTs. The cycle time for the Hg CEM to make all four measurements required 20-30 minutes, depending on the sampling time for each of the four input sample gas streams.

The high-Hg off-gas was diluted in CST-3 by up to 120:1 to lower the expected Hg levels to ranges within the instrument full-scale range of $0-3,000 \mathrm{ug} / \mathrm{dscm}$. The lower-Hg off-gas downstream of the carbon bed was diluted by up to $80: 1$.

For each sampling and conditioning system, the sample gas was extracted from the sample location through a heated probe, and filtered using a heated filter. This filter was designed for occasional pulsing to remove any particulate matter (PM), blowing it back into the off-gas system. 


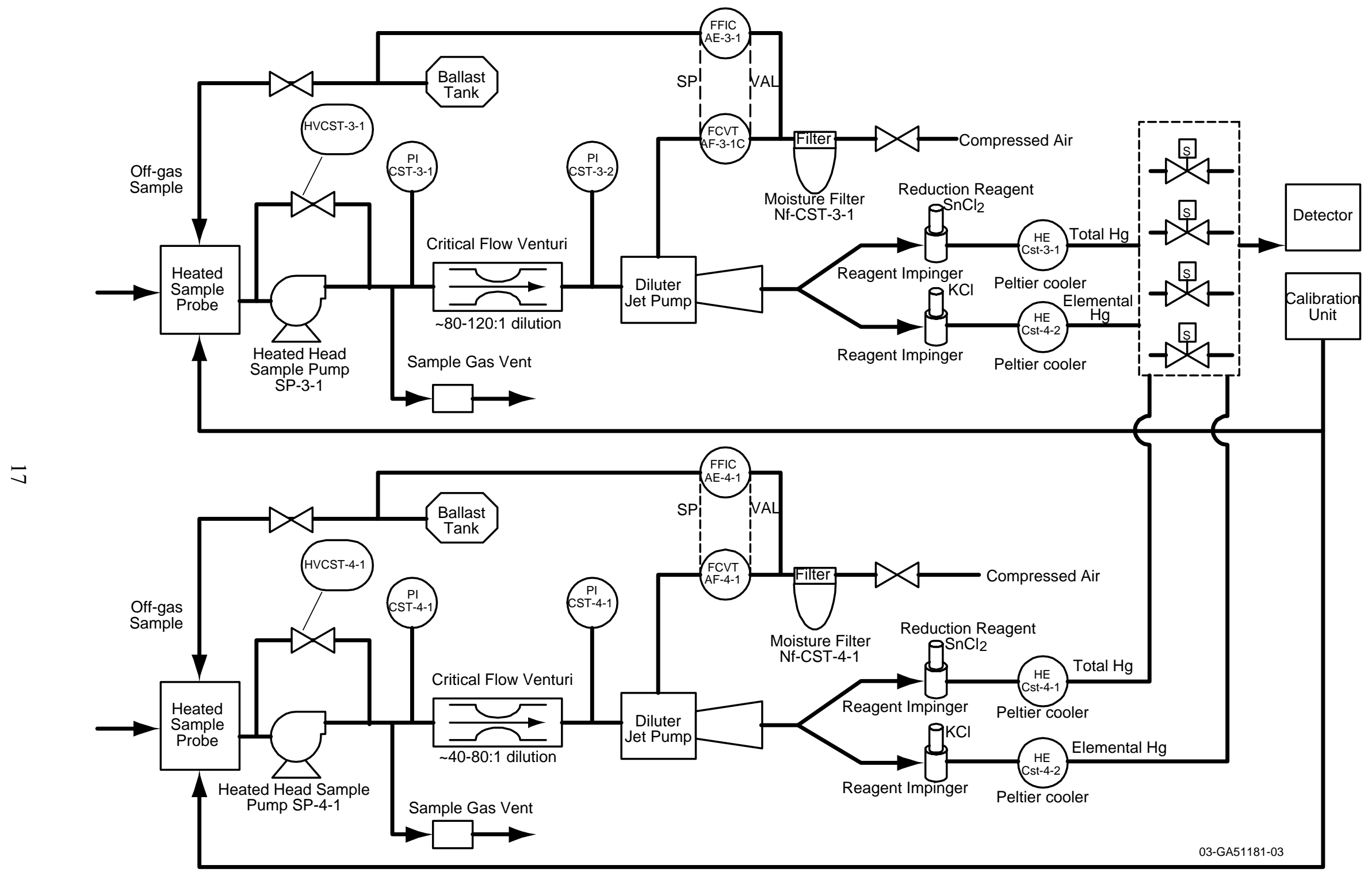

Figure 3-2. PSA analytical Hg CEMS, with dual sampling and conditioning systems. 
A heated head sample pump was used to provide positive pressure to the critical flow venturi to ensure that the flow of sample gas through the venturi is choked flow. Choked flow, necessary for proper operation of the critical flow venturi, occurs when the static pressure upstream of the venturi is at least twice the static pressure downstream of the venturi. The venturi upstream pressure and the flow rate of dilution gas (compressed air or nitrogen) to the diluter jet pump establish the dilution factor. The upstream pressure is controlled using a control valve on the sample pump bypass. The flow rate of sample gas through the filter and sample pump is controlled using a bypass valve and rotameter to ensure that, even when the sample gas is diluted, sufficient sample gas flows through the sampling system to minimize $\mathrm{Hg}$ measurement bias due to low sample flow rate.

The diluted sample gas flows through either of two selectable pathways that enable separate measurement of either total $\mathrm{Hg}$ or only elemental $\mathrm{Hg}$. In the total $\mathrm{Hg}$ measurement mode, the sample gas flows through an impinger system containing stannous chloride solution, which converts any oxidized $\mathrm{Hg}$ (principally $\mathrm{HgCl}_{2}$ ) to $\mathrm{Hg}^{0}$. The sample then flows through a Peltier cooler to the $\mathrm{Hg}$ analyzer, where total $\mathrm{Hg}$ is measured. In the elemental $\mathrm{Hg}$ measurement mode, the sample gas flows through an impinger system containing $\mathrm{KCl}$ solution, which scrubs any oxidized $\mathrm{Hg}$ species out of the sample gas but allows elemental $\mathrm{Hg}$ to pass through. The sample gas flows from this impinger system through a separate Peltier cooler to the $\mathrm{Hg}$ analyzer, where only elemental $\mathrm{Hg}$ is measured.

\subsubsection{CEMS 2}

CEMS 2 was used to monitor the fully oxidized off-gas downstream of the thermal oxidizer. The thermal oxidizer outlet $\mathrm{O}_{2}$ measurement was fixed at that location, but the sample probe for the other CEMS 2 analyzers was switchable between the inlet of the carbon bed and the outlet of the carbon bed, or between any intermediate carbon bed stage.

The CEMS 2 is shown in Figure 3-3. While some of the analyzers for CEMS 2 were different from CEMS 1, the sampling and conditioning system was identical to that of CEMS 1, except that coriolis meters were not used to measure the CEMS 2 off-gas moisture content.

Since off-gas measured by CEMS 2 was similar to typical combustion off-gas, the analyzers were typical of those that work well on combustion off-gases with minimal interferences. Analyzers used in CEMS 2 are listed in Table 3-1.

\subsection{Process Sample Collection and Analysis}

Process samples were collected and analyzed to characterize feed and product streams, perform key mass balances, and determine the fate of feed constituents in the steam reforming process. Over 200 samples were collected during the TWR tests. Process streams sampled include the feed stimulant; carbon additives; bed, cyclone, and filter solids; scrub solution; off-gas; and CEMS condensates. Depending on sample matrix and analysis objectives, the samples were analyzed for a wide variety of analyses. Hundreds of analyses were performed to identify and quantify dozens of analytes and characteristics of the samples. 


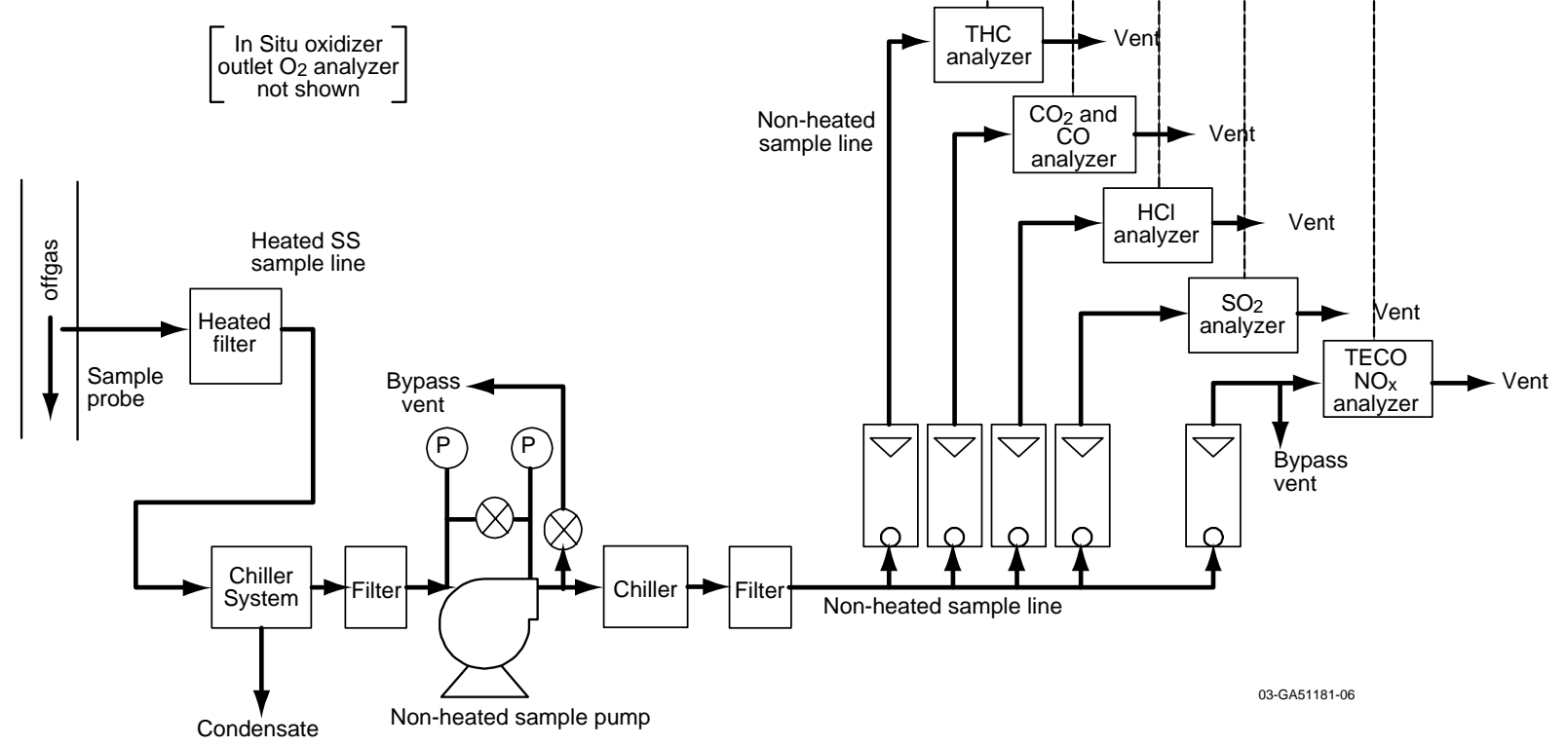

Figure 3-3. CEMS 2 for steam reformer off-gas measurements downstream of the carbon bed.

Sample analysis procedures are summarized in Table 3-2. Depending on the analysis complexity, analysis procedures, and turnaround time goals, some analyses were performed on site at the SAIC STAR Center, the INEEL Research Center (IRC), the INEEL Analytical Laboratory Department (ALD), and the laboratory at the INEEL Test Reactor Area (TRA). Some analyses that were relatively simple and used simple or mobile equipment were performed at the STAR Center in order to speed turnaround time. Speedy results of some analyses such as particle size, nitrate content, carbonate content, and carbon content were used to facilitate the parametric tests and to diagnose the health of the reformer system. Performing these analyses onsite at the STAR Center enabled turnaround times of a few hours or less for some analyses. More complex analyses or those that required larger or more expensive equipment than can be readily transported to the STAR Center were performed in laboratories at the INEEL.

Many of the analyses at the STAR Center and other laboratories were simplified or optimized from more complex or traditional analytical procedures. 
Table 3-2. Sample analysis procedures.

\begin{tabular}{|c|c|c|c|c|c|}
\hline Analytes & Method (reference) & Analysis technique & $\begin{array}{c}\text { Detection } \\
\text { limits }\end{array}$ & Performed at: & Method summary, comments \\
\hline Total mass & $\begin{array}{l}\text { Good laboratory } \\
\text { practice }\end{array}$ & Calibrated laboratory balance & $\begin{array}{l}\text { Depends } \\
\text { on range }\end{array}$ & $\begin{array}{l}\text { All laboratories } \\
\text { used in the test } \\
\text { program }\end{array}$ & $\begin{array}{l}\text { Using an appropriately ranged, calibrated balance, determine the net weight of } \\
\text { sample by subtracting the container tare weight from the total weight of the } \\
\text { sample and the container. }\end{array}$ \\
\hline Nitrate & \multicolumn{2}{|c|}{ Onsite at the STAR Center: Sulphonated phenol colorimetry } & $\sim 0.1 \mathrm{wt} \%$ & $\begin{array}{l}\text { STAR Center, } \\
\text { TRA }\end{array}$ & $\begin{array}{l}\text { Treat solid product or dried water leachate with sulphonated phenol/ } \mathrm{H}_{2} \mathrm{SO}_{4}-\text { add } \\
\text { excess base and measure absorbance @ } 400 \mathrm{~nm}\end{array}$ \\
\hline Carbonate & \multicolumn{2}{|c|}{$\begin{array}{l}\text { Volumetric determination of } \mathrm{CO}_{2} \text { evolved from solid-phase } \\
\mathrm{CO}_{3}\end{array}$} & $\sim 0.5 \mathrm{wt} \%$ & $\begin{array}{l}\text { STAR Center, } \\
\text { TRA }\end{array}$ & $\begin{array}{l}\text { React sample with hot } \mathrm{H}_{2} \mathrm{SO}_{4} \text { in a syringe, normalize its pressure, and measure the } \\
\text { volume of } \mathrm{CO}_{2} \text { released }\end{array}$ \\
\hline Bulk density & \multicolumn{2}{|c|}{ Gravimetric and volumetric analysis } & $\sim 0.1 \mathrm{~g} / \mathrm{mL}$ & $\begin{array}{l}\text { STAR Center, } \\
\text { TRA, IRC }\end{array}$ & $\begin{array}{l}\text { Fill a tared graduate cylinder, tap for } \sim 30 \text { seconds to settle, measure the mass and } \\
\text { volume }\end{array}$ \\
\hline $\begin{array}{l}\text { Particle ("true") } \\
\text { density }\end{array}$ & \multicolumn{2}{|c|}{ Gravimetric and volumetric analysis } & --- & $\begin{array}{l}\text { STAR Center, } \\
\text { TRA }\end{array}$ & $\begin{array}{l}\text { Determine bulk density, then fill in interstitial space with hexane or other liquid } \\
\text { that does not dissolve solid particles, reweigh to determine the void volume, } \\
\text { subtract the void volume from the bulk volume, and determine void-free density. }\end{array}$ \\
\hline $\begin{array}{l}\text { Total Organic } \\
\text { Carbon (TOC, } \\
\text { Loss on Ignition) }\end{array}$ & & Gravimetry & $0.1 \mathrm{wt} \%$ & TRA & $\begin{array}{l}\text { Dry solid sample in convection oven at } 105^{\circ} \mathrm{C} \text {. Heat a known mass of the dried } \\
\text { solid in a ceramic crucible at } 500^{\circ} \mathrm{C} \text { for } 10 \text { minutes to burn off carbon. Cool \& } \\
\text { reweigh. Does not discriminate between carbonate and organic carbon. }\end{array}$ \\
\hline TOC & $\begin{array}{l}\text { Chemical oxygen } \\
\text { demand (COD) } \\
\text { determination }\end{array}$ & Colorimetry & $0.01 \mathrm{wt} \%$ & $\begin{array}{l}\text { STAR Center \& } \\
\text { TRA }\end{array}$ & $\begin{array}{l}\text { React sample with chromate in hot concentrated sulfuric acid. Determine } \\
\text { chromate consumption colorimetrically and calculate TOC content. Applicable to } \\
\text { low-level TOC solid and liquid samples. }\end{array}$ \\
\hline $\begin{array}{l}\text { Total inorganic } \\
\text { carbon (TIC) and } \\
\text { TOC for liquid } \\
\text { samples }\end{array}$ & \multicolumn{2}{|c|}{$\begin{array}{l}\text { Persulfate-Ultraviolet Oxidation/Combustion-Infrared method } \\
5310 \mathrm{~B} / \mathrm{C} \text { (PUO-IM) }\end{array}$} & $\sim 0.1 \mathrm{wt} \%$ & IRC & Gasifies organic and inorganic carbon from liquid samples. \\
\hline Elemental & $\begin{array}{l}\text { SW-846 } 6000 \text { or } 7000 \\
\text { series or equivalent }\end{array}$ & $\begin{array}{l}\text { Inductively-coupled plasma atomic } \\
\text { emission spectroscopy (ICP-AES) } \\
\text { for most metals; ICP-mass } \\
\text { spectroscopy (ICP-MS) for Cs and } \\
\text { Re; cold vapor atomic absorption } \\
\text { (CVAA) spectroscopy for Hg }\end{array}$ & $1 \mathrm{mg} / \mathrm{L}$ & $\begin{array}{l}\text { IRC, and ALD, } \\
\text { (ICP-AES; TRA } \\
\text { (ICP-MS); ALD } \\
\text { (CVAA) }\end{array}$ & $\begin{array}{l}\text { Completely digest per EPA } 3050 \text { or equivalent for all elements. If } \mathrm{HF} \text { is needed } \\
\text { for complete dissolution, then perform a second lithium borate fusion and } \\
\text { digestion in } \mathrm{HNO}_{3} \text { for } \mathrm{Si} \text { analysis. ICP analysis of digested solution (CVAA } \\
\text { analysis for } \mathrm{Hg} \text { ). If no solids are present in liquid samples, digestion will not be } \\
\text { done. }\end{array}$ \\
\hline $\begin{array}{l}\text { Anions (not } \\
\text { including } \mathrm{CO}_{3} \text { ) }\end{array}$ & $\begin{array}{l}\text { SW-846 } 9056 \text { or } \\
\text { equivalent }\end{array}$ & Ion chromatography (IC) & $1 \mathrm{mg} / \mathrm{L}$ & IRC & $\begin{array}{l}\text { Water digestion (of solids) followed by analysis per } 9056 \text {. If no solids are present } \\
\text { in liquid samples, digestion was not done. }\end{array}$ \\
\hline Moisture & $\begin{array}{l}\text { ASTM D } 3273 \text { or } \\
\text { equivalent (b) }\end{array}$ & Gravimetry & $1 \mathrm{mg}$ & $\begin{array}{l}\text { STAR Center, } \\
\text { TRA }\end{array}$ & $\begin{array}{l}\text { Weigh sample, dry in oven at a temperature between } 104-110^{\circ} \mathrm{C} \text {, reweigh to } \\
\text { constant weight, calculate } \% \text { moisture. }\end{array}$ \\
\hline $\mathrm{Hg}$ & $\begin{array}{l}\text { SW846 } 7470 \text { or } \\
\text { equivalent }\end{array}$ & CVAA & $1 \mathrm{mg} / \mathrm{kg}$ & ALD & $\begin{array}{l}\text { Digest sample per SW-846 } 3050 \text { and analyze by CVAA; re-digest solid residues } \\
\text { to determine completeness of the first digestion }\end{array}$ \\
\hline $\begin{array}{l}\text { Anions } \mathrm{Cl}, \mathrm{F}, \mathrm{I} \text {, } \\
\text { nitrate }\end{array}$ & SW-846 & IC & $1 \mathrm{mg} / \mathrm{L}$ & IRC & Water dissolution followed by analysis per 9056 \\
\hline $\mathrm{S}$ & SW-846 6000 & IC & & ALD & $\begin{array}{l}\text { Total digestion (of non-carbon solids) per EPA } 3050 \text { followed by analysis per } \\
9056 .\end{array}$ \\
\hline
\end{tabular}


Table 3-2. Sample analysis procedures (continued).

\begin{tabular}{|c|c|c|c|c|c|}
\hline Analytes & Method (reference) & Analysis technique & $\begin{array}{c}\text { Detection } \\
\text { limits }\end{array}$ & Performed at: & Method summary, comments \\
\hline Volatile Matter & $\begin{array}{l}\text { ASTM D } 3175 \text { or } \\
\text { equivalent (b) }\end{array}$ & Gravimetric & & & $\begin{array}{l}\text { Volatilize VOCs at a controlled temperature and time; determine weight loss, } \\
\text { differentiating between weight loss from VOCs and weight loss from other } \\
\text { volatile constituents such as water and carbonate. }\end{array}$ \\
\hline $\begin{array}{l}\text { Optical } \\
\text { microscopy }\end{array}$ & \multicolumn{2}{|c|}{$\begin{array}{l}\text { Use optical microscope to observe particle properties. Use } \\
\text { camera to document particle properties. }\end{array}$} & $\begin{array}{l}\sim 10-100 \\
\text { um }\end{array}$ & IRC & $\begin{array}{l}\text { Document visible particle properties - shape, appearance, etc. Count numbers of } \\
\text { particles within selected size ranges in the field of view or in grids in the field of } \\
\text { view }\end{array}$ \\
\hline Water solubility & $\begin{array}{l}\text { Good laboratory } \\
\text { practice }\end{array}$ & Commercial conductivity meter & $\sim 0.1 \mathrm{wt} \%$ & $\begin{array}{l}\text { STAR Center, } \\
\text { TRA }\end{array}$ & $\begin{array}{l}\text { Add measured amounts of solid to a known volume of boiling, stirred water until } \\
\text { the water clouds with undissolved matter. Measure electrical conductivity of the } \\
\text { water and compare to conductivity curves. }\end{array}$ \\
\hline $\begin{array}{l}\text { Submicron particle } \\
\text { morphology }\end{array}$ & \multicolumn{2}{|c|}{ Scanning electron microscope (SEM) } & --- & $\begin{array}{l}\text { Mount on stages, } \\
\text { sputter with } \\
\text { conducting } \\
\text { carbon or gold }\end{array}$ & $\begin{array}{l}\text { Determine and document submicron particle structures, including surface deposits } \\
\text { or layers, and individual submicron particles }\end{array}$ \\
\hline \multirow[t]{3}{*}{ Particle size } & $\begin{array}{l}\text { ASTM D 293, adapted } \\
\text { to granule particle size } \\
\text { detrmination }\end{array}$ & Sieve trays & $<1 \mathrm{um}$ & & $\begin{array}{l}\text { Mechanically separate particles of different sizes on calibrated sieve trays; } \\
\text { determine the net weight of each size cut by subtracting the sieve tare weight } \\
\text { from the total weight of the sample and the sieve. }\end{array}$ \\
\hline & --- & Coulter counter & $<1 \mathrm{um}$ & & \\
\hline & --- & Particle counting & $\sim 0.1 \mathrm{um}$ & & $\begin{array}{l}\text { Use particle counting/sizing software or visual observation to count and estimate } \\
\text { sizes of particles in micrographs. }\end{array}$ \\
\hline $\mathrm{pH}$ & \multicolumn{2}{|l|}{ Commercial $\mathrm{pH}$ probe } & & --- & \\
\hline
\end{tabular}




\section{SBW SIMULANT COMPOSITIONS}

SBW at INTEC varies somewhat in composition from tank to tank and in the quantity of undissolved solids that have accumulated on the bottom of the tanks. For the purposes of this test and the ability to compare the results of this test with outcomes using other technologies, the simulated SBW formulation was designed to represent the waste stored in waste tank WM-180, which has better characterization data than most of the waste tanks.

Non-radioactive simulants designed to simulate the SBW in Tank WM180 were prepared by SAIC to produce the compositions shown in Table 4-1. The actual compositions determined by laboratory analysis of feed samples are also shown. Mass balance calculations were generally made using the compositions calculated from the feed recipes, rather than using the laboratory analyses. Most of the time, the calculated compositions from the feed recipes would be more accurate than the laboratory analyses, as long as there were no mistakes in the feed preparation, and as long as the reagents used in the recipes were relatively pure. Laboratory analyses can often be subject to errors if the samples do not exactly represent the stimulant. Laboratory analyses are often subject to errors up to $10-20 \%$ of the measured values.

The laboratory analyses are compared to the compositions based on the feed compositions to identify if there are any significant anomalies due to preparation errors or reagent impurities that would affect mass balance closure calculations.

Heel solids were simulated by precipitation of various aluminate, silicate, phosphate, and fluoride salts. The chemical structure of the salts is not known. Most of the precipitates are so finely divided that crystalline diffraction patterns could not be elucidated. The composition of the three solutions used to form the precipitate is given in Table 4-2. Difficulty in filtering the fine precipitate precluded it from being washed of interstitial liquids containing dissolved solids. After drying the slurry, attempts were made to grind the clumps, clusters, and crystals (if any) so that the solids could be reliably fed to the process without causing undue feed line restrictions. Problems were encountered with blockages in the feed-line check valves and in the feed nozzle, which lead to processing an SBW simulant without heel solids during a portion of the campaign. Feed nozzle plugging was eventually ameliorated by filtering and settling out the larger solids from the simulant.

WM-180 is expected to contain about 0.23 grams of undissolved solids (UDS) per liter of solution (Barnes 2001). This is among the lowest concentrations of UDS among the SBW tanks. The tank with the highest estimated UDS content is WM-186, which contains about 5.05 grams UDS per liter of solution.

The heel solids metathesis recipe was expected to form sufficient precipitate to enable adding 5 grams of UDS for each liter of supernate simulant. Difficulties occurred during preparation that resulted in adding only $1.34 \mathrm{~kg}$ of solids to 800 liters of simulant. The UDS concentration based on the added solids was $1.68 \mathrm{gm} / \mathrm{L}$ less than the estimated value in Tank WM186, but more than in Tank WM-180. The solids preparation did not go as planned because the solids slurry could not be filtered and did not centrifuge well. The solid residue following centrifugation was dried without further washing. Some material precipitated from the centrifuged solution, suggesting that some aluminum nitrate was not precipitated with the silicates. Regardless of these difficulties in preparation, the dried solids were added to the simulant and were considered a suitable representation of the UDS in the SBW. 
Table 4-1. Simulant compositions for the TWR test series.

\begin{tabular}{|c|c|c|c|c|c|c|c|c|c|}
\hline \multirow{2}{*}{\multicolumn{2}{|c|}{$\begin{array}{l}\text { Test number } \\
\text { Simulant }\end{array}$}} & \multicolumn{4}{|c|}{5.3 and 5.4} & \multicolumn{4}{|c|}{0.1 through $5.3(\mathrm{f})$} \\
\hline & & \multicolumn{4}{|c|}{ New SBW w/o heel solids } & \multicolumn{4}{|c|}{ New SBW with residual heel solids $(a, b)$} \\
\hline \multirow[b]{3}{*}{ Component } & \multirow{3}{*}{$\begin{array}{c}\text { Mole } \\
\text { weight }\end{array}$} & \multicolumn{8}{|c|}{ Composition } \\
\hline & & \multicolumn{2}{|c|}{$\begin{array}{l}\text { Calculated from } \\
\text { simulant } \\
\text { supernate recipe }\end{array}$} & \multirow{2}{*}{$\begin{array}{c}\begin{array}{c}\text { Measured } \\
\text { (Sample 86) }\end{array} \\
\mathrm{gm} / \mathrm{L} \\
\end{array}$} & \multirow{2}{*}{$\begin{array}{l}\mathrm{RPD}, \% \\
\text { (c) }\end{array}$} & \multicolumn{2}{|c|}{$\begin{array}{l}\text { Calculated from } \\
\text { simulant and heel } \\
\text { solids recipe }\end{array}$} & \multirow{2}{*}{$\begin{array}{c}\text { Measured } \\
\text { (Sample 116) } \\
\mathrm{gm} / \mathrm{L}\end{array}$} & \multirow{2}{*}{$\begin{array}{l}\text { RPD, \% } \\
\text { (c) }\end{array}$} \\
\hline & & $M$ & $\mathrm{gm} / \mathrm{L}$ & & & $M$ & $\mathrm{gm} / \mathrm{L}$ & & \\
\hline Acid & 1.0 & 1.12 & 1.1 & $\mathrm{NM}$ & $\overline{---}$ & 1.1 & 1.1 & NA & --- \\
\hline Aluminum & 27.0 & 0.66 & 18 & 16.590 & $8 \%$ & 0.66 & 18 & 17.080 & $5 \%$ \\
\hline Boron & 10.8 & 0.012 & 0.13 & 0.094 & $34 \%$ & 0.012 & 0.13 & 0.098 & $30 \%$ \\
\hline Calcium & 40.1 & 0.047 & 1.9 & 1.752 & $8 \%$ & 0.048 & 1.9 & 1.802 & $6 \%$ \\
\hline Cesium & 132.9 & 0.0032 & 0.43 & 0.398 & $8 \%$ & 0.0032 & 0.43 & 0.245 & $54 \%$ \\
\hline Chromium & 52.0 & 0.0033 & 0.17 & 0.121 & $36 \%$ & 0.0033 & 0.17 & 0.160 & $8 \%$ \\
\hline Copper & 63.5 & 0.0007 & 0.044 & 0.037 & $19 \%$ & 0.0007 & 0.044 & 0.029 & $40 \%$ \\
\hline Iron & 55.9 & 0.022 & 1.2 & 0.607 & $67 \%$ & 0.022 & 1.2 & 1.150 & $6 \%$ \\
\hline Lead & 207.2 & 0.0013 & 0.27 & 0.234 & $16 \%$ & 0.0013 & 0.27 & 0.239 & $13 \%$ \\
\hline Magnesium & 24.3 & 0.012 & 0.29 & 0.326 & $11 \%$ & 0.012 & 0.30 & 0.327 & $9 \%$ \\
\hline Manganese & 54.9 & 0.014 & 0.77 & 0.758 & $2 \%$ & 0.014 & 0.78 & 0.752 & $4 \%$ \\
\hline Mercury & 200.6 & 0.0014 & 0.27 & 0.259 & $5 \%$ & 0.0013 & 0.27 & 0.267 & $1 \%$ \\
\hline Nickel & 58.7 & 0.0015 & 0.086 & 0.075 & $14 \%$ & 0.0015 & 0.086 & 0.080 & $7 \%$ \\
\hline Potassium & 39.1 & 0.20 & 7.7 & 7.441 & $3 \%$ & 0.19 & 7.6 & 7.861 & $3 \%$ \\
\hline Rhenium & 186.2 & 0.0011 & 0.20 & 0.188 & $6 \%$ & 0.0011 & 0.20 & 0.197 & $1 \%$ \\
\hline Silicon & 28.1 & --- & --- & 0.046 & --- & 0.0053 & 0.15 & 0.012 & $170 \%$ \\
\hline Sodium & 23.0 & 2.1 & 47 & 55.370 & $16 \%$ & 2.1 & 47 & 49.870 & $5 \%$ \\
\hline Tin & 118.7 & --- & --- & 0.001 & --- & 0.000 & 0.052 & 0.000 & $199 \%$ \\
\hline Zinc & 65.4 & 0.0011 & 0.069 & 0.070 & $2 \%$ & 0.001 & 0.068 & 0.073 & $7 \%$ \\
\hline Zirconium & 91.2 & --- & --- & 0.000 & --- & 0.000 & 0.034 & 0.000 & $195 \%$ \\
\hline Chloride & 35.5 & 0.030 & 1.1 & 1.184 & $11 \%$ & 0.031 & 1.1 & 1.236 & $13 \%$ \\
\hline Fluoride (e) & 19.0 & 0.024 & 0.45 & 0.489 & $8 \%$ & 0.047 & 0.45 & 0.476 & $6 \%$ \\
\hline Nitrate & 62.0 & 5.3 & 330 & 263.478 & $22 \%$ & 5.3 & 330 & 306.902 & $7 \%$ \\
\hline Phosphate & 95.0 & 0.029 & 2.7 & NM & --- & 0.031 & 2.9 & 0.000 & --- \\
\hline Sulfate & 96.1 & 0.070 & 6.7 & 7.540 & $12 \%$ & 0.070 & 6.7 & 7.928 & $16 \%$ \\
\hline Total & & & & & & & & & \\
\hline TDS+UDS & --- & 9.638 & 421 & & & 9.7 & 421 & & \\
\hline Water & 18.0 & -- & 838 & & & --- & 844 & & \\
\hline Heel solids & --- & --- & --- & & & --- & 2 & & \\
\hline Density (d) & --- & --- & 1,259 & 1,270 & 0.8 & --- & 1,267 & 1,240 & 2.2 \\
\hline
\end{tabular}

a. Simulant was prepared by adding simulated heel solids. Instead of the planned UDS level of $5 \mathrm{gm} / \mathrm{L}$, the actual starting UDS concentration was $1.68 \mathrm{mg} / \mathrm{L}$. The elemental concentration shown above is based on the initial planned UDS level of $5 \mathrm{mg} / \mathrm{L}$.

b. When the fluidized bed feed system fouled and plugged due to the presence of the heel solids, some of the solids were filtered out of the remaining simulant using a filtering recycle loop for the simulant tank.

c. The RPD indicates differences due to sample analysis results and recipe calculations, and also differences due to the presence of residual heel solids.

d. The measured density values are from the coriolis flow meter.

e. Target $\mathrm{F}$ concentration is half the intended value -- test log indicates $50 \%$ error in simulant makeup.

f. Condition 5.3 included feed w/ and w/o solids. However, mass balances assume 5.3 was entirely w/ solids.

$\mathrm{NM}=$ "not measured". 
Table 4-2. WM-180 heel solids metathesis simulant.

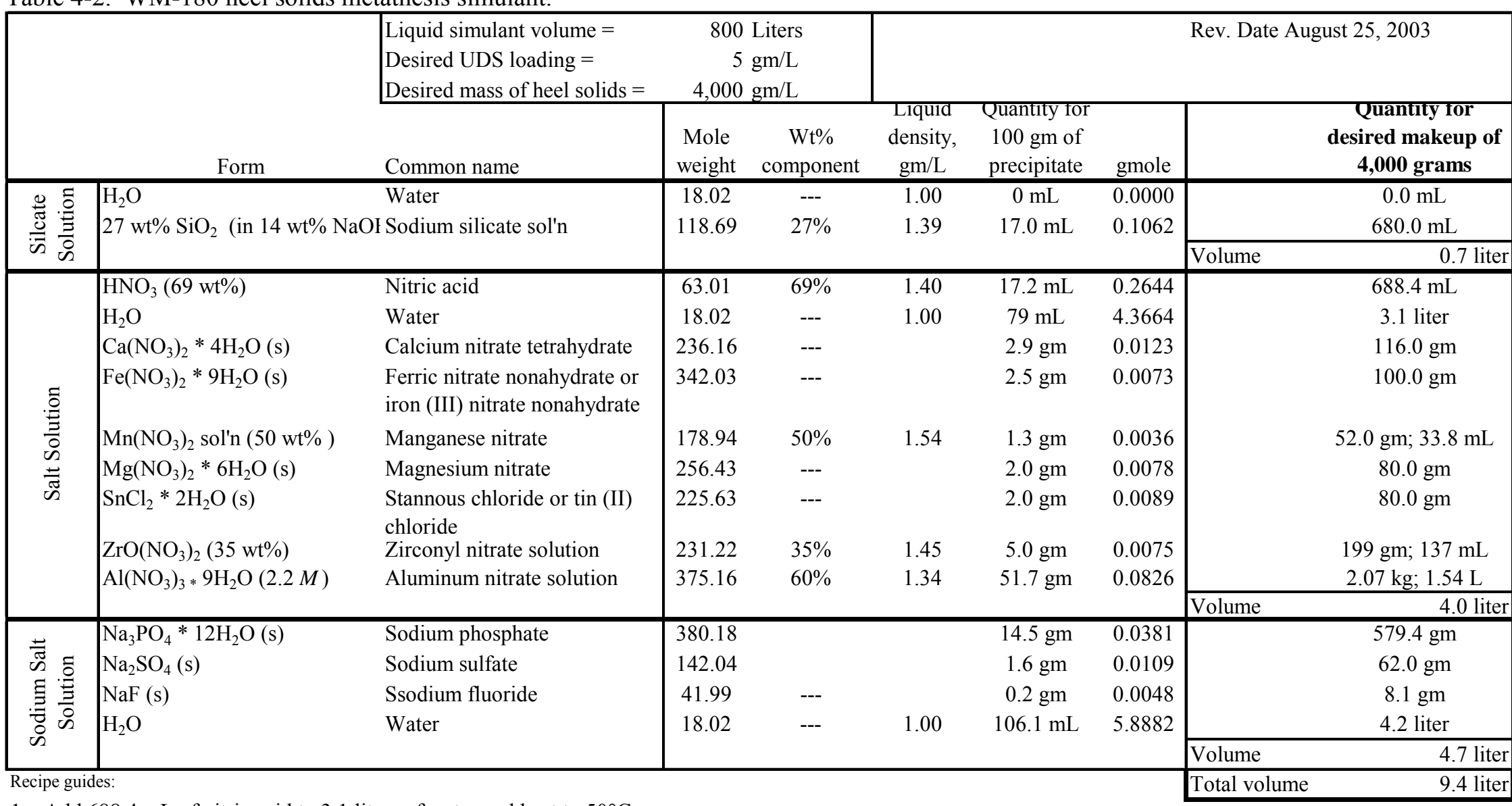

1. Add $688.4 \mathrm{~mL}$ of nitric acid to 3.1 liters of water and heat to $50^{\circ} \mathrm{C}$.

2. Dissolve non-sodium salts in the warm nitric acid solution.

3. Add the zirconyl nitrate and aluminum nitrate solutions to the salt solution.

4. Dissolve the sodium salts in 4.2 liters of water and set the sodium salt solution aside.

5. Dilute the sodium silicate solution with $0.0 \mathrm{~mL}$ of water (as necessary).

6. Stir the salt solution vigorously while simultaneously dribbling in the silicate and sodium salt solutions.

7. Let the slurry stand overnight.

8. Filter and wash the precipitate. (This instruction was not performed because the filtration was so slow.)

Notes: NOx will evolve when some salts are dissolved in the dilute nitric acid. Use a fume hood to mitigate fumes.

1. NOx will evolve when some salts are dissolved in the dilute nitric acid. Use a fume hood to mitigate fumes.

2. The actual amount and composition of solids based on this recipe is not well known. 
The actual amount of UDS in the simulant was further reduced when, in response to feed system plugging, the simulant with added UDS was filtered using a recycle loop. A slipstream of simulant was pumped from the T-1 Simulant Tank through a sock filter and back to the Simulant Tank. The feed system problems are an artifact of the small scale of the feed system. A full-scale feed system designed for feeding a UDS-laden liquid would not experience the plugging problems that occurred during these tests.

The slip-stream simulant filtration activity did not remove all of the UDS, because only a slipstream was filtered. The mass of filtered solids was $0.26 \mathrm{gm}$, about $19 \%$ of the intended amount of 1.34 $\mathrm{kg}$ of solids initially added. The residual UDS concentration was about $1.35 \mathrm{gm} / \mathrm{L}$ of simulant. Table $4-1$ compares the average blended UDS laden composition with the UDS composition calculated by assuming that the full amount of UDS was still in the simulant. 


\section{TEST RESULTS}

Conduct of the tests was in two parts, performed during two test weeks. During the first test week, parametric tests were conducted to determine the more optimal reductant-SBW mass feed ratio, best operating temperature, and the maximum achievable total feed rate that could be sustained given the constraints on heater output and the maximum allowable wall temperature. The heater output is limited to a maximum $12 \mathrm{~kW}$. The reactor wall temperature constraint was set at $680^{\circ} \mathrm{C}$ to limit cesium volatility and to avoid fouling the wall that could occur at higher temperatures. The second week of testing was intended to be a demonstration of the most suitable operating parameters for a period of time sufficient to determine if a stable bed was produced and to determine how the product mass partitioned between the bed and the fines collection systems.

The general philosophy for the operation was that of seeking efficiency in SBW simulant treatment and $\mathrm{NO}_{\mathrm{x}}$ destruction during the parametric tests and to focus primarily on bed particle size control and bed stability during the demonstration test. This afforded the flexibility to explore the limits of operation while keeping gas flow rates relatively constant during most of the parametric tests and to find the limits of operation without being overly concerned with bed particle size control. During the demonstration tests, however, efficiency was devalued in favor of trying to generate seed particles and control attrition to ensure a sustainable mean bed particle size. Particle size management systems, other than using the nozzle atomizing gas flow rate to induce particle attrition, were not incorporated into the test platform.

\subsection{Test Conditions and Observations}

For the parametric tests, the nozzle atomizing ratio (NAR) was intended to be 400 standard liters of $\mathrm{CO}_{2}$ per liter of feed (at 1 atmosphere, $68^{\circ} \mathrm{F}$ ). An artifact of process control logic limited the measured density of the liquid reductant to about $0.9 \mathrm{~g} / \mathrm{mL}$, which resulted in the calculated feed rate of the mixed SBW and IPA to be low. Consequently, the computed atomizing gas mass flow rate was about $10 \%$ lower then would have otherwise been requested. The resulting NAR typically ranged from 330 to 380 , depending on the ratio of SBW to IPA, until the process control logic was corrected.

The fluidizing $\mathrm{CO}_{2}$ flow rate was computed based on the calculated minimum fluidizing velocity for a bed of alumina particles with an absolute density of $3.95 \mathrm{gm} / \mathrm{cc}$ and a mean particle diameter and a multiplier entered into the PLC. The actual fluidizing gas flow rate was typically set several times higher than the flow rate equivalent to the minimum fluidizing velocity to ensure that adequate fluidization was maintained. As bed particles grew from product accumulation, the bed particle diameter and density typically changes. Inputting new bed particle diameter and density data into the PLC would maintain the ratio of the fluidizing gas flow rate compared to the minimum fluidizing gas flow rate, but would cause changes in the flow rate of the main diluent gas $\left(\mathrm{CO}_{2}\right)$ that would make interpretation of the available data more difficult. The fluidizing gas flow rate was typically maintained at a constant value, allowing the fluidizing gas ratio to drift as the bed particle diameter and density changed during operation.

The parametric tests progressed, generally, first to an investigation into the influence of temperature on the performance (Test Series 2), then to the influence on the reductant stoichiometry (Test Series 3), followed by discovering the maximum feed rate (Test Series 1) that could be sustained by the heaters without exceeding the maximum wall temperature. Although a test may have been identified as belonging to a particular test series, some tests served as a datum for more than one parameter.

Table 5.1-1 is a tabular summary of the parametric tests conducted, sorted chronologically rather than numerically. Operating conditions are summarized in Figures 5.1-1 and 5.1-2. 
Table 5.1-1. Summary of test conditions.

\begin{tabular}{|c|c|c|c|c|c|c|c|c|c|c|c|c|c|c|c|c|}
\hline \multirow{3}{*}{\multicolumn{2}{|c|}{ Test \# }} & \multirow{3}{*}{ Start Time } & \multirow{3}{*}{$\begin{array}{c}\text { Duration } \\
\text { hr }\end{array}$} & \multirow{3}{*}{$\begin{array}{l}\text { NAR } \\
\text { SL/L }\end{array}$} & \multirow{3}{*}{$\begin{array}{l}\text { Feed } \\
\text { type }\end{array}$} & \multirow{3}{*}{$\begin{array}{c}\text { Starting } \\
\text { Bed Size }\end{array}$} & \multirow{3}{*}{$\begin{array}{l}\text { Bed } \\
\text { temp. } \\
(\mathrm{T} 4)^{\circ} \mathrm{C}\end{array}$} & \multicolumn{6}{|c|}{ Feed rates } & \multicolumn{3}{|c|}{ Reductant stoichiometry } \\
\hline & & & & & & & & \multicolumn{2}{|c|}{ SBW } & \multicolumn{2}{|c|}{ IPA } & \multicolumn{2}{|c|}{ Total } & \multicolumn{2}{|c|}{ IPA:SBW } & \multirow{2}{*}{$\frac{{ }^{\mathrm{a}} \mathrm{C}:\left(\mathrm{NO}_{3}+\mathrm{O}_{\mathrm{IPA}}\right)}{\mathrm{n}^{*} 100 \%}$} \\
\hline & & & & & & & & kg/hr & L/hr & $\mathrm{kg} / \mathrm{hr}$ & L/hr & kg/hr & L/hr & $\mathrm{kg} / \mathrm{kg}$ & L/L & \\
\hline \multirow{13}{*}{ 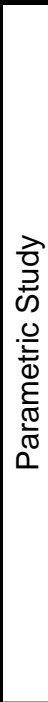 } & 0.1 & 10/20/03 15:30 & $0: 45$ & 324 & \multirow{16}{*}{$\begin{array}{c}\text { SBW + } \\
\text { heel } \\
\text { solids }\end{array}$} & \multirow{13}{*}{$\begin{array}{c}\# 54 \text { grit } \\
(305 \mu \mathrm{m})\end{array}$} & \multirow{2}{*}{581} & 2.0 & 1.6 & 2.8 & 3.6 & 4.8 & 5.2 & 1.41 & 2.18 & 5.4 \\
\hline & 1.1 & 10/20/03 16:15 & $2: 08$ & 358 & & & & \multirow{3}{*}{2.5} & \multirow{3}{*}{2.0} & \multirow{3}{*}{2.4} & \multirow{3}{*}{3.0} & \multirow{3}{*}{4.9} & \multirow{4}{*}{5.0} & 0.95 & 1.49 & 3.7 \\
\hline & 2.1 & 10/20/03 18:23 & $2: 38$ & 371 & & & 596 & & & & & & & 0.96 & 1.51 & 3.8 \\
\hline & 2.2 & 10/20/03 21:01 & $3: 32$ & 366 & & & \multirow{4}{*}{610} & & & & & & & 0.95 & 1.50 & 3.7 \\
\hline & 3.1 & 10/21/03 00:33 & 3:52 & 371 & & & & 3.1 & 2.6 & 1.9 & 2.5 & 5.0 & & 0.63 & 0.96 & 2.4 \\
\hline & 3.2 & 10/21/03 04:25 & $4: 35$ & 382 & & & & 3.7 & 3.0 & 1.5 & 1.9 & 5.2 & 4.9 & 0.41 & 0.63 & 1.6 \\
\hline & 3.3 & 10/21/03 09:00 & 3:01 & 359 & & & & & & 2.9 & 3.6 & & 5.2 & 1.43 & 2.27 & 5.6 \\
\hline & 3.4 & 10/21/03 12:01 & $0: 59$ & 376 & & & 597 & 2.0 & 1.0 & 2.9 & 3.7 & 4.9 & $=0$ & 1.43 & 2.29 & 5.6 \\
\hline & 3.5 & $10 / 21 / 0313: 00$ & 1:00 & 312 & & & 500 & 2.1 & 1.7 & 2.8 & 3.6 & & 0.0 & 1.38 & 2.18 & 5.3 \\
\hline & 3.6 & 10/21/03 14:00 & $1: 00$ & 328 & & & & 2.6 & 2.1 & 2.4 & 3.1 & 5.0 & 5.2 & 0.93 & 1.45 & 3.5 \\
\hline & 1.2 & 10/21/03 21:26 & 14:35 & \multirow{3}{*}{401} & & & 600 & 4.0 & 3.2 & 3.8 & 4.6 & 7.8 & 7.9 & 0.94 & 1.43 & 3.6 \\
\hline & 1.3 & 10/22/03 12:01 & 14:31 & & & & \multirow{2}{*}{596} & 5.0 & 4.0 & 4.7 & 5.7 & 9.7 & 9.8 & 0.95 & 1.43 & 3.7 \\
\hline & 3.7 & 10/23/03 02:32 & $2: 25$ & & & & & 4.4 & 3.5 & 5.1 & 6.2 & 9.5 & 9.7 & 1.15 & 1.75 & 4.5 \\
\hline \multirow{5}{*}{ 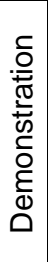 } & 5.1 & $10 / 27 / 0312: 50$ & $2: 00$ & 576 & & \multirow{5}{*}{$\begin{array}{c}\# 80 \text { grit } \\
(165 \mu \mathrm{m})\end{array}$} & 586 & 5 & 06 & 3.9 & 4.8 & 8.4 & 8.4 & 0.86 & 1.33 & 3.4 \\
\hline & 5.2 & $10 / 27 / 03$ 14:50 & $2: 53$ & 435 & & & 500 & 4.5 & 0.0 & 3.5 & 4.3 & 8.0 & 7.9 & 0.77 & 1.18 & 3.0 \\
\hline & 5.3 & 10/27/03 17:43 & 19:14 & 483 & & & & 4.6 & 3.7 & 2.7 & 3.5 & 7.3 & 7.2 & 0.59 & 0.93 & 2.3 \\
\hline & $51^{1}$ & $10 / 30 / 0314.03$ & $\frac{5: 31}{27 \cdot 27}$ & 169 & SBW & & 602 & 52 & 11 & 36 & 16 & 88 & 87 & 070 & 111 & 27 \\
\hline & & 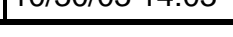 & 21.21 & 469 & & & & 5.2 & 4.1 & 0.0 & 4.0 & 0.0 & 0.1 & 0.10 & & \\
\hline To & & & 109:13 & & & & & $461 \mathrm{~kg}$ & $372 \mathrm{~L}$ & $352 \mathrm{~kg}$ & $439 \mathrm{~L}$ & $813 \mathrm{~kg}$ & $811 \mathrm{~L}$ & & & \\
\hline
\end{tabular}

a. Stoichiometry based on the equation proposed by TWR: $2 \mathrm{C}_{3} \mathrm{H}_{8} \mathrm{O}+2 \mathrm{NaNO}_{3}+\mathrm{CO}_{2} \rightarrow \mathrm{Na}_{2} \mathrm{CO}_{3}+6 \mathrm{CO}+\mathrm{N}_{2}+\mathrm{H}_{2} \mathrm{O}+7 \mathrm{H}_{2}$ 

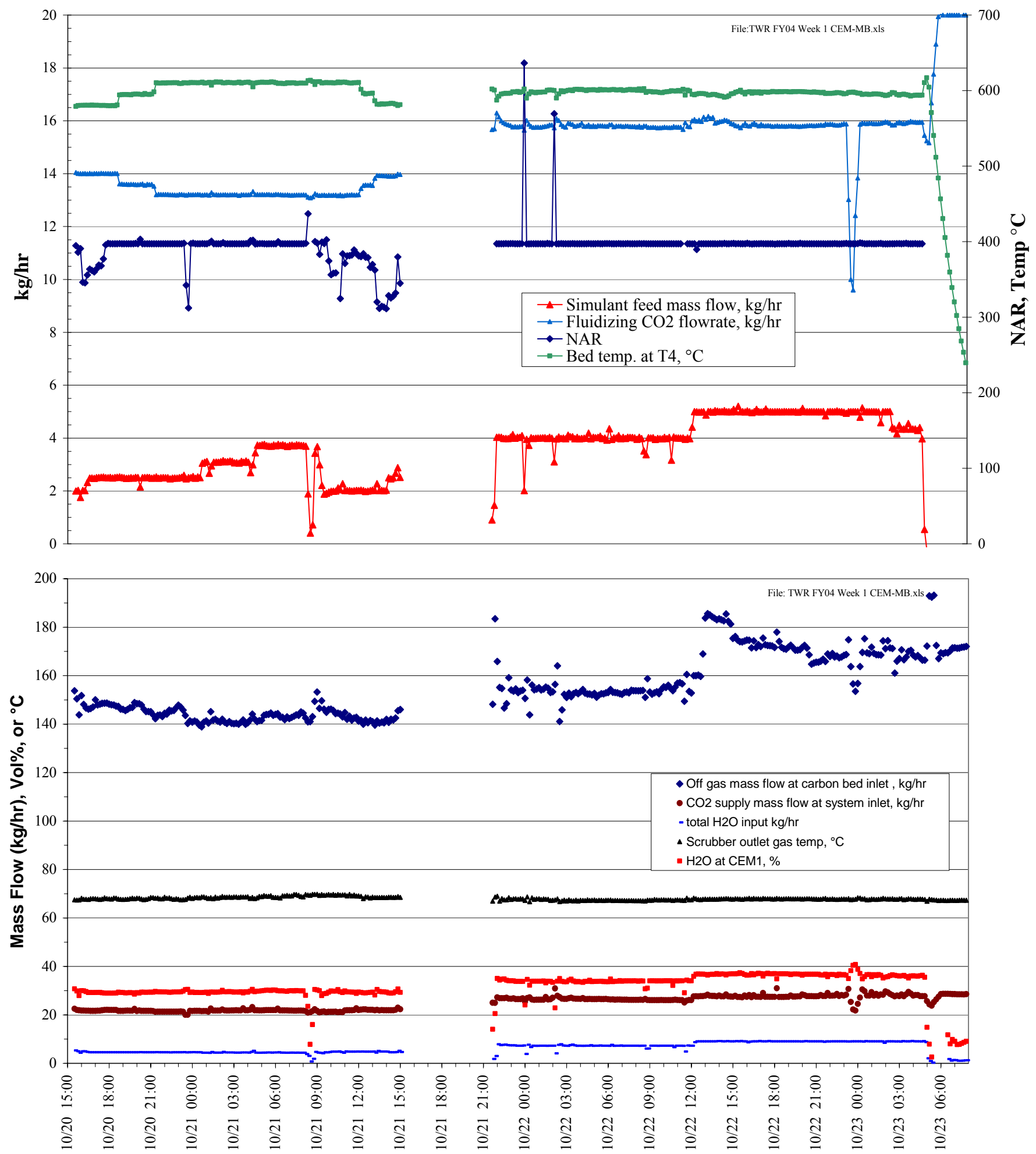

Figure 5.1-1. Operating conditions for the parametric test series. 

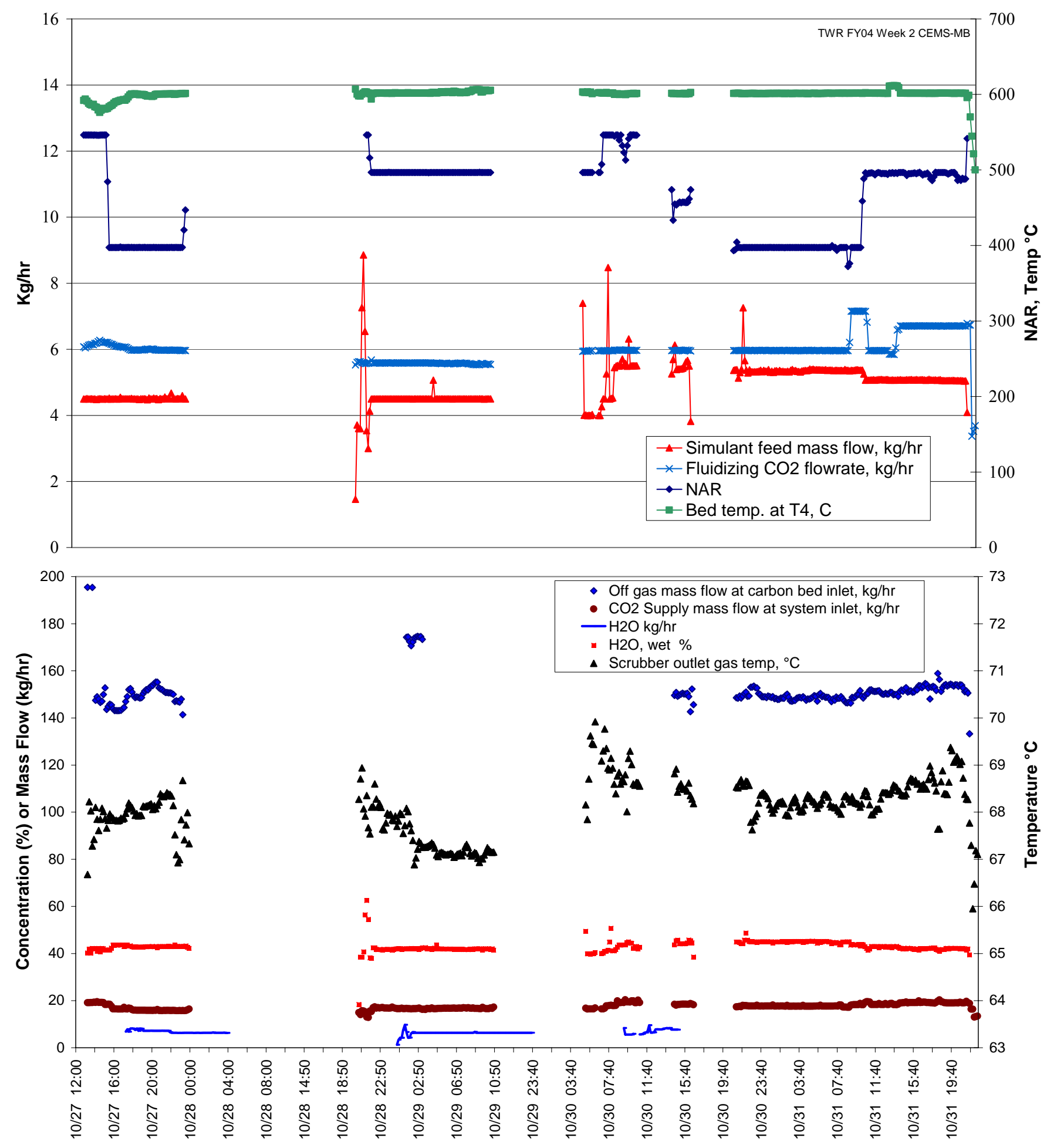

Figure 5.1-2. Operating conditions for the demonstration test series. 


\subsubsection{Summary}

The influence of bed temperature on $\mathrm{NO}_{\mathrm{x}}$ destruction was investigated by varying the bed temperature in $15^{\circ} \mathrm{C}$ increments, from 580 to $610^{\circ} \mathrm{C}$. Offsets in the temperature controller varied with the feed rate to the reformer, which resulted in average processing temperatures differing from the target temperature by a few degrees. Some improvements were observed in the perceived performance of the reformer when temperatures were increased to near $595^{\circ} \mathrm{C}$ (Test 2.1), but little benefit was observed when the temperature was increased to $610^{\circ} \mathrm{C}$. Based on the observations of the instrument panel responses for $\mathrm{NO}$ and methane, a nominal operating temperature of $600^{\circ} \mathrm{C}$ was selected as the target operating temperature for most of the longer-term tests. Post-test reduction of data shows that the $\mathrm{NO}_{\mathrm{x}}$ destruction did improve each time the temperature was increased.

A strong interference was observed in the $\mathrm{NO}$ and $\mathrm{NO}_{2}$ responses when IPA feed was initiated without SBW. $\mathrm{NO}_{2}$ instrument responses were driven strongly negative ( $\sim-500$ to $\left.-700 \mathrm{ppm}\right)$, and the $\mathrm{NO}$ response was $\sim 2,500 \mathrm{ppm}$ when no $\mathrm{NO}_{\mathrm{x}}$ should have been present. Online correction of the readings was not possible for the parametric tests, so judgments were made during the course of each test as to the effects of each change in operating parameters. The NO data were corrected for the interference in posttest data reduction. The $\mathrm{NO}_{2}$ measurements were not used because the amount of the correction was too large compared to the $\mathrm{NO}_{2}$ values.

The overall mass flow rate of the SBW and IPA mixture was maintained near $5 \mathrm{~kg} / \mathrm{hr}$ to minimize the impact of the changes on the heater load and bed temperature. Consequently, as the IPA mass flow rate was decreased, the SBW mass flow was increased. $\mathrm{NO}_{\mathrm{x}}$ reduction at 240\% IPA (Test 3.1) was nearly equivalent to the $\mathrm{NO}_{\mathrm{x}}$ reduction at $160 \%$ IPA stoichiometry (Test 3.2), but $\mathrm{NO}_{\mathrm{x}}$ reduction increased at higher IPA stoichiometries of $360 \%$ (Test 2.2) up to $560 \%$ (Test 3.4). $\mathrm{NO}_{\mathrm{x}}$ destruction ranged from a low of $85 \%$ at the low stoichiometries to a high of $97 \%$ at the high stoichiometries. An IPA stoichiometry of about $360 \%$ was selected as a good operational target to achieve adequate $\mathrm{NO}_{\mathrm{x}}$ destruction while maintaining a reasonably high SBW simulant throughput.

Maximum sustainable feed rates were tested and found to be near $10 \mathrm{~kg} / \mathrm{hr}$ of combined feed (Test 1.3). This was determined with the IPA stoichiometry near $360 \%$ and was measured as the bed temperature slowly decreased over a period of hours, even though the radiant heaters were on continuously and the wall temperature was near $576^{\circ} \mathrm{C}$, just a few degrees from the established maximum.

\subsubsection{Test Conditions and Logic}

Test 0.1 was intended to be a period for conditioning the bed (i.e., coating the bed particles with catalytically active product) and ensuring that the process was operating as planned. The initial IPA stoichiometry was higher than intended (540\% versus 360\%), and the mass ratio of IPA to SBW was adjusted less than an hour into the run. $\mathrm{CO}$, total hydrocarbon (THC), $\mathrm{NO}$, and $\mathrm{CH}_{4}$ concentrations were steady when the change was made.

The change in IPA stoichiometry initiated Test 1.1, which lasted for over 2 hours. Although the IPA stoichiometry and $\mathrm{H}_{2}$ and $\mathrm{CO}$ concentration decreased, the $\mathrm{NO}$ and $\mathrm{CH}_{4}$ concentrations were steady. The decline in $\mathrm{H}_{2}$ and $\mathrm{CO}$ may be attributed to bed conditioning. $\mathrm{NO}_{\mathrm{x}}$ destruction dropped relative to Test 0.1 .

Test 2.1 began when the temperature was increased about $15^{\circ} \mathrm{C}$ to about $596^{\circ} \mathrm{C}$. Other process parameters were held constant. Less fluidizing $\mathrm{CO}_{2}$ was required at the higher temperatures. Although the $\mathrm{CO}_{2}$ diluent decreased, so did the $\mathrm{CO}, \mathrm{H}_{2}$, and $\mathrm{NO}$ concentrations, as the reactions became more efficient and $\mathrm{NO}_{\mathrm{x}}$ destruction increased from $83 \%$ destruction to $86 \%$. After nearly 3 hours, the 
temperature was increased to $610^{\circ} \mathrm{C}$ (Test 2.2) and held for 3.5 hours. THC and $\mathrm{H}_{2}$ increased, and $\mathrm{NO}_{\mathrm{x}}$ destruction increased to $90-95 \%$.

Test Series 3 was part of an effort to determine the approximate IPA stoichiometry that would be required to achieve adequate $\mathrm{NO}_{\mathrm{x}}$ destruction. The incentive to decrease the IPA stoichiometry is not only to reduce the quantity of required additives to treat SBW, but the IPA competes with the SBW for available heat resources, so a decrease in IPA enables a commensurate increase in SBW feed rate. The IPA stoichiometry was decreased by a third, to $240 \%$ stoichiometry, for Test $3.1 . \mathrm{NO}_{\mathrm{x}}$ destruction decreased from about 91 to $85 \%$. The IPA stoichiometry was decreased again to $160 \%$ for Test 3.2 , and $\mathrm{NO}_{\mathrm{x}}$ destruction remained relatively constant.

For Test 3.3, the IPA stoichiometry was increased to $560 \%$. The average $\mathrm{H}_{2}$ concentration increased from about $1.9 \%$ to about $2.5 \%$, and $\mathrm{NO}_{\mathrm{x}}$ destruction increased to $94 \%$. At this stoichiometry, the temperature was reduced in Tests 3.4 and 3.5 to $583^{\circ} \mathrm{C}$. Both decreases resulted in slightly lower $\mathrm{CO}$ and $\mathrm{H}_{2}$ concentrations, and $\mathrm{CH}_{4}$ decreased by $50 \%$, but $\mathrm{NO}_{\mathrm{x}}$ destruction remained relatively constant. Since the NO did not change appreciably when the temperature was dropped, we thought that the IPA stoichiometry exceeded what was necessary and effective in reducing $\mathrm{NO}_{\mathrm{x}}$. Test 3.6 tested this with a reduction in IPA stoichiometry. $\mathrm{CO}, \mathrm{H}_{2}$, and $\mathrm{NO}$ all remained relatively constant at about $97 \%$.

Results of these tests showed that (a) $\mathrm{NO}_{\mathrm{x}}$ destruction was relatively high as long as the $\mathrm{CH}_{4}$ level exceeded about $1.1 \%$ (dry basis), and $\mathrm{H}_{2}$ exceeded about 3\% (dry basis), and (b) higher temperatures generate $\mathrm{H}_{2}$ and $\mathrm{CH}_{4}$ more efficiently, which could lead to reduced IPA requirements.

At the end of test 3.6, the process was shut down because of flow restrictions in the feed nozzle. In order to correct the nozzle plug, the steam reformer had to be drained of bed media and cooled to a temperature at which workers could access, remove, and repair the feed nozzle.

Test 1.2 started with new bed media and an increased bed temperature $\left(600^{\circ} \mathrm{C}\right)$. The IPA stoichiometry was held at $360 \%$ from the previous test. NO concentrations slowly dropped by half during the 14.5 hours of operation, indicative of bed conditioning taking place. $\mathrm{NO}_{\mathrm{x}}$ destruction averaged about $87 \%$. The feed rate was increased again (Test 1.3) to achieve a total feed rate of $9.7 \mathrm{~kg} / \mathrm{hr}$, with no change in IPA stoichiometry. THC, $\mathrm{CO}, \mathrm{NO}$, and $\mathrm{CH}_{4}$ concentrations remained constant, $\mathrm{H}_{2}$ dropped somewhat, and $\mathrm{NO}_{\mathrm{x}}$ destruction remained about $87 \%$, even though the simulant feedrate was increased. At $600^{\circ} \mathrm{C}$ and a total feedrate of $9.7 \mathrm{~kg} / \mathrm{hr}$, the bed temperature could not be easily maintained because the bed heaters were at nearly full duty.

After another 14.5 hours of operation, the IPA stoichiometry was increased to $450 \%$ (Test 3.7 ). Off-gas concentrations were essentially unchanged. This test terminated after nearly 3 hours due to a second feed nozzle plug. The average $\mathrm{NO}_{\mathrm{x}}$ destruction edged downward to $86 \%$.

\subsubsection{Flow Sheet Demonstration}

After the first week of testing, TWR desired to keep the bed well fluidized to facilitate heat transfer, and they wanted to limit the fluidizing gas velocity so that gas residence time could be enhanced. TWR recommended charging the bed with 80 -grit media rather than the 54-grit media used during the parametric tests. Accordingly, the smaller media was charged to the reformer.

Some parametric test conditions were yet untried, so the first part of the second week was devoted to further parametric testing while the bed conditioned. These included brief ( 2 and $3 \mathrm{hr}$ ) runs at differing IPA stoichiometries. 
The emphasis shifted during the second week of testing from fine-tuning the chemistry to particle size control. Rather than attempting to keep feed streams and fluidization velocities constant to facilitate interpretation of the raw instrument data, it became more important to control particle growth and attrition mechanisms and to successfully run for an extended period. The nozzle atomizing gas flow rate was adjusted in an attempt to induce increased particle attrition to control particle growth and produce seed particles.

5.1.3.1 Summary. Because of frequent feed nozzle plugging problems during the parametric tests, which was thought to have been caused by coarse particles in the simulated heel solids, 300 and $100 \mu \mathrm{m}$ sock filters were installed on the feed tank recirculation lines to capture some of the larger particles. Eventually, the tanks were allowed to settle. Much of the heel solids were so finely divided that they remained suspended in the liquid. The exact quantity of remaining solids was unknown at the time of the test. When these efforts did not sufficiently ameliorate the plugging problems, the SBW simulant feed was switched to a WM-180 simulant without heel solids.

After efforts had been made to reduce suspended and entrained solids in the SBW simulant, it became apparent that the IPA was responsible for much of the plugging. Even though the IPA was $>99 \%$ pure food-grade IPA, white-colored precipitation had formed in the drums supplied by the manufacturer. The IPA was stored outside of the building, and precipitation may have occurred due to unseasonably cold temperatures. The IPA solids plugging problem was resolved by adding a filter to the dip tube in the IPA barrel.

5.1.3.2 Test Conditions and Logic. Test 5.1 began at $600^{\circ} \mathrm{C}$, with a total feed rate of about 9.8 $\mathrm{kg} / \mathrm{hr}$ and $340 \%$ IPA stoichiometry. The bed temperature could not be maintained at this feed rate, so the IPA feedrate was reduced to $300 \%$ stoichiometry. The temperature stabilized near $586^{\circ} \mathrm{C}$. Ultimately, the feed rate was reduced to $8.4 \mathrm{~kg} / \mathrm{hr}(4.5 \mathrm{~kg} \mathrm{SBW} / \mathrm{hr})$ and an average IPA stoichiometry of $340 \%$. After 2 hours, Test 5.2 was started at a total feed rate of $8 \mathrm{~kg} / \mathrm{hr}$ and $300 \%$ IPA stoichiometry. Off-gas concentrations remained steady. $\mathrm{NO}_{\mathrm{x}}$ destruction averaged about $83 \%$.

After 3 hours, Test 5.3 conditions were established by increasing the bed temperature to $602^{\circ} \mathrm{C}$ and reducing the IPA stoichiometry to $230 \%$. $\mathrm{NO}_{\mathrm{x}}$ destruction rose to $92 \%$. This test was interrupted by plugged feed lines and coriolis meters, but the problems were quickly resolved, and the system brought back on-line until a bed agglomeration caused another system shutdown. The agglomerations may have been caused by feed surging as nozzle restrictions were cleared. The automatic controls on the feed pumps occasionally allow surges of feed into the bed when the feed nozzle plugs and then the plug clears.

Part way through Test 5.3, the SBW feed was switched to left-over feed from the tests performed in Phase 1, which did not contain any heel solids. After that switch, the cause of the nozzle plugging was found to be precipitated solids in the IPA. $\mathrm{NO}_{\mathrm{x}}$ destruction averaged near $91 \%$.

Test 5.4 was started with about one day of operating time remaining. The IPA line became restricted again with the white solids. After the line was cleared, a filter was installed on the inlet to the suction line from the drum to filter out the solids. The average IPA stoichiometry was $270 \%$, and the average feed rate was $8.8 \mathrm{~kg} / \mathrm{hr}(5.2 \mathrm{~kg} \mathrm{SBW} / \mathrm{hr})$. Off-gas constituents remained essentially unchanged from the previous conditions. $\mathrm{NO}_{\mathrm{x}}$ destruction averaged about $93 \%$ for Tests 5.3 and 5.4.

\subsection{Solid Product Evaluations}

The feed solution, when sprayed into the bed, undergoes evaporation, thermal decomposition, and other reactions that denitrate the feed and volatilize some of its components. The solid residual products of the steam reforming process either stay in the bed or elutriate from the bed with the off-gas, depending on operating conditions and properties of the bed media and solid products. If the solid products form 
durable coatings on existing bed particles, then the products tend to stay in the bed. With continued operation under these conditions, the bed mass would grow, necessitating eventual removal of some of the bed material. Most of the steam-reformed product would be in the form of bed media drained from the bed.

If the solid products tend to form new, small particles, or fragile coatings on bed particles that readily spall, they would be easily entrained in the fluidizing gas and would tend to elutriate from the bed. This mode of operation would tend to leave the bed particles intact and result in elutriated product being captured in the cyclone and filter.

Operating practice could include choosing conditions to erode bed particles, control their size, and/or to elutriate product. Alternatively, other operating modes could include recycling elutriated fines back to the fluidized bed to maximize the production of coarse particles and minimize the net output of elutriated fines. This mode was not utilized during the TWR process optimization tests. All elutriated fines captured in the cyclone were segregated into a separate product stream, as were the elutriated fines that passed through the cyclone and were captured on the sintered metal filters.

\subsubsection{Solid Product Distribution and Mass Balance Closure}

The solid product distribution and mass balance closure are shown in Table 5.2-1. The total input masses were the starting bed media and solid material from the reformed SBW feed. Output masses included the bed product, cyclone catch, filter catch, scrubber solids, and off-gas. Portions of each of these three product streams were extracted as samples for characterization and were separately accounted. Bed product was removed (a) at the end of each week of testing and during some shutdowns when the entire bed was removed, and (b) through the course of each test as excess bed (i.e., bed material was removed to maintain a constant bed depth. Bed depth varied as a result of changes in the density of the bed particles and/or accumulation of unelutriated product in the reformer vessel).

Only the results from the second week of testing are shown in Table 5.2-1, due to the fact that only the second week's product samples were chemically analyzed. To maintain consistency with the elemental mass balances (presented later), the overall mass balance therefore includes only the period covered by the analytical results. The mass balance accounts for shutdowns during the week in which the bed was dropped from the reformer vessel and later re-used. Consequent changes in starting bed composition from that of virgin bed material were incorporated.

Subtracting the mass of re-used bed media $(24 \mathrm{~kg})$ from the total bed product, the total bed turnover [(net product mass)/(mass of virgin bed material)] was about 1.7 . On average, about $50 \%$ of the bed product was newly formed product from the simulant feed.

\subsubsection{Bed Building and Product Elutriation}

The solid product mass distribution between the bed product and filter fines indicates that the feed solids partitioned mostly to the bed product. As the simulant feed was fed to the reformer, the feed solids tended to coat the bed particles rather than form separate small particles that would be elutriated from the bed. The sizes of the bed particles continued to grow. Bed media was periodically drained from the bed to maintain a target bed depth (indicated by continuous measurements of fluidized bed density and bed height) of about 30-35 inches. As the bed particles grew in size, the bulk and particle densities decreased because of lower packing factors and lower particle densities of the carbonate product compared to the starting alumina bed media. 
Table 5.2-1. Solid product distribution and mass balance closure for the TWR test series week 2.

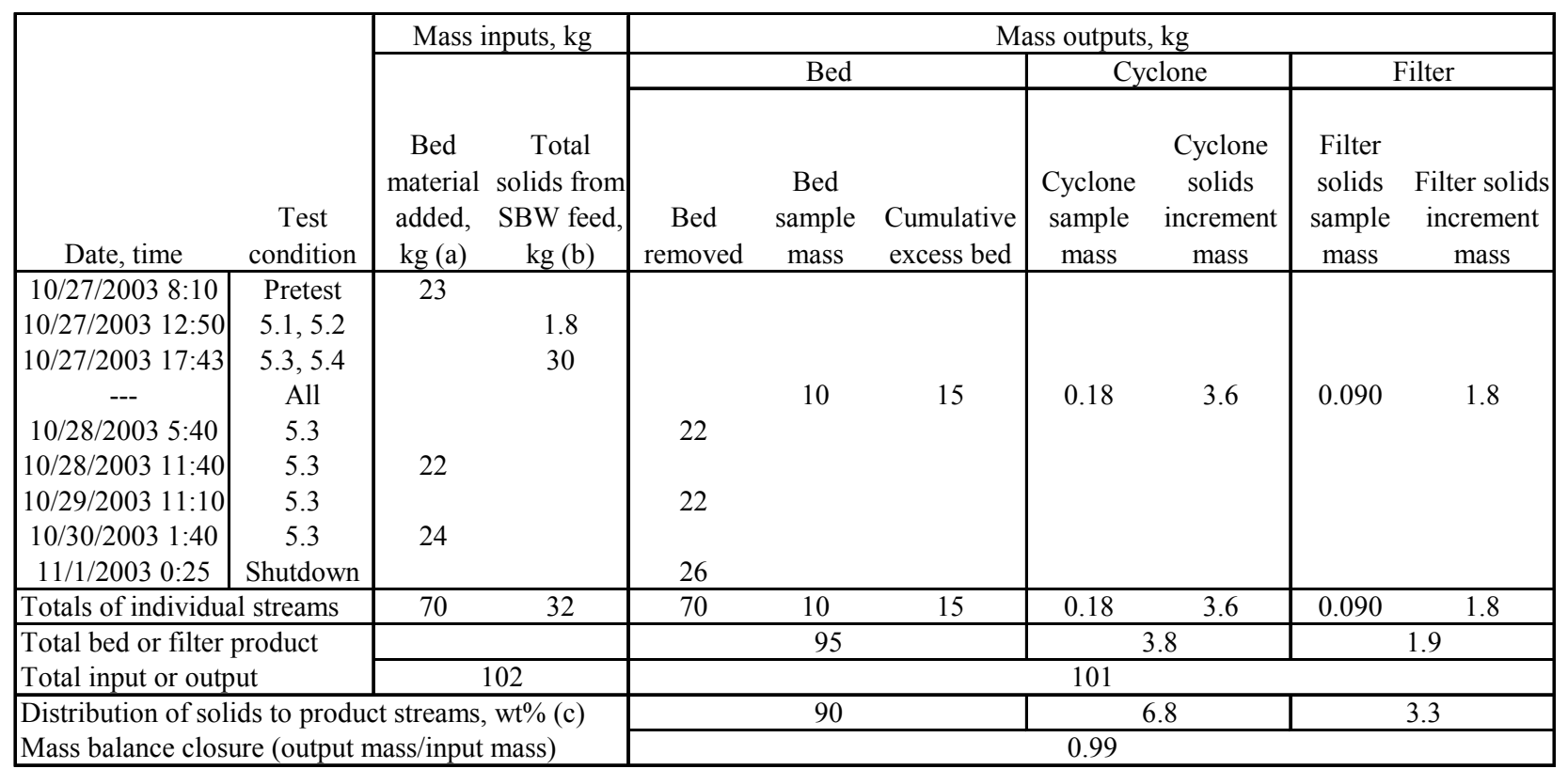

a. This mass balance is only for th second test week.

b. Total SBW solids was estimated from the calculated amount of solid product per liter of feed $(0.15 \mathrm{~kg} / \mathrm{L})$ and the total SBW feed volume for the week.

c. Percentage of total product mass in bed, cyclone, and filter products.

d. Percentage of the total product mass in each of the three solid product streams. In this calculation the mass of the bed product stream was reduced by the mass of the virgin bed material that was fed to the reformer (first two bed material addtions only).

[total solids mass bal for TWR (ddt).xls]Sheet1

Figure 5.2-1 shows that as the bed height was maintained near the top of target range, the fluidized bed density decreased from about $1.6 \mathrm{gm} / \mathrm{cc}$ to about 1 . These measurements were made using pressure taps located in the bed to measure the total fluidized bed pressure drop, and the fluidized bed pressure drop for a given 13-inch bed depth.

\subsubsection{Solid Product Characterization and Particle Size}

5.2.3.1 Bed Product. Scanning electron micrographs (SEMs) of the solid bed product particles are shown in Figure 5.2-2. The figure shows samples from different times through the 2 weeks of testing. The parenthetical parameter cumulative feed (CF) indicates the cumulative SBW simulant fed to the reactor since virgin bed was installed in the reactor. Also indicated is the test condition at the time the sample was taken. Virgin bed was installed at the start of both the first and second weeks of testing. Thus, the bed was replaced between Samples 70 and 127, and also between Samples 127 and 158. The bed growth from virgin material (Sample 7) through the first week of testing (Sample 70) is apparent in the SEMs. The same trend is also seen for the second week in Sample 127 through 197. Also apparent is the change in the surface characteristics of the particles as reaction products from the feed accrete onto the particles. The surface accretions are very evident when one compares the virgin bed (Sample 7) with Sample 197. 


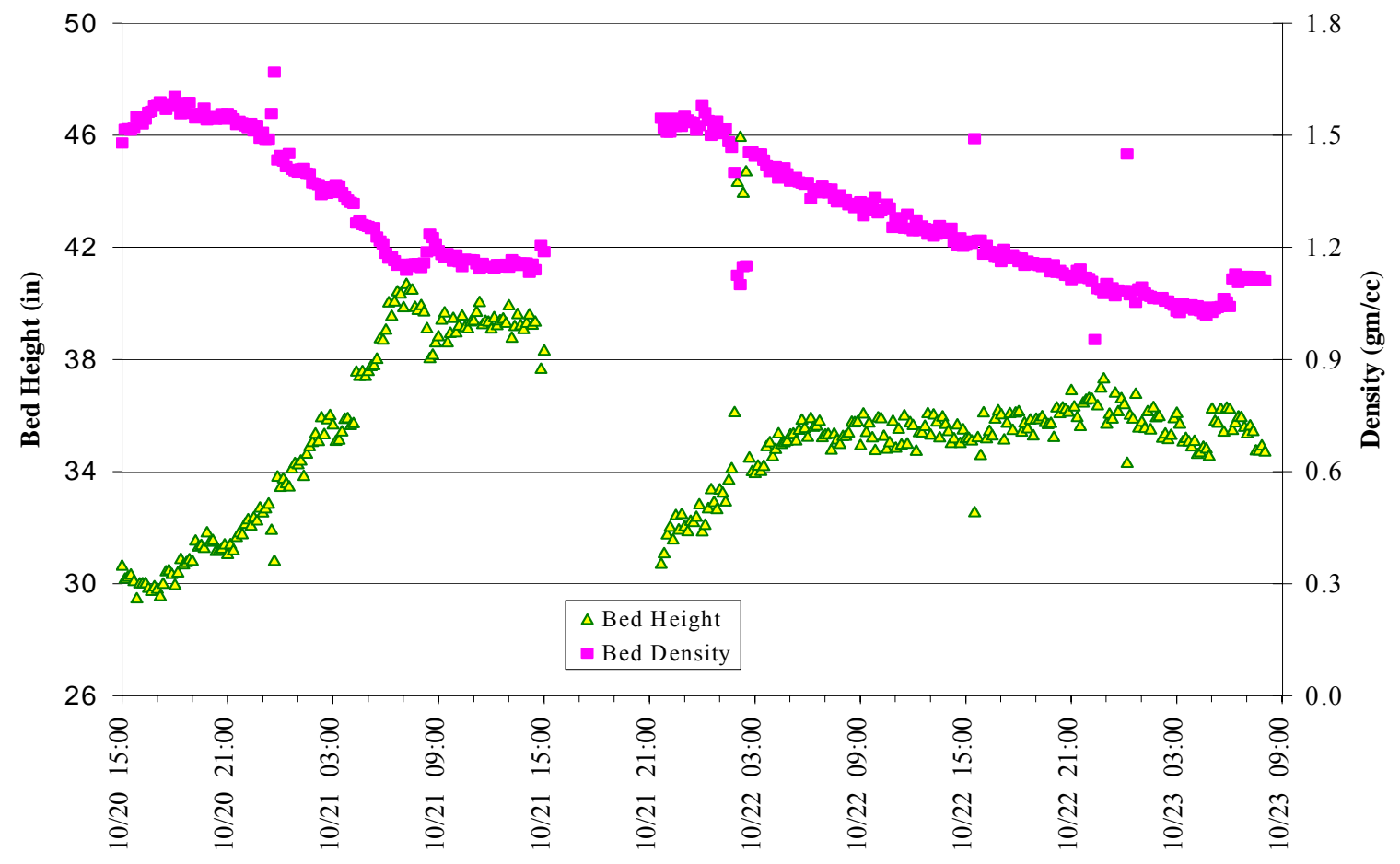

Figure 5.2-1. Continuously measured in situ bed depth and mass for the first TWR test week.

One of the test objectives was to obtain a stable bed. In stable operation, the bed mass, density, height, particle size, and product distribution would be controlled within acceptance limits. New solid bed mass generated from the feed may be either elutriated as solid product with no loss of the starting bed medium, or the new mass may stay add to the bed particles. Under the first scenario, the starting bed acts as a catalyst (and/or heat transfer medium) to facilitate the conversion of feed materials to products with little or no change to the starting bed. This conversion may be achieved either with the entering feeds reacting among themselves, with occasional contact with the starting bed, or with the entering feeds becoming temporarily an integral part of the starting bed particles until the desired reactions have been completed, at which time the product materials spall off the starting bed particles and are eventually elutriated from the reactor. This process is dynamic in that the starting bed is continually gaining and losing mass as the feed materials enter, react, spall, and then elutriate. Ideally, an equilibrium condition is reached where the average composition and particle size distribution (PSD) of the entire bed become static.

Under the second scenario, the new feed product adds to the bed particles with less elutriation. Product material is removed at least in part as bed product. Eventually the feed product replaces the starting bed media. Either of the above scenarios will eventually produce a stable bed. 


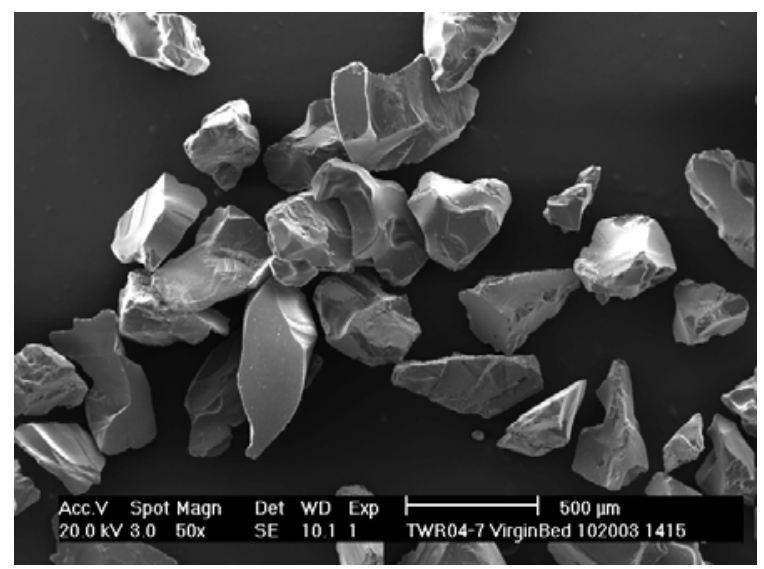

Sample 7 (0 kg CF-virgin bed)

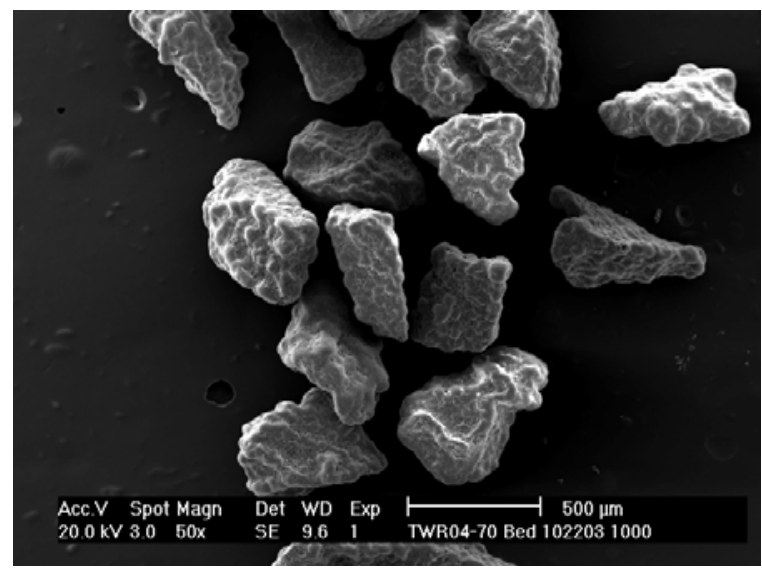

Sample 70 (123 kg CF, Test Condition 1.2)

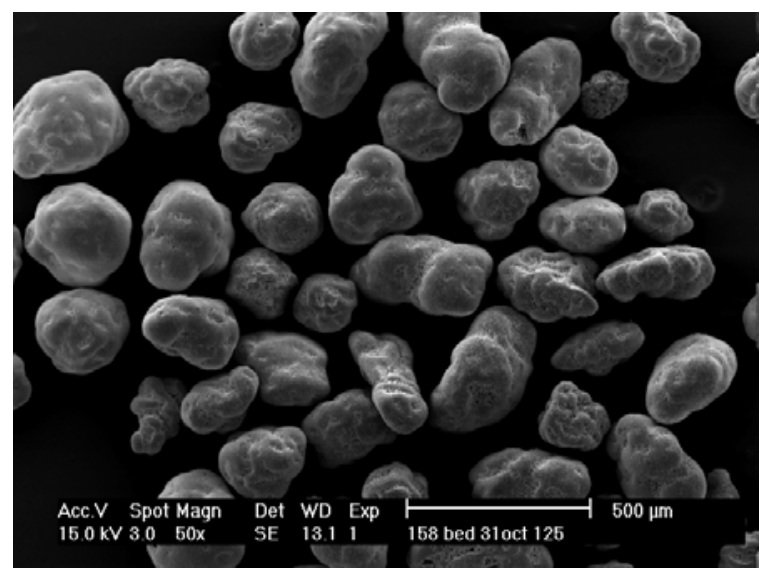

Sample 158 (173 kg CF, Test Condition 5.4)

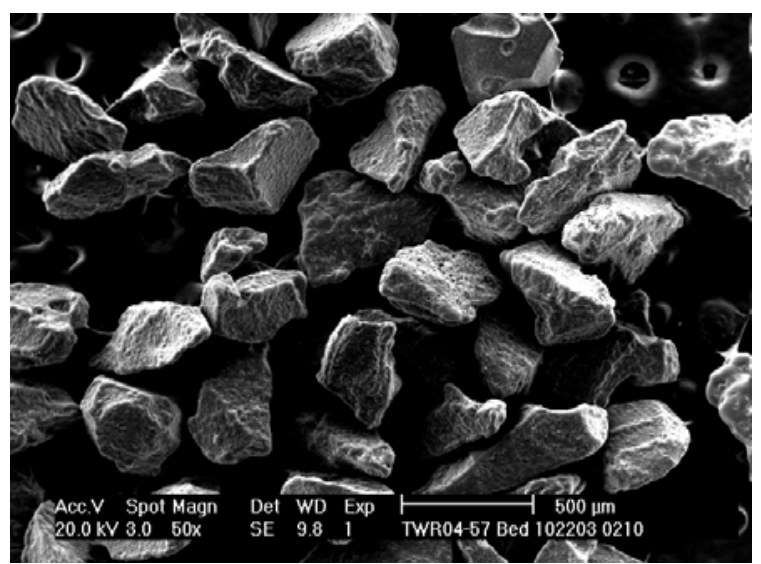

Sample 57 (92 kg CF, Test Condition 1.2)

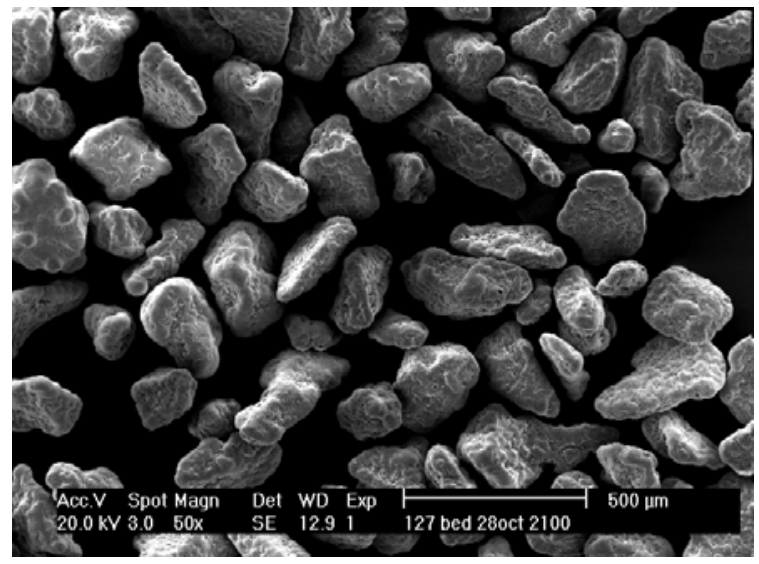

Sample 127 (37 kg CF, Test Condition 5.3)

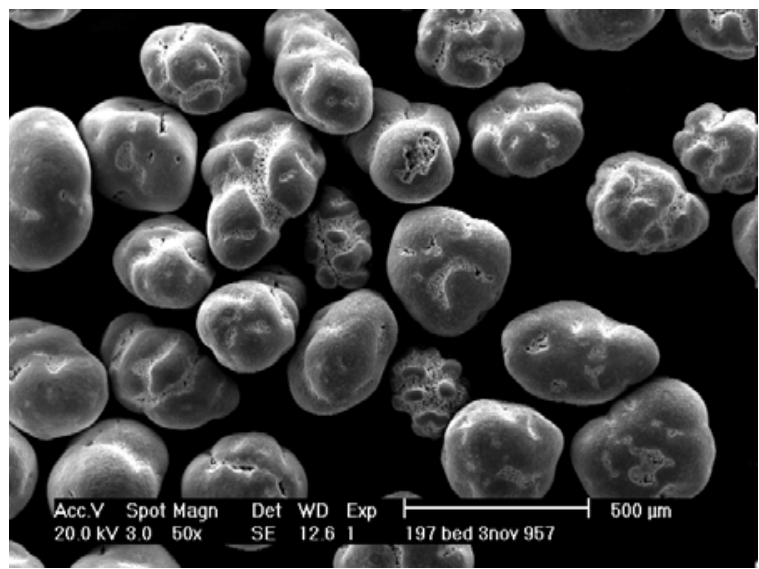

Sample 197 (277 kg CF, Test Condition 5.4)

Figure 5.2-2. SEMs of bed product at various cumulative feed amounts. Note that virgin bed (Sample 7) was placed in the reformer at the start of testing and also between the first and second weeks (i.e., before Sample 127). 
The degree to which a stable bed was achieved is indicated in part by bed product characteristics and particle size distribution and mean size. The bed particle size distribution was determined by sieve analysis using standard screen sizes. The resulting mass and harmonic mean particle diameters (MMPD and HMPD) are shown as functions of the cumulative SBW simulant fed during the second week of testing only, in Figure 5.2-3. The mean particle size during this test period varied between about 0.18 and $0.30 \mathrm{~mm}$, nearly doubling in size. A stable bed was not achieved during the course of the test, as the mean particle diameter shows a monotonic increase, consistent with visual observations from the SEMs.

The dynamics of bed growth are further illustrated in the 3-D histogram shown in Figure 5.2-4. In this figure, the z-axis (into the page) indicates the chronological order in which the bed samples were taken during the second week of testing; the $\mathrm{x}$-axis (across the page) indicates the approximate midranges of the particle size classes (in $\mathrm{mm}$ ); the y-axis (up the page) gives the percentage of the total sample mass which was found in the respective size classes. The PSDs of samples collected early in the run are those closest to the reader and those collected late are furthest. In this representation, one can observe the migration of bed mass from the smaller into larger bed particles. For example, early in the run, the peak in mass distribution was in the $0.164-\mathrm{mm}$-size class, with virtually no bed mass in particles above $0.274 \mathrm{~mm}$. Late in the run, however, the mass in the $0.164-\mathrm{mm}$-size class disappeared, and the peak in the mass distribution moved to the 0.274- and 0.326-mm classes, with some bed mass moving into still larger particles $(0.388$ to $0.653 \mathrm{~mm})$.

Additional qualitative information about the nature of the bed product formed is provided by the optical microscope photographs shown in Figure 5.2-5. The figure shows two backlit views of intact bed product particles. These views are actually composites of many photos taken at different focuses (depths of field) to allow the entire surface of the three-dimensional particle to be viewed clearly. The photos illustrate both the color and the translucent character of the bed product. Evident from these photos (and also the SEMs in Figure 5.2-2) is the disappearance of the sharp, angular edges of the virgin bed material seen in the upper left SEM of Figure 5.2-2. Noticeably absent from the photos in Figure 5.2-5 are shadows or outlines of the parent bed particles.

In Figure 5.2-6, SEMs of the bed product are provided at 50x to 20,000x magnifications, with insets in each view showing the portion of that view shown at the next higher magnification. Scale bars are also provided in all figures. Proceeding from upper left across the page and then down one can see the different scales at which the particle formation processes proceed. The second figure $(350 \mathrm{x}$ magnification) shows what appears to be polishing of the outer surface as the particles rub against each other in the bed. The cracks in the surface provide fissures that are not polished by contact with other bed particles.

Many submicron crystalline particles (lower left SEM, 2000x magnification) are visible in the fissures present in the SEM. The submicron particles may show what the solid residues of the feed look like when unexposed to polishing or grinding against other particles in the bed. At the smallest scale, it is evident that distinct physical processes were occurring at scales as small as $0.1-0.2 \mu \mathrm{m}$, as evidenced by the smallest particles. The smallest particles are not spherical, in contrast to other flow sheets that have been tested (Soelberg 2004). 


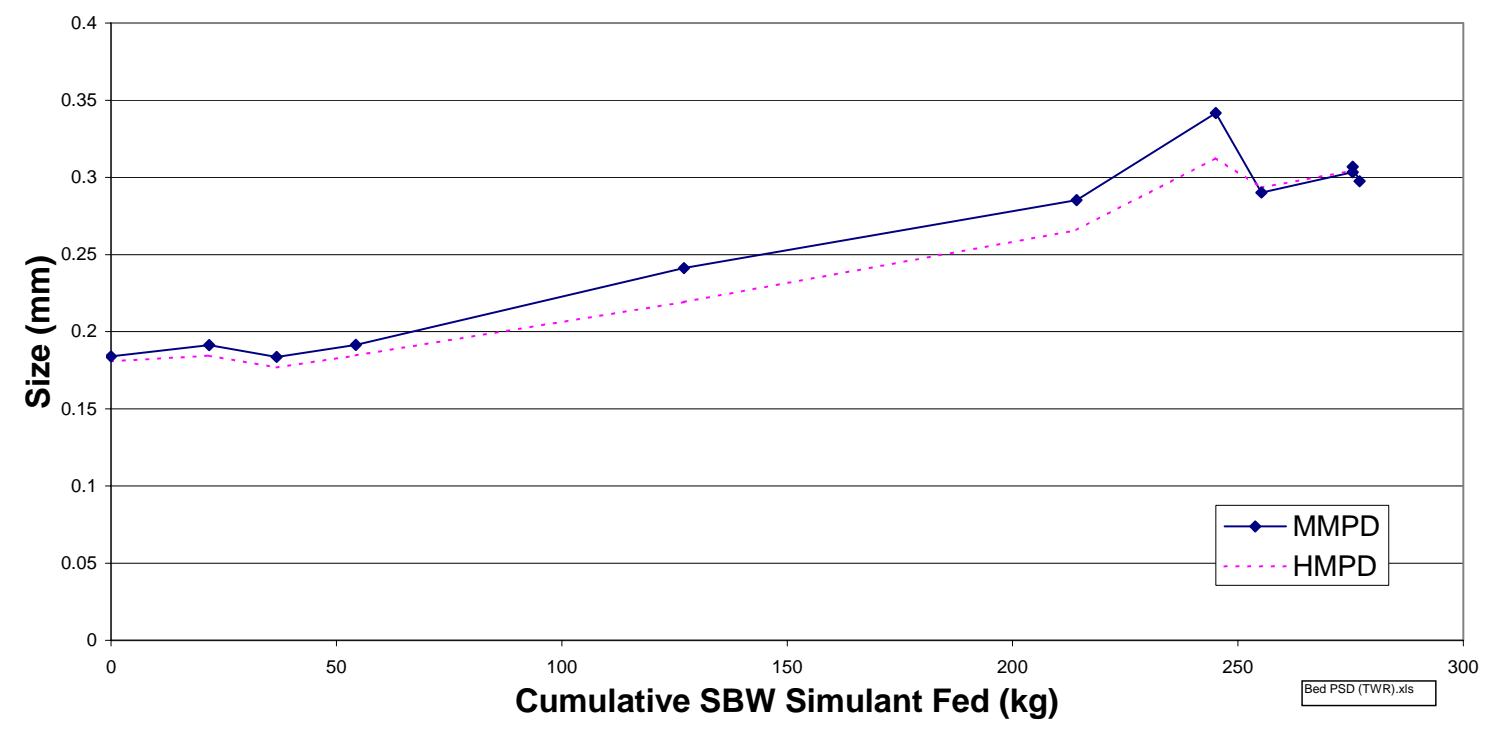

Figure 5.2-3. Mass and harmonic mean bed product particle diameter versus cumulative SBW fed.

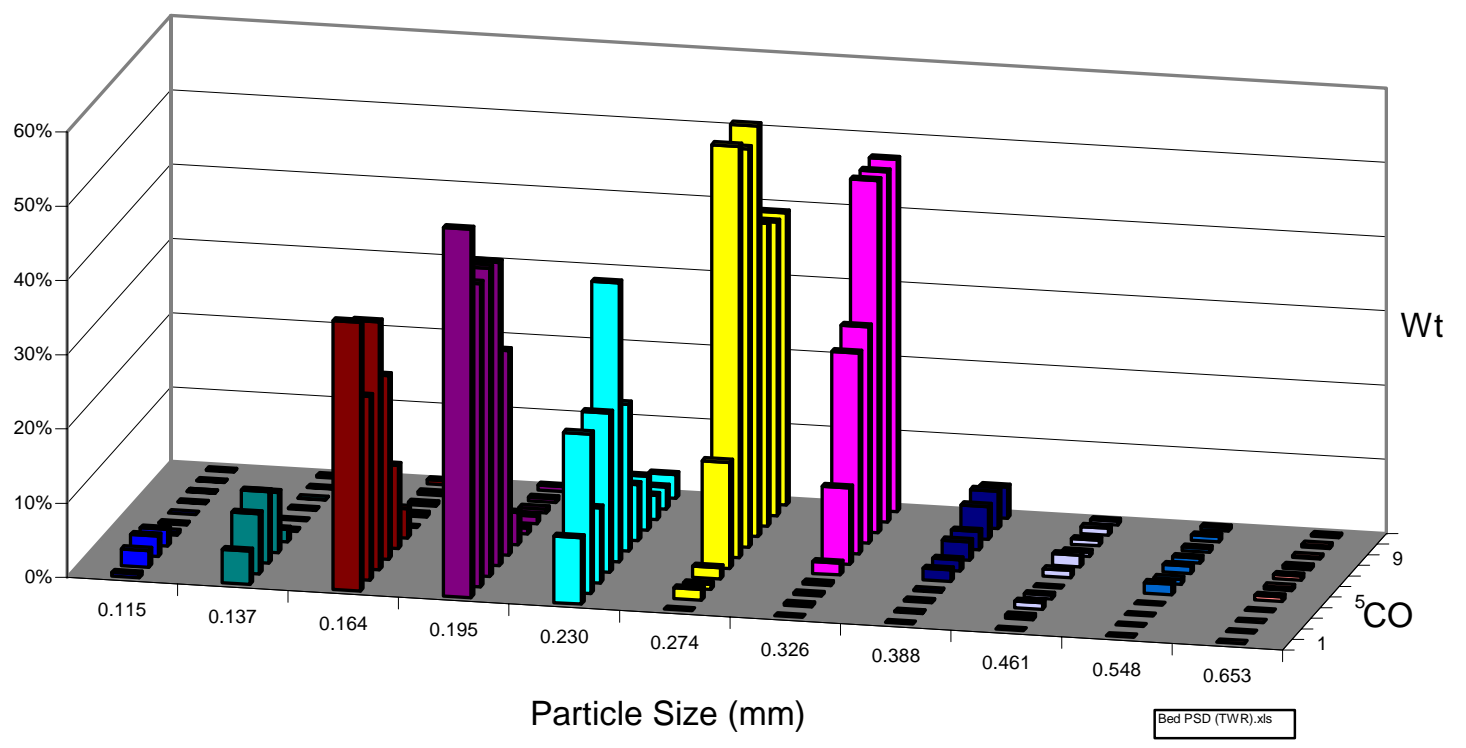

Figure 5.2-4. Mass fraction in various size ranges versus COT. (Note that the COT axis is not linear. COT value indicates only the chronological order in which the samples were drawn through the run.) 

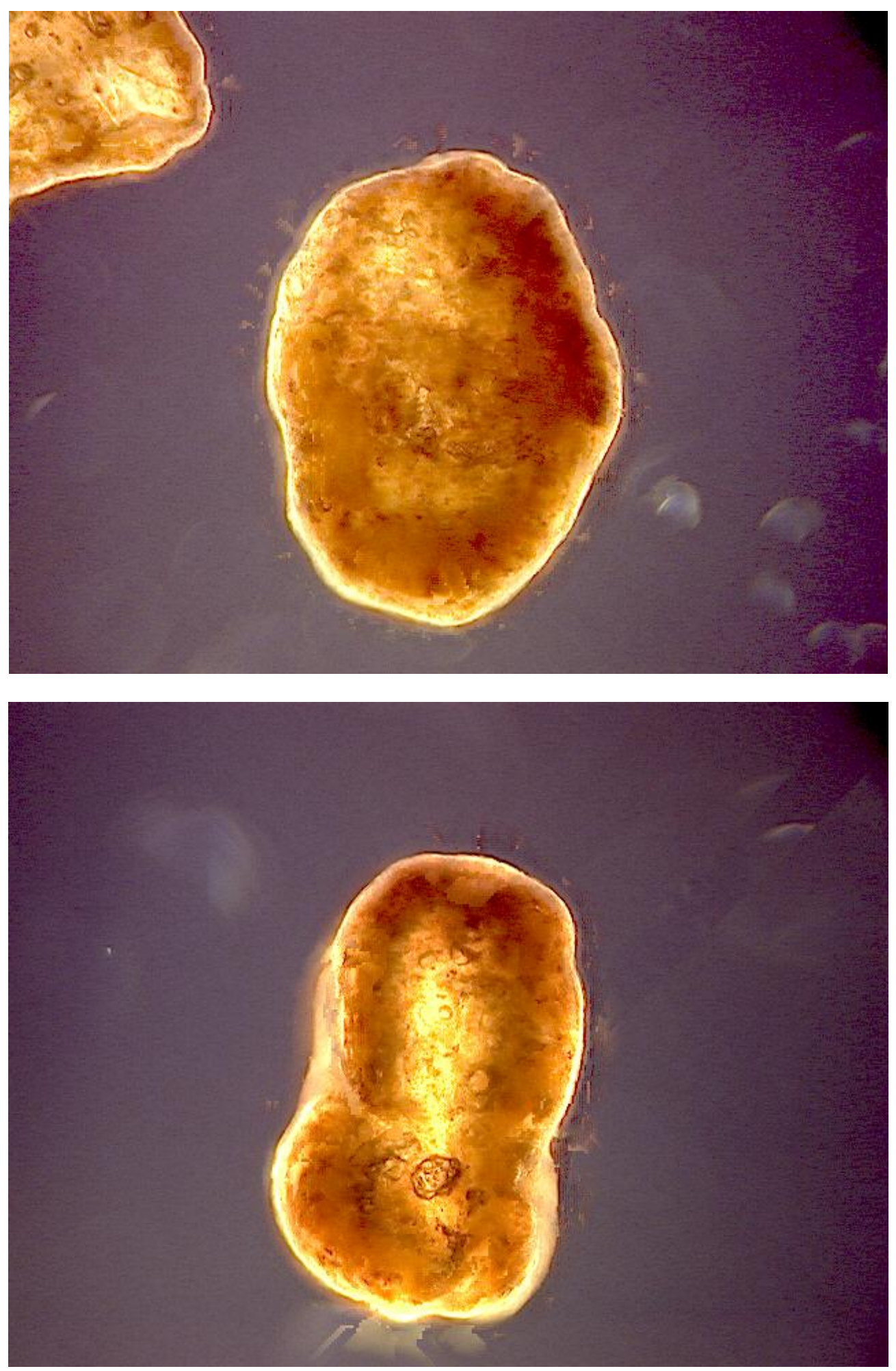

Figure 5.2-5. Optical microscope photographs (backlit) of bed product particles from Sample 153 for TWR flow sheet. The figures are composites, which combine focused images at multiple depths of field, allowing one to view the entire 3-D surface of the particle in focus. 

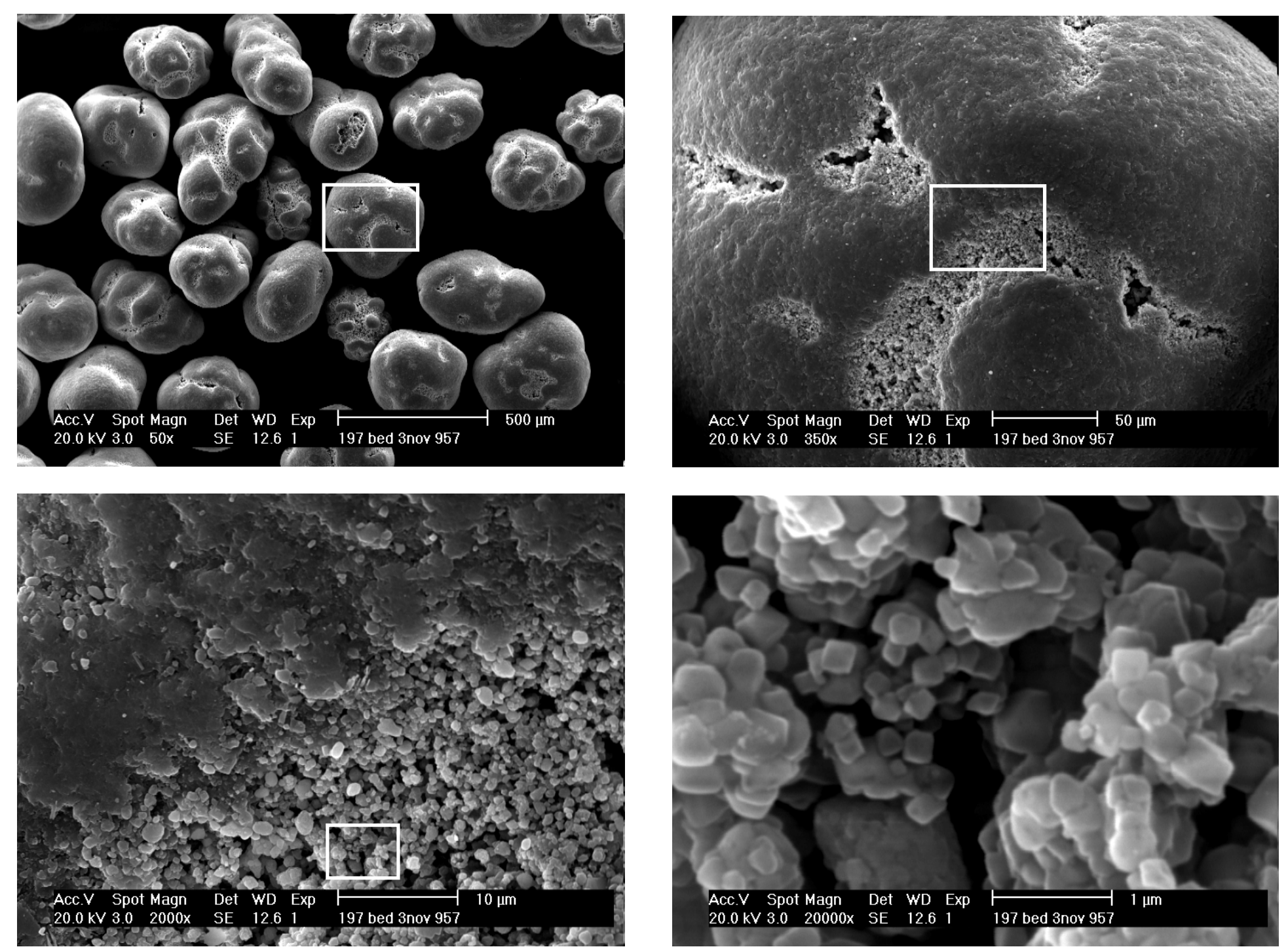

Figure 5.2-6. SEMs of TWR flow sheet bed product, sample 197 (Test condition 5.4). Scale decreases from left to right and top to bottom. Insets show field illustrated at next lower scale to right or below. 
Additional useful information about the nature of the bed particles was obtained by periodic determination of individual particle densities and of overall (bulk) densities of the aggregated product. These parameters were measured by weighing a bed sample, measuring its volume in a graduated cylinder, and then determining the mass of liquid hexane required to barely fill the void spaces between particles in the graduated cylinder. The individual particle densities were then calculated by subtracting the volume of hexane from the bulk volume of the particles. In these determinations, it was presumed that the bed material would be totally insoluble in the hexane.

Bed particle and bulk densities are shown in Table 5.2-2. The bed particle density and bulk densities decreased throughout the test (except the first particle density in the table, which may be anomalous), again indicating that a stable bed condition was not achieved. The fractional change in the bulk density $(\sim 28 \%)$ was only slightly higher than that of the particle density $(\sim 24 \%)$.

Table 5.2-2. Bed product bulk and particle densities for the TWR test series.

\begin{tabular}{|c|c|c|c|c|c|}
\hline Sample & Date & Test Cond & $\begin{array}{c}\text { Cumulative } \\
\text { SBW Fed }(\mathrm{kg})\end{array}$ & Particle Density (g/cc) & Bulk Density (g/cc) \\
\hline 44 & $10 / 21 / 034: 00$ & 3.3 & 59 & 3.05 & \\
\hline 62 & $10 / 22 / 036: 30$ & 1.2 & 109 & 3.54 & \\
\hline 70 & $10 / 22 / 0310: 00$ & 1.2 & 123 & 3.46 & \\
\hline 78 & 10/22/03 14:00 & 1.3 & 141 & 3.36 & \\
\hline 85 & $10 / 22 / 0318: 00$ & 1.3 & 161 & 3.27 & \\
\hline 91 & $10 / 22 / 0322: 00$ & 1.3 & 181 & 3.11 & \\
\hline 99 & 10/23/03 2:00 & 1.3 & 201 & 2.9 & \\
\hline 101 & 10/23/03 7:00 & 1.4 & 212 & 2.93 & \\
\hline 110 & $10 / 27 / 036: 15$ & 1.4 & 0 & 3.74 & \\
\hline 121 & $10 / 27 / 0317: 40$ & 5.2 & 22 & 3.65 & 1.92 \\
\hline 127 & 10/28/03 21:00 & 5.3 & 37 & 3.41 & 1.79 \\
\hline 153 & 10/30/03 9:00 & 5.4 & 127 & 3.18 & 1.48 \\
\hline 173 & 10/31/03 9:00 & 5.4 & 214 & 2.85 & 1.37 \\
\hline
\end{tabular}

\subsubsection{Cyclone and Filter Solids}

[Auxilliary TWR data.xls]Solid Density-TWR

In Figures 5.2-7 and 5.2-8, SEMs of the solid cyclone and filter solids are presented at magnifications similar to those in Figure 5.2-6. Scale bars are also provided. The 50x magnification SEMs in the upper left of each of the three figures may be directly compared to see the gross differences in particle sizes of materials collected in the three process locations (bed, cyclone, and filter). The 50x view in Figure 5.2-7 shows that a very broad spectrum of particle shapes and sizes was collected by the cyclone in contrast with those indicated in the bed material and filter catch. While relatively coarse (i.e., $>5 \mu \mathrm{m}$ ) particles appear in the filter catch, closer examination of these particles at smaller scales (higher magnifications) indicate them to be macroclusters of very fine $(<1 \mu \mathrm{m})$ particles. These clusters are artifacts of the deposition process on the filter, and/or of agglomeration that occurred during handling of the sample. 

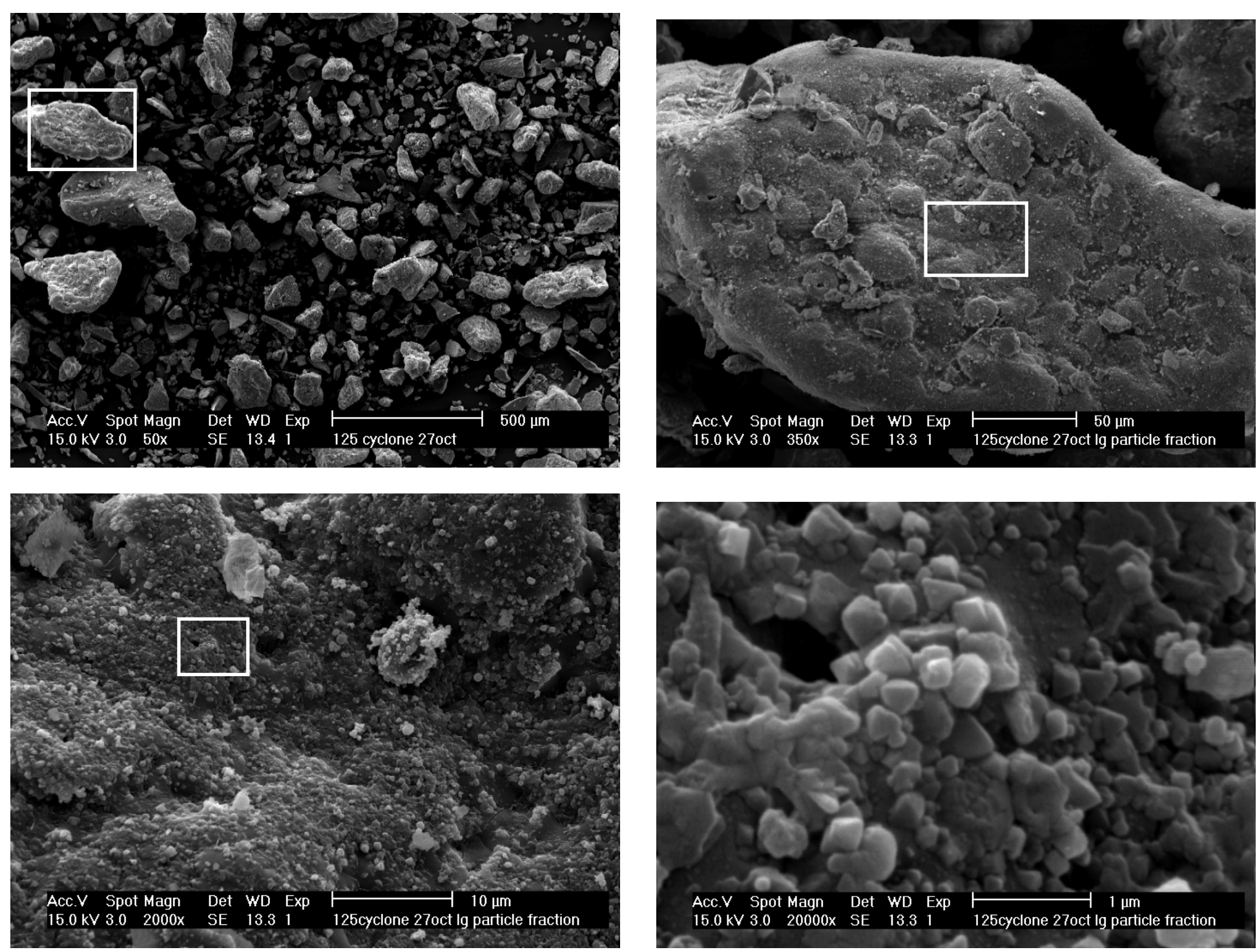

Figure 5.2-7. SEMs of cyclone material, sample 125 (Test Condition 5.3), from the TWR test series. Scale decreases from left to right and top to bottom. Insets show field illustrated at next lower scale to right or below. 

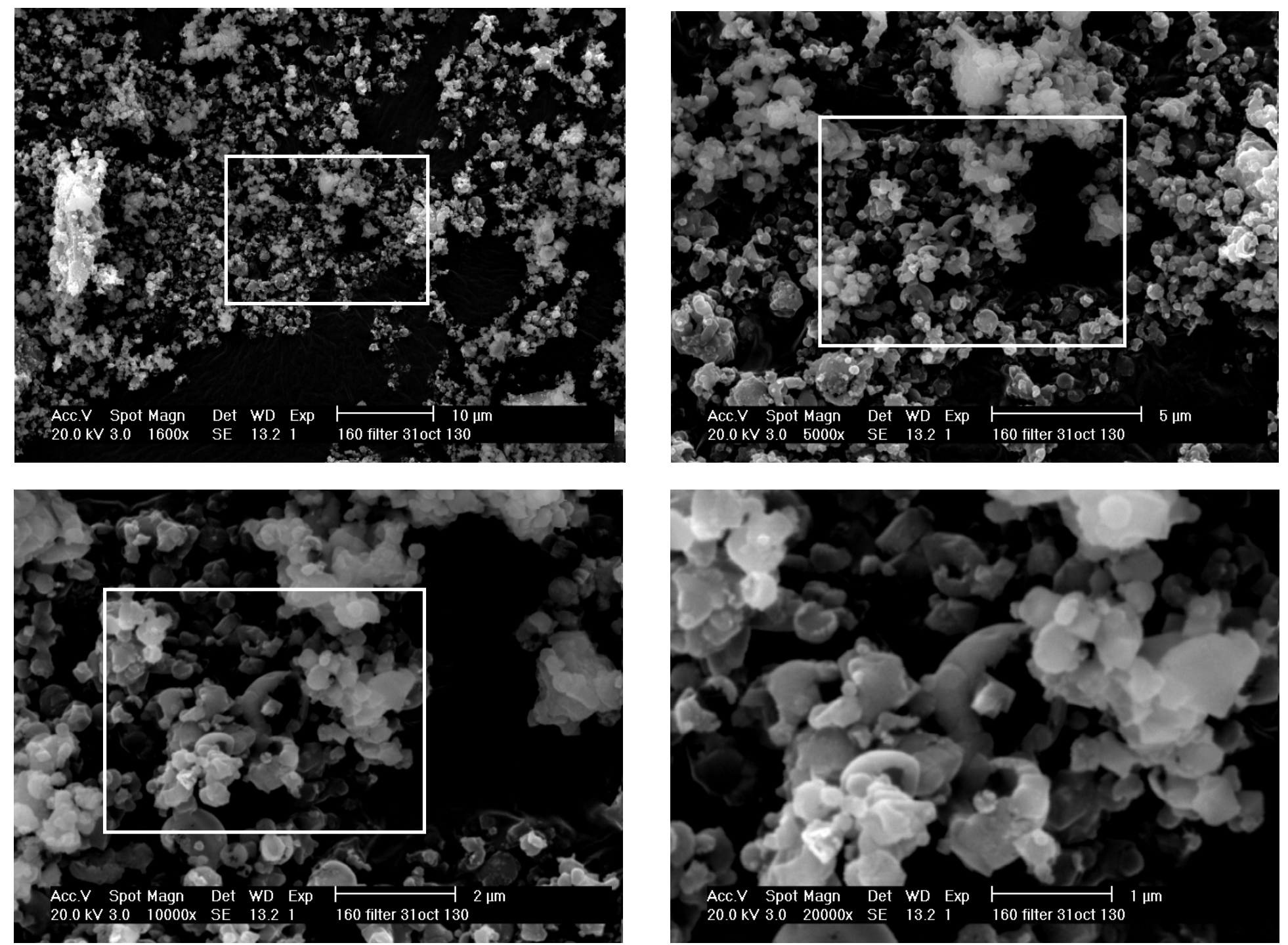

Figure 5.2-8. SEMs of filter material, sample 160 (Test Condition 5.4), from the TWR test series. Scale decreases from left to right and top to bottom. Insets show field illustrated at next lower scale to right or below. 
The same particle scales (less than a micron) are evident in the bed material and in the cyclone and filter catches, as shown by the views at 20,000x magnification. Similarities in the morphology and sizes of these submicron particles may indicate that all are formed by the same process. If the speculation above is correct about the genesis of the bed particles by metamorphosis of a surface layer of liquid feed, one might further speculate that the cyclone particles represent fragments of bed particles broken off by erosion (attrition) and collisions within the bed. The 20,000x view (lower right) in Figure 5.2-7 is consistent with the earlier speculation - that the submicron particles may be crystals formed from the feed liquids deposited on the surfaces of the largest bed particles, after evaporation of water and calcination. The SEMs seem to imply further that these submicron crystalline particles may either adhere to the unreacted, viscous liquid surface of the parent bed particle (as indicated at the 20,000x scale in Figure 5.2-7), or be released into the bulk gas phase as the surface evolves into an amorphous solid which "ripens" into yet more crystalline subparticles (lower left SEM in Figure 5.2-6).

Particle size distributions for the cyclone and filter catches were obtained using different techniques. For the cyclone catch, the sample was prepared by placing about 50-100 $\mathrm{mg}$ of material in a vial with $\sim 10 \mathrm{ml}$ of hexane. This suspension was dispersed using an immersed sonication probe for 2 minutes and was then added to a particle size analysis sample cell where it was further diluted with hexane until a target loading was achieved. The particles in the suspension were then counted using lowangle forward particle scattering to detect and size particles in the $0.1-700 \mu \mathrm{m}$ size range. The particle size distribution in a sample suspension was calculated using angular particle-scattering data collected with a He-Ne laser and a linear-detector array.

The results of these measurements are shown for two cyclone material samples in Figure 5.2-9. The figures suggest that samples 125 and 192 both display multi-modal size distributions. This is not unexpected, given the very heterogeneous mix of sizes seen in Figure 5.2-7. However, the two samples show the major peak in the PSD at particle sizes differing by nearly a factor of 10 (249 and $37 \mu \mathrm{m}$, respectively). If the two samples represent the same population, this result would indicate that one of the two PSDs is in error. The analyst who generated the light scattering measurements determined that occasionally the particle suspensions agglomerated and coalesced, probably due to static attraction, resulting in skewed distributions. This may explain the $249-\mu \mathrm{m}$ peak size for sample 125 . On the other hand, looking at the scale bar in the upper left SEM of Figure 5.2-7 it is obvious that particles of this size are very much in evidence. In the absence of additional size information, we therefore tentatively conclude that the cyclone PSD is fairly broad, with most of the mass concentrated between about 30 and $250 \mu \mathrm{m}$ in the cyclone material.

Particles in the filter catch were counted and sized using optical imaging software. This software scans the digitized optical microscope photographs and identifies particle profiles from variations in color, contrast, intensity, etc. These determinations are generally imprecise, except when all particles counted are physically separate in the optical image. Though this was not uniformly true in our case, some portions the optical microscope images approximated this criterion. The analyst was able to make use of this fact to obtain two approximate counts of particles in the size range 0.2-3.2 $\mu \mathrm{m}$ for one of the filter catch samples (Sample 193). From his counts, a volume-weighted PSD for the sample was obtained. The results are shown below in Figure 5.2-10 and suggest a bi-modal distribution with a small peak at about $0.5 \mu \mathrm{m}$, and a second, large peak at about $1.3-1.5 \mu \mathrm{m}$. These results are qualitatively consistent with the particle sizes evident in the lower right SEM in Figure 5.2-8. Note that the volume weighting of the PSDs in Figure 5.2-9 obscures the fact that the number of particles in the smaller mode $(0.5 \mu \mathrm{m})$ greatly exceeds that in the larger size classes. This underscores the need to design the filter to control the particles in the lower size class. 


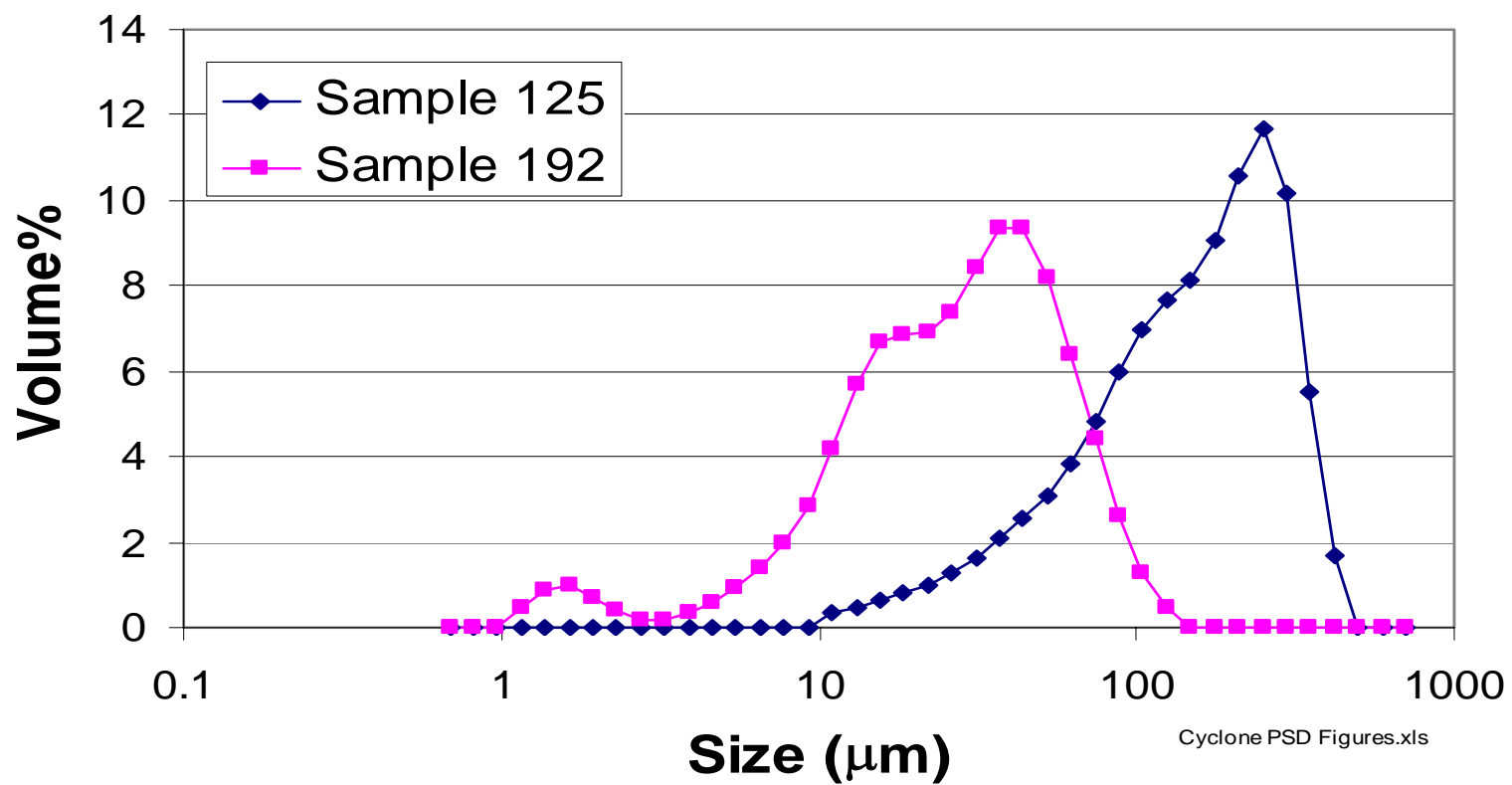

Figure 5.2-9. TWR flow sheet PSD for cyclone catch.

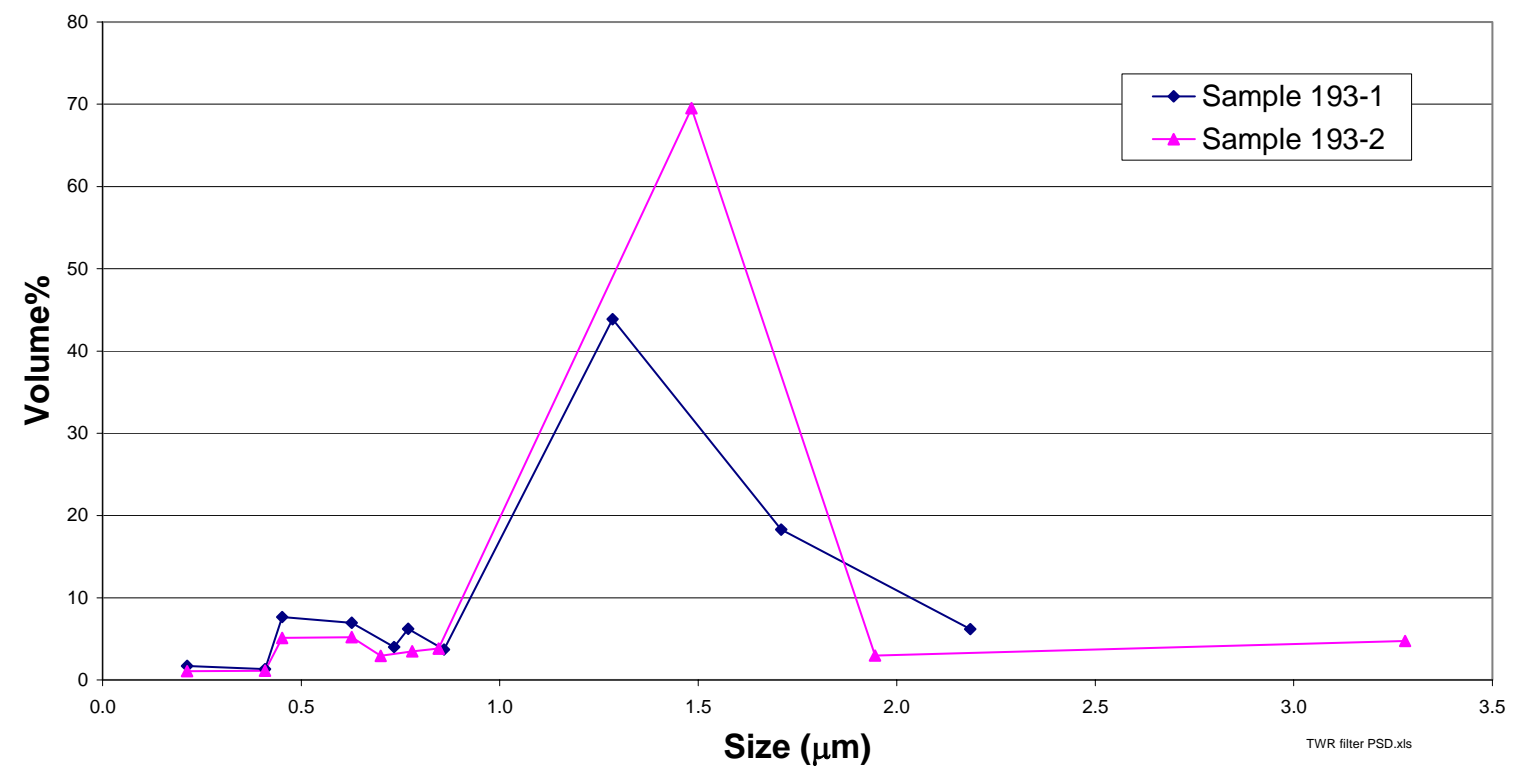

Figure 5.2-10. TWR flow sheet PSD for filter catch. 
Filter material particle and bulk densities were not measured for the TWR tests. However, a single measurement of these parameters for the cyclone material yielded the following information:

$$
\begin{aligned}
& \text { Cyclone material particle density }=\quad 2.71 \mathrm{gm} / \mathrm{cm}^{3} \\
& \text { Cyclone material bulk density }=\quad 1.01 \mathrm{gm} / \mathrm{cm}^{3} .
\end{aligned}
$$

These densities of the cyclone material are lower by $\sim 5 \%$ and $\sim 26 \%$ than the respective lowest measured densities of the bed product.

\subsection{Process Effluent Compositions}

The solid and gaseous effluent compositions were determined at each effluent location. Samples of bed product, cyclone catch, and filter catch collected both during test operations and at the end of the test series, were analyzed for the main constituents of the feedstreams. The off-gas was characterized at two locations: at the outlet of the heated filter (upstream of the thermal oxidizer) and downstream of the oxidizer, wet scrubber, and reheater.

\subsubsection{Solid Product Compositions}

The composition of the solid products was estimated based on the SBW simulant feedrate and composition, and also measured using sample collection and analysis.

The product composition calculated from the SBW simulant composition is estimated in Table 5.3-1. This calculation excludes any residual alumina bed media. The table also shows the solid product rate per liter of SBW simulant and the rate of carbon used to form the carbonate product from the input feed solids. The product composition was estimated using simplifying assumptions based in part on chemical equilibrium composition calculations under representative steam reformer conditions using a commercial chemical equilibrium model (HSC Chemistry). The calculations included the major chemical species in the feed and those expected to be formed in the products (Taylor 2004). The equilibrium modeling did not account for some of the minor constituents, including $\mathrm{Cu}, \mathrm{Fe}, \mathrm{Ni}$, and $\mathrm{Pb}$, and some of the potential chloride, fluoride, phosphate, and sulfate species. Simplifying assumptions are listed in the table.

The bed product, cyclone catch, and filter catch sample analyses are shown in Tables 5.3-2 and 5.3-3. The concentrations of primary simulant feed products $\left(\mathrm{CO}_{3}, \mathrm{~K}\right.$, and $\left.\mathrm{Na}\right)$ in the bed samples show an increasing trend with time in the run. To the extent that the equilibrium calculations represent the actual steam reforming process, the amounts of the above species in the bed product would continue to asymptotically approach their theoretically calculated concentrations (up to $29 \mathrm{wt} \% \mathrm{CO}_{3}, 5.2 \mathrm{wt} \% \mathrm{~K}$, and $30 \mathrm{wt} \% \mathrm{Na}$ ). The degree to which the elemental feed constituents approached their theoretical weight fractions in the bed, cyclone, and filter products is indicated in the last row of Table 5.3-2 and the last two rows of Table 5.3-3. For $\mathrm{CO}_{3}, \mathrm{~K}$, and $\mathrm{Na}$, the measured weight fractions ranged from 53 to $92 \%$ of the theoretical values. These data indicate that most of the bed product was solids from the simulant feed rather than starting bed.

\subsubsection{Scrub Solution and CEMS Condensate Compositions}

Samples of the scrub solution were collected and analyzed to indicate amounts of various species that were volatilized or elutriated out of the fluidized bed and also passed through the cyclone and heated filter to be captured in the wet scrubber. The scrub solution and CEMS condensate sample analyses are shown in Table 5.3-4. 
The scrubber was designed with heat exchanger cooling to remove latent heat from the off-gas as the scrubber cools the hot off-gas to its dewpoint and removes acid gas and particulate matter. By extracting latent heat from the off-gas, the scrubber can be operated water neutral (essentially no scrub water is evaporated and no moisture in the off-gas is condensed). The heat removal from the scrub solution is automatically controlled to maintain a relatively constant scrub water level in the scrub tank.

Table 5.3-1. Calculated solid product distribution and composition based on chemical equilibrium calculations.

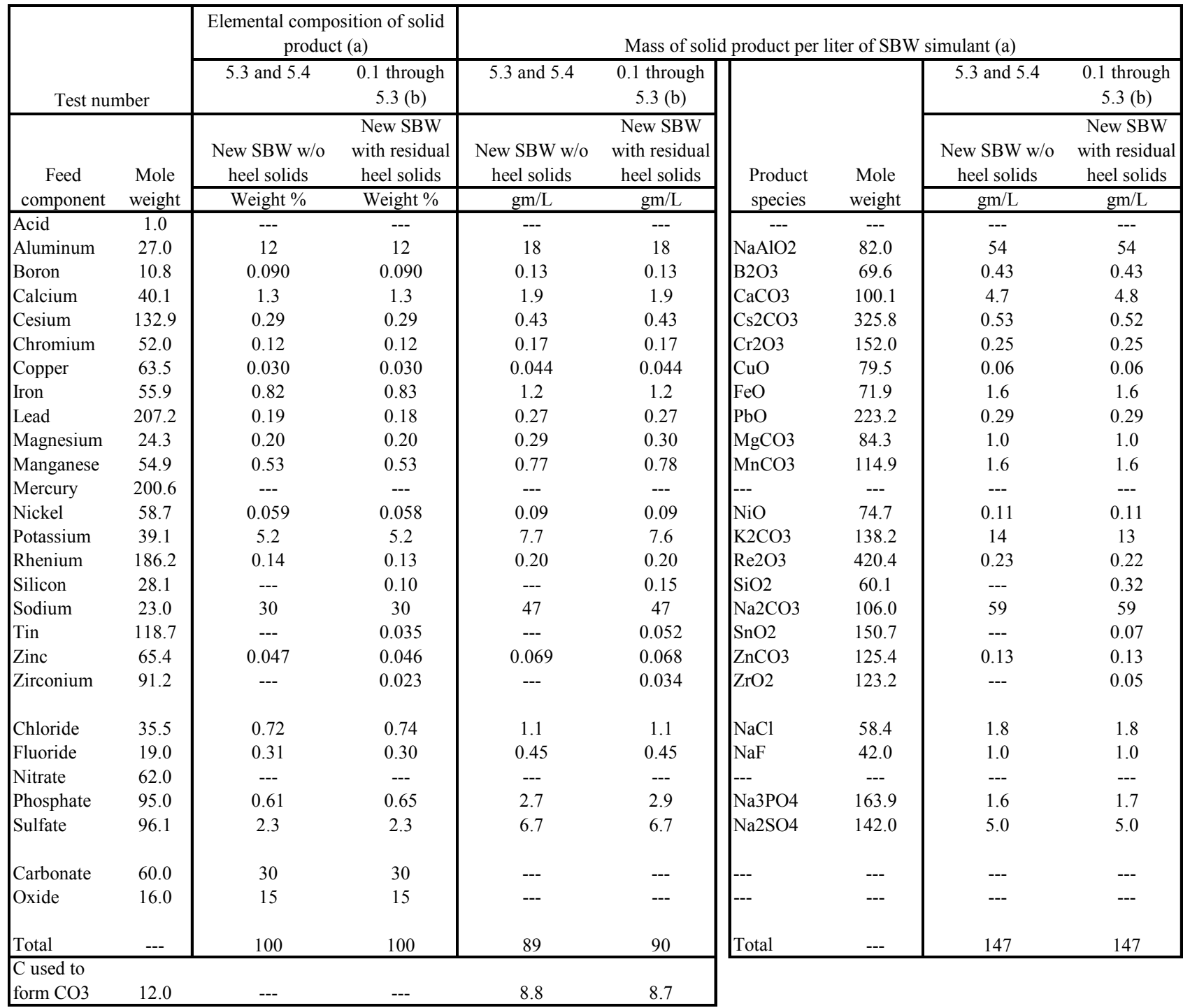

a. Not including any starting bed material or organic carbon, and assuming no volatilization except for water, acid, and nitrate.

b. Condition 5.3 included feed w/ and w/o solids. However, mass balances assume 5.3 was entirely w/ solids. 
Table 5.3-2. Elemental composition of the bed product for the TWR test series.

\begin{tabular}{|c|c|c|c|c|c|c|c|c|c|c|c|c|c|c|c|c|c|c|c|c|c|c|c|c|c|c|}
\hline \multirow[b]{2}{*}{ Sample } & \multirow[b]{2}{*}{ Sample date } & \multirow{2}{*}{$\begin{array}{l}\text { Test } \\
\text { Cond }\end{array}$} & \multicolumn{24}{|c|}{ Measured concentrations, wt $\%$} \\
\hline & & & TOC & $\mathrm{CO}_{3}$ & $\mathrm{NO}_{3}$ & $\mathrm{SO}_{4}$ & $\mathrm{Cl}$ & $\mathrm{F}$ & $\mathrm{Al}$ & $\mathrm{Ca}$ & $\mathrm{Cr}$ & Cs & $\mathrm{Cu}$ & $\mathrm{Fe}$ & $\mathrm{Hg}$ & $\mathrm{K}$ & $\mathrm{Mg}$ & $\mathrm{Mn}$ & $\mathrm{Na}$ & $\mathrm{Ni}$ & $\mathrm{Pb}$ & $\operatorname{Re}$ & $\mathrm{Si}$ & Sn & $\mathrm{Zn}$ & $\mathrm{Zr}$ \\
\hline 140 & $10 / 29 / 20035: 50$ & 5.3 & 0.008 & 13.13 & 0.354 & 1.415 & 0.223 & 0.061 & 3.6 & 0.255 & 0.035 & 0.045 & 0.006 & 0.193 & --- & 1.536 & 0.061 & 0.166 & 11.57 & 0.019 & 0.028 & 0.007 & 0.027 & 0.000 & 0.015 & 0.003 \\
\hline 153 & 10/30/2003 9:00 & 5.4 & 0.054 & 15.97 & --- & --- & --- & --- & 4.7 & 0.385 & 0.047 & 0.053 & 0.004 & 0.279 & --- & 2.033 & 0.10 & 0.183 & 14.68 & 0.025 & 0.038 & $0.007^{L}$ & 0.019 & 0.000 & 0.019 & 0.004 \\
\hline 179 & $10 / 31 / 200313: 00$ & 5.4 & 0.054 & 15.97 & --- & --- & --- & --- & 6.4 & 0.59 & 0.075 & 0.061 & 0.001 & 0.474 & --- & 0.314 & 0.166 & 0.215 & 20.48 & 0.039 & 0.034 & 0.006 & 0.024 & 0.000 & 0.030 & 0.002 \\
\hline 183 & 10/31/2003 17:00 & 5.4 & 0.054 & 15.97 & --- & --- & --- & --- & 6.4 & 0.615 & 0.071 & 0.062 & 0.001 & 0.471 & --- & 3.463[ & 0.173 & 0.21[ & 20.76 & 0.038[ & 0.042 & 0.014 & 0.017 & 0.000 & 0.030 & 0.003 \\
\hline 197 & 11/3/2003 9:57 & 5.4 & 0.1 & 18.81 & 0.003 & 2.994 & 0.334 & 0.001 & 5.7 & 0.645 & 0.080 & 0.065 & 0.000 & 0.52 & --- & 3.703 & 0.164 & 0.218 & 20.25 & 0.04 & 0.035 & 0.028 & 0.016 & 0.000 & 0.034 & 0.002 \\
\hline \multicolumn{4}{|c|}{ Calculated product composition, $\mathrm{wt} \%$} & 29.66 & --- & 2.28 & 0.737 & 0.305 & 12.13 & 1.291 & 0.12 & 0.29 & 0.03 & 0.83 & 0.000 & 5.166 & 0.20 & 0.529 & 30.05 & 0.058 & 0.184 & 0.135 & 0.095 & 0.033 & 0.046 & 0.022 \\
\hline \multicolumn{4}{|c|}{$\begin{array}{l}\text { Highest measured concentration as a percent of the } \\
\text { calculated product composition }\end{array}$} & 63.41 & -- & 131.3 & 45.32 & 20 & 52.81 & 49.96 & 67.76 & 22.39 & 21.59 & 62.64 & --- & 71.69 & 85.41 & 41.18 & 69.08 & 68.09 & 22.78 & 20.83 & 28.21 & 1.493 & 73.19 & 16.34 \\
\hline
\end{tabular}
Note 1: The feed constituents gradually increase in the bed product as the mass of starting bed in the fluidized bed is replaced by solid feed products.

Table 5.3-3. Elemental composition of the cyclone and filter catch samples for the TWR test series.

\begin{tabular}{|c|c|c|c|c|c|c|c|c|c|c|c|c|c|c|c|c|c|c|c|c|c|c|c|c|c|c|}
\hline \multirow[b]{2}{*}{ Sample } & \multirow[b]{2}{*}{ Sample date } & \multirow{2}{*}{$\begin{array}{l}\text { Test } \\
\text { Cond }\end{array}$} & \multicolumn{24}{|c|}{ Measured concentrations, $\mathrm{wt} \%$} \\
\hline & & & TOC & $\mathrm{CO}_{3}$ & $\mathrm{NO}_{3}$ & $\mathrm{SO}_{4}$ & $\mathrm{Cl}$ & $\mathrm{F}$ & $\mathrm{Al}$ & $\mathrm{Ca}$ & $\mathrm{Cr}$ & Cs & $\mathrm{Cu}$ & $\mathrm{Fe}$ & $\mathrm{Hg}$ & $\mathrm{K}$ & $\mathrm{Mg}$ & $\mathrm{Mn}$ & $\mathrm{Na}$ & $\mathrm{Ni}$ & $\mathrm{Pb}$ & $\mathrm{Re}$ & $\mathrm{Si}$ & Sn & $\mathrm{Zn}$ & $\mathrm{Zr}$ \\
\hline \multicolumn{27}{|c|}{ Cyclone samples } \\
\hline 125 & 10/27/2003 21:00 & 5.3 & 0.6 & 6.939 & 0.177 & 0.744 & 0.155 & 0.076 & 3.373 & 0.069 & 0.025 & 0.095 & 0.007 & 0.136 & --- & 0.992 & 0.029 & 0.101 & 6.076 & 0.025 & 0.064 & 0.084 & 0.208 & 0.016 & 0.014 & 0.021 \\
\hline 142 & 10/29/2003 9:00 & 5.3 & 1.9 & 22.78 & 0.878 & 3.508 & 0.939 & 0.16 & 5.908 & 0.517 & 0.076 & 0.31 & 0.013 & 0.512 & --- & 3.856 & 0.123 & 0.381 & 21.13 & 0.053 & 0.158 & 0.12 & 0.10 & 0.000 & 0.036 & 0.012 \\
\hline 150 & 10/30/2003 9:00 & 5.4 & --- & -- & --- & --- & --- & --- & 4.611 & 0.364 & 0.066 & 0.356 & 0.011 & 0.46 & --- & 3.619 & 0.081 & 0.352 & 18.3 & 0.055 & 0.133 & 0.161 & 0.082 & 0.000 & 0.031 & 0.007 \\
\hline 192 & 10/31/2003 21:00 & 5.4 & 2.1 & 19.59 & 0.03 & 3.389 & 1.24 & 0.08 & 3.337 & 0.28 & 0.092 & 0.289 & 0.005 & 0.652 & --- & 2.839 & 0.111 & 0.336 & 11.99 & 0.068 & 0.207 & 0.149 & 0.131 & 0.000 & 0.041 & 0.008 \\
\hline \multicolumn{3}{|c|}{ Cyclone averages } & 1.5 & 16.44 & 0.362 & 2.547 & 0.778 & 0.105 & 4.307 & 0.308 & 0.065 & 0.263 & 0.009 & 0.44 & --- & 2.827 & 0.086 & 0.292 & 14.38 & 0.05 & 0.141 & 0.128 & 0.129 & 0.004 & 0.031 & 0.012 \\
\hline \multicolumn{27}{|c|}{ Filter samples } \\
\hline 124 & 10/27/2003 21:00 & 5.3 & 4.1 & 13.53 & 0.604 & 4.896 & 3.281 & 1.018 & 7.529 & 0.81 & 0.129 & 2 & 0.049 & 0.679 & --- & 5.388 & 0.177 & 0.631 & 14.13 & 0.063 & 0.116 & 0.696 & 0.067 & 0.004 & 0.06 & 0.008 \\
\hline 143 & 10/29/2003 9:30 & 5.3 & 6.5 & 15.71 & 0.566 & 3.907 & 2.22 & 1.23 & 6.365 & 0.7 & 0.105 & 1.855 & 0.009 & 0.641 & --- & 5.524 & 0.088 & 0.507 & 14.91 & 0.061 & 0.306 & 0.432 & 0.136 & 0.000 & 0.039 & 0.012 \\
\hline 152 & 10/30/2003 9:00 & 5.4 & 6.35 & 17.23 & & & & & 5.027 & 0.376 & 0.076 & 0.821 & 0.013 & 0.427 & --- & 3.317 & 0.094 & 0.279 & 14.34 & 0.066 & 0.201 & 0.426 & 0.134 & 0.000 & 0.03 & 0.007 \\
\hline 193 & 10/31/2003 21:00 & 5.4 & 6.2 & 18.75 & 0.056 & 5.256 & 6.639 & 0.41 & 7.819 & 0.799 & 0.149 & 1.426 & 0.004 & 0.931 & --- & 6.79 & 0.242 & 0.376 & 12.14 & 0.067 & 0.303 & 0.522 & 0.071 & 0.000 & 0.062 & 0.003 \\
\hline \multicolumn{3}{|c|}{ Filter averages } & & 15.49 & 0.585 & 4.401 & 2.751 & 1.124 & 6.307 & 0.629 & 0.103 & 1.559 & 0.024 & 0.582 & --- & 4.743 & 0.12 & 0.472 & 14.46 & 0.064 & 0.208 & 0.518 & 0.112 & 0.002 & 0.043 & 0.009 \\
\hline \multicolumn{4}{|c|}{ Calculated product composition, $\mathrm{wt} \%$} & 29.66 & --- & 2.28 & 0.737 & 0.305 & 12.13 & 1.291 & 0.117 & 0.29 & 0.03 & 0.83 & 0 & 5.166 & 0.203 & 0.529 & 30.05 & 0.058 & 0.184 & 0.135 & 0.095 & 0.033 & 0.046 & 0.022 \\
\hline \multicolumn{4}{|c|}{$\begin{array}{l}\text { Average cyclone concentration as a percent of the } \\
\text { calculated product composition }\end{array}$} & 55.41 & --- & 111.7 & 105.5 & 34.51 & 35.51 & 23.82 & 55.29 & 90.5 & 30.23 & 53.02 & --- & 54.71 & 42.49 & 55.34 & 47.83 & 86.11 & 76.23 & 95.17 & 136.4 & 12.45 & 66.22 & 54.48 \\
\hline \multicolumn{4}{|c|}{$\begin{array}{l}\text { Average filter concentration as a percent of the } \\
\text { calculated product composition }\end{array}$} & 52.23 & --- & 193 & 373.3 & 368.6 & 52 & 48.69 & 88.06 & 536.9 & 79.35 & 70.16 & 0 & 91.81 & 59.06 & 89.35 & 48.1 & 109.2 & 112.5 & 383.8 & 118.7 & --- & 92.67 & -- \\
\hline
\end{tabular}


Table 5.3-4. Scrub solution and CEMS condensate composition for the TWR test series.

\begin{tabular}{|c|c|c|c|c|c|c|c|c|c|c|c|c|c|c|c|c|c|c|c|c|c|c|c|c|c|c|c|}
\hline \multirow[b]{2}{*}{ Sample } & \multirow[b]{2}{*}{ Sample date } & \multirow{2}{*}{$\begin{array}{l}\text { Test } \\
\text { Cond }\end{array}$} & \multicolumn{25}{|c|}{ Measured concentrations } \\
\hline & & & TOC & Carbon & $\mathrm{CO}_{3}$ & $\mathrm{NO}_{3}$ & $\mathrm{SO}_{4}$ & $\mathrm{Cl}$ & $\mathrm{F}$ & $\mathrm{Al}$ & $\mathrm{Ca}$ & $\mathrm{Cr}$ & Cs & $\mathrm{Cu}$ & $\mathrm{Fe}$ & $\mathrm{Hg}$ & $\mathrm{K}$ & $\mathrm{Mg}$ & $\mathrm{Mn}$ & $\mathrm{Na}$ & $\mathrm{Ni}$ & $\mathrm{Pb}$ & $\operatorname{Re}$ & $\mathrm{Si}$ & Sn & $\mathrm{Zn}$ & $\mathrm{Zr}$ \\
\hline \multicolumn{3}{|c|}{ Scrub solution } & $\mathrm{ug} / \mathrm{ml}$ & $\mathrm{ug} / \mathrm{ml}$ & --- & $\mathrm{ug} / \mathrm{ml}$ & $\mathrm{ug} / \mathrm{ml}$ & $\mathrm{ug} / \mathrm{ml}$ & $\mathrm{ug} / \mathrm{ml}$ & $\mathrm{ug} / \mathrm{ml}$ & $\mathrm{ug} / \mathrm{ml}$ & $\mathrm{ug} / \mathrm{ml}$ & $\mathrm{ug} / \mathrm{ml}$ & $\mathrm{ug} / \mathrm{ml}$ & $\mathrm{ug} / \mathrm{ml}$ & $\mathrm{ug} / \mathrm{ml}$ & $\mathrm{ug} / \mathrm{ml}$ & $\mathrm{ug} / \mathrm{ml}$ & $\mathrm{ug} / \mathrm{ml}$ & $\mathrm{ug} / \mathrm{ml}$ & $\mathrm{ug} / \mathrm{ml}$ & $\mathrm{ug} / \mathrm{ml}$ & $\mathrm{ug} / \mathrm{ml}$ & $\mathrm{ug} / \mathrm{ml}$ & $\mathrm{ug} / \mathrm{ml}$ & $\mathrm{ug} / \mathrm{ml}$ & $\mathrm{ug} / \mathrm{ml}$ \\
\hline 107 & 10/24/2003 14:30 & 1.4 & 9.4 & 13.2 & --- & 12 & 29 & 18 & 22 & 7.6 & 10 & 0.089 & 0.428 & 0.084 & 0.14 & 0.01 & 2.195 & 1.135 & 0.04 & 10.04 & 0.32 & 0.055 & 0.044 & 17.34 & 0.134 & 0.375 & 0.06 \\
\hline 123 & 10/27/2003 21:00 & 5.3 & 4.9 & 9.0 & --- & 2.0 & 5.4 & 4.0 & 6.8 & --- & --- & --- & --- & --- & --- & 0.01 & --- & -- & --- & --- & -- & -- & --- & -- & --- & -- & --- \\
\hline 141 & 10/29/2003 9:00 & 5.3 & 5.1 & 8.4 & --- & 5.0 & 15 & 6.0 & 11 & --- & --- & --- & --- & --- & --- & 0.01 & --- & --- & --- & --- & --- & --- & --- & --- & --- & --- & --- \\
\hline 149 & 10/30/2003 9:00 & 5.4 & 4.1 & 6.5 & --- & 6.1 & 17 & 6.7 & 13 & --- & --- & --- & --- & --- & --- & 0.019 & --- & --- & --- & --- & -- & --- & --- & --- & --- & --- & --- \\
\hline 186 & 10/31/2003 17:00 & 5.4 & 3.7 & 7.8 & --- & 8.3 & 24 & 8.6 & 15 & --- & --- & --- & -- & -- & -- & 0.012 & -- & -- & -- & -- & -- & -- & -- & -- & -- & -- & -- \\
\hline 194 & 10/31/2003 21:00 & 5.4 & 3.9 & 7.5 & --- & 8.3 & 24 & 8.6 & 16 & 5.4 & 4.9 & 0.089 & 0.299 & 0.11 & 0.7 & 0.013 & 2.0 & 0.23 & 0.04 & 0.425 & 0.44 & 0.05 & 0.225 & 2.495 & 0.134 & 1.64 & 0.565 \\
\hline \multicolumn{3}{|c|}{ CEMS 1 condensate } & $\mathrm{wt} \%$ & --- & $\mathrm{M}$ & $\mathrm{ug} / \mathrm{ml}$ & $\mathrm{ug} / \mathrm{ml}$ & $\mathrm{ug} / \mathrm{ml}$ & $\mathrm{ug} / \mathrm{ml}$ & & & & & & & & & & & & \multirow{3}{*}{\multicolumn{7}{|c|}{ [Master Analytical Data (ddt).xls]Master RFA (2) }} \\
\hline 166 & 10/31/2003 5:20 & 5.4 & 5.8 & -- & 0.22 & 2.8 & 2.9 & 0.8 & 48 & & & & & & & & & & & & & & & & & & \\
\hline 195 & 10/31/2003 21:00 & 5.4 & 5.8 & -- & 0.20 & 2.8 & 2.9 & 0.8 & 52 & & & & & & & & & & & & & & & & & & \\
\hline
\end{tabular}

Note: The first entry in on 10/24/03 represents the end-of-run scrub solution from the first week of testing. The scrub liquor was subsequently replaced with fresh water before the start of the second week testing. The monotonic increase in concentrations of the above species is indicated by the table entries starting with the second. 
As the scrub solution volume remains constant at about 45 gallons, species scrubbed out of the offgas become enriched in the scrub solution. The scrub solution was not changed during the test series, so the ending composition of the scrub solution provides the total amounts of species scrubbed during the test series. The concentrations of key species, including $\mathrm{NO}_{3}, \mathrm{SO}_{4}, \mathrm{Cl}, \mathrm{F}$, and $\mathrm{Hg}$ all increased to a maximum at the end of the test series. In order to avoid complications that would be caused by adding a $\mathrm{pH}$-neutralizing caustic, none was added. The scrub solution became slightly acidic during the test series. The $\mathrm{pH}$ varied between 4.7 and 5.7 during the first test week, and between 3.9 and 4.9 during the second.

CEMS 1 measures the off-gas composition at the outlet of the heated filter and upstream of the thermal oxidizer. The off-gas at this location contains various incompletely oxidized gas species, including $\mathrm{CO}, \mathrm{CH}_{4}$, and other hydrocarbons not speciated during this test but measured as total hydrocarbons (THC). The water condensate collected in the CEMS 1 condenser contains levels of watersoluble or condensable hydrocarbons, as well as other water-soluble or condensable species including $\mathrm{NH}_{3}, \mathrm{HCN}, \mathrm{HCl}, \mathrm{HF}, \mathrm{SO}_{2}, \mathrm{H}_{3} \mathrm{PO}_{4}$, and $\mathrm{NO}_{2}$. The CEMS 1 condensate analysis indicates the presence of species in the off-gas that were not directly measured by CEMS 1, including $\mathrm{CO}_{3}, \mathrm{NO}_{3}, \mathrm{SO}_{4}, \mathrm{Cl}$, and $\mathrm{F}$.

The CEMS 1 condensate analysis also indicates the amount of $\mathrm{NO}_{2}$ scrubbed in the condenser and thereby not detected by the CEMS $1 \mathrm{NO}_{\mathrm{x}}$ analyzer. The nitrate in the condensate represents less than $0.02 \%$ of the average amount of $\mathrm{NO}$ detected by the $\mathrm{NO}_{\mathrm{x}}$ analyzer, indicating that although some $\mathrm{NO}_{\mathrm{x}}$ was scrubbed in the CEMS 1 condensate, that amount was negligible compared to the amount of NO detected in the off-gas.

The CEMS 2 condensate could contain species that remain in the off-gas downstream of the thermal oxidizer and the wet scrubber. Levels of $\mathrm{SO}_{4}, \mathrm{Cl}$, and $\mathrm{F}$ were less than the levels of those species found in the CEMS 1 condensate.

\subsubsection{Off-gas Composition}

The CEMS 1 was used to measure the off-gas composition at the outlet of the heated filter (upstream of the thermal oxidizer) and downstream of the oxidizer. The CEMS 2 was used to measure the off-gas composition at operator-selectable locations at the inlet of the carbon bed or the outlet of any of the three stages of the carbon bed.

5.3.3.1 Off-gas Composition at the Steam Reformer Heated Filter Outlet. The average off-gas composition (wet basis) at the outlet of the heated filter is shown in Table 5.3-5 for each test condition. The wet basis composition was calculated from the dry, as-measured composition by (a) correcting for zero and span calibration error/drift, and (b) normalizing the dry composition to a wet basis using the off-gas moisture content. The moisture content at the filter outlet location was calculated from the fluidized-bed input flow rates of fluidizing steam, evaporated water from the SBW and reductant feeds, and water of oxidation of the reductant feed. The moisture content calculations are shown in water mass balance calculations.

The off-gas measurements were continuous and were recorded electronically several times per minute. Ten-minute averages are shown in Figure 5.3-1 and 5.3-2. The trends over time indicate graphically how the gas composition varied during the test series.

All valid 10-minute data were averaged over the duration of each test condition to yield the timeweighted average of the test condition averages. The CEMS data were corrected for zero calibration error, zero drift, span calibration error, span drift, and interferences if the errors, drifts, and interferences were outside of acceptance limits. The calibration data are summarized in Appendix b. 
Table 5.3-5. Off-gas composition (wet basis) at the outlet of the heated filter for the TWR test series.

\begin{tabular}{|c|c|c|c|c|c|c|c|c|c|c|}
\hline \multirow[b]{2}{*}{$\begin{array}{l}\text { First week test } \\
\text { condition }\end{array}$} & \multicolumn{9}{|c|}{ Average off-gas composition for each test on a wet basis } & \multirow[b]{2}{*}{$\begin{array}{c}\text { Off-gas } \\
\text { MW }\end{array}$} \\
\hline & $\mathrm{O}_{2}, \%$ & $\begin{array}{c}\mathrm{CO}_{2}, \\
\%\end{array}$ & $\mathrm{CO}, \%$ & $\begin{array}{l}\mathrm{NO}, \\
\mathrm{ppm}\end{array}$ & $\mathrm{H}_{2}, \%$ & $\begin{array}{l}\mathrm{CH}_{4} \\
\mathrm{ppm}\end{array}$ & $\begin{array}{c}\mathrm{H}_{2} \mathrm{O}, \\
\%\end{array}$ & $\mathrm{~N}_{2}, \%$ & $\begin{array}{c}\text { Total, } \\
\%\end{array}$ & \\
\hline 1.0 & 0.1 & 66.2 & 2.25 & 639 & 2.9 & 8,611 & 29.4 & -0.8 & 100.0 & 34.9 \\
\hline 1.1 & 0.1 & 68.7 & 1.33 & 1,769 & 1.8 & 7,457 & 29.1 & -1.0 & 100.0 & 35.6 \\
\hline 2.1 & 0.1 & 69.2 & 0.85 & 1,393 & 1.4 & 13,450 & 29.1 & -0.7 & 100.0 & 35.8 \\
\hline 2.2 & 0.1 & 66.7 & 0.67 & 975 & 1.5 & 17,909 & 29.4 & 1.7 & 100.0 & 35.3 \\
\hline 3.1 & 0.2 & 63.9 & 0.59 & 1,945 & 2.3 & 8,808 & 29.4 & 3.7 & 100.0 & 34.7 \\
\hline 3.2 & 0.2 & 64.5 & 0.54 & 2,319 & 2.1 & 7,138 & 30.0 & 2.7 & 100.0 & 34.8 \\
\hline 3.3 & 0.0 & 62.8 & 0.63 & 1,023 & 2.7 & 33,349 & 29.5 & 4.4 & 100.0 & 34.4 \\
\hline 3.4 & 0.0 & 63.2 & 0.59 & --- & 2.5 & 16,965 & 29.2 & 4.5 & 100.0 & 34.5 \\
\hline 3.5 & -0.02 & 64.0 & 0.52 & 339 & 2.1 & 12,010 & 29.3 & 4.1 & 100.0 & 34.7 \\
\hline 3.6 & -0.01 & 64.4 & 0.50 & 339 & 2.0 & --- & 29.2 & 3.8 & 100.0 & 34.9 \\
\hline Shutdown & & & & & & & & & & \\
\hline 1.2 & 0.1 & 66.0 & 0.31 & 1,544 & 2.6 & 6,761 & 33.9 & -2.9 & 100.0 & 34.5 \\
\hline 1.3 & 0.1 & 51.2 & 0.29 & 1,693 & 1.1 & 7,728 & 36.6 & 10.6 & 100.0 & 32.2 \\
\hline 3.7 & 0.1 & 62.6 & 0.31 & 1,665 & 1.2 & --- & 36.0 & -0.2 & 100.0 & 34.1 \\
\hline Overall average & 0.1 & 61.8 & 0.48 & 1,603 & 1.9 & 10,788 & 33.0 & 2.8 & 100.0 & 34.1 \\
\hline Std Dev & 0.1 & 8.3 & 0.33 & 468 & 0.7 & 6,574 & 3.1 & 7.4 & 0.0 & 1.4 \\
\hline
\end{tabular}

TWR FY04 Week 1 CEMS-MB

\begin{tabular}{|c|c|c|c|c|c|c|c|c|c|c|}
\hline \multirow[b]{2}{*}{$\begin{array}{c}\text { Second week test } \\
\text { condition }\end{array}$} & \multicolumn{9}{|c|}{ Average off-gas composition for each test on a wet basis } & \multirow[b]{2}{*}{$\begin{array}{l}\text { Off-gas } \\
\text { MW }\end{array}$} \\
\hline & $\mathrm{O}_{2}, \%$ & $\begin{array}{c}\mathrm{CO}_{2}, \\
\%\end{array}$ & $\mathrm{CO}, \%$ & $\begin{array}{l}\text { NO, } \\
\text { ppm }\end{array}$ & $\begin{array}{l}\mathrm{H}_{2}, \\
\%\end{array}$ & $\begin{array}{l}\mathrm{CH}_{4}, \\
\mathrm{ppm}\end{array}$ & $\mathrm{H}_{2} \mathrm{O}, \%$ & $\mathrm{~N}_{2}, \%$ & $\begin{array}{c}\text { Total, } \\
\%\end{array}$ & \\
\hline 5.1 & 0.27 & 56.7 & 0.34 & 3,249 & 1.0 & 5,795 & 41.5 & 0.3 & 100.0 & 32.8 \\
\hline 5.2 & 0.3 & 53.7 & 0.36 & 2,400 & 1.2 & 5,941 & 42.7 & 2.2 & 100.0 & 32.1 \\
\hline 5.3 & 0.2 & 56.9 & 0.37 & 2,029 & 1.5 & 5,904 & 43.0 & -1.9 & 100.0 & 32.4 \\
\hline Shutdown & & & & & & & & & & \\
\hline 5.3 & 0.1 & 55.6 & 0.35 & 1,574 & 2.5 & 6,005 & 41.9 & -0.5 & 100.0 & 32.1 \\
\hline Nozzle Plug & & & & & & & & & & \\
\hline 5.3 & 0.1 & 56.4 & 0.36 & 1,150 & 2.2 & 5,976 & 41.5 & -0.5 & 100.0 & 32.3 \\
\hline Nozzle Plug & & & & & & & & & & \\
\hline 5.3 & 0.1 & 50.0 & 0.33 & 1,678 & 2.4 & 5,879 & 43.0 & 4.6 & 100.0 & 31.5 \\
\hline 5.3 average & 0.1 & 49.6 & 0.33 & 1,670 & 2.4 & 5,864 & 43.1 & 4.9 & 100.0 & 31.4 \\
\hline 5.4 & 0.2 & 51.8 & 0.30 & 1,802 & 2.4 & 5,757 & 44.2 & 1.1 & 100.0 & 31.3 \\
\hline Nozzle Plug & & & & & & & & & & \\
\hline 5.4 & 0.2 & 51.9 & 0.30 & 1,786 & 2.5 & 5,751 & 44.2 & 1.0 & 100.0 & 31.2 \\
\hline Nozzle Plug & & & & & & & & & & \\
\hline 5.4 & 0.3 & 53.3 & 0.32 & 3,073 & 2.5 & 5,871 & 43.3 & 0.2 & 100.0 & 31.5 \\
\hline 5.4 average & 0.3 & 53.1 & 0.32 & 2,650 & 2.5 & 5,859 & 43.4 & 0.3 & 100.0 & 31.5 \\
\hline Overall average & 0.2 & 54.1 & 0.34 & 1,878 & 2.3 & 5,906 & 42.8 & 0.3 & 100.0 & 31.8 \\
\hline Std Dev & 0.1 & 4.5 & 0.03 & 649 & 0.2 & 197 & 1.6 & 4.3 & 0.0 & 0.7 \\
\hline
\end{tabular}

TWR FY04 Week 2 CEMS-MB 

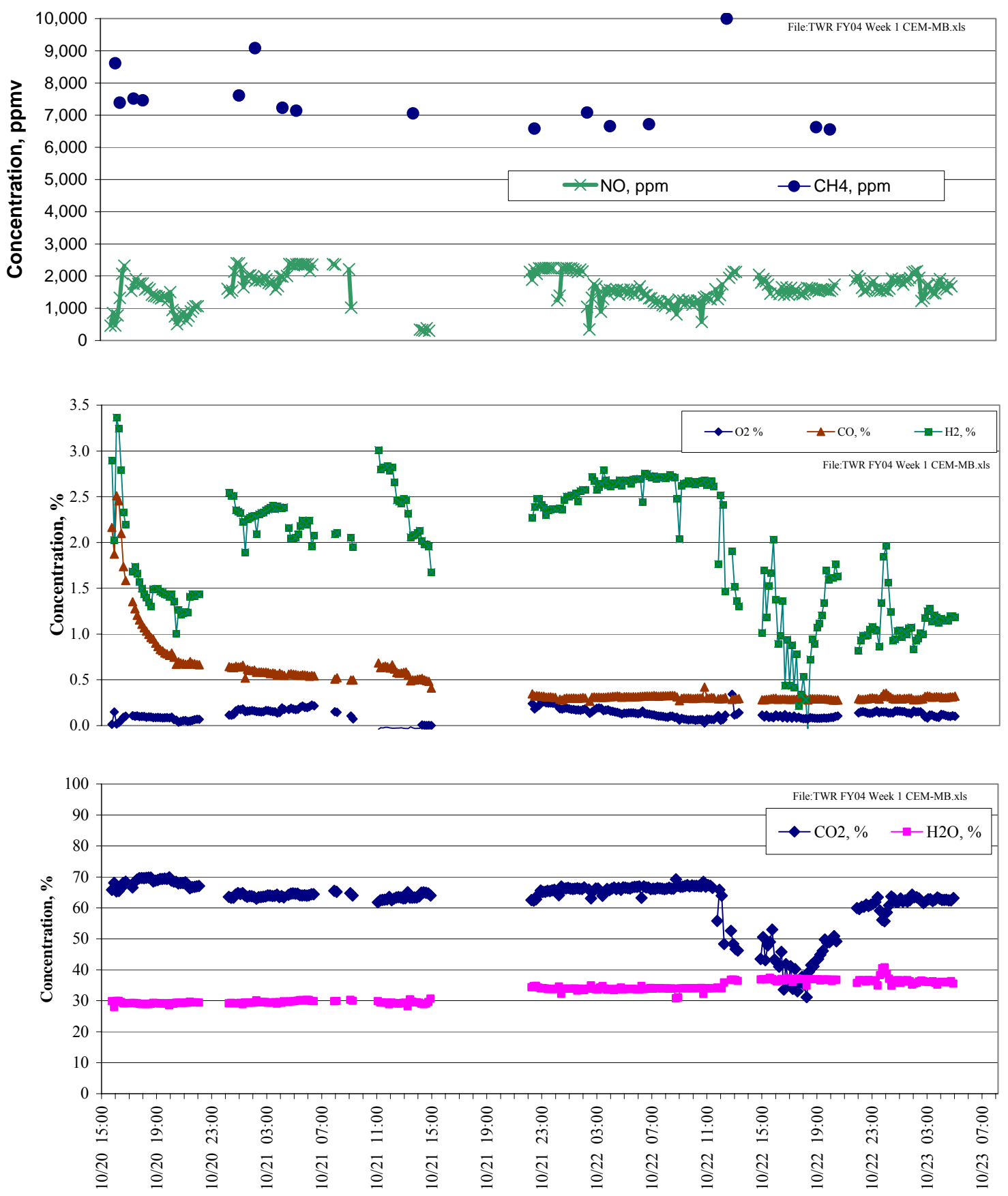

Figure 5.3-1. Wet basis concentrations of $\mathrm{CH}_{4}, \mathrm{NO}, \mathrm{CO}_{2}, \mathrm{H}_{2} \mathrm{O}, \mathrm{O}_{2}, \mathrm{CO}$, and $\mathrm{H}_{2}$ in the off-gas upstream of the oxidizer for the first TWR test week. 

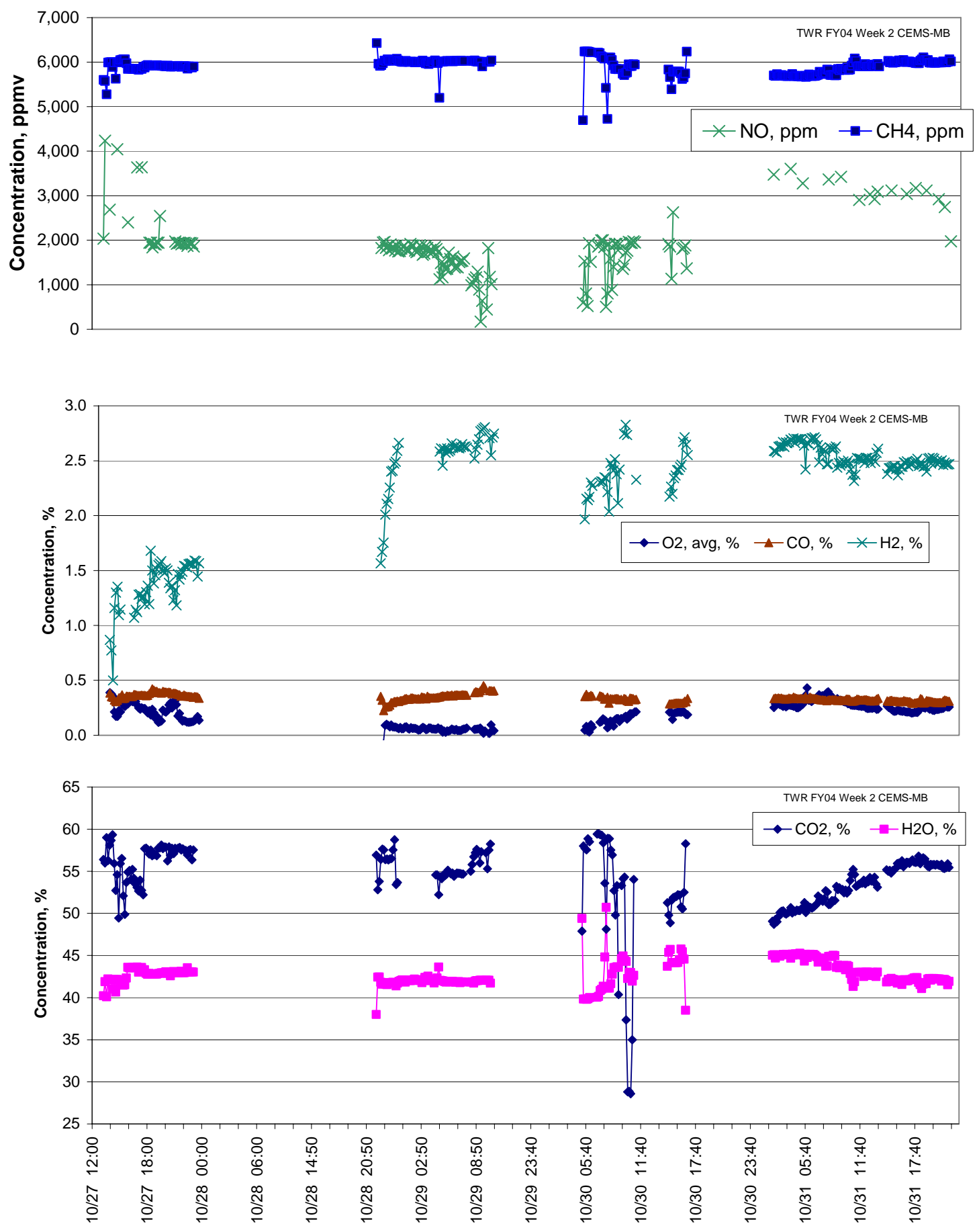

Figure 5.3-2. Wet basis concentrations of $\mathrm{CH}_{4}, \mathrm{NO}, \mathrm{CO}_{2}, \mathrm{H}_{2} \mathrm{O}, \mathrm{O}_{2}, \mathrm{CO}$, and $\mathrm{H}_{2}$ in the off-gas upstream of the oxidizer for the second TWR test week. 
Obtaining high-quality composition measurements for this off-gas is especially challenging due to the presence of moisture, acid gases, and elevated levels of incompletely reacted hydrocarbons and other reduced gas species. The wide range of hydrocarbons and other reduced gas species such as $\mathrm{HCN}$ and $\mathrm{NH}_{3}$ can interfere with measurement methods that are industry standards worldwide for combustion gases. The effects of the various interferences were further mitigated by frequent (daily or more often) calibrations during which calibration factors were recorded. When the calibration factors exceeded EPA acceptance criteria for air emission compliance monitoring, the data were adjusted during post-test data reduction.

The measured wet-basis $\mathrm{O}_{2}$ concentration varied between $0.0-0.2$ vol\%. The presence of $\mathrm{O}_{2}$ was not due to oxygen in the steam reformer off-gas. Rather, it reflects a small amount of air in-leakage into the off-gas system or CEMS downstream of the steam reformer, where the gas temperature was low enough to limit reactions of the available $\mathrm{O}_{2}$ with incompletely oxidized gas species such as $\mathrm{H}_{2}$ or $\mathrm{CH}_{4}$ in the steam reformer off-gas. Approximately, this level of free $\mathrm{O}_{2}$ is typically detected in the test system at the outlet of the heated filter during system leak checks, when no source of $\mathrm{O}_{2}$ is fed to the system. A free $\mathrm{O}_{2}$ concentration of $0.5 \%$ represents an air leak of $\sim 2.5 \%$ of the initial steam reformer gas flow rate.

No zero, span, or interference corrections were necessary for the $\mathrm{O}_{2}$ measurements. In addition to the measured $\mathrm{O}_{2}$ levels from in-leakage, a small amount of measured $\mathrm{O}_{2}$ (perhaps $0.1-0.2 \%$ ) was due to $\mathrm{NO}_{\mathrm{x}}$ interference on the paramagnetic $\mathrm{O}_{2}$ measurement. While this interference is common, it is rarely corrected in industrial applications, and it was not corrected here because the interference was very small.

The Ametek $\mathrm{NO}_{\mathrm{x}}$ analyzer was configured to independently detect both $\mathrm{NO}$ and $\mathrm{NO}_{2}$ using dispersive ultraviolet (DUV) detection. While this analyzer is used reliably worldwide for combustion off-gas measurements and is impervious to the kinds of interferences experienced by chemiluminescent detection used to measure $\mathrm{NO}_{\mathrm{x}}$ concentrations in the prior steam reformer tests (Marshall 2000a and Marshall 2000c), it still experienced other interferences during the steam reforming tests. The levels of incompletely oxidized gas species, which were higher in the steam reformer off-gas than in off-gas from typical industrial combustion processes, caused a positive bias on the $\mathrm{NO}$ and $\mathrm{NO}_{2}$ measurements. The NO measurement was successfully corrected for this bias by subtracting a calibrated value of the interference from the as-measured $\mathrm{NO}$ values. The $\mathrm{NO}_{2}$ measurement was too strongly affected by the interference (compared to the expected $\mathrm{NO}_{2}$ values) and could not be corrected and still provide useable results. Because of this interference, no useable $\mathrm{NO}_{2}$ measurements were obtained during the carbonate test series at the filter outlet location. Because of the magnitude of the zero and interference corrections, the accuracy of the corrected NO data is about $\pm 25 \%$ of the measured values, depending on the test period and the magnitude of the measured values.

$\mathrm{CO}_{2}$ and $\mathrm{H}_{2}$ were measured using a NOVA $\mathrm{CO}_{2} / \mathrm{H}_{2}$ analyzer. The $\mathrm{CO}_{2}$ and $\mathrm{H}_{2}$ data required no zero or span corrections. The calibration from the analyzer (after applicable adjustments) was within the EPA acceptance limits.

The $\mathrm{CH}_{4}$ analyzer experienced no zero calibration error after the installation of the carbon filter in the CEMS 1. No zero or span corrections were necessary during the mineral test series.

$\mathrm{NO}_{\mathrm{x}}$ destruction was also determined for the entire steam reforming test system, using the $\mathrm{NO}$ and $\mathrm{NO}_{\mathrm{x}}$ measurements at the outlet of the thermal oxidizer. These $\mathrm{NO}_{\mathrm{x}}$ destruction values show how a representative, complete, integrated system performs to destroy nitrates in the feed and $\mathrm{NO}_{\mathrm{x}}$ in the offgas. 
5.3.3.2 Off-gas Composition Downstream of the Thermal Oxidizer and Scrubber. The average off-gas composition (wet basis) downstream of the thermal oxidizer and scrubber is shown in Table 5.3-6 for each test condition. All of the CEMS 2 measurements were made on a dry basis after condensing off-gas moisture from the off-gas, except for the $\mathrm{O}_{2}$ measurement. The $\mathrm{O}_{2}$ measurement was made using a heated extractive $\mathrm{ZrO}_{2}$ electrochemical sensor, on a wet basis, for thermal oxidizer process control. Except for the $\mathrm{O}_{2}$ measurement, the wet basis composition was calculated from the dry, asmeasured composition by (a) correcting for zero and span calibration error/drift and (b) normalizing the dry composition to a wet basis using the off-gas moisture content. The wet basis $\mathrm{O}_{2}$ measurement required no calibration corrections.

The moisture content downstream of the scrubber was not directly measured, but was calculated from a dewpoint calculation at the temperature and absolute pressure of the off-gas exiting the wet scrubber. The off-gas moisture content downstream of the scrubber is defined by the scrubber outlet gas dewpoint (except for any water aerosols that remain in the off-gas downstream of the mist eliminator, which could bias the moisture content upward slightly if they are evaporated in the reheater). The moisture content calculations are shown in water mass balance calculations.

The average CEM 2 measurements for $\mathrm{CO}$ and $\mathrm{HCl}$ were converted to a dry, $7 \% \mathrm{O}_{2}$ basis for comparison to the HWC MACT standards. The $\mathrm{CO}$ and $\mathrm{HCl}$ concentrations averaged about $20 \%$ or less of the MACT limits.

\subsection{Fate of Feed Components}

Input and output mass balances were performed to determine the fate of feed components. Key calculations include (a) determination of nitrate and $\mathrm{NO}_{\mathrm{x}}$ destruction, (b) utilization of the organic reductants used to reduce $\mathrm{NO}_{\mathrm{x}}$, and (c) the fate of the main SBW simulant components ( $\mathrm{Na}, \mathrm{Al}$, and $\mathrm{K}$ ), hazardous metals and radionuclide surrogates $(\mathrm{Cr}, \mathrm{Hg}, \mathrm{Pb}, \mathrm{Cs}$, and $\mathrm{Re})$, and anions in the SBW simulant, and (d) overall mass balance closure.

\subsection{1 $\quad \mathrm{NO}_{\mathrm{x}}$ Destruction}

As the SBW simulant and reductants are fed to the steam reformer, the nitrates react with the reductants under steam reformer conditions, converting the nitrogen in the nitrates to predominantly $\mathrm{N}_{2}$. Table 5.4-1 shows $\mathrm{NO}_{\mathrm{x}}$ destruction based on the amount of $\mathrm{NO}$ and $\mathrm{NO}_{2}$ in the off-gas compared to the maximum theoretical emission concentration (MTEC) calculated from the amount of nitrate in the feed. $\mathrm{NO}_{\mathrm{x}}$ destruction trends during the test series are shown in Figure 5.4-1.

$\mathrm{NO}_{\mathrm{x}}$ destruction was calculated several ways. $\mathrm{NO}$ was determined at the steam reformer filter outlet off-gas based on the $\mathrm{NO}_{\mathrm{x}}$ measurements from the CAI NO analyzer. The $\mathrm{NO}_{\mathrm{x}}$ destruction calculations do not account for any $\mathrm{HCN}, \mathrm{N}_{2} \mathrm{O}, \mathrm{NH}_{3}$, or other reduced forms of nitrogen-bearing gas species.

\subsubsection{Reductant Utilization}

The only source of organic carbon in the system was the IPA reductant additive in the feed. The IPA reductant was heated and reacted with available oxidants (nitrates, steam, and $\mathrm{CO}_{2}$ ) in the steam reformer. While the stoichiometry was varied for different test conditions, the overall stoichiometry was always reductant-rich to promote destruction of $\mathrm{NO}_{\mathrm{x}}$. Carbon mass balance closure and distribution to the output streams are shown in Table 5.4-2. 
Table 5.3-6. Off-gas composition downstream of the oxidizer and scrubber for the TWR test series.

\begin{tabular}{|c|c|c|c|c|c|c|c|c|c|c|c|c|c|}
\hline \multirow[b]{2}{*}{$\begin{array}{l}\text { First week test } \\
\text { conditions }\end{array}$} & \multicolumn{12}{|c|}{ Average off-gas composition for each test on a wet basis } & \multirow[b]{2}{*}{$\begin{array}{l}\text { Off-gas } \\
\text { MW }\end{array}$} \\
\hline & $\begin{array}{c}\mathrm{O}_{2}, \\
\%\end{array}$ & $\begin{array}{c}\mathrm{CO}_{2} \\
\%\end{array}$ & $\begin{array}{l}\mathrm{CO}, \\
\mathrm{ppm}\end{array}$ & $\begin{array}{l}\mathrm{NO}, \\
\mathrm{ppm}\end{array}$ & $\begin{array}{l}\mathrm{NO}_{2}, \\
\mathrm{ppm}\end{array}$ & $\begin{array}{l}\mathrm{NO}_{\mathrm{x}}, \\
\mathrm{ppm}\end{array}$ & $\begin{array}{c}\mathrm{H}_{2} \mathrm{O}, \\
\%\end{array}$ & $\begin{array}{l}\text { THC, } \\
\text { ppm }\end{array}$ & $\begin{array}{l}\mathrm{SO}_{2}, \\
\mathrm{ppm}\end{array}$ & $\begin{array}{l}\mathrm{HCl}, \\
\mathrm{ppm}\end{array}$ & $\begin{array}{l}\text { Calc } \\
\mathrm{N}_{2}\end{array}$ & Total, $\%$ & \\
\hline 1.0 & 2.0 & 3.3 & 48 & 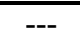 & 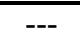 & $-\overline{---}$ & 38.9 & 7.6 & 0 & 0.0 & 55.8 & 100.0 & 24.7 \\
\hline 1.1 & 2.0 & 9.9 & 19 & --- & --- & --- & 36.5 & -0.2 & 0 & 0.0 & 51.5 & 100.0 & 26.0 \\
\hline 2.1 & 2.0 & 10.8 & 12 & --- & --- & --- & 39.8 & -4.5 & 0 & 0.0 & 47.4 & 100.0 & 25.8 \\
\hline 2.2 & 2.0 & 12.7 & 9 & --- & --- & --- & 40.6 & -0.8 & 0 & 0.0 & 44.6 & 100.0 & 26.1 \\
\hline 3.1 & 1.9 & 5.1 & 14 & --- & --- & --- & 40.8 & 1.6 & 1 & 0.0 & 52.2 & 100.0 & 24.8 \\
\hline 3.2 & 2.1 & 2.2 & 8 & --- & --- & --- & 29.6 & 3.8 & 6 & 0.0 & 66.1 & 100.0 & 25.5 \\
\hline 3.3 & 2.0 & 1.6 & 29 & --- & --- & --- & 42.0 & 5.8 & 9 & 0.0 & 54.4 & 100.0 & 24.1 \\
\hline 3.4 & 2.0 & 1.6 & 8 & --- & --- & --- & 40.5 & 3.4 & 10 & 0.0 & 55.9 & 100.0 & 24.3 \\
\hline 3.5 & 2.0 & 1.5 & 5 & --- & --- & --- & 40.5 & 3.6 & 11 & 0.0 & 55.9 & 100.0 & 24.3 \\
\hline 3.6 & 2.0 & 1.5 & 17 & --- & --- & --- & 40.8 & 6.1 & 12 & 0.0 & 55.7 & 100.0 & 24.2 \\
\hline Shutdown & & & & & & & & & & & & & \\
\hline 1.2 & 2.0 & 12.3 & 36 & 207 & 6 & 213 & 39.4 & 2.9 & 4 & 1.1 & 46.3 & 100.0 & 26.1 \\
\hline 1.3 & 2.0 & 14.8 & 28 & 404 & -168 & 235 & 40.1 & 2.4 & 2 & -0.1 & 48.5 & 100.0 & 26.6 \\
\hline 3.7 & 2.5 & 14.3 & 35 & 113 & 24 & 138 & 38.9 & 6.0 & 1 & -0.1 & 44.3 & 100.0 & 26.5 \\
\hline Overall average & 2.0 & 10.1 & 27 & 281 & -77 & 204 & 38.6 & 3.2 & 3 & 0.3 & 50.5 & 100.0 & 25.9 \\
\hline Std Dev & 0.4 & 6.5 & 76 & 344 & 350 & 83 & 7.8 & 12.3 & 3 & 2.7 & 11.2 & 0.0 & 2.2 \\
\hline
\end{tabular}

Notes:

1. Slightly negative $\mathrm{SO}_{2}$ values were truncated to zero.

TWR FY04 Week 1 CEMS-MB

\begin{tabular}{|c|c|c|c|c|c|c|c|c|c|c|c|c|c|}
\hline \multirow{2}{*}{$\begin{array}{c}\text { Week } 2 \\
\text { Test condition }\end{array}$} & \multicolumn{12}{|c|}{ Composition, wet basis } & \multirow[b]{2}{*}{$\begin{array}{c}\text { Off-gas } \\
\text { MW }\end{array}$} \\
\hline & $\begin{array}{l}\mathrm{O}_{2} \\
\%\end{array}$ & $\begin{array}{c}\mathrm{CO}_{2}, \\
\%\end{array}$ & $\begin{array}{l}\mathrm{CO}, \\
\mathrm{ppm}\end{array}$ & $\begin{array}{l}\mathrm{NO}, \\
\text { ppm }\end{array}$ & $\begin{array}{l}\mathrm{NO}_{2}, \\
\mathrm{ppm}\end{array}$ & $\begin{array}{l}\mathrm{NO}_{\mathrm{x}}, \\
\mathrm{ppm}\end{array}$ & $\begin{array}{c}\mathrm{H} 2 \mathrm{O}, \\
\%\end{array}$ & $\begin{array}{l}\text { THC, } \\
\text { ppm }\end{array}$ & $\begin{array}{l}\mathrm{SO}_{2}, \\
\mathrm{ppm}\end{array}$ & $\begin{array}{l}\mathrm{HCl}, \\
\mathrm{ppm}\end{array}$ & $\begin{array}{l}\mathrm{N}_{2} \\
\%\end{array}$ & $\begin{array}{c}\text { Total, } \\
\%\end{array}$ & \\
\hline 5.1 & --- & --- & --- & --- & --- & --- & --- & --- & --- & --- & --- & --- & --- \\
\hline 5.2 & --- & --- & --- & --- & --- & --- & --- & --- & --- & --- & --- & --- & --- \\
\hline 5.3 & --- & --- & --- & --- & --- & --- & --- & --- & --- & --- & --- & --- & --- \\
\hline Shutdown & & & & & & & & & & & & & \\
\hline 5.3 & 3.0 & 9.7 & 30 & 159 & 3 & 162 & 39.5 & 58.5 & 6 & 0.8 & 47.8 & 100.0 & 25.7 \\
\hline Nozzle Plug & & & & & & & & & & & & & \\
\hline $\begin{array}{c}5.3 \\
\text { Nozzle Plug }\end{array}$ & 2.9 & 11.3 & 33 & 136 & 19 & 155 & 40.0 & 2.1 & -5 & 1.8 & 46.5 & 100.0 & 25.8 \\
\hline 5.3 & 2.8 & 11.4 & 62 & 200 & 22 & 221 & 40.3 & -5.0 & -5 & -0.4 & 45.5 & 100.0 & 25.9 \\
\hline 5.3 average & 2.8 & 11.4 & 65 & 202 & 21 & 223 & 40.3 & -5.1 & -5 & -0.3 & 45.5 & 100.0 & 25.9 \\
\hline 5.4 & 2.9 & 11.2 & 8 & 220 & 31 & 251 & 39.9 & 0.0 & -5 & 0.0 & 46.0 & 100.0 & 25.9 \\
\hline Nozzle Plug & & & & & & & & & & & & & \\
\hline 5.4 & 2.9 & 11.2 & 8 & 219 & 30 & 249 & 39.9 & 0.0 & -5 & 0.0 & 45.9 & 100.0 & 25.9 \\
\hline Nozzle Plug & & & & & & & & & & & & & \\
\hline 5.4 & 3.0 & 11.1 & 9 & 247 & 6 & 253 & 39.8 & 0.0 & -6 & 0.0 & 46.1 & 100.0 & 25.9 \\
\hline 5.4 average & 3.0 & 11.1 & 9 & 245 & 8 & 253 & 39.8 & 0.0 & -6 & 0.0 & 46.1 & 100.0 & 25.9 \\
\hline Overal average & 3.0 & 11.5 & 18 & 222 & 9 & 231 & 39.8 & 11.5 & -3 & -0.5 & 46.5 & 100.0 & 25.9 \\
\hline Std Dev & 0.2 & 2.4 & 75 & 46 & 31 & 46 & 0.5 & 152.5 & 6 & 10.5 & 1.8 & 0.0 & 0.3 \\
\hline
\end{tabular}

TWR FY04 Week 2 CEMS-MB 
Table 5.4-1. $\mathrm{NO}_{\mathrm{x}}$ destruction for the TWR test series.

\begin{tabular}{|c|c|c|c|c|c|c|c|c|c|c|c|c|c|c|}
\hline \multirow[b]{2}{*}{ Test condition } & \multirow[b]{2}{*}{$\begin{array}{l}\text { Simulant } \\
\text { feedrate, } \\
\mathrm{L} / \mathrm{hr}\end{array}$} & \multirow[b]{2}{*}{$\begin{array}{c}\mathrm{NO}_{\mathrm{x}} \\
\text { feedrate, } \\
\text { scfm }\end{array}$} & \multicolumn{4}{|c|}{ CEM 1 off-gas at steam reformer heated filter } & \multicolumn{8}{|c|}{ CEM2 } \\
\hline & & & $\begin{array}{c}\text { Off-gas flowrate at } \\
\text { the filter outlet, } \\
\text { wscfm }\end{array}$ & $\begin{array}{c}\mathrm{NO}_{\mathrm{x}} \\
\mathrm{MTEC}, \\
\text { wet ppm }\end{array}$ & $\begin{array}{c}\mathrm{NO} \text {, wet } \\
\mathrm{ppm}\end{array}$ & $\begin{array}{c}\% \text { NO } \\
\text { removal }\end{array}$ & $\begin{array}{l}\text { Off-gas flow } \\
\text { to GAC inlet, } \\
\text { wscfm } \\
\end{array}$ & $\begin{array}{c}\mathrm{NO}_{\mathrm{x}} \\
\mathrm{MTEC}, \\
\text { wet ppm } \\
\end{array}$ & $\begin{array}{c}\mathrm{NO}, \text { wet } \\
\mathrm{ppm}\end{array}$ & $\begin{array}{c}\mathrm{NO}_{2}, \\
\text { wet ppm }\end{array}$ & $\begin{array}{c}\mathrm{NO}_{\mathrm{x}}, \\
\text { wet ppm }\end{array}$ & \begin{tabular}{|c|}
$\begin{array}{c}\text { Total system } \\
\text { NO removal, } \\
\%\end{array}$ \\
\end{tabular} & $\begin{array}{c}\text { Total system } \\
\text { NO }_{\mathrm{x}} \\
\text { removal, \% } \\
\end{array}$ & $\begin{array}{c}\mathrm{NO}_{\mathrm{x}} \text { destruction } \\
\text { by thermal } \\
\text { oxidizer, \% }\end{array}$ \\
\hline 1.0 & 1.59 & 0.10 & 12.8 & 7,649 & 639 & 91.6 & 60 & 1,632 & --- & --- & --- & --- & $\overline{---}$ & --- \\
\hline 1.1 & 2.01 & 0.12 & 12.3 & 9,904 & 1,713 & 82.7 & 59 & 2,073 & --- & --- & --- & --- & --- & --- \\
\hline 2.1 & 2.01 & 0.12 & 12.2 & 9,899 & 1,393 & 85.9 & 58 & 2,083 & --- & --- & --- & --- & --- & --- \\
\hline 2.2 & 2.00 & 0.12 & 12.1 & 10,050 & 975 & 90.2 & 59 & 2,073 & --- & --- & --- & --- & --- & --- \\
\hline 3.1 & 2.53 & 0.16 & 11.9 & 13,271 & 1,933 & 85.3 & 57 & 2,749 & --- & --- & --- & --- & --- & --- \\
\hline 3.2 & 3.00 & 0.19 & 11.5 & 16,160 & 2,242 & 86.2 & 58 & 3,191 & --- & --- & --- & --- & --- & --- \\
\hline 3.3 & 1.72 & 0.11 & 12.5 & 8,605 & 1,023 & 93.7 & 63 & 2,288 & --- & --- & --- & --- & --- & --- \\
\hline 3.4 & 1.62 & 0.10 & 12.9 & 7,602 & --- & -- & --- & --- & --- & --- & --- & --- & --- & --- \\
\hline 3.5 & 1.80 & 0.11 & 12.6 & 8,687 & 339 & 96.7 & --- & --- & --- & --- & -- & --- & --- & --- \\
\hline \multirow{2}{*}{\multicolumn{15}{|c|}{ Shutdown }} \\
\hline & & & & & & & & & & & & & & \\
\hline 1.2 & 3.26 & 0.20 & 16.7 & 12,104 & 1,562 & 86.8 & 63 & 3,220 & 207 & 6 & 213 & 93.2 & 93.1 & 34.1 \\
\hline 1.3 & 3.99 & 0.24 & 19.3 & 12,534 & 1,693 & 86.4 & 75 & 3,221 & 256 & -8 & 248 & 93.0 & 93.0 & 50.7 \\
\hline 3.7 & 3.54 & 0.21 & 19.7 & 10,844 & 1,665 & 84.7 & 69 & 3,065 & 228 & -8 & 221 & 92.6 & 92.8 & 52.0 \\
\hline Overall average & 2.99 & 0.18 & 15.6 & 11,795 & 1,606 & 86.7 & 65 & 2,945 & 236 & -3 & 233 & 93.0 & 93.0 & 45.0 \\
\hline Std Dev & 0.85 & 0.05 & 3.2 & 2,212 & 474 & 3.4 & 7 & 524 & 56 & 34 & 49 & 0.7 & 0.4 & 13.1 \\
\hline \multicolumn{15}{|c|}{ TWR FY04 Week 1 CEMS-MS } \\
\hline 5.1 & 3.6 & 0.22 & 14.5 & 14,755 & 3,249 & 77.6 & 80 & 2,797 & --- & --- & --- & --- & --- & --- \\
\hline 5.2 & 3.6 & 0.22 & 13.4 & 16,064 & 2,400 & 85.5 & 63 & 3,443 & --- & --- & --- & --- & --- & --- \\
\hline 5.3 & 3.6 & 0.22 & 11.8 & 18,288 & 2,029 & 89.0 & 65 & 3,338 & --- & --- & --- & --- & --- & --- \\
\hline Shutdown & & & & & & & & & & & & & & \\
\hline 5.3 & 3.6 & 0.22 & 11.9 & 18,190 & 1,574 & 91.3 & --- & --- & 159 & 4 & 162 & --- & --- & --- \\
\hline Nozzle Plug & & & & & & & & & & & & & & \\
\hline 5.3 & 3.3 & 0.24 & 10.0 & 20,013 & 1,150 & 93.5 & --- & --- & 136 & 19 & 155 & --- & --- & --- \\
\hline Nozzle Plug & & & & & & & & & & & & & & \\
\hline 5.3 & 4.4 & 0.28 & 13.4 & 20,330 & 1,678 & 91.4 & --- & --- & 200 & 22 & 221 & --- & --- & --- \\
\hline 5.3 average & 4.5 & 0.28 & 13.5 & 20,444 & 1,670 & 91.4 & --- & --- & 202 & 21 & 223 & --- & --- & --- \\
\hline 5.4 & 4.4 & 0.27 & 14.4 & 18,466 & 1,802 & 90.4 & 67 & 4,014 & 214 & 61 & 275 & 94.4 & 93.7 & 31.1 \\
\hline Nozzle Plug & & & & & & & & & & & & & & \\
\hline 5.4 & 4.4 & 0.27 & 14.5 & 18,565 & 1,786 & 90.6 & 67 & 4,043 & 208 & 52 & 260 & 94.5 & 93.8 & 31.0 \\
\hline Nozzle Plug & & & & & & & & & & & & & & \\
\hline 5.4 & 4.2 & 0.25 & 14.2 & 17,259 & 3,073 & 82.0 & 67 & 3,647 & 247 & 5 & 252 & 93.0 & 92.9 & 59.5 \\
\hline 5.4 average & 4.2 & 0.25 & 14.2 & 17,357 & 2,650 & 84.8 & 67 & 3,685 & 244 & 10 & 254 & 93.1 & 93.0 & 50.1 \\
\hline Overal average & 3.4 & 0.24 & 11.3 & 17,808 & 1,878 & 89.5 & 67 & 3,563 & 221 & 10 & 232 & 93.1 & 93.0 & 50.1 \\
\hline Std Dev & 1.6 & 0.03 & 5.2 & 1,834 & 649 & 4.0 & 1 & 186 & 47 & 38 & 48 & 0.8 & 0.6 & 19.0 \\
\hline
\end{tabular}



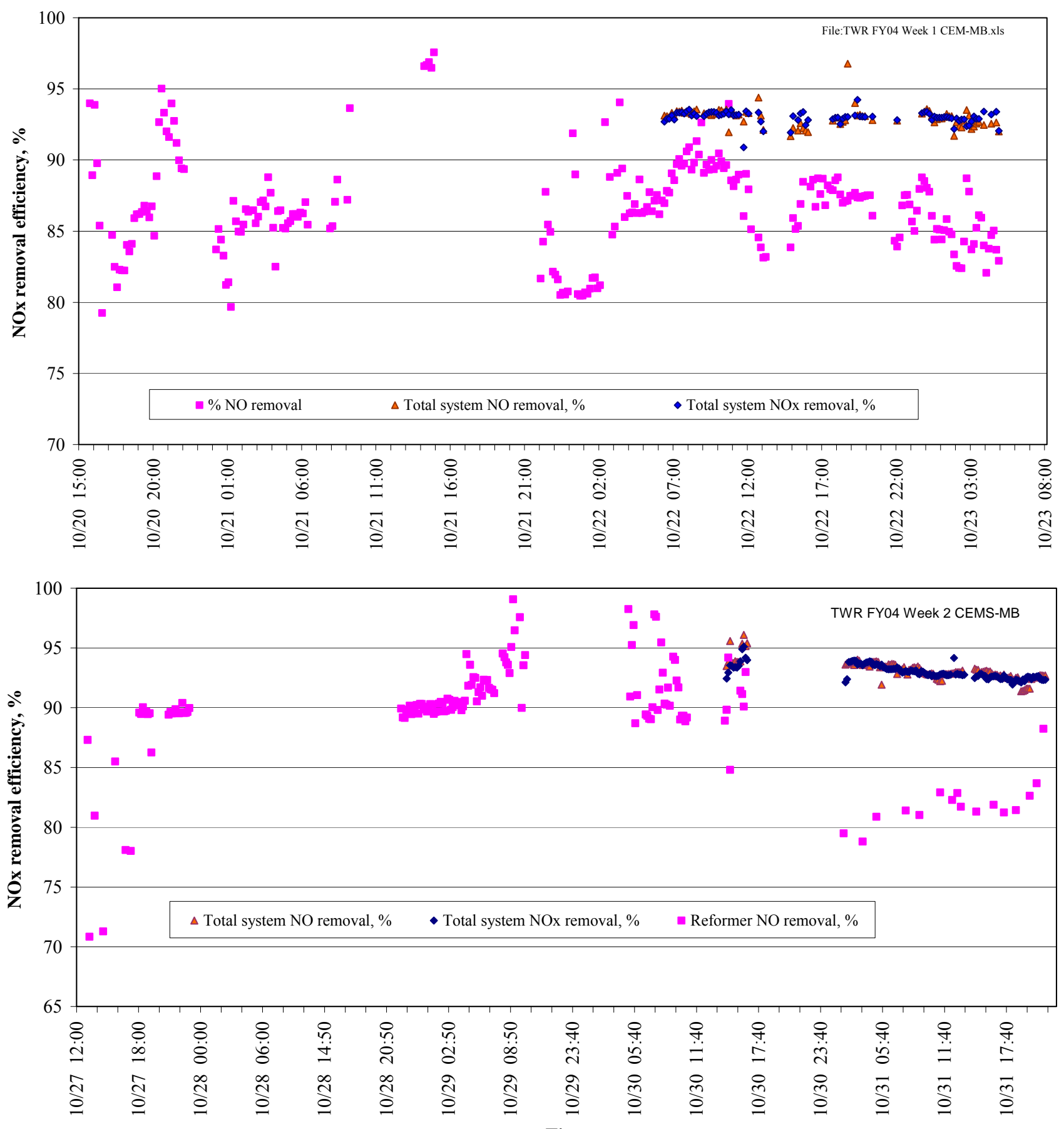

Figure 5.4-1. $\mathrm{NO}_{\mathrm{x}}$ destruction for the TWR test series. 
Table 5.4-2. Carbon mass distribution and balance for the TWR test series week 2.

\begin{tabular}{|c|c|c|c|c|c|c|c|c|c|c|}
\hline & \multicolumn{2}{|c|}{ Carbon mass input, } & \multicolumn{7}{|c|}{ Carbon mass outputs, kg (a) } \\
\hline & & \multirow[b]{2}{*}{$\begin{array}{c}\text { From } \\
\mathrm{CO} 2 \text { gas }\end{array}$} & \multirow[b]{2}{*}{ From IPA } & \multicolumn{3}{|c|}{ Solid outputs } & \multirow[b]{2}{*}{$\begin{array}{l}\text { Scrub } \\
\text { water }\end{array}$} & \multicolumn{3}{|c|}{ Off-gas at the filter outlet } \\
\hline & & & & $\begin{array}{c}\text { Bed } \\
\text { product }\end{array}$ & $\begin{array}{l}\text { Cyclone } \\
\text { samples }\end{array}$ & $\begin{array}{l}\text { Filter } \\
\text { catch }\end{array}$ & & $\mathrm{CO} 2$ & $\mathrm{CO}$ & $\begin{array}{l}\mathrm{THC} \\
\text { (c) }\end{array}$ \\
\hline \multirow[b]{2}{*}{$\begin{array}{l}\text { Totals of } \\
\text { individual } \\
\text { streams } \\
\end{array}$} & $\begin{array}{l}\text { Total organic } \\
\text { (reduced) carbon } \\
\text { (TOC) }\end{array}$ & 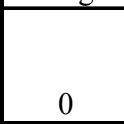 & 171 & 0.05 & 0.08 & 0.12 & 0.0007 & 0.00 & 4.00 & 8.00 \\
\hline & $\begin{array}{l}\text { Total inorganic } \\
\text { (fully oxidized) } \\
\text { carbon (TIC) }\end{array}$ & 520 & 0 & 3.0 & 0.16 & 0.07 & 0.0006 & 657 & 1.8 & 0.00 \\
\hline \multirow[b]{2}{*}{ Input/output } & TOC & 0 & 171 & & 0.2 & & 0.0007 & & 12.0 & \\
\hline & TIC & 520 & --- & & 3.2 & & 0.0006 & & 659 & \\
\hline \multicolumn{2}{|c|}{ Total input/output } & \multicolumn{2}{|c|}{691} & \multicolumn{7}{|c|}{674} \\
\hline \multicolumn{2}{|c|}{$\begin{array}{l}\text { Total carbon mass balance closure, } \\
\% \text { (b) }\end{array}$} & \multicolumn{9}{|c|}{98} \\
\hline
\end{tabular}

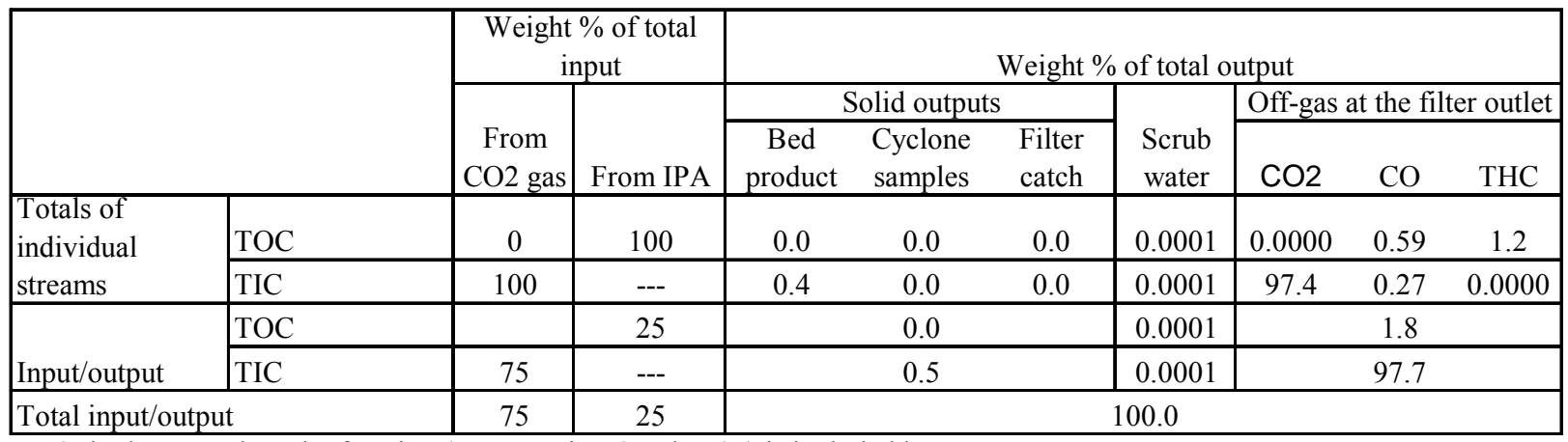

a. Only the second week of testing (commencing October 27) is included here.

b. Total mass of the carbon output streams divided by the mass of the carbon input stream.

c. Total hydrocarbon concentrations were well below the noise level of the other off-gas carbon measurements.

[C balance for TWR.xIs]Sheet1

Most of the effluent carbon ( $>98 \%$ ) was in the off-gas $\mathrm{CO}_{2}, \mathrm{CO}$, or THC. Only $1.7 \%$ of the carbon was found in the solid products, and a negligible amount $(<0.001 \%)$ was found in the wet scrubber. Of the carbon in the solid output streams, most was in the form of inorganic carbon in the bed product.

Smaller amounts were found as organic and inorganic carbon in the cyclone and filter material outputs. Progressively larger quantities of organic carbon were found in the products between the bed, cyclone, and filter solids. Organic carbon constituted significantly higher weight fractions of the cyclone material $(0.6-2.1 \mathrm{wt} \%)$ and filter material $(4.1-6.5 \mathrm{wt} \%)$ than of the bed product $(<0.1 \mathrm{wt} \%)$.

\subsubsection{Product Elemental Distribution and Mass Balance Closure}

The SBW simulant components, hazardous metals, radionuclide surrogates, and anions partition in different ways among the solid and gaseous effluents of the steam reformer. Most of the condensable and water-soluble gas species, and fine particulate matter (PM) that pass through the heated filter, may be scrubbed into the wet scrub solution. Other species, which tend to form more refractory compounds, are likely to be retained in bulk solid products.

Input and output measurements and calculations were made in the current tests to determine the distribution of the feed constituents to the reformer products. The product distributions are shown in Table 5.4-3. The total solid mass partitioned about $94 \%$ to the bed product, $3.7 \%$ to the cyclone fines, and $1.8 \%$ to the filter fines. Partitioning of material to the scrub water was negligible $(<0.02 \%)$. 
Species that appeared to partition in the same manner as the total solids to the bed product, filter fines, and off-gas were those that (a) partitioned between greater than about $50 \%$ to the bed product, and between $0-20 \%$ to the cyclone material and filter fines, and (b) had mass balance closure ratios greater than about 0.5 . Most of the species in the feed partitioned primarily to the bed product.

Species that tend to volatilize and then be captured in the cyclone recycle and filter fines are those that (a) had mass distributions to the bed less than about 50\% and mass distributions to the cyclone material and filter fines greater than about 50\%, and (b) had mass balance closure ratios of at least 0.5 . No species clearly met these criteria, although several $(\mathrm{Cl}, \mathrm{F}, \mathrm{Cs}, \mathrm{Pb}$, and $\mathrm{Re})$ partitioned more to the fines than other species did.

A number of species exhibited low mass balance closure ratios. These species were those that either (a) tend to volatilize into a form (either a gas species or particulate matter (PM) too small to be captured in the heated filter) and are also not readily wet scrubbed, or (b) are difficult to dissolve during sample analysis and thus had analytical recoveries that were low and not representative of the true concentrations in the samples. Nitrate and $\mathrm{Hg}$ are species with low mass balance closure ratios. Corroborating test results show that the $\mathrm{NO}_{3}$ was destroyed with an average efficiency of about $99.8 \%$. The small remaining amount of $\mathrm{NO}_{3}$ partitioned mainly to the bed product with lesser amounts in the cyclone material and the filter fines. Less than $1 \%$ of the measured output nitrate was in the scrub water. With $<0.01 \%$ of the input $\mathrm{Hg}$ measured in the scrub water, essentially $100 \%$ of the $\mathrm{Hg}$ partitioned to the off-gas and was ultimately captured in the GAC beds.

Some species had low enough mass balance closure ratios that the sample recovery during sample analysis is suspect. Those species included $\mathrm{F}, \mathrm{Al}, \mathrm{Cu}, \mathrm{Sn}$, and $\mathrm{Zr}$. While the low mass balance ratio for $\mathrm{F}$ may conceivably (though not likely) have been because of conversion to HF and not efficiently scrubbed in the scrubber, $\mathrm{Al}$ and $\mathrm{Zr}$ are far less volatile and less likely to pass through the heated filter. The heated filter exhibited a total particulate capture efficiency of $\sim 99 \%$.

A reasonable explanation for the low mass balance closure ratios for $\mathrm{F}, \mathrm{Al}, \mathrm{Cu}, \mathrm{Sn}$, and $\mathrm{Zr}$ is low analytical recoveries due to dissolution procedures, which were not sufficiently aggressive for insoluble mineral species formed in the reformer. Such species may also have bound some of the other cations and anions. This may be why mass balance closure ratios range between about 0.6 to 0.9 for several other species $(\mathrm{Cs}, \mathrm{Pb}, \mathrm{Re}$, and $\mathrm{Si})$. Even though the mass balance closure ratios are less than unity for these other species, the mass balance closure ratios are close enough to unity so that conclusions about the product distributions of these other species are reasonably valid.

A few other species $\left(\mathrm{SO}_{4}, \mathrm{Cl}, \mathrm{Cr}, \mathrm{Fe}, \mathrm{K}, \mathrm{Na}, \mathrm{Ni}\right.$, and $\left.\mathrm{Zn}\right)$ have mass balance closures above 1.1. The product sample analyses for these species may have been accurate, but the input levels may be higher than estimated based on the SBW simulant recipe. Some of these species were present at relatively low levels in the simulant. Any unaccounted-for impurities in the reagents used to make the simulant, the solid carbon reductant, or the starting bed media could bias the mass balance closure upward for these species. In this case, the distributions to the output streams for these species, based on the output measurements, is still considered valid. Mass balance closures exceeding unity for dominant species such as $\mathrm{Na}$ and $\mathrm{K}$ are close to typical analytical uncertainties $( \pm 20 \%)$ and may be solely attributable to this error source. Partitioning conclusions regarding these species are, therefore, also considered valid. 
Table 5.4-3. Elemental distributions and mass balance closure for the TWR test series.

\begin{tabular}{|c|c|c|c|c|c|c|c|c|c|c|c|c|c|c|c|c|c|c|c|c|c|c|c|c|}
\hline \multicolumn{25}{|c|}{ Mass, kg } \\
\hline & Total & NO3 & $\mathrm{PO} 4$ & $\mathrm{SO} 4$ & $\mathrm{Cl}$ & $\mathrm{F}$ & $\mathrm{Al}$ & $\mathrm{Ca}$ & $\mathrm{Cr}$ & $\mathrm{Cs}$ & $\mathrm{Cu}$ & $\mathrm{Fe}$ & $\mathrm{Hg}$ & $\mathrm{K}$ & $\overline{\mathrm{Mg}}$ & $\mathrm{Mn}$ & $\mathrm{Na}$ & $\mathrm{Ni}$ & $\mathrm{Pb}$ & $\operatorname{Re}$ & $\overline{\mathrm{Si}}$ & $\mathrm{Sn}$ & $\mathrm{Zn}$ & $\mathrm{Zr}$ \\
\hline \multicolumn{25}{|l|}{ Input streams: } \\
\hline Starting bed media & 70 & & 3.E-04 & 0.344 & 0.054 & 0.015 & 25.2 & 0.062 & 0.009 & 0.011 & 0.002 & 0.047 & 0 & 0.373 & 0.015 & 0.04 & 2.812 & 0.005 & 0.007 & 0.002 & 0.006 & $1 \mathrm{E}-04$ & 0.004 & $8 \mathrm{E}-04$ \\
\hline Feed solids & 32 & & 0.63 & 1.47 & 0.24 & 0.10 & 3.9 & 0.42 & 0.038 & 0.093 & 0.010 & 0.27 & 0.059 & 1.66 & 0.065 & 0.17 & 10.32 & 0.019 & 0.059 & 0.043 & 0.03 & 0.011 & 0.015 & 0.007 \\
\hline Total inputs & 101.7 & 72.04 & 0.63 & 1.81 & 0.29 & 0.11 & 29.1 & 0.48 & 0.046 & 0.104 & 0.011 & 0.31 & 0.059 & 2.03 & 0.080 & 0.21 & 13.13 & 0.023 & 0.066 & 0.045 & 0.04 & 0.012 & 0.019 & 0.008 \\
\hline $\begin{array}{l}\text { Output streams: } \\
\text { Bed product }\end{array}$ & 95.39 & 0.112 & 0.00 & 2.36 & 0.28 & 0.020 & 4.6 & 0.43 & 0.053 & 0.052 & 0.003 & 0.33 & NM & 2.36 & 0.109 & 0.182 & 15.30 & 0.027 & 0.033 & 0.013 & 0.020 & 0.000 & 0.022 & 0.003 \\
\hline Cyclone product & 3.77 & 0.027 & 0.00 & 0.13 & 0.04 & 0.01 & 0.2 & 0.01 & 0.003 & 0.013 & 0.000 & 0.02 & NM & 0.13 & 0.003 & 0.01 & 0.64 & 0.002 & 0.005 & 0.006 & 0.003 & 0.000 & 0.001 & 0.000 \\
\hline Filter fines & 1.86 & 0.006 & 0.00 & 0.08 & 0.08 & 0.02 & 0.1 & 0.01 & 0.002 & 0.020 & 0.000 & 0.01 & NM & 0.09 & 0.003 & 0.01 & 0.25 & 0.001 & 0.005 & 0.009 & 0.002 & 0.000 & 0.001 & 0.000 \\
\hline Scrub solids & 0.01 & 0.001 & 0.00 & 0.00 & 0.00 & 0.00 & 0.0 & 0.00 & 0.000 & 0.000 & 0.000 & 0.00 & $2 \mathrm{E}-06$ & 0.00 & 0.000 & 0.000 & 0.00 & 0.000 & 0.000 & 0.000 & -0.003 & 0.000 & 0.000 & 0.000 \\
\hline Total outputs & 101.0 & 0.147 & 0.00 & 2.58 & 0.40 & 0.04 & 4.9 & 0.45 & 0.058 & 0.086 & 0.004 & 0.36 & $2 \mathrm{E}-06$ & 2.58 & 0.115 & 0.20 & 16.19 & 0.031 & 0.043 & 0.028 & 0.022 & 0.000 & 0.024 & 0.003 \\
\hline \multicolumn{25}{|c|}{ Elemental mass distribution, $\%$ of mass in the output stream divided by total mass in the total of all output streams } \\
\hline$\overline{B e d ~ p r}$ & 94.4 & 76.3 & 94.4 & 91.6 & 71.2 & 44.5 & 94.2 & 95.0 & 92.0 & 61.1 & 86.2 & $\overline{91.5}$ & $\overline{\mathrm{NM}}$ & 91.5 & 94.8 & 90.5 & 94.5 & 89.1 & 76.6 & 47.5 & 86.9 & 92.2 & 90.8 & 86. \\
\hline Cyclone samples & 3.7 & 18.4 & 3.7 & 5.0 & 9.2 & 12.3 & 3.4 & 2.9 & 4.5 & 15.0 & 9.3 & 5.1 & NM & 5.0 & 2.8 & 6.5 & 4.0 & 6.9 & 12.7 & 21.2 & 15.5 & 5.8 & 5.0 & 8. \\
\hline Filter fines & 1.8 & 4.4 & 1.8 & 3.2 & 19.2 & 36.9 & 2.4 & 2.3 & 3.5 & 23.9 & 4.4 & 3.3 & NM & 3.5 & 2.5 & 3.0 & 1.5 & 4.0 & 10.7 & 31.2 & 8.9 & 2.0 & 3.3 & 2. \\
\hline Scrub solution & 0.0 & 1.0 & 0.0 & 0.2 & 0.4 & 6.3 & 0.0 & -0.2 & 0.0 & 0.0 & 0.1 & 0.0 & NM & 0.0 & -0.1 & 0.0 & 0.0 & 0.1 & 0.0 & 0.1 & -11.2 & 0.0 & 0.9 & 2. \\
\hline Total outputs & 100.0 & 100.0 & 100.0 & 100.0 & 100.0 & 100.0 & 100.0 & 100.0 & 100.0 & 100.0 & 100.0 & 100.0 & --- & 100.0 & 100.0 & 100.0 & 100.0 & 100.0 & 100.0 & 100.0 & 100.0 & 100.0 & 100.0 & 100.0 \\
\hline
\end{tabular}

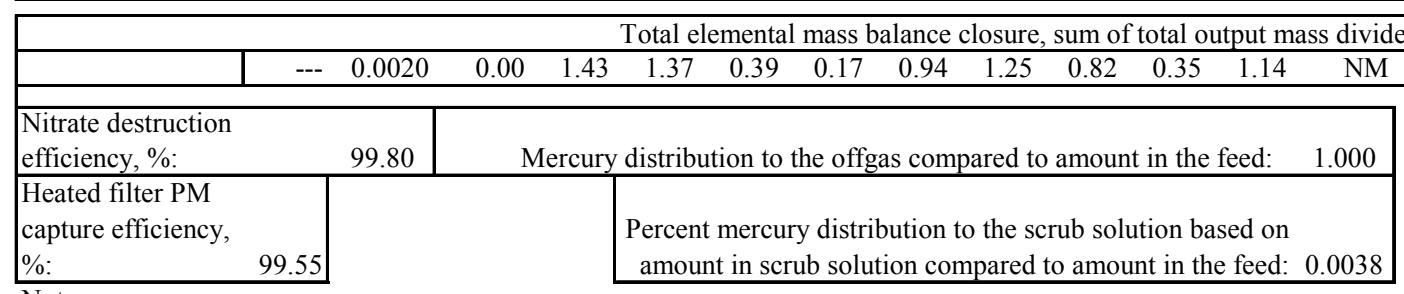

Notes:

amount in scrub solution compared to amount in the feed: 0.0038

1. Impurities of the starting bed media and in the solid carbon reductant are not included.

2. The calculated total mass of feed solids is based on the theoretical product composition in Table 5.3-1.

3. The input mass of nitrate and $\mathrm{Hg}$ were included (even though the solid product calculations assumed that all NO3 and Hg would evolve to the offgas) in order to perform mass balance closure calculations for these species.

4. The mass of any material (especially $\mathrm{Hg}$, and possibly some halides, $\mathrm{P}$, and $\mathrm{S}$ ) captured in the carbon bed is not included. This may be the cause for mass balance closures significantly less than 1.0 for some species (PO4, $\mathrm{SO} 4, \mathrm{Fe}$, and $\mathrm{Si}$ ).

5. The mass balance closure calculations are based on the solid product masses and their measured compositions, together with the measured composition of the scrub liquor. Any elemental masses that leave the system in the offgas after passing through the cyclone, filter, and scrubber are not accounted for

6. The volume of the scrub solution averaged 45 gallons. The total mass of undissolved and dissolved solids in the scrub solution is the sum of the elements and measured species, excluding any oxide mass.

7. The nitrate destruction efficiency is calculated from the total amount of output NO3 compared to the total input amount of NO3.

8. The heated filter particulate matter (PM) removal efficiency was estimated from the amount of total elemental solids captured in the wet scrubber compared the mass of filter fines.

9. PO4 was not measured in the solid products.

9. $\mathrm{NM}=$ "not measured" 


\subsubsection{Off-gas Mercury Concentrations and Emissions Control}

Mercury is a unique hazardous metal because of its toxicity and its volatility. It was expected that essentially no $\mathrm{Hg}$ would be retained in any of the solid products, though this speculation was not confirmed with sample analyses. It was assumed that the $\mathrm{Hg}$ in the SBW simulant feed quantitatively evolved to the steam reformer off-gas. Table 5.4-4 shows the speciation and concentrations of $\mathrm{Hg}$ as the off-gas passed through the wet scrubber and 3-stage carbon bed. This table also shows the mass balance closure and carbon bed sorption efficiency.

The carbon bed was designed with three stages in order to (a) show the potential loading capacity (mass of total $\mathrm{Hg}$ sorbed per mass of carbon sorbent) and (b) the potential total $\mathrm{Hg}$ removal efficiency from the steam reformer off-gas. These two objectives are mutually exclusive in discrete small-scale pilot tests. The theoretical sorption capacity for Nucon sulfur-impregnated carbon is up to $20 \mathrm{wt} \%$, so a carbon bed for discrete small-scale pilot tests would need to be too small to be appropriately designed according to vendor recommendations and design criteria for maximum superficial velocity, minimum residence time, and geometry (Soelberg 2003b).

The three-stage design enables both objectives to be accomplished. The first (3-inch deep) stage, while not designed with appropriate depth-to-diameter dimensions or residence time, has an appropriate superficial gas velocity and a small enough mass of carbon so that its capacity may be reached (defined by when breakthrough occurs) in a reasonable test duration. The $\mathrm{Hg}$ removal efficiency data confirm that the first stage is in fact not designed appropriately for ultra high $\mathrm{Hg}$ removal efficiency. The first stage removed about $97 \%$ of the total $\mathrm{Hg}$ (compared with $>99.8 \%$ for the three stages combined).

Breakthrough occurs when the outlet $\mathrm{Hg}$ levels start to increase from a relatively constant baseline level, asymptotically approaching the inlet level. By design, the first stage did not reach breakthrough during the TWR test series. However, the carbon capacity is not less than the measured value for total $\mathrm{Hg}$ content in the carbon at the time the TWR test series ended (3.9 wt $\%)$.

The combined first, second, and third stages have sufficient depth to meet vendor recommendations and design criteria. The Hg removal efficiency shown at the end of the second and third stages confirms that this bed design accomplishes very efficient $\mathrm{Hg}$ control. The $\mathrm{Hg}$ concentrations downstream of stages 2 and 3, corrected to a dry, $7 \% \mathrm{O}_{2}$ basis, are less than $50 \%$ of the HWC MACT limit.

Manual sample trains based on the Ontario Hydro Mercury Method were performed to measure offgas $\mathrm{Hg}$ concentrations at the inlet and the outlet of the carbon bed. Results are shown in Table 5.4-5, compared to the Hg CEMS measurements and the Hg MTEC at the inlet of the carbon bed. The average of the CEMS and manual sample train measurements agrees with a relative percent difference of $13 \%$ with the MTEC at the inlet of the carbon bed. The carbon bed outlet sample train measurements confirm the low levels indicated by the Hg CEMS. 
Table 5.4-4. Hg speciation, concentrations, mass balance closure, and carbon bed sorption efficiency for the TWR test series.

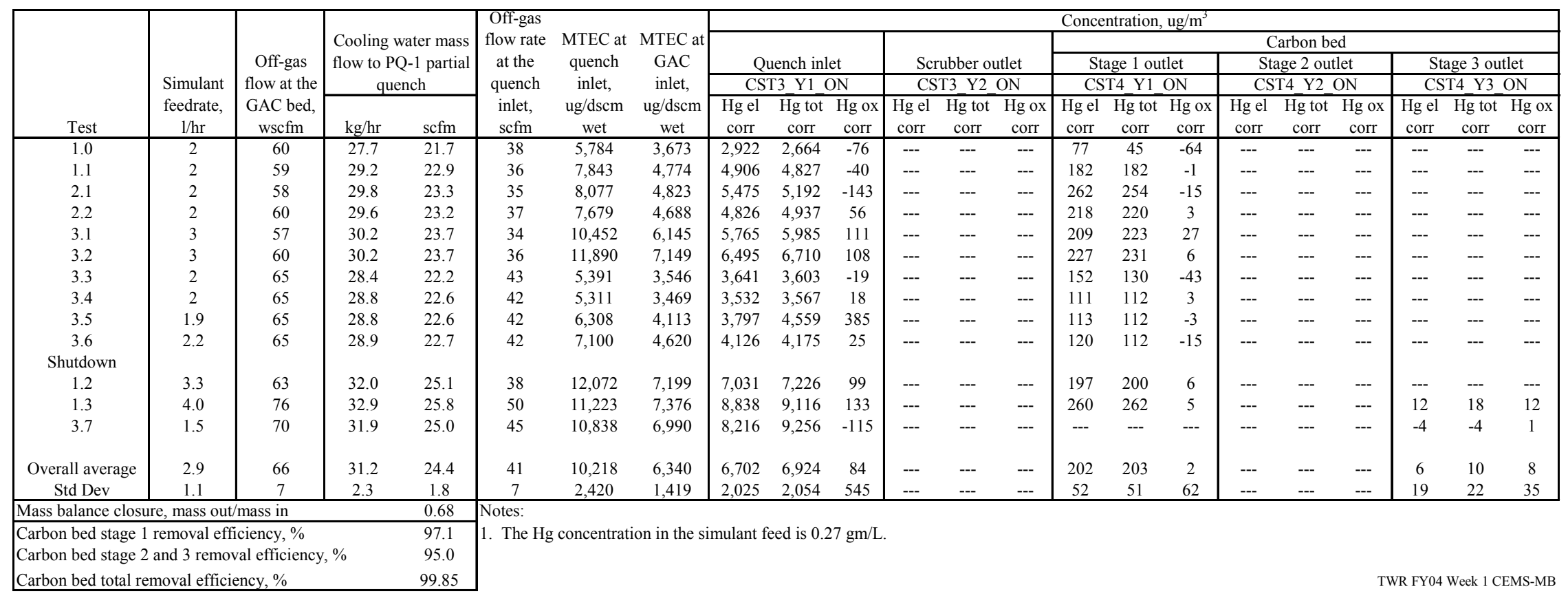

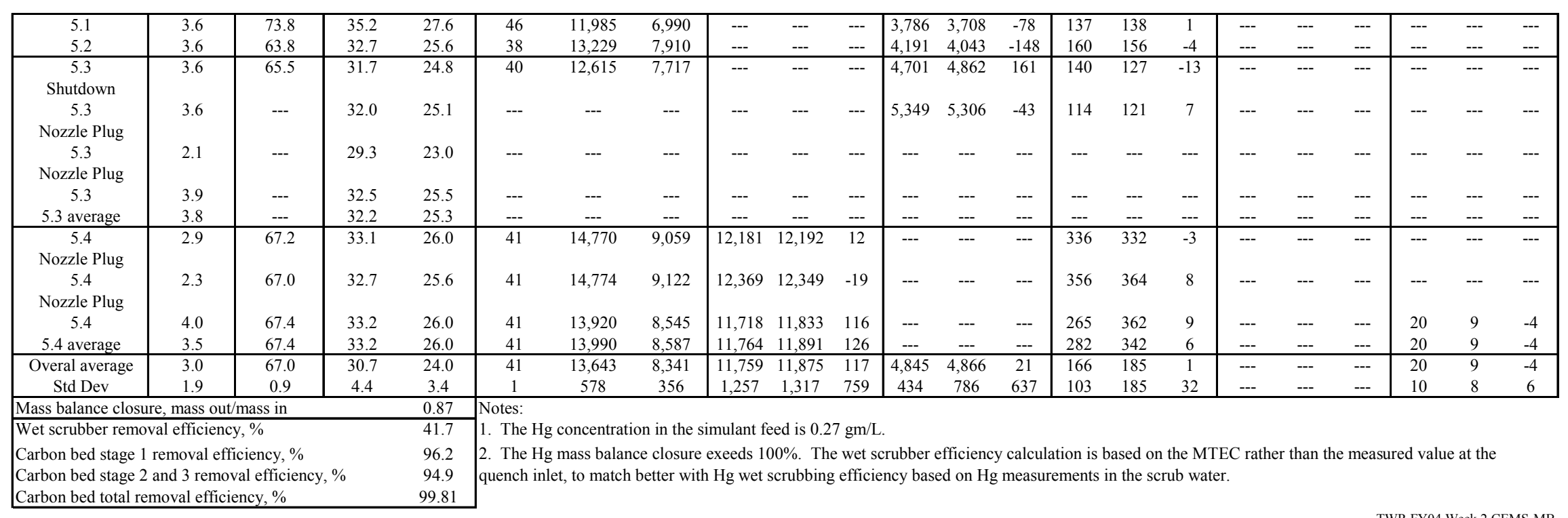


Table 5.4-5. Hg CEMS and manual sample train measurements.

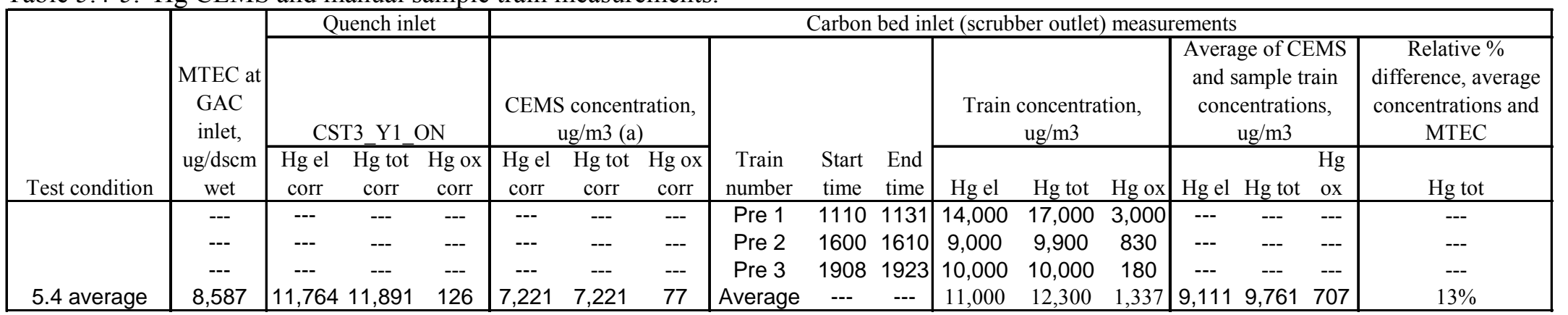

a. Calculated from the quench inlet concentrations assuming no total $\mathrm{Hg}$ scrubbing in the wet scrubber.

\begin{tabular}{|c|c|c|c|c|c|c|c|c|c|c|c|c|}
\hline \multirow[b]{3}{*}{ Test condition } & \multicolumn{12}{|c|}{ Carbon bed stage 3 outlet measurements } \\
\hline & \multicolumn{3}{|c|}{$\begin{array}{l}\text { CEMS concentration, } \\
\mathrm{ug} / \mathrm{m} 3\end{array}$} & \multirow[b]{2}{*}{$\begin{array}{c}\text { Train } \\
\text { number }\end{array}$} & \multirow[b]{2}{*}{$\begin{array}{l}\text { Start } \\
\text { time }\end{array}$} & \multirow[b]{2}{*}{$\begin{array}{l}\text { End } \\
\text { time }\end{array}$} & \multicolumn{3}{|c|}{$\begin{array}{c}\text { Train concentration, } \\
\mathrm{ug} / \mathrm{m} 3\end{array}$} & \multicolumn{3}{|c|}{$\begin{array}{c}\text { Average of CEMS } \\
\text { and sample train } \\
\text { concentrations, } \\
\mathrm{ug} / \mathrm{m} 3\end{array}$} \\
\hline & $\begin{array}{l}\mathrm{Hg} \text { el } \\
\text { corr }\end{array}$ & Hg tot & $\begin{array}{c}\text { Hg tot } \\
\text { corr }\end{array}$ & & & & $\mathrm{Hg}$ el & $\mathrm{Hg}$ tot & $\mathrm{Hg}$ ox & $\mathrm{Hg}$ el & $\mathrm{Hg}$ tot & $\begin{array}{l}\mathrm{Hg} \\
\text { ox }\end{array}$ \\
\hline & --- & --- & --- & Post 1 & 1040 & 1240 & 4 & 5 & 1 & --- & -- & --- \\
\hline & --- & --- & --- & Post 2 & 1250 & 1520 & 6 & 8 & 2 & --- & --- & --- \\
\hline & --- & --- & --- & Post 3 & 1626 & 1826 & 2 & 3 & 1 & --- & --- & --- \\
\hline 5.4 average & 20 & 0 & 9 & Average & --- & --- & 4 & 5 & 1 & 12 & 3 & 5 \\
\hline
\end{tabular}




\section{SUMMARY AND CONCLUSIONS}

About one million gallons of acidic, hazardous and radioactive, sodium-bearing waste (SBW) is stored in stainless steel tanks at the Idaho Nuclear Technology and Engineering Center (INTEC), which is a major operating facility of the Idaho National Engineering and Environmental Laboratory (INEEL). This mixed waste was produced during nuclear fuel reprocessing activities that was halted in the 1990s, and remains after cessation of fluidized bed calcination that has already converted raffinate waste (also from nuclear fuel reprocessing) and much of the SBW into a more safely stored solid calcine powder. Further treatment of the remaining SBW inventory is on hold pending a review and determination of the most appropriate treatment method. Steam reforming is a candidate technology being investigated for treatment of the SBW into a road ready waste form that can be shipped to the Waste Isolation Pilot Plant in New Mexico for interment.

Fluidized bed steam reforming technology, licensed to ThermoChem Waste Remediation, LLC (TWR) by Manufacturing Technology Conversion International (MTCI), was tested in two phases using an INEEL (Department of Energy) fluidized bed test system located at the Science Applications International Corporation (SAIC) Science and Technology Applications Research Center in Idaho Falls, Idaho. This first phase of tests showed that SBW could be successfully converted into an alkali carbonate powder without serious agglomeration, but the emphasis was on process viability and reliability rather than on production and optimization.

The MTCI steam reforming process provides a thermal and reactive environment to (a) evaporate the liquid SBW simulant feed and produce a dry, granular product and (b) destroy nitrates in the feed and $\mathrm{NO}_{\mathrm{x}}$ evolved from those nitrates. Organic reductants, when fed to the fluidized bed, produces the reducing environment through steam-reformed and pyrolysis products, including hydrogen, methane, and reactive hydrocarbon free-radicals that react with and destroy nitrates and $\mathrm{NO}_{\mathrm{x}}$.

Phase 2 tests were performed in October 2003 to evaluate the MTCI process under a wider range of conditions and using a more efficient reductant (isopropyl alcohol, also know as IPA). For Phase 2, the process feed rate, reductant stoichiometry, and process temperature were varied to identify and demonstrate how the process might be optimized to improve operation and product characteristics. Two test series were performed. The first series focused more on process chemistry, the second series more on process reliability and particle size control. The tests also demonstrated the performance of a MACTcompliant off-gas system.

\subsection{Emulation of the MTCI Technology}

The fluidized bed test system was designed and built in 2002 to provide a test bed for evaluating steam reforming for SBW treatment. The test system was designed to facilitate testing, with extensive process monitoring and controls, and electronic data collection and reporting features. Some specific features, such as the capability to add solid reductants, were included to emulate the MTCI technology, based on recommendations from TWR.

TWR participated in the Phase 2 tests to ensure that the tests represented the MTCI technology to the extent possible. During test planning stages, TWR provided recommendations for process chemistry modifications and reviewed test objectives. Under subcontract to the INEEL, TWR personnel observed the test series, provided consultation and recommendations during the tests, and produced an observation report for INEEL.

Before the Phase 2 tests, the test facility was modified to include representative components of a full off-gas system that would be required for a thermal process, such as steam reforming, to treat SBW 
and comply with the Hazardous Waste Combustor (HWC) Maximum Achievable Control Technology (MACT) standards.

The reformer bed was fluidized with carbon dioxide. A non-radioactive SBW simulant was fed through a water-cooled nozzle into the fluidized bed and atomized by carbon dioxide. The starting bed was dense alumina particles. A liquid organic reductant, IPA, was blended with the SBW simulant just before the feed nozzle. Solid reductant particles (polypropylene) were available to be fed through a separate access port, but they were not necessary to achieve adequate reformer performance. The IPA reductant produced the methane, hydrogen, and free-radicals needed to destroy $\mathrm{NO}_{\mathrm{x}}$. The test objectives included varying the amounts of reductant and process temperature to determine minimum levels that still provide adequate $\mathrm{NO}_{\mathrm{x}}$ destruction.

\subsection{Phase 2 Accomplishments, Conclusions, and Recommendations}

Table 2-1 summarizes the Phase 2 test objectives and accomplishments. All of the test objectives were accomplished except for controlling bed particle size distribution. Several areas were identified for additional test operation or technology development/demonstration. These areas are:

- $\quad$ Control of the carbonate bed particle size growth

- $\quad$ Better control of feed to control agglomerate formation caused by feed surges, including reconfiguring the feed system to be less prone to plugging by solids

- $\quad$ Fines recycled to encourage new particle growth

- Better demonstration or improved performance of feed system components

- $\quad$ Operation for longer times to demonstrate long-term performance.

\subsubsection{Fluidized Bed Test System and Modifications}

The primary components of the test system included the reformer vessel, product collection systems, feed systems, off-gas control system, and process logic controller (PLC) system. The test system covered a footprint of about $40 \times 40$ feet. Equipment and piping were fabricated from 300 -series stainless steel except for the reformer vessel, which was fabricated from Inconel $800 \mathrm{H}$. The system could be manually controlled or automatically controlled using a process logic controller (PLC) system with multiple human-machine interface (HMI) stations.

The main features of the fluidized bed vessel were the fluidized-bed section, freeboard (particle disengaging) section, and gas distributor through which the fluidizing gas enters the vessel. The bed and freeboard sections were externally heated with electrical resistance heaters for temperature control. The fluidized-bed section was 6 inches in diameter and 30 inches tall. The freeboard section was 12 inches in diameter and 60 inches high. Numerous ports in the bed and freeboard sections enabled access for input streams and process instrumentation.

Several modifications were made to the reformer vessel before the Phase 2 tests to improve operation and data quality. These modifications were (a) relocation of several thermocouples to reduce pressure port plugging, (b) installation of an active bed sample drain, (c) a redesigned gas distributor to optimize pressure drop and gas distribution while accommodating a bed drain, sample port, and instrumentation, and (d) incorporation of a water-cooled auger to feed solid reductant into the bottom of the reformer. 
Table 6-1. Phase 2 test objectives and accomplishments.

\begin{tabular}{|c|c|}
\hline Test objective & Accomplishment \\
\hline $\begin{array}{l}\text { 1. Determine suitable fluidized-bed } \\
\text { operating parameters for treating the } \\
\text { simulated WM-180 SBW supernate } \\
\text { and suspended solids that will: }\end{array}$ & $\begin{array}{l}\text { Each of the components of this test objective were accomplished, as } \\
\text { described below. }\end{array}$ \\
\hline $\begin{array}{l}\text { A. Achieve } 90 \% \text { destruction of } \mathrm{NO}_{\mathrm{x}} \\
\text { off-gas emissions relative to } \\
\text { nitrates in the feed }\end{array}$ & $\begin{array}{l}\mathrm{NO}_{\mathrm{x}} \text { destruction ranged from } 82 \% \text { to } 97 \% \text { for different test } \\
\text { conditions. } \mathrm{NO}_{\mathrm{x}} \text { destruction for several test conditions exceeded } \\
90 \% \text {. }\end{array}$ \\
\hline $\begin{array}{l}\text { b. Achieve an SBW processing rate } \\
\text { similar to or greater than previous } \\
\text { tests }(\geq 4 \mathrm{~L} / \mathrm{hr})\end{array}$ & $\begin{array}{l}\text { The SBW simulant feed rate exceeded } 4 \mathrm{~L} / \mathrm{hr} \text { during several test } \\
\text { conditions. }\end{array}$ \\
\hline $\begin{array}{l}\text { c. Maintain a stable bed with } \\
\text { minimal addition of bed seed } \\
\text { particles }\end{array}$ & $\begin{array}{l}\text { No bed seed particles were added during the tests. Control of the } \\
\text { carbonate bed particle size was not accomplished during the tests } \\
\text { using only the nozzle atomizing gas flow to induce attrition. } \\
\text { Additional tests are needed to develop and demonstrate the best of } \\
\text { several possible options for bed particle size control. Possible } \\
\text { options include adding separate jet attrition in the fluidized bed, } \\
\text { adding bed seed particles, recycling more of the fines, or removing, } \\
\text { attriting, and reusing bed product. }\end{array}$ \\
\hline $\begin{array}{l}\text { d. Reduce/minimize carryover of } \\
\text { unreacted carbon and } \\
\text { carbonaceous compounds in the } \\
\text { product }\end{array}$ & $\begin{array}{l}\text { The bed product had essentially no organic carbon residues. The } \\
\text { level of organic carbon in the cyclone and filter fines was under } 7 \\
\mathrm{wt}^{\mathrm{t}} \mathrm{o} \text {. }\end{array}$ \\
\hline $\begin{array}{l}\text { 2. Demonstrate Hazardous Waste } \\
\text { Combustor (HWC) Maximum } \\
\text { Achievable Control Technology } \\
\text { (MACT) compliance: }\end{array}$ & Compliance to the HWC MACT standards was demonstrated. \\
\hline $\begin{array}{l}\text { Determine the combustion } \\
\text { efficiency of the thermal oxidizer } \\
\text { and characterize the outlet gas } \\
\text { composition }\end{array}$ & $\begin{array}{l}\text { The thermal oxidizer outlet off-gas composition was measured and } \\
\text { showed sufficiently high efficiency to lower CO and THC } \\
\text { emissions to } 20 \% \text { or less of the MACT standard. }\end{array}$ \\
\hline $\begin{array}{l}\text { b. Determine control efficiencies for } \\
\mathrm{Hg} \text { and } \mathrm{Cl} \text { in the scrubber and } \\
\text { carbon bed }\end{array}$ & $\begin{array}{l}\text { Measured system removal efficiencies for } \mathrm{Hg} \text { ranged about } 99.8 \% \text {, } \\
\text { lowering the total } \mathrm{Hg} \text { levels at the stack to less than } 50 \% \text { of the } \\
\text { MACT standard. } \mathrm{HCl} \text { levels were essentially undetectable, ranging } \\
\text { under } 1 \% \text { of the MACT standard. Mass balances show that most of } \\
\text { the } \mathrm{Cl} \text { was retained in the solid products. }\end{array}$ \\
\hline $\begin{array}{l}\text { 3. Determine the fate of feed constituents } \\
\text { and additives, including the halides, } \\
\text { volatile heavy metals, cesium, etc. }\end{array}$ & $\begin{array}{l}\text { The fate of } \mathrm{NO}_{3} \text {, alkali metals, hazardous metals, radionuclide } \\
\text { surrogates, halides and other anions, and organic reductants was } \\
\text { rigorously determined. All feed constituents except Hg were } \\
\text { quantitatively retained in the total solids (bed product and filter } \\
\text { fines) during the test. }\end{array}$ \\
\hline $\begin{array}{l}\text { 4. Characterize solid product } \\
\text { composition, quantity, and handling } \\
\text { properties }\end{array}$ & $\begin{array}{l}\text { The solid products, quantity, and properties, including particle size, } \\
\text { composition, and density were measured and reported. }\end{array}$ \\
\hline
\end{tabular}


Product fines and process gases exited the freeboard section and passed through a heated, 5-inchdiameter cyclone separator to remove most of the particles in excess of $15 \mu \mathrm{m}$. The off-gas was subsequently filtered in a heated filter vessel containing seven 2.5-inch-diameter, 24-inch-long, sinteredmetal filters with a nominal pore size of $2 \mu \mathrm{m}$.

Cyclone and filter catch fines collected continuously in drums located below the cyclone and filter vessels. Sample spoons were incorporated in the tops of the drums, before the Phase 2 tests, to obtain real-time catch samples.

The liquid feed system included the 800-liter simulant hold/makeup tank, two 200-liter day-tanks, and a liquid reductant (IPA) feed system. All three tanks were equipped with variable speed agitators and a recirculation/transfer pump to ensure that the solutions were fully mixed and undissolved solids remained suspended and uniformly blended. The liquid feed system was modified before the Phase 2 tests to enable simultaneous metering of two separate liquid feeds, so that simulant and liquid reductant blend ratios could be easily varied, and to mimic how a full-scale treatment facility might be operated. The two feed streams were combined just before being atomized in the feed nozzle. The liquid feed nozzle was a water-cooled, gas-atomizing liquid spray nozzle.

Following recommendations from TWR, the solid reductant feed system was modified for better controllability and to reduce pressure fluctuations of the fluidized bed. A pneumatic injection system was replaced with a water-cooled auger to protect the solid reductant until it had entered the bed.

Just before the Phase 2 tests, the off-gas system was upgraded with new equipment to emulate a complete off-gas system capable of meeting air emission limits of the HWC MACT standards. The offgas system downstream of the heated filter included a natural gas-fired thermal oxidizer, a water-spray partial quench vessel, a venturi scrubber, a mist eliminator, an electric reheater, and a 3-stage carbon bed. An air eductor induced draft through the entire system, diluted the off-gas, and vented the air-off-gas blend to the SAIC STAR Center stack.

\subsubsection{Test Series Results and Conclusions}

Process conditions of the carbonate test series were designed to produce an alkali carbonate product. Several different test conditions were performed to provide operating time for process stabilization and bed building, determine maximum and optimum simulant feed rates, and to vary and optimize the reductant stoichiometry. All of the carbonate tests were conducted at nominal bed temperatures ranging from 583 to $610^{\circ} \mathrm{C}$. Test results and conclusions are summarized below:

The cumulative operating time exceeded 109 hours, during which time the total liquid feed rate reached $9.7 \mathrm{~kg} / \mathrm{hr}$, with an SBW feed rate maximum of $5.2 \mathrm{~kg} / \mathrm{hr}(4.1 \mathrm{~L} / \mathrm{hr})$.

Tests showed that the IPA is an effective liquid reductant and able to satisfactorily reduce $\mathrm{NO}_{\mathrm{x}}$ emissions without the use of a solid reductant additive.

Control of bed particle size growth was not achieved using nozzle atomizing gas flow to induce particle attrition. Particle size management systems/devices need to be employed during future testing, such as jet grinders, mills, fines recycle, etc. because the carbonate product is attrition resistant.

Operation while feeding a simulant that contained simulated tank heel solids was demonstrated.

The bed turned over about 1.2 times during the test, as feed solids were retained in the bed and starting bed particles grew in mass and size. About $90 \%$ of the solids in the feed partitioned to the bed 
product, and the remainder, about $10 \%$, partitioned to the cyclone and filter fines. Only $0.2 \%$ of the input mass was collected in the scrub water.

As the bed particles grew in size and mass, the particle density decreased from about $3.95 \mathrm{~g} / \mathrm{cc}$ (for the starting alumina bed media) to about $2.9 \mathrm{~g} / \mathrm{cc}$. The cyclone and filter fines were less dense than the bed product. The cyclone catch particle density was about $2.7 \mathrm{~g} / \mathrm{cc}$. The filter catch particle was about $1.0 \mathrm{~g} / \mathrm{cc}$. The sizes of individual filter fines particles ranged predominantly under one micron, but many of the particles were agglomerated into larger particles.

The concentrations of the primary simulant feed products $\left(\mathrm{CO}_{3}, \mathrm{~K}\right.$, and $\left.\mathrm{Na}\right)$ in the bed samples show a continuous trend of increasing amounts of simulant feed products. The amounts of these species in the bed product would continue to asymptotically approach the theoretically calculated concentrations for these species (up to $29 \mathrm{wt} \% \mathrm{CO}_{3}, 5.2 \mathrm{wt} \% \mathrm{~K}$, and $30 \mathrm{wt} \% \mathrm{Na}$ ). The amounts of these species measured in the bed product indicate that between $40-70 \%$ of the bed material was product from the simulant feed rather than starting bed alumina.

The wet-basis steam reformer off-gas contained about 40 vol $\% \mathrm{H}_{2} \mathrm{O} . \mathrm{CO}_{2}$ levels averaged over $50 \%, \mathrm{H}_{2}$ averaged under $2 \%$ and $\mathrm{CO}$ averaged under $0.5 \% . \mathrm{CH}_{4}$ ranged under $1 \%$, and $\mathrm{NO}$ averaged about 1,500 ppm.

The steam reformer $\mathrm{NO}_{\mathrm{x}}$ destruction (based on the steam reformer outlet $\mathrm{NO}$ measurements) averaged about $92 \%$ for the demonstration tests. Feed nitrate destruction averaged $99.8 \% . \mathrm{NO}_{\mathrm{x}}$ destruction for the entire steam reforming test system, using the $\mathrm{NO}$ and $\mathrm{NO}_{\mathrm{x}}$ measurements at the outlet of the thermal oxidizer, averaged $92 \%$.

Most of the feed constituents partitioned to the bed product. Even those normally considered volatile in thermal systems $(\mathrm{Cl}, \mathrm{F}, \mathrm{Cs}, \mathrm{Pb}, \mathrm{Re}$, and $\mathrm{Zn})$ partitioned significantly to the bed product. Even though these species tended to partition to the filter fines, they were nearly all quantitatively captured in the total solid mass, which includes both the bed product and filter fines.

Mercury partitioned quantitatively to the off-gas. Consistent with expectations, essentially all of the off-gas $\mathrm{Hg}$ was measured in the form of elemental $\mathrm{Hg}$ downstream of the thermal oxidizer. The total mercury was efficiently controlled by the carbon bed (averaged over $99.8 \%$ removal efficiency).

The bed product had essentially no organic carbon residues and the residues in the cyclone and filter catches was under $7 \%$. The mass reduction from feed treatment was $88 \%$. 


\section{REFERENCES}

Barnes, C. M., 2001, Feed Composition for the Sodium-Bearing Waste Treatment Process, INEEL/EXT2000-01378, Rev. 1, July.

EPA 2002, "Determination of Sulfur Dioxide Emissions, from Stationary Sources (Instrumental Analysis Procedure)," 40 CFR 60, Appendix A, Method 6C.

INEEL, 2003, SRS Tank 48 Steam Reforming Demonstration Test Plan, final draft internal INEEL report, July.

Magrini-Bair, Kimberly, Stefan Czernik, et al., "Fluidizable Catalyts for Producing Hydrogen by Steam Reforming Biomass Pyrolysis Liquids," NREL/CP-610-32405, Proceedings of the 2002 U.S. DOE Hydrogen Program Review.

Marshall, D.W. and N. R. Soelberg, 2003a, TWR Bench-Scale Steam Reforming Demonstration, INEEL/EXT-03-00436, May.

Marshall, D. W., N. R. Soelberg, and K.M. Shaber, 2003b, THOR ${ }^{\text {sm }}$ Bench-scale Steam Reforming Demonstration, INEEL/EXT-03-00437, May.

Ogden, Joan M., 2002, “Review of Small Stationary Reformers for Hydrogen Production,” IEA/H2/TR$02 / 002$.

Rowley, Debbie, 2003, personal communication to Nick Soelberg, 16 July.

SAIC 2003, “Steam Reformer Operating Instructions,” SAIC-SR-OI-01, Rev. 2, January.

St. Michel, Curtis, 2003, System Description, Fluidized Bed Steam Reformer Data Acquisition and Controls, internal INEEL report, December.

Soelberg, Nick, Doug Marshall, Steve Bates, and Duane Siemer, 2003a, SRS Tank 48H Waste Steam Reforming Proof-of-Concept Test Results, INEEL/EXT-03-01118, September 15.

Soelberg, Nick, 2003b, Off-gas Mercury Control for the Idaho Tank Farm Project - Calcination with MACT Upgrade SBW Treatment Alternative, INEEL EDF-3292, Revision 0, February.

Soelberg, Nick, et al., 2004, THOR Process Optimization Tests for Sodium-Bearing Waste Treatment, INEEL/EXT-04-01493.

Taylor, Dean, 2004, HSC Calculations for Steam Reforming Optimization Tests, unpublished INEEL report, January. 
Appendix A

\section{Operating Conditions}


Table A-1. Process mass flow rates and conditions for the TWR test series week 1.

\begin{tabular}{|c|c|c|c|c|c|c|c|c|c|c|c|c|c|c|c|c|c|c|c|c|}
\hline & $\begin{array}{c}\text { Corrected } \\
\text { off-gas } \\
\text { flowrate, } \\
\mathrm{kg} / \mathrm{hr}\end{array}$ & $\begin{array}{c}\text { Simulant } \\
\text { flow to } \\
\text { fluidized } \\
\text { bed } \\
(\mathrm{kg} / \mathrm{hr})\end{array}$ & $\begin{array}{c}\text { Fluidizing } \\
\mathrm{CO}_{2} \text { flow } \\
\text { (kg/hr) }\end{array}$ & $\begin{array}{c}\text { Total } \\
\mathrm{CO}_{2} \text { flow } \\
(\mathrm{kg} / \mathrm{hr})\end{array}$ & $\begin{array}{c}\text { Total } \\
\mathrm{H}_{2} \mathrm{O} \\
\text { input, } \\
\mathrm{kg} / \mathrm{hr}\end{array}$ & $\begin{array}{c}\text { Total } \\
\text { mass } \\
\text { input, } \\
\mathrm{kg} / \mathrm{hr}\end{array}$ & $\begin{array}{c}\text { Mass } \\
\text { out/ } \\
\text { mass in }\end{array}$ & $\mid \begin{array}{c}\text { Calculated } \\
\mathrm{H}_{2} \mathrm{O} \text { At } \\
\text { CEM1, \% }\end{array}$ & $\begin{array}{l}\text { Calc. } \\
\text { NAR }\end{array}$ & $\begin{array}{c}\text { SR bed } \\
\text { temp } \\
\text { control } \\
\text { point at } \\
\mathrm{T} 4,{ }^{\circ} \mathrm{C}\end{array}$ & $\begin{array}{c}\text { SR wall } \\
\text { temp } \\
\text { control } \\
\text { point at } \\
\mathrm{T} 19,{ }^{\circ} \mathrm{C}\end{array}$ & $\begin{array}{c}\text { Fluidizing } \\
\text { gas temp at } \\
\text { H-1 super } \\
\text { heater } \\
\text { discharge }\end{array}$ & $\begin{array}{l}\text { Oxidizer } \\
\text { temp }{ }^{\circ} \mathrm{C}\end{array}$ & $\begin{array}{c}\text { Oxidizer } \\
\text { outlet } \\
\text { temp, }{ }^{\circ} \mathrm{C}\end{array}$ & $\begin{array}{c}\text { Oxidizer } \\
\text { fuel }(\mathrm{NG}) \\
\text { flow, } \mathrm{kg} / \mathrm{hr}\end{array}$ & $\begin{array}{c}\text { Oxidizer } \\
\text { secondary } \\
\text { air flow, } \\
\mathrm{kg} / \mathrm{hr}\end{array}$ & $\begin{array}{c}\text { Oxidizer } \\
\text { burner } \\
\text { air flow, } \\
\mathrm{kg} / \mathrm{hr}\end{array}$ & $\begin{array}{c}\text { Simulant } \\
\text { feed } \\
\text { density } \\
(\mathrm{gm} / \mathrm{cc})\end{array}$ & \begin{tabular}{|c} 
IPA \\
Feed \\
Density \\
(gm/cc) \\
\end{tabular} & $\begin{array}{c}\text { IPA Feed } \\
\text { Mass Flow } \\
\text { to } \\
\text { Fluidized } \\
\text { Bed }(\mathrm{kg} / \mathrm{hr})\end{array}$ \\
\hline Test & & $\begin{array}{c}\text { SR1_F1A } \\
\text { VAL }\end{array}$ & H1 F PV & $\frac{\mathrm{V} 1 \_\mathrm{F} 1 \_\mathrm{V}}{\mathrm{AL}}$ & & $\begin{array}{c}\text { V1_F1 } \\
\text { VAL }\end{array}$ & & & NAR & $\begin{array}{c}\text { SR1_T4 } \\
\text { VAL }\end{array}$ & $\begin{array}{c}\text { SR1_T9 } \\
\text { VAL }\end{array}$ & $\underset{\mathrm{L}}{\mathrm{H} 2 \text { T_VA }}$ & $\begin{array}{c}\text { B1_T1_- } \\
\text { VAL }\end{array}$ & $\begin{array}{c}\text { B1_T2_- } \\
\text { VAL }\end{array}$ & B1_F1_VA & 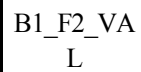 & $\begin{array}{c}\text { B1_F3_- } \\
\text { VAL }\end{array}$ & $\left|\begin{array}{c}\text { SR1_D1A } \\
\text { VAL }\end{array}\right|$ & $\begin{array}{l}\text { SR1_D1 } \\
\text { C VAL }\end{array}$ & $\begin{array}{l}\text { SR1_F1C_ } \\
\text { VAL }\end{array}$ \\
\hline 1.0 & 150 & 2.0 & 14.0 & 22.0 & 4.92 & 154 & 0.970 & 29.70 & 373 & 580 & 628 & 33.7 & 1,000 & 924 & 2.9 & 58.8 & 29.0 & 1.18 & 1.18 & 2.92 \\
\hline 1.1 & 148 & 2.5 & 14.0 & 21.8 & 4.56 & 152 & 0.972 & 29.15 & 377 & 580 & 626 & 34.5 & 1,000 & 921 & 3.1 & 62.5 & 24.2 & 1.24 & 1.24 & 2.39 \\
\hline 2.1 & 147 & 2.5 & 13.6 & 21.8 & 4.53 & 153 & 0.962 & 29.10 & 397 & 593 & 640 & 34.7 & 1,000 & 921 & 3.2 & 63.3 & 23.6 & 1.25 & 1.25 & 2.37 \\
\hline 2.2 & 144 & 2.5 & 13.3 & 21.4 & 4.55 & 152 & 0.947 & 29.47 & 392 & 606 & 652 & 32.7 & 1,000 & 920 & 3.1 & 62.9 & 24.1 & 1.24 & 1.24 & 2.38 \\
\hline 3.1 & 141 & 3.0 & 13.2 & 21.9 & 4.49 & 154 & 0.919 & 29.48 & 398 & 610 & 657 & 29.3 & 1,000 & 919 & 3.5 & 69.3 & 18.5 & 1.20 & 1.20 & 1.97 \\
\hline 3.2 & 144 & 3.4 & 13.2 & 21.8 & 4.13 & 153 & 0.942 & 28.39 & 399 & 611 & 656 & 26.9 & 1,000 & 918 & 3.8 & 76.0 & 12.1 & 1.20 & 1.20 & 1.47 \\
\hline 3.3 & 145 & 2.1 & 13.2 & 21.5 & 4.67 & 152 & 0.959 & 29.40 & 377 & 611 & 654 & 31.2 & 1,000 & 918 & 3.0 & 59.8 & 27.3 & 1.22 & 1.22 & 2.69 \\
\hline 3.4 & 141 & 2.0 & 13.5 & 22.2 & 4.81 & 153 & 0.923 & 29.23 & 376 & 597 & 638 & 31.6 & 1,000 & 917 & 2.8 & 56.2 & 30.5 & 1.24 & 1.24 & 2.88 \\
\hline 3.5 & 142 & 2.1 & 13.9 & 21.9 & 4.76 & 151 & $\begin{array}{l}0.929 \\
\end{array}$ & 29.38 & 323 & 583 & 622 & 31.9 & 1,000 & 917 & 2.8 & $\begin{array}{l}56.8 \\
\end{array}$ & 29.1 & 1.23 & 1.23 & 2.76 \\
\hline 3.6 & 143 & 2.6 & 13.9 & 22.2 & 4.69 & 151 & 0.945 & 29.43 & 340 & 582 & 625 & 32.4 & 1,000 & 916 & 3.1 & 61.6 & 24.2 & 1.21 & 1.21 & 2.40 \\
\hline \multicolumn{21}{|l|}{ Shutdown } \\
\hline 1.2 & 154 & 3.9 & 15.8 & 26.5 & 7.07 & 163 & 0.945 & 33.20 & 402 & 599 & 664 & 29.2 & 1,000 & 919 & 2.4 & 56.1 & 29.3 & 1.21 & 1.21 & 3.64 \\
\hline 1.3 & 172 & 5.0 & 15.6 & 27.8 & 9.06 & 165 & 1.041 & 36.72 & 397 & 597 & 677 & 33.5 & 1,000 & 919 & 1.8 & 42.3 & 39.3 & 1.24 & 1.24 & 4.74 \\
\hline 1.4 & 171 & 1.7 & 17.6 & 27.8 & 4.33 & 167 & 1.026 & 18.27 & 397 & 494 & 533 & 31.5 & 1,000 & 920 & 3.3 & 72.9 & 19.5 & 1.16 & 1.16 & 2.57 \\
\hline Average & 155 & 3.4 & 15.0 & 24.9 & 6.25 & 159 & 0.977 & 31.07 & 393 & 590 & 648 & 31.2 & 1,000 & 919 & 2.7 & 58.0 & 27.9 & 1.19 & 1.19 & 2.92 \\
\hline Std Dev & 15 & 1.4 & 1.6 & 3.2 & 2.40 & 12 & 0.060 & 7.41 & 24 & 51 & 64 & 2.7 & 2 & 3 & 0.8 & 14.9 & 11.8 & 0.09 & 0.09 & 1.56 \\
\hline
\end{tabular}


Table A-2. Process volume flow rates for the TWR test series week 1.

\begin{tabular}{|c|c|c|c|c|c|c|c|c|c|c|c|c|c|c|c|c|c|}
\hline & $\begin{array}{c}\text { Off-gas } \\
\text { flowrate } \\
\text { at GAC } \\
\text { bed, } \\
\mathrm{kg} / \mathrm{hr}\end{array}$ & $\begin{array}{c}\text { Off-gas } \\
\text { flowrate at } \\
\text { GAC bed, } \\
\text { wscfm } \\
\end{array}$ & $\begin{array}{c}\text { Off-gas } \\
\text { flowrate at } \\
\text { filter } \\
\text { outlet, } \\
\text { wscfm } \\
\end{array}$ & $\begin{array}{c}\text { Simulant } \\
\text { Feedrate, } \\
\text { L/hr }\end{array}$ & $\begin{array}{c}\mathrm{H}_{2} \mathrm{O} \text { from } \\
\text { simulant, } \\
\mathrm{kg} / \mathrm{hr}\end{array}$ & $\begin{array}{l}\mathrm{H}_{2} \mathrm{O} \\
\text { from } \\
\mathrm{IPA}, \\
\mathrm{kg} / \mathrm{hr}\end{array}$ & $\begin{array}{l}\mathrm{CO}_{2} \\
\text { from } \\
\mathrm{IPA}, \\
\mathrm{kg} / \mathrm{hr}\end{array}$ & $\begin{array}{c}\text { Fluidizing } \\
\text { Gas } \\
\text { flowrate, } \\
\mathrm{kg} / \mathrm{hr} \\
\end{array}$ & $\begin{array}{l}\text { Total } \\
\mathrm{H}_{2} \mathrm{O}, \\
\mathrm{kg} / \mathrm{hr}\end{array}$ & $\begin{array}{l}\text { Total } \\
\mathrm{H}_{2} \mathrm{O} \\
\mathrm{scfm} \\
\end{array}$ & \begin{tabular}{|c|} 
Total $\mathrm{CO}_{2}$ \\
at system \\
inlet, \\
$\mathrm{kg} / \mathrm{hr}$
\end{tabular} & $\begin{array}{l}\text { Total } \\
\mathrm{CO}_{2}, \\
\mathrm{scfm} \\
\end{array}$ & $\begin{array}{l}\text { Total } \\
\text { mass } \\
\text { input, } \\
\mathrm{kg} / \mathrm{hr}\end{array}$ & \begin{tabular}{|c|} 
Off-gas \\
mass \\
out/ \\
mass in
\end{tabular} & $\begin{array}{c}\text { Scrubber } \\
\text { outlet gas } \\
\text { pressure, } \\
\text { psia }\end{array}$ & $\begin{array}{c}\text { Scrubber } \\
\text { outlet gas } \\
\text { temp, C } \\
\end{array}$ & $\begin{array}{c}\mathrm{H}_{2} \mathrm{O} \text { at } \\
\text { the GAC } \\
\text { bed from } \\
\text { scrub T, } \\
\% \\
\end{array}$ \\
\hline Test & & & \begin{tabular}{|c} 
OXI_F1_- \\
SCFM
\end{tabular} & $\begin{array}{c}\text { SR1_F1A } \\
\text { VFR } \\
\end{array}$ & & \begin{tabular}{|c|} 
IPA_T \\
O_H2 \\
O_KG \\
H \\
\end{tabular} & $\begin{array}{r}\text { IPA_T } \\
\text { O_CO2 } \\
\text { KGH } \\
\end{array}$ & H1 F2 PV & $\begin{array}{c}\mathrm{H} 2 \mathrm{O} \_\mathrm{T} \\
\mathrm{OT} \text {-M } \\
\text { ASS_I } \\
\mathrm{N} \\
\end{array}$ & & $\begin{array}{l}\text { V1_F_- } \\
\text { VAL }\end{array}$ & & & & T7 P VAL & $\begin{array}{c}\text { T7_T2 } \\
\text { VAL } \\
\end{array}$ & \\
\hline 1.0 & 150 & 60 & 11.5 & 1.68 & 1.41 & 3.50 & 6.4 & 14.0 & 6.2 & 4.86 & 22.0 & 9.12 & 154 & 0.97 & 10.3 & 68 & 38.9 \\
\hline 1.1 & 148 & 59 & 11.6 & 2.01 & 1.69 & 2.87 & 5.3 & 14.0 & 5.9 & 4.59 & 21.9 & 8.70 & 152 & 0.97 & 10.3 & 68 & 39.6 \\
\hline 2.1 & 147 & 58 & 11.7 & 2.01 & 1.69 & 2.84 & 5.2 & 13.6 & 5.8 & 4.57 & 21.8 & 8.67 & 153 & 0.96 & 10.1 & 68 & 40.0 \\
\hline 2.2 & 144 & 60 & 12.3 & 2.01 & 1.69 & 2.86 & 5.2 & 13.3 & 5.9 & 4.59 & 21.4 & 8.54 & 152 & 0.95 & 10.2 & 68 & 40.1 \\
\hline 3.1 & 141 & 57 & 13.1 & 2.53 & 2.13 & 2.33 & 4.3 & 13.2 & 5.9 & 4.60 & 21.9 & 8.39 & 154 & 0.92 & 10.2 & 69 & 40.8 \\
\hline 3.2 & 144 & 60 & 12.5 & 2.86 & 2.40 & 1.78 & 3.3 & 13.2 & 5.7 & 4.44 & 21.8 & 8.05 & 152 & 0.94 & 10.2 & 69 & 41.5 \\
\hline 3.3 & 145 & 65 & 13.0 & 1.72 & 1.44 & 3.23 & 5.9 & 13.2 & 5.9 & 4.65 & 21.5 & 8.80 & 152 & 0.96 & 10.3 & 69 & 42.0 \\
\hline 3.4 & 141 & 65 & 13.3 & 1.62 & 1.36 & 3.45 & 6.3 & 13.5 & 6.1 & 4.75 & 22.2 & 9.14 & 153 & 0.92 & 10.3 & 69 & 40.5 \\
\hline 3.5 & 142 & 65 & 13.1 & 1.73 & 1.45 & 3.31 & 6.1 & 13.9 & 6.0 & 4.72 & 21.9 & 8.98 & 151 & 0.93 & 10.3 & 68 & 40.5 \\
\hline 3.6 & 143 & 65 & 12.8 & 2.16 & 1.81 & 2.88 & 5.3 & 13.9 & 6.0 & 4.72 & 22.2 & 8.81 & 151 & 0.95 & 10.3 & 69 & 40.8 \\
\hline Shutdown & & & & & & & & & & & & & & & & & \\
\hline 1.2 & 154 & 63 & 17.4 & 3.25 & 2.73 & 4.47 & 8.2 & 15.8 & 8.7 & 6.84 & 26.4 & 11.10 & 163 & 0.94 & 10.0 & 67 & 39.9 \\
\hline 1.3 & 172 & 76 & 20.5 & 4.01 & 3.37 & 5.68 & 10.4 & 15.6 & 10.7 & 8.39 & 27.8 & 12.26 & 166 & 1.03 & 10.1 & 68 & 40.1 \\
\hline 1.4 & 171 & 70 & 16.8 & 3.48 & 1.78 & 4.27 & 7.8 & 17.5 & 7.3 & 5.75 & 28.3 & 11.59 & 167 & 1.03 & 10.2 & 68 & 38.9 \\
\hline Overal average & 156 & 66 & 16.1 & 3.01 & 2.46 & 4.03 & 7.4 & 14.9 & 8.0 & 6.24 & 25.0 & 10.38 & 160 & 0.97 & 10.1 & 68 & 40.2 \\
\hline Std Dev & 13 & 7 & 3.5 & 0.86 & 0.82 & 1.44 & 2.6 & 1.5 & 2.3 & 1.81 & 2.9 & 1.67 & 9 & 0.05 & 0.1 & 1 & 0.9 \\
\hline & & & & & & & & & & & & & & \multicolumn{4}{|c|}{ File:THOR Week2 CEM-MB.xls/process vol rates } \\
\hline
\end{tabular}


Table A-3. Process mass flow rates and conditions for TWR test series week 2 .

\begin{tabular}{|c|c|c|c|c|c|c|c|c|c|c|c|c|c|c|c|c|c|c|c|c|}
\hline Test & $\begin{array}{c}\text { Corrected } \\
\text { off-gas } \\
\text { flowrate, } \\
\mathrm{kg} / \mathrm{hr}\end{array}$ & $\begin{array}{c}\text { Simulant } \\
\text { flow to } \\
\text { fluidized } \\
\text { bed } \\
(\mathrm{kg} / \mathrm{hr})\end{array}$ & $\begin{array}{c}\text { Fluidizing } \\
\mathrm{CO}_{2} \text { flow } \\
(\mathrm{kg} / \mathrm{hr})\end{array}$ & $\begin{array}{c}\text { Total } \\
\mathrm{CO}_{2} \\
\text { flow } \\
(\mathrm{kg} / \mathrm{hr})\end{array}$ & $\begin{array}{l}\text { Total } \\
\mathrm{H}_{2} \mathrm{O} \\
\text { input, } \\
\mathrm{kg} / \mathrm{hr}\end{array}$ & \begin{tabular}{|c|} 
Total \\
mass \\
input, \\
$\mathrm{kg} / \mathrm{hr}$
\end{tabular} & $\begin{array}{c}\text { Mass } \\
\text { out/ } \\
\text { mass in }\end{array}$ & $\begin{array}{c}\mathrm{H} 2 \mathrm{O} \text { At } \\
\text { CEM1, } \\
\%\end{array}$ & $\begin{array}{l}\text { Calc. } \\
\text { NAR }\end{array}$ & $\begin{array}{c}\text { SR bed } \\
\text { temp } \\
\text { control } \\
\text { point at } \\
\mathrm{T} 4,{ }^{\circ} \mathrm{C}\end{array}$ & $\begin{array}{c}\text { SR wall } \\
\text { temp } \\
\text { control } \\
\text { point at } \\
\text { T19, }{ }^{\circ} \mathrm{C}\end{array}$ & $\begin{array}{c}\text { Fluidizing } \\
\text { gas temp at } \\
\text { H-1 super } \\
\text { heater } \\
\text { discharge }\end{array}$ & $\begin{array}{l}\text { Oxidizer } \\
\text { temp }{ }^{\circ} \mathrm{C}\end{array}$ & $\begin{array}{c}\text { Oxidizer } \\
\text { outlet } \\
\text { temp, }{ }^{\circ} \mathrm{C}\end{array}$ & $\begin{array}{l}\text { Oxidizer } \\
\text { fuel } \\
(\mathrm{NG}) \\
\text { flow, } \\
\mathrm{kg} / \mathrm{hr}\end{array}$ & \begin{tabular}{|c} 
Oxidizer \\
secondary \\
air flow, \\
$\mathrm{kg} / \mathrm{hr}$
\end{tabular} & $\begin{array}{c}\text { Oxidizer } \\
\text { burner } \\
\text { air flow, } \\
\mathrm{kg} / \mathrm{hr}\end{array}$ & $\begin{array}{c}\text { Simulant } \\
\text { Feed } \\
\text { Density } \\
(\mathrm{gm} / \mathrm{cc})\end{array}$ & $\begin{array}{c}\begin{array}{c}\text { IPA Feed } \\
\text { Density } \\
(\mathrm{gm} / \mathrm{cc})\end{array}\end{array}$ & \begin{tabular}{|c} 
IPA Feed \\
Mass Flow \\
to \\
Fluidized \\
Bed $(\mathrm{kg} / \mathrm{hr})$
\end{tabular} \\
\hline & & \begin{tabular}{|c|} 
SR1_F1A \\
VAL
\end{tabular} & $\begin{array}{c}\text { H1_F2_P } \\
\text { V }\end{array}$ & $\begin{array}{c}\text { V1_F1_ } \\
\text { VAL }\end{array}$ & & calc & & & NAR & $\begin{array}{c}\text { SR1_T4_- } \\
\text { VAL }\end{array}$ & $\begin{array}{c}\text { SR1_T9 } \\
\text { VAL }\end{array}$ & ${ }_{\text {H2_T_VA }}^{\text {L }}$ & $\begin{array}{c}\text { B1_T1_ } \\
\text { VAL }\end{array}$ & $\begin{array}{c}\text { B1_T2_- } \\
\text { VAL }\end{array}$ & $\begin{array}{c}\text { B1_F1_- } \\
\text { VAL }\end{array}$ & $\begin{array}{c}\text { B1_F2_VA } \\
\text { L }\end{array}$ & $\begin{array}{c}\text { B1_F3_- } \\
\text { VAL }\end{array}$ & $\begin{array}{c}\text { SR1_D1A } \\
\text { VAL }\end{array}$ & $\begin{array}{l}\text { SR1_D1C } \\
\text { VAL }\end{array}$ & $\begin{array}{l}\text { SR1_F1C_ } \\
\text { VAL }\end{array}$ \\
\hline 5.1 & 177 & 4.50 & 6.13 & 19.3 & 7.69 & 167 & 1.077 & 41.5 & 546 & 587 & 654 & 32.7 & 1,000 & 915 & 2.52 & 58.2 & 36.7 & 1.25 & 0.81 & 3.89 \\
\hline 5.2 & 145 & 4.50 & 6.18 & 17.4 & 7.26 & 167 & 0.867 & 42.7 & 467 & 584 & 656 & 33.3 & 1,000 & 917 & 2.76 & 69.0 & 29.2 & 1.25 & 0.81 & 3.52 \\
\hline 5.3 & 150 & 4.51 & 5.99 & 16.0 & 6.45 & 161 & 0.927 & 43.0 & 399 & 599 & 675 & 34.8 & 1,000 & 915 & 3.17 & 79.3 & 17.8 & 1.24 & 0.80 & 2.84 \\
\hline \multicolumn{21}{|l|}{$\begin{array}{l}\text { Shut- } \\
\text { down }\end{array}$} \\
\hline 5.3 & 174 & 4.51 & 5.58 & 16.5 & 6.21 & 163 & 1.061 & 42.0 & 498 & 603 & 659 & 29.9 & 1,000 & 913 & 3.35 & 67.0 & 31.4 & 1.21 & 0.79 & 2.55 \\
\hline \multicolumn{21}{|l|}{$\begin{array}{c}\text { Nozzle } \\
\text { Plug }\end{array}$} \\
\hline 5.3 & --- & 4.49 & 5.95 & 16.6 & 6.04 & 159 & --- & 41.3 & 497 & 603 & 637 & 24.0 & 1,001 & 911 & 3.32 & 65.1 & 31.6 & 1.22 & 0.79 & 2.43 \\
\hline \multicolumn{21}{|l|}{$\begin{array}{c}\text { Nozzle } \\
\text { Plug }\end{array}$} \\
\hline 5.3 & --- & 5.28 & 5.97 & 18.7 & 7.39 & 165 & 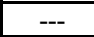 & 43.0 & 537 & 601 & 647 & 25.7 & 1,000 & 912 & 2.83 & 61.6 & 34.3 & 1.20 & 0.79 & 3.06 \\
\hline $\begin{array}{c}5.3 \\
\text { average }\end{array}$ & -- & 5.34 & 5.97 & 18.8 & 7.46 & 165 & --- & 43.1 & 539 & 601 & 648 & 25.8 & 1,000 & 912 & 2.80 & 61.5 & 34.4 & 1.20 & 0.79 & 3.08 \\
\hline 5.4 & 149 & 5.40 & 5.97 & 18.4 & 8.15 & 172 & 0.871 & 44.2 & 458 & 601 & 653 & 24.2 & 1,000 & 913 & 2.69 & 67.1 & 32.8 & 1.22 & 0.79 & 3.70 \\
\hline \multicolumn{21}{|l|}{$\begin{array}{c}\text { Nozzle } \\
\text { Plug }\end{array}$} \\
\hline 5.4 & 149 & 5.41 & 5.97 & 18.4 & 8.17 & 171 & 0.873 & 44.2 & 456 & 601 & 653 & 24.2 & 1,000 & 913 & 2.66 & 66.6 & 33.3 & 1.22 & 0.79 & 3.70 \\
\hline \multicolumn{21}{|l|}{$\begin{array}{c}\text { Nozzle } \\
\text { Plug }\end{array}$} \\
\hline 5.4 & 150 & 5.23 & 6.23 & 18.2 & 7.89 & 166 & 0.885 & 43.6 & 441 & 600 & 650 & 26.7 & 994 & 905 & 2.74 & 68.5 & 28.8 & 1.25 & 0.80 & 3.54 \\
\hline $\begin{array}{c}5.4 \\
\text { average }\end{array}$ & 150 & 5.25 & 6.21 & 18.2 & 7.91 & 167 & 0.884 & 43.7 & 442 & 600 & 650 & 26.5 & 994 & 906 & 2.74 & 68.4 & 29.1 & 1.25 & 0.80 & 3.55 \\
\hline Average & 152 & 4.91 & 6.00 & 17.5 & 7.20 & 165 & 0.907 & 43.0 & 462 & 600 & 655 & 28.7 & 997 & 910 & 2.95 & 68.6 & 28.9 & 1.23 & 0.80 & 3.17 \\
\hline Std Dev & 6.3 & 0.7 & 0.50 & 1.2 & 1.04 & 16 & 0.0 & 2.8 & \begin{tabular}{|l|}
49.9 \\
\end{tabular} & 8.8 & 17.5 & 2.1 & 25 & 24.8 & 0.4 & 7.0 & 7.1 & 0.06 & 0.04 & 0.78 \\
\hline & & & & & & & & & & & & & & & & FY04 We & CEMS-N & CEMS-MB & & \\
\hline
\end{tabular}


Table A-4. Process volume flow rates for TWR test series week 2.

\begin{tabular}{|c|c|c|c|c|c|c|c|c|c|c|c|c|c|c|c|c|c|}
\hline \multirow[t]{2}{*}{ Test } & $\begin{array}{c}\text { Off-gas } \\
\text { flow rate at } \\
\text { the GAC } \\
\text { bed, } \mathrm{kg} / \mathrm{hr}\end{array}$ & $\begin{array}{c}\text { Off-gas } \\
\text { flow rate at } \\
\text { the GAC } \\
\text { bed, wscfm }\end{array}$ & $\begin{array}{c}\text { Off-Gas } \\
\text { Flow to } \\
\text { Oxidizer } \\
\text { Inlet, scfm }\end{array}$ & $\begin{array}{c}\text { Simulant } \\
\text { feedrate, } \\
\mathrm{kg} / \mathrm{hr}\end{array}$ & $\begin{array}{c}\mathrm{H}_{2} \mathrm{O} \text { from } \\
\text { simulant, } \\
\mathrm{kg} / \mathrm{hr}\end{array}$ & $\begin{array}{c}\mathrm{H}_{2} \mathrm{O} \text { from } \\
\text { IPA } \\
(\mathrm{kg} / \mathrm{hr})\end{array}$ & $\begin{array}{c}\mathrm{CO}_{2} \\
\text { from } \\
\mathrm{IPA} \\
(\mathrm{kg} / \mathrm{hr})\end{array}$ & $\begin{array}{l}\text { Total } \\
\mathrm{H}_{2} \mathrm{O}, \\
\text { scfm } \\
\end{array}$ & $\begin{array}{c}\text { Total CO2 } \\
\text { purge } \\
\text { flowrate, } \\
\mathrm{kg} / \mathrm{hr}\end{array}$ & $\begin{array}{c}\text { Total CO2 } \\
\text { purge } \\
\text { flowrate, } \\
\text { scfm }\end{array}$ & $\begin{array}{l}\text { Total } \\
\mathrm{CO}_{2}, \\
\text { scfm } \\
\end{array}$ & $\begin{array}{l}\text { Total } \\
\text { mass } \\
\text { input, } \\
\mathrm{kg} / \mathrm{hr}\end{array}$ & $\begin{array}{c}\text { Mass } \\
\text { out/ } \\
\text { mass in }\end{array}$ & $\begin{array}{c}\text { Scrubber } \\
\text { outlet gas } \\
\text { pressure, } \\
\text { psia }\end{array}$ & $\begin{array}{c}\text { Scrubber } \\
\text { outlet gas } \\
\text { temp, C }\end{array}$ & \begin{tabular}{|c|}
$\mathrm{H} 2 \mathrm{O}$, \\
wet $\mathrm{N} 2$ \\
diluted \\
from \\
scrub $\mathrm{T}$, \\
$\%$ \\
\end{tabular} & $\begin{array}{c}\mathrm{H} 2 \mathrm{O}, \text { wet } \\
\mathrm{N} 2 \text { diluted } \\
\text { from } \mathrm{H} 2 \mathrm{O} \\
\text { in, } \%\end{array}$ \\
\hline & & & & $\begin{array}{c}\begin{array}{c}\text { SR1_F1A } \\
\text { VFR }\end{array} \\
\end{array}$ & & $\begin{array}{c}\mathrm{IPA} \mathrm{HO}_{-} \\
\mathrm{H} 2 \mathrm{O}_{-} \mathrm{KG}\end{array}$ & $\begin{array}{c}\text { IPA_TO } \\
\mathrm{CO}^{2} \\
\mathrm{KGH} \\
\end{array}$ & & $\begin{array}{l}\text { V1_F- } \\
\text { VAL }\end{array}$ & & & & & $\begin{array}{l}\text { T7_P- } \\
\text { VAL }\end{array}$ & $\begin{array}{c}\text { T7_T2 } \\
\text { VAL } \\
\end{array}$ & & \\
\hline 5.1 & 177 & 79.6 & 14.5 & 3.60 & 3.03 & 4.66 & 8.54 & 6.03 & 19.3 & 6.18 & 8.92 & 167 & 1.08 & 10.2 & 68 & 39.3 & 41.5 \\
\hline 5.2 & 145 & 63.1 & 13.4 & 3.61 & 3.04 & 4.22 & 7.74 & 5.69 & 17.4 & 5.60 & 8.08 & 167 & 0.87 & 10.1 & 68 & 39.9 & 42.7 \\
\hline 5.3 & 150 & --- & 11.8 & 3.63 & 3.05 & 3.40 & 6.23 & 5.06 & 16.0 & 5.13 & 7.13 & 161 & 0.93 & 10.2 & 68 & 39.9 & 43.0 \\
\hline \multicolumn{18}{|l|}{ Shutdown } \\
\hline 5.3 & 174 & --- & 11.5 & 3.76 & 3.16 & 3.05 & 5.60 & 4.87 & 16.5 & 5.31 & 7.10 & 163 & 1.06 & 10.1 & 67 & 39.5 & 42.0 \\
\hline \multicolumn{18}{|l|}{ Nozzle Plug } \\
\hline 5.3 & --- & --- & 11.4 & 3.81 & 3.13 & 2.91 & 5.34 & 4.74 & 16.6 & 5.32 & 7.03 & 159 & --- & 10.6 & 69 & 40.0 & 41.3 \\
\hline \multicolumn{18}{|l|}{ Nozzle Plug } \\
\hline 5.3 & --- & --- & 13.4 & 4.45 & 3.73 & 3.66 & 6.72 & 5.80 & 18.7 & 6.00 & 8.16 & 165 & --- & 10.5 & 69 & 40.3 & 43.0 \\
\hline 5.3 average & --- & --- & 13.5 & 4.50 & 3.77 & 3.70 & 6.78 & 5.85 & 18.8 & 6.03 & 8.21 & 165 & --- & 10.5 & 69 & 40.3 & 43.1 \\
\hline 5.4 & 149 & 67.4 & 14.4 & 4.41 & 3.72 & 4.43 & 8.12 & 6.39 & 18.4 & 5.92 & 8.52 & 172 & 0.87 & 10.4 & 69 & 39.9 & 44.2 \\
\hline \multicolumn{18}{|l|}{ Nozzle Plug } \\
\hline 5.4 & 149 & 67.4 & 14.5 & 4.43 & 3.73 & 4.43 & 8.13 & 6.41 & 18.4 & 5.92 & 8.53 & 171 & 0.87 & 10.4 & 68 & 39.9 & 44.2 \\
\hline \multicolumn{18}{|l|}{ Nozzle Plug } \\
\hline 5.4 & 150 & --- & 14.2 & 4.16 & 3.50 & 4.39 & 8.04 & 6.19 & 18.3 & 5.88 & 8.46 & 170 & 0.88 & 10.4 & 68 & 39.8 & 43.6 \\
\hline 5.4 average & 150 & --- & 14.2 & 4.18 & 3.52 & 4.39 & 8.05 & 6.21 & 18.3 & 5.89 & 8.47 & 170 & 0.88 & 10.4 & 68 & 39.8 & 43.7 \\
\hline Overal average & 152 & 67.4 & 13.1 & 3.98 & 3.35 & 3.85 & 7.07 & 5.65 & 17.6 & 5.64 & 7.91 & 166 & 0.90 & 10.3 & 68 & 39.8 & 43.0 \\
\hline Std Dev & 6.2 & 0.9 & 1.5 & 0.66 & 0.52 & 0.78 & 1.44 & 0.81 & 1.2 & 0.37 & 0.75 & 6 & 0.08 & 0.2 & 1 & 0.5 & 2.8 \\
\hline
\end{tabular}


Appendix B

CEMS Calibrations 
Table B-1. CEMS1 calibration results for the TWR test series.

\begin{tabular}{|c|c|c|c|c|c|c|c|c|c|c|c|}
\hline \multirow[b]{3}{*}{ Date } & \multirow[b]{3}{*}{ Time } & \multirow[b]{3}{*}{ Calibration gas } & \multicolumn{4}{|c|}{ Servomex O2 } & \multicolumn{5}{|c|}{ AMETEK NO } \\
\hline & & & $\mathrm{FS}=$ & 25.00 & & & & $\mathrm{FS}=$ & $5,000.0$ & & \\
\hline & & & $\begin{array}{l}\text { Pre-Zero } \\
\text { Error }\end{array}$ & $\begin{array}{l}\text { Post-Zero } \\
\text { Error }\end{array}$ & $\begin{array}{c}\text { Pre-Span } \\
\text { Error }\end{array}$ & $\begin{array}{l}\text { Post-Span } \\
\text { Error }\end{array}$ & \begin{tabular}{|c|} 
Zero drift per \\
minute, \\
$\mathrm{ppm} / \mathrm{min}$
\end{tabular} & $\begin{array}{l}\text { Pre-Zero } \\
\text { error }\end{array}$ & $\begin{array}{l}\text { Post-Zero } \\
\text { Error }\end{array}$ & $\begin{array}{c}\text { Pre-Span } \\
\text { Error }\end{array}$ & $\begin{array}{c}\text { Post-Span } \\
\text { Error }\end{array}$ \\
\hline 19-Oct-03 & $?$ & Gas Conc. & --- & --- & --- & --- & --- & --- & $\overline{---}$ & --- & --- \\
\hline 19-Oct-03 & $?$ & Cal error, $\%$ of FS & --- & 0.32 & --- & -0.24 & --- & --- & 0.0 & --- & -6.2 \\
\hline 19-Oct-03 & 19:45 & Gas Conc. & --- & --- & --- & --- & --- & --- & --- & --- & --- \\
\hline 19-Oct-03 & 19:45 & Cal error, $\%$ of FS & --- & --- & --- & --- & --- & --- & --- & --- & --- \\
\hline $20-$ Oct-03 & $22: 00$ & Gas Conc. & --- & --- & --- & --- & --- & --- & --- & --- & --- \\
\hline $20-$-Oct-03 & $22: 00$ & Cal error, $\%$ of FS & -0.04 & -0.04 & --- & --- & -0.12 & -9.200 & 0.1 & --- & --- \\
\hline 20-Oct-03 & $22: 30$ & Gas Conc. & --- & --- & --- & --- & --- & --- & --- & --- & --- \\
\hline 20-Oct-03 & $22: 30$ & Cal error, $\%$ of FS & 0.00 & 0.00 & -0.05 & -0.01 & 0.00 & 0.000 & --- & -22.78 & -- \\
\hline 21-Oct-03 & $2: 10$ & Gas Conc. & --- & --- & --- & --- & --- & --- & --- & --- & --- \\
\hline 21-Oct-03 & $2: 10$ & Cal error, $\%$ of FS & --- & --- & --- & --- & 0.07 & 6.000 & --- & --- & --- \\
\hline 21-Oct-03 & 19:20 & Gas Conc. & --- & --- & --- & --- & --- & --- & --- & --- & --- \\
\hline 21-Oct-03 & 19:20 & Cal error, $\%$ of FS & --- & --- & --- & --- & --- & --- & --- & --- & --- \\
\hline 21 -Oct-03 & $20: 33$ & Gas Conc. & --- & --- & --- & --- & --- & --- & --- & --- & --- \\
\hline 21-Oct-03 & $20: 33$ & Cal error, $\%$ of FS & --- & --- & --- & --- & 0.00 & 0.000 & --- & 4.60 & --- \\
\hline $22-$ Oct-03 & $20: 35$ & Gas Conc. & --- & --- & --- & --- & --- & --- & --- & --- & --- \\
\hline $22-0 c t-03$ & $20: 35$ & Cal error, $\%$ of FS & 0.00 & 0.00 & --- & --- & -0.03 & -2.000 & --- & --- & --- \\
\hline $22-O c t-03$ & $22: 40$ & Gas Conc. & --- & --- & --- & --- & --- & --- & --- & --- & --- \\
\hline 22 -Oct-03 & $22: 40$ & Cal error, $\%$ of FS & 0.00 & 0.00 & 0.00 & --- & 0.00 & 0.000 & 0.0 & -7.20 & -4.4 \\
\hline $24-O c t-03$ & $14: 22$ & Gas Conc. & -- & --- & --- & --- & --- & --- & --- & --- & --- \\
\hline 24 -Oct-03 & $14: 22$ & Cal error, $\%$ of FS & 0.40 & 0.40 & --- & --- & 0.00 & -0.160 & --- & -0.58 & --- \\
\hline $24-O c t-03$ & 14:47 & Gas Conc. & --- & --- & --- & --- & --- & --- & --- & --- & --- \\
\hline $24-O c t-03$ & 14:47 & Cal error, $\%$ of FS & --- & --- & --- & --- & 0.25 & 19.300 & 0.0 & --- & --- \\
\hline $27-0 c t-03$ & $7: 22$ & Gas Conc. & --- & --- & --- & --- & --- & --- & --- & --- & --- \\
\hline $27-$ Oct-03 & $7: 22$ & Cal error, $\%$ of FS & --- & 0.08 & --- & --- & --- & --- & -0.1 & --- & --- \\
\hline $27-O c t-03$ & $7: 32$ & Gas Conc. & --- & --- & --- & --- & --- & --- & --- & --- & --- \\
\hline $27-0 c t-03$ & 7:32 & Cal error, $\%$ of FS & --- & 0.68 & --- & --- & 0.00 & 0.000 & 0.0 & -0.06 & 0.0 \\
\hline $27-$ Oct-03 & $7: 41$ & Gas Conc. & --- & --- & --- & --- & --- & --- & --- & --- & --- \\
\hline $27-$ Oct-03 & $7: 41$ & Cal error, $\%$ of FS & 0.00 & 0.00 & 1.20 & 0.00 & --- & --- & -0.2 & --- & --- \\
\hline 27 -Oct-03 & $11: 20$ & Gas Conc. & --- & --- & --- & --- & --- & --- & --- & --- & --- \\
\hline $27-$ Oct-03 & 11:20 & Cal error, $\%$ of FS & 0.00 & 0.00 & -0.40 & --- & 0.02 & 1.600 & --- & --- & --- \\
\hline $27-$-Oct-03 & $11: 25$ & Gas Conc. & --- & --- & --- & --- & --- & --- & --- & --- & --- \\
\hline $27-0 c t-03$ & 11:25 & Cal error, $\%$ of FS & 0.00 & 0.00 & --- & --- & 0.00 & 0.000 & -- & -1.12 & --- \\
\hline 28 -Oct-03 & $6: 40$ & Gas Conc. & --- & --- & --- & --- & --- & --- & --- & --- & --- \\
\hline 28 -Oct-03 & $6: 40$ & Cal error, $\%$ of FS & 0.00 & 0.00 & --- & --- & -0.05 & -3.520 & 0.0 & --- & --- \\
\hline $28-O c t-03$ & $7: 50$ & Gas Conc. & --- & -- & --- & --- & --- & --- & --- & --- & --- \\
\hline 28 -Oct-03 & 7:50 & Cal error, $\%$ of FS & 0.00 & --- & 0.00 & --- & -0.52 & -40.000 & --- & -1.82 & --- \\
\hline 28 -Oct-03 & $7: 52$ & Gas Conc. & -- & --- & --- & --- & --- & --- & --- & --- & --- \\
\hline 28 -Oct-03 & $7: 52$ & Cal error, $\%$ of FS & 0.00 & --- & --- & --- & 0.00 & 0.000 & 0.0 & -2.44 & -0.1 \\
\hline $29-\mathrm{Oct}-03$ & $7: 25$ & Gas Conc. & --- & --- & --- & --- & --- & -- & -- & --- & --- \\
\hline 29 -Oct-03 & $7: 25$ & Cal error, $\%$ of FS & --- & --- & --- & --- & 0.00 & 0.340 & 0.3 & -43.48 & --- \\
\hline 29-Oct-03 & $7: 40$ & Gas Conc. & --- & --- & --- & --- & --- & --- & --- & --- & --- \\
\hline $29-$ Oct-03 & $7: 40$ & Cal error, $\%$ of FS & 0.00 & 0.00 & 0.00 & 0.00 & 0.07 & 5.740 & 5.7 & --- & --- \\
\hline $29-$ Oct-03 & $7: 41$ & Gas Conc. & --- & --- & --- & --- & --- & --- & --- & --- & --- \\
\hline $29-$ Oct-03 & $7: 41$ & Cal error, $\%$ of FS & --- & --- & --- & --- & 0.00 & 0.000 & 0.0 & 2.06 & 0.0 \\
\hline 31-Oct-03 & $23: 00$ & Gas Conc. & --- & --- & --- & --- & --- & --- & --- & --- & -- \\
\hline 31-Oct-03 & $23: 00$ & Cal error, $\%$ of FS & -0.20 & -0.20 & 0.08 & --- & -0.06 & -4.500 & -- & --- & -- \\
\hline $31-$ Oct-03 & $23: 30$ & Gas Conc. & --- & --- & --- & --- & --- & --- & --- & --- & --- \\
\hline $31-$ Oct-03 & $23: 30$ & Cal error, $\%$ of FS & --- & --- & --- & --- & --- & --- & --- & --- & --- \\
\hline \multicolumn{3}{|c|}{ Average calibration error } & 0.01 & 0.09 & 0.12 & --- & -0.02 & -1.47 & 0.5 & -7.28 & -2.1 \\
\hline \multirow{2}{*}{\multicolumn{3}{|c|}{$\begin{array}{l}\text { Maximum calibration error } \\
\text { Minimum calibration error }\end{array}$}} & 0.40 & 0.68 & 1.20 & 0.00 & 0.25 & 19.30 & 5.7 & 4.60 & 0.0 \\
\hline & & & -0.20 & -0.20 & -0.40 & -0.24 & -0.52 & -40.00 & -0.2 & -43.48 & -6.2 \\
\hline \multirow{3}{*}{\multicolumn{6}{|c|}{$\begin{array}{l}\text { Adjust CEMS data for zero calibration error or dilution? } \\
\text { Adjust CEMS data for span calibration error? } \\
\text { Need to correct for bias? }\end{array}$}} & \multirow{2}{*}{\multicolumn{6}{|c|}{ no }} \\
\hline & & & & & & & & & & & \\
\hline & & & & & & at $16,500 p$ & opm CH4 averas & ge, the NO & orrection is & 1549 & \\
\hline
\end{tabular}


Table B-1. CEMS1 calibration results for the TWR test series (continued).

\begin{tabular}{|c|c|c|c|c|c|c|c|c|c|c|}
\hline \multicolumn{7}{|c|}{ Existing NOVA CO2 } & \multicolumn{4}{|c|}{ Existing NOVA H2 } \\
\hline & & & $\mathrm{FS}=$ & 100 & & & $\mathrm{FS}=$ & 5 & & \\
\hline Date & Time & Calibration gas & $\begin{array}{c}\text { Pre-Zero } \\
\text { Error }\end{array}$ & $\begin{array}{c}\text { Post-Zero } \\
\text { Error }\end{array}$ & $\begin{array}{c}\text { Pre-Span } \\
\text { Error }\end{array}$ & $\begin{array}{l}\text { Post-Span } \\
\text { Error }\end{array}$ & $\begin{array}{c}\text { Pre-Zero } \\
\text { Error }\end{array}$ & $\begin{array}{c}\text { Post-Zero } \\
\text { Error }\end{array}$ & $\begin{array}{c}\text { Pre-Span } \\
\text { Error }\end{array}$ & $\begin{array}{l}\text { Post-Span } \\
\text { Error }\end{array}$ \\
\hline 19-Oct-03 & $?$ & Gas Conc. & $\overline{---}$ & $\overline{---}$ & $\overline{---}$ & $\overline{---}$ & $\overline{---}$ & $\overline{---}$ & $\overline{---}$ & $\overline{---}$ \\
\hline 19-Oct-03 & $?$ & Cal error, $\%$ of FS & --- & 0.00 & --- & -0.10 & --- & 0.00 & --- & -0.36 \\
\hline 19-Oct-03 & $19: 45$ & Gas Conc. & --- & --- & --- & $\overline{---}$ & $\overline{---}$ & $\overline{---}$ & $\overline{---}$ & $\overline{---}$ \\
\hline 19-Oct-03 & $19: 45$ & Cal error, $\%$ of FS & --- & 0.00 & --- & --- & --- & 0.40 & --- & --- \\
\hline 20 -Oct-03 & $22: 00$ & Gas Conc. & --- & --- & --- & --- & --- & --- & --- & --- \\
\hline 20 -Oct-03 & $22: 00$ & Cal error, $\%$ of FS & -0.10 & 0.03 & --- & $-\ldots$ & 0.60 & 0.20 & --- & --- \\
\hline 20 -Oct-03 & $22: 30$ & Gas Conc. & --- & --- & --- & --- & --- & --- & --- & --- \\
\hline 20 -Oct-03 & $22: 30$ & Cal error, $\%$ of FS & 0.00 & 0.00 & 6.10 & 0.00 & 0.00 & 0.00 & 2.04 & 0.44 \\
\hline 21 -Oct-03 & $2: 10$ & Gas Conc. & --- & $-\ldots$ & --- & --- & $\overline{---}$ & $\overline{---}$ & $\overline{---}$ & $\overline{---}$ \\
\hline 21-Oct-03 & $2: 10$ & Cal error, $\%$ of FS & --- & $-\ldots$ & --- & --- & --- & --- & --- & --- \\
\hline 21-Oct-03 & $19: 20$ & Gas Conc. & --- & --- & --- & --- & --- & --- & --- & --- \\
\hline 21-Oct-03 & $19: 20$ & Cal error, $\%$ of FS & --- & --- & --- & --- & $\overline{---}$ & --- & --- & --- \\
\hline $21-$ Oct-03 & $20: 33$ & Gas Conc. & --- & --- & --- & --- & --- & --- & --- & --- \\
\hline $21-$ Oct-03 & $20: 33$ & Cal error, $\%$ of FS & -- & --- & --- & $\ldots$ & $\ldots$ & --- & $-\ldots$ & --- \\
\hline $22-$ Oct-03 & $20: 35$ & Gas Conc. & --- & --- & --- & --- & --- & --- & --- & --- \\
\hline $22-$ Oct-03 & $20: 35$ & Cal error, $\%$ of FS & 0.40 & 0.00 & 5.60 & 0.00 & 0.00 & 0.00 & --- & --- \\
\hline $22-$ Oct-03 & $22: 40$ & Gas Conc. & $\overline{---}$ & --- & --- & --- & $\overline{---}$ & $\overline{---}$ & --- & $\overline{---}$ \\
\hline 22 -Oct-03 & $22: 40$ & Cal error, $\%$ of FS & --- & --- & --- & --- & --- & --- & --- & --- \\
\hline 24-Oct-03 & $14: 22$ & Gas Conc. & --- & --- & --- & --- & --- & --- & --- & --- \\
\hline 24-Oct-03 & $14: 22$ & Cal error, $\%$ of FS & -0.10 & 0.00 & --- & --- & -6.00 & 0.00 & --- & --- \\
\hline 24 -Oct-03 & $14: 47$ & Gas Conc. & --- & --- & --- & --- & --- & --- & --- & --- \\
\hline 24 -Oct-03 & $14: 47$ & Cal error, $\%$ of FS & 0.10 & 0.10 & --- & --- & 4.00 & 4.00 & --- & --- \\
\hline $27-O c t-03$ & $7: 22$ & Gas Conc. & --- & --- & --- & --- & --- & --- & --- & --- \\
\hline 27 -Oct-03 & $7: 22$ & Cal error, $\%$ of FS & --- & 0.03 & --- & --- & --- & 0.60 & --- & --- \\
\hline $27-$ Oct-03 & $7: 32$ & Gas Conc. & --- & --- & --- & --- & --- & --- & --- & --- \\
\hline 27 -Oct-03 & $7: 32$ & Cal error, $\%$ of FS & --- & 0.03 & $-\ldots$ & --- & --- & 0.20 & --- & --- \\
\hline $27-$ Oct-03 & $7: 41$ & Gas Conc. & --- & --- & --- & --- & --- & --- & --- & --- \\
\hline $27-$ Oct-03 & $7: 41$ & Cal error, $\%$ of FS & 0.00 & 0.00 & 8.50 & 0.00 & --- & 0.00 & - & 0.84 \\
\hline 27-Oct-03 & $11: 20$ & Gas Conc. & --- & --- & --- & --- & --- & --- & --- & --- \\
\hline 27 -Oct-03 & $11: 20$ & Cal error, $\%$ of FS & 0.16 & --- & --- & --- & 6.00 & --- & --- & --- \\
\hline 27 -Oct-03 & $11: 25$ & Gas Conc. & --- & --- & --- & --- & --- & --- & --- & --- \\
\hline 27 -Oct-03 & $11: 25$ & Cal error, $\%$ of FS & --- & --- & --- & --- & --- & --- & --- & --- \\
\hline $28-$-Oct-03 & $6: 40$ & Gas Conc. & --- & --- & --- & --- & --- & --- & --- & --- \\
\hline 28 -Oct-03 & $6: 40$ & Cal error, $\%$ of FS & 0.60 & 0.03 & -- & -- & -4.00 & 0.20 & -- & -- \\
\hline 28 -Oct-03 & $7: 50$ & Gas Conc. & --- & --- & --- & --- & --- & --- & --- & --- \\
\hline $28-$ Oct-03 & $7: 50$ & Cal error, $\%$ of FS & 0.60 & 0.00 & 1.30 & 0.00 & 0.00 & 0.00 & 2.04 & 0.04 \\
\hline 28 -Oct-03 & $7: 52$ & Gas Conc. & --- & --- & --- & --- & --- & --- & --- & --- \\
\hline 28 -Oct-03 & $7: 52$ & Cal error, $\%$ of FS & -0.10 & -0.10 & --- & $-\ldots$ & 0.00 & 0.00 & --- & --- \\
\hline $29-$ Oct-03 & $7: 25$ & Gas Conc. & --- & --- & --- & --- & --- & --- & --- & --- \\
\hline 29 -Oct-03 & $7: 25$ & Cal error, $\%$ of FS & 1.50 & 1.50 & --- & --- & --- & --- & --- & --- \\
\hline 29-Oct-03 & $7: 40$ & Gas Conc. & --- & --- & --- & --- & --- & --- & --- & --- \\
\hline 29-Oct-03 & $7: 40$ & Cal error, $\%$ of FS & 0.90 & 0.03 & --- & --- & 2.00 & 0.00 & --- & --- \\
\hline $29-$ Oct-03 & $7: 41$ & Gas Conc. & --- & --- & --- & --- & --- & --- & --- & --- \\
\hline $29-$-Oct-03 & $7: 41$ & Cal error, $\%$ of FS & 0.00 & 0.00 & -4.80 & 0.00 & 0.00 & 0.00 & 0.04 & 0.04 \\
\hline $31-$ Oct-03 & $23: 00$ & Gas Conc. & --- & --- & --- & --- & --- & --- & --- & -- \\
\hline 31 -Oct-03 & $23: 00$ & Cal error, $\%$ of FS & 7.10 & --- & -1.50 & --- & 12.00 & --- & --- & $\overline{---}$ \\
\hline $31-$ Oct-03 & $23: 30$ & Gas Conc. & $-\ldots$ & $-\ldots$ & --- & --- & --- & --- & --- & --- \\
\hline 31 -Oct-03 & $23: 30$ & Cal error, $\%$ of FS & --- & $-\ldots$ & --- & --- & --- & --- & --- & --- \\
\hline \multicolumn{3}{|c|}{ Average calibration error } & 0.79 & 0.10 & 2.53 & -0.02 & 1.22 & 0.37 & 1.37 & 0.20 \\
\hline \multirow{2}{*}{\multicolumn{3}{|c|}{ Maximum calibration error }} & 7.10 & 1.50 & 8.50 & 0.00 & 12.00 & 4.00 & 2.04 & 0.84 \\
\hline & & & -0.10 & -0.10 & -4.80 & -0.10 & -6.00 & 0.00 & 0.04 & -0.36 \\
\hline \multicolumn{11}{|c|}{ Adjust CEMS data for zero calibration error or dilution? } \\
\hline \multicolumn{11}{|c|}{ Adjust CEMS data for span calibration error? } \\
\hline \multicolumn{11}{|c|}{ Need to correct for bias? } \\
\hline
\end{tabular}


Table B-1. CEMS1 calibration results for the TWR test series (continued).

\begin{tabular}{|c|c|c|c|c|c|c|c|c|c|c|c|}
\hline \multicolumn{7}{|c|}{$\mathrm{CAICO}$} & \multicolumn{4}{|c|}{$\mathrm{CAl} \mathrm{CH} 4$} & \multirow[b]{3}{*}{ Comments } \\
\hline & & & $\mathrm{FS}=$ & \multicolumn{2}{|l|}{10.00} & & $\mathrm{FS}=$ & \multicolumn{2}{|c|}{\begin{tabular}{|l|l|}
50,000 & \\
\end{tabular}} & & \\
\hline Date & Time & Calibration gas & $\begin{array}{c}\text { Pre-Zero } \\
\text { Error }\end{array}$ & $\begin{array}{l}\text { Post-Zero } \\
\text { Error }\end{array}$ & $\begin{array}{c}\text { Pre-Span } \\
\text { Error }\end{array}$ & $\begin{array}{c}\text { Post-Span } \\
\text { Error }\end{array}$ & $\begin{array}{c}\text { Pre-Zero } \\
\text { Error }\end{array}$ & $\begin{array}{l}\text { Post-Zero } \\
\text { Error }\end{array}$ & $\begin{array}{c}\text { Pre-Span } \\
\text { Error }\end{array}$ & $\begin{array}{l}\text { Post-Span } \\
\text { Error }\end{array}$ & \\
\hline 19-Oct-03 & $?$ & Gas Conc. & -- & -- & --- & --- & -- & -- & -- & -- & \\
\hline 19-Oct-03 & ? & Cal error, $\%$ of FS & --- & 0.00 & --- & 0.00 & --- & 0.00 & --- & -0.73 & \\
\hline 19-Oct-03 & 19:45 & Gas Conc. & --- & --- & --- & --- & --- & --- & --- & --- & \\
\hline 19-Oct-03 & 19:45 & Cal error, $\%$ of FS & --- & 0.00 & --- & --- & --- & 0.00 & --- & --- & \\
\hline $20-$-Oct-03 & $22: 00$ & Gas Conc. & --- & --- & --- & --- & --- & --- & --- & --- & \\
\hline $20-$-Oct-03 & $22: 30$ & Gas Conc. & --- & --- & -- & --- & --- & --- & --- & --- & Ihias calibration \\
\hline 20-Oct-03 & $22: 30$ & Cal error, $\%$ of FS & 0.00 & --- & -0.60 & -0.60 & 0.00 & 0.00 & 0.42 & 0.00 & \\
\hline 21-Oct-03 & $2: 10$ & Gas Conc. & --- & -- & --- & -- & --- & --- & -- & -- & \\
\hline 21-Oct-03 & $2: 10$ & Cal error, $\%$ of FS & --- & $\ldots$ & -- & --- & --- & --- & --- & --- & \\
\hline 21-Oct-03 & $19: 20$ & Gas Conc. & --- & -- & --- & -- & --- & --- & -- & -- & \\
\hline 21-Oct-03 & 19:20 & Cal error, $\%$ of FS & 0.00 & --- & --- & --- & 0.69 & --- & --- & --- & \\
\hline 21-Oct-03 & $20: 33$ & Gas Conc. & --- & --- & -- & --- & --- & --- & -- & --- & \\
\hline 21-Oct-03 & $20: 33$ & Cal error, $\%$ of FS & --- & $\ldots$ & --- & --- & 14.00 & 0.00 & 6.00 & 0.00 & \\
\hline 22-Oct-03 & $20: 35$ & Gas Conc. & --- & --- & --- & --- & --- & --- & $-\cdots$ & -- & \\
\hline 22-Oct-03 & $22: 40$ & Gas Conc. & --- & --- & --- & --- & --- & --- & --- & --- & \\
\hline 22-Oct-03 & $22: 40$ & Cal error, $\%$ of FS & 0.00 & 0.00 & -0.30 & 0.00 & 1.80 & 0.00 & 0.18 & 0.00 & \\
\hline 24-Oct-03 & $14: 22$ & Gas Conc. & --- & --- & --- & --- & --- & --- & --- & --- & \\
\hline $24-O c t-03$ & $14: 22$ & Cal error, $\%$ of FS & 1.40 & 0.00 & --- & --- & 0.12 & --- & --- & --- & \\
\hline 24-Oct-03 & 14:47 & Gas Conc. & --- & --- & -- & --- & --- & --- & --- & --- & \\
\hline $24-O c t-03$ & $14: 47$ & Cal error, $\%$ of FS & -0.30 & 0.00 & --- & --- & 0.22 & 0.22 & --- & --- & \\
\hline 27-Oct-03 & $7: 22$ & Gas Conc. & --- & --- & --- & --- & --- & --- & --- & -- & \\
\hline $27-$ Oct-03 & $7: 22$ & Cal error, $\%$ of FS & --- & 0.00 & --- & --- & --- & 0.31 & --- & --- & \\
\hline $27-$ Oct-03 & $7: 32$ & Gas Conc. & --- & --- & --- & --- & --- & --- & --- & --- & bias calibration \\
\hline $27-0 c t-03$ & $7: 32$ & Cal error, $\%$ of FS & --- & 0.00 & --- & --- & --- & 0.33 & $-\cdots$ & --- & 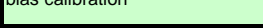 \\
\hline $27-$ Oct-03 & 7:41 & Gas Conc. & --- & --- & --- & --- & --- & --- & --- & --- & \\
\hline $27-$ Oct-03 & $7: 41$ & Cal error, $\%$ of FS & 0.00 & 0.00 & 0.80 & 0.00 & 0.32 & 0.32 & -3.34 & -0.32 & \\
\hline $27-$ Oct-03 & $11: 20$ & Gas Conc. & --- & --- & --- & --- & --- & --- & --- & --- & \\
\hline $27-$ Oct-03 & $11: 20$ & Cal error, $\%$ of FS & 0.00 & --- & --- & --- & 0.47 & --- & --- & --- & \\
\hline $27-$ Oct-03 & $11: 25$ & Gas Conc. & --- & --- & --- & -- & --- & -- & -- & -- & \\
\hline 27-Oct-03 & 11:25 & Cal error, $\%$ of FS & --- & --- & --- & --- & --- & -- & --- & --- & \\
\hline 28-Oct-03 & $6: 40$ & Gas Conc. & --- & --- & --- & --- & --- & --- & --- & --- & \\
\hline 28-Oct-03 & $6: 40$ & Cal error, $\%$ of FS & -0.10 & 0.00 & --- & --- & 0.93 & 0.93 & --- & --- & \\
\hline $28-O c t-03$ & $7: 50$ & Gas Conc. & --- & --- & --- & --- & --- & --- & --- & --- & Bias calibration for Ametek NO \\
\hline 29-Oct-03 & $7: 25$ & Gas Conc. & --- & --- & --- & --- & --- & --- & $-\cdots$ & $-\cdots$ & Bias calibrations \\
\hline 29-Oct-03 & 7:25 & Cal error, $\%$ of FS & -0.40 & -0.40 & -0.90 & -- & 3.58 & 3.58 & & -- & 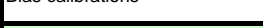 \\
\hline 29-Oct-03 & $7: 40$ & Gas Conc. & --- & --- & -- & --- & --- & --- & --- & --- & \\
\hline 29-Oct-03 & $7: 40$ & Cal error, $\%$ of FS & -0.60 & 0.00 & --- & --- & 1.48 & 1.37 & --- & --- & \\
\hline 29-Oct-03 & $7: 41$ & Gas Conc. & --- & --- & --- & --- & --- & --- & --- & --- & \\
\hline 29-Oct-03 & $7: 41$ & Cal error, $\%$ of FS & 0.00 & 0.00 & -0.30 & -0.10 & 1.48 & 0.00 & -0.40 & 0.01 & \\
\hline 31-Oct-03 & $23: 00$ & Gas Conc. & -- & --- & -- & --- & --- & --- & $-\cdots$ & -- & \\
\hline 31-Oct-03 & $23: 00$ & Cal error, $\%$ of FS & 0.00 & -- & 0.00 & --- & 0.44 & --- & 2.82 & --- & \\
\hline 31-Oct-03 & $23: 30$ & Gas Conc. & --- & --- & --- & --- & --- & --- & --- & --- & \\
\hline 31-Oct-03 & 23:30 & Cal error, $\%$ of FS & -- & -- & -- & -- & -- & -- & $\ldots$ & -- & \\
\hline Average calib & ion error & & -0.03 & -0.03 & -0.17 & -0.10 & 1.61 & 0.56 & 0.78 & -0.18 & \\
\hline Maximum cal & ation erro & & 1.40 & 0.00 & 0.80 & 0.10 & 14.00 & 3.58 & 6.00 & 0.01 & \\
\hline Minimum cali & tion error & & -0.60 & -0.40 & -0.90 & -0.60 & 0.00 & 0.00 & -3.34 & -0.73 & \\
\hline Adjust CEMS & ta for zer & ation error or dilution? & & no & & & & & & & \\
\hline Adjust CEMS & ta for spe & ation error? & & no & & & & & & & \\
\hline Need to corre & for bias? & & & & & & & & & & \\
\hline
\end{tabular}




\section{Appendix C}

\section{Quality Assurance/Quality Control Activities and Results}




\section{Appendix C}

\section{Quality Assurance/Quality Control Activities and Results}

Several different quality assurance/quality control (QA/QC) activities have been performed for this test series to characterize the quality of the test data and to ensure sufficient data quality to meet the data quality objectives. QA/QC activities have been grouped as either qualitative or quantitative. Qualitative QA parameters are comparability and representativeness.

\section{C-1. DATA QUALITY OBJECTIVES}

Data quality objectives include qualitative and quantitative objectives that define the QA/QC activities for this test series. Data from this test are to be used in engineering and feasibility evaluations of steam reforming technology and to demonstrate off-gas treatment technologies. The data are not intended for treatment facility design or operation. As such, the data are not collected to be quality-controlled data. The QA/QC activities have been defined to characterize the quality of the test data and to ensure sufficient data quality to meet the data quality objectives.

\section{C-1.1 Qualitative QA/QC Activities}

Several activities were performed to characterize and ensure representativeness and comparability of test data. Representativeness is a measure to which sample data accurately and precisely represent the average properties being measured. Comparability is the determination that one data set can be compared to another. These qualitative characteristics involve all aspects of the work, including preparation for sampling, sampling, sample handling, analytical method performance, data validation, and reporting of results. Comparability and representativeness in this project were achieved by the following:

- $\quad$ Appropriate planning and calibrations

- Documentation of all laboratory data, general observations, and details of the activities in a Laboratory Record Books (LRBs), data entry sheets, and electronic data logs

- $\quad$ Collecting samples and making measurements from specific approved locations in the steam reformer system

- $\quad$ Using standard procedures for calibrations where possible

- $\quad$ Using sampling and analytical procedures based on standard methods where possible

- Documenting all necessary deviations from standard procedures, sample preparation methods, or analytical methods

- Using standard procedures or procedures that are developed for this test program that are checked for accuracy for all data reductions and emissions calculations.

\section{C-1.2 Quantitative QA/QC Activities}

Quantitative QA/QC activities include calibrations and other measurements that quantify data precision and accuracy. Precision is a measure of the agreement among individual measurements of the 
same parameter under similar conditions. Accuracy is the degree of agreement of a measurement with a true or known value.

Key process control, safety-related, and off-gas characterization instruments and the data collection loops were calibrated for reliability and data quality. Results of the calibrations are shown in Table C- 1 . Calibration procedures and records are maintained in the project files. The accuracy of the process instrumentation and software has also been demonstrated in prior steam reforming tests (Marshall 2003a, Marshall 2003c, Soelberg 2003a).

The CEMS accuracy, calibrations, and quality assurance checks are discussed in Sections 5 and 6. The calibration results are summarized in Appendix B.

Many samples were collected and analyzed for this test series. Several QA/QC activities were performed to characterize and ensure sample analysis precision and accuracy. Results of these QA/QC activities are shown in Table C-2.

\section{C-2. SAMPLE HANDLING AND CUSTODY}

Gaseous, liquid, and solid samples were collected for analysis in this test program. New sample containers were used that were appropriate to the sample matrix. Sample containers were kept in a clean environment, in original shipping boxes, and covered, until needed.

All samples were labeled with a unique identifying number and with other information that describes the sample to field, shipping, and laboratory personnel. The label identified the unique sample number, project name, sample description, sample date and time, and sampler name or initials. The sample description will include the location of sample collection and the sample matrix. This same information along with any additional detail information, including sample volume or weight, requests for analysis, and chain of custody information, were recorded in a sample log and on request for analysis/chain of custody (RFA/COC) forms.

Samples were transported according to INEEL requirements. Samples that were not hazardous were not Department of Transportation (DOT) regulated, and were freely transported by test team personnel using a government vehicle (Rowley 2003). Samples that were hazardous were regulated by DOT. DOT provides a "Materials of Trade Exception" (49CFR173.6), which allowed transport by test team personnel by meeting shipping requirements that included (a) securing the samples in an outer container, so that there would not be breakage, leakage, or spillage during transportation, (b) securing the container in a government vehicle, and (c) properly labeling the samples.

\section{C-3. DATA REDUCTION, REVIEW, VALIDATION AND REPORTING}

Key process data and CEMS data were recorded manually on data sheets and recorded automatically in electronic data files. The electronic data files were imported into spreadsheet formats for data reduction and presentation. Onsite data reduction will be performed to the extent possible. Process data from the PLC was incorporated with CEMS data and available sample analysis data to characterize the process inputs, outputs, operating conditions. 
Table C-1. Calibrated instrument accuracies for the fluidized bed test system.

\begin{tabular}{|c|c|c|c|c|}
\hline Tag Name & Description & Manufacturer & Technology & Accuracy \\
\hline AJ1 F1_VAL & Off-Gas Mass Flow to GAC (kg/hr) & Micro Motion & Coriolis & $+0.044 \%$ \\
\hline AJ1_P2_VAL & Off-gas Pressure at Reheater RH-2 Discharge (PSIA) & Rosemount & Capacitive & $0.2 \%$ Span \\
\hline AJ1_T1_VAL & Off-Gas Temperature at GAC Inlet (oC) & Idaho Lab & Type K & $\pm 2.2^{\circ} \mathrm{C}$ \\
\hline B1_A1_O2 & Raw Oxygen Concentration at B-1 Oxidizer Discharge (Wet Basis) (\%) & Ametek & Zirconium Oxide & $\pm 0.75 \%($ measured $)$ \\
\hline B1_F1_VAL & Natural Gas Mass Flow to B-1 Burner $(\mathrm{kg} / \mathrm{hr})$ & Micro Motion & Coriolis & $+0.044 \%$ \\
\hline B1_F2_VAL & Air Mass Flow to B-1 Burner $(\mathrm{kg} / \mathrm{hr})$ & Micro Motion & Coriolis & $+0.044 \%$ \\
\hline B1_F3_VAL & Air Mass Flow to B-1 Oxidizer $(\mathrm{kg} / \mathrm{hr})$ & Micro Motion & Coriolis & $\pm 0.044 \%$ \\
\hline B1_F4_VAL & Cooling Water Mass Flow to B-1 Oxidizer $(\mathrm{kg} / \mathrm{hr})$ & Micro Motion & Coriolis & $\pm 0.044 \%$ \\
\hline B1_T1_VAL & Temperature in B-1 Oxidizer $(\operatorname{deg} \mathrm{C})$ & Idaho Lab & Type K & $\pm 2.2^{\circ} \mathrm{C}$ \\
\hline B1_T2_VAL & Temperature at B-1 Oxidizer Discharge $(\operatorname{deg} C)$ & Idaho Lab & Type K & $\pm 2.2^{\circ} \mathrm{C}$ \\
\hline C1_PD_VAL & Differential Pressure Across C-1 Cyclone (inH2O) & Rosemount & DP Cell & $0.25 \%$ Span \\
\hline C1_T1_VAL & Off-gas Temperature at C-1 Cyclone Inlet (oC) & Idaho Lab & Type K & $\pm 2.2^{\circ} \mathrm{C}$ \\
\hline $\mathrm{C} 1 \_\mathrm{T} 2$-VAL & Off-gas Temperature in $\mathrm{C}-1$ Cyclone $(\mathrm{oC})$ & Idaho Lab & Type K & $\pm 2.2^{\circ} \mathrm{C}$ \\
\hline C1_T3_VAL & Off-gas Temperature at C-1 Cyclone Discharge (oC) & Idaho Lab & Type K & $\pm 2.2^{\circ} \mathrm{C}$ \\
\hline EVS1_F2_VAL & Scrub Solution Volume Flow to EVS-1 Scrubber $(1 / \mathrm{hr})$ & Yokogawa & Mag. & $0.25 \%$ of Span \\
\hline EVS1_PD1_VAL & Differential Pressure Across EVS-1 Scrubber (inH2O) & Rosemount & DP Cell & $0.2 \%$ Span \\
\hline F1_PD_VĀ & Differential Pressure Across F-1 Filter Vessel (inH2O) & Rosemount & DP Cell & $.25 \%$ Span \\
\hline F1_T1_VAL & Off-gas Temperature in F-1 Filter Vessel (oC) & Idaho Lab & Type K & $\pm 2.2^{\circ} \mathrm{C}$ \\
\hline F1_T2_VAL & Off-gas Temperature at F-1 Filter Vessel Discharge (oC) & Idaho Lab & Type K & $\pm 2.2^{\circ} \mathrm{C}$ \\
\hline GAC1_PD_VAL & Differential Pressure Across GAC (inH2O) & DWYER & DP Cell & $2 \%$ of Scale \\
\hline GAC1_T_VAL & Temperature 1 in GAC (oC) & Idaho Lab & Type K & $\pm 2.2^{\circ} \mathrm{C}$ \\
\hline GAC1_T2_VAL & Temperature 2 in GAC (oC) & Idaho Lab & Type K & $\pm 2.2^{\circ} \mathrm{C}$ \\
\hline H1_F_PV & Steam Mass Flow to Fluidized Bed $(\mathrm{kg} / \mathrm{hr})$ & Rosemount & Mass ProPlate & $1 \%$ Range \\
\hline $\mathrm{H} 1$ F 2 2_PV & Fluidizing Gas Mass Flow to Fluidized Bed $(\mathrm{kg} / \mathrm{hr})$ & Micro Motion & Coriolis & $+0.044 \%$ \\
\hline H1_T1_VAL & Process Gas Temperature at H-1 Superheater Inlet (oC) & Rosemount & Mass ProPlate & $\pm .56^{\circ} \mathrm{C}$ \\
\hline H1_T2_VAL & Process Gas Temperature at $\mathrm{H}-1$ Superheater Discharge $(\mathrm{oC})$ & Idaho Lab & Type R & $\pm 2.2^{\circ} \mathrm{C}$ \\
\hline H1_T2B_Val & Pipe Temperature in $\mathrm{H}-1$ Superheater $(\mathrm{oC})$ & Idaho Lab & Type K & $\pm 2.2^{\circ} \mathrm{C}$ \\
\hline $\mathrm{H} 2{ }_{-}^{-} \mathrm{T}+\mathrm{VA} \mathrm{L}$ & Process Gas Temperature at $\mathrm{H}-1$ Superheater Discharge $(\mathrm{oC})$ & Idaho Lab & Type R & $\pm 2.2^{\circ} \mathrm{C}$ \\
\hline $\mathrm{H} 2 \_\mathrm{TB} \_\mathrm{Val}$ & Pipe Temperature in $\mathrm{H}-2$ Superheater $(\mathrm{oC})$ & Idaho Lab & Type R & $\pm 2.2^{\circ} \mathrm{C}$ \\
\hline H3_T1_VAL & Pipe Temperature in H-3 Superheater (oC) & Idaho Lab & Type R & $\pm 2.2^{\circ} \mathrm{C}$ \\
\hline $\mathrm{H} 3{ }_{-}^{-} 2_{2}^{-} \mathrm{VAL}$ & Process Gas Temperature at $\mathrm{H}-3$ Superheater Discharge $(\mathrm{oC})$ & Idaho Lab & Type K & $\pm 2.2^{\circ} \mathrm{C}$ \\
\hline H4_T1_VAL & Pipe Temperature in H-4 Superheater (oC) & Idaho Lab & Type R & $\pm 2.2^{\circ} \mathrm{C}$ \\
\hline $\mathrm{H} 4{ }_{-}^{-} \mathrm{T} 2 \_\mathrm{V}$ - $\mathrm{AL}$ & Process Gas Temperature at $\mathrm{H}-4$ Superheater Discharge $(\mathrm{oC})$ & Idaho Lab & Type R & $\pm 2.2^{\circ} \mathrm{C}$ \\
\hline MĒ1_PD1_VAL & Differential Pressure across the Mist Eliminator (inH2O) & Rosemount & DP Cell & $0.25 \%$ Span \\
\hline PQ1_F1_VAL & Cooling Water Mass Flow to PQ-1 Partial Quench $(\mathrm{kg} / \mathrm{hr})$ & Micro Motion & Coriolis & $+0.044 \%$ \\
\hline PQ1_PD1_VAL & Differential Pressure Across PQ-1 Partial Quench (in H2O) & Rosemount & DP Cell & $0.25 \%$ Span \\
\hline PQ1_T1_V̄AL & Temperature at PQ-1 Partial Quench Discharge (deg C) & Idaho Lab & Type K & $\pm 2.2^{\circ} \mathrm{C}$ \\
\hline SR1_D1A_VAL & Simulant Feed Density $(\mathrm{gm} / \mathrm{cc})$ & Micro Motion & Coriolis & $+0.044 \%$ \\
\hline SR1_D1C_VAL & Reductant Feed Density (gm/cc) & Micro Motion & Coriolis & $\pm 0.044 \%$ \\
\hline SR1_F1A_VAL & Simulant Feed Mass Flow to Fluidized Bed $(\mathrm{kg} / \mathrm{hr})$ & Micro Motion & Coriolis & $\pm 0.044 \%$ \\
\hline SR1_F1B_KGH & Atomizing Calculated Mass Flow Rate Based on Raw Value from MFC & Brooks & Thermal Anem & $1 \%$ of Setpoint \\
\hline SR1_F1C_VAL & Reductant Feed Mass Flow to Fluidized Bed (kg/hr) & Micro Motion & Coriolis & $+0.044 \%$ \\
\hline SR1_F2_KGGH & O2 to Distributer Plate Calculated Mass Flow Rate Based on Raw Value from MFC (THOR) & Brooks & Thermal Anem & $\overline{1 \%}$ of Setpoint \\
\hline SR1_F3_KGH & Atomizing O2 Calculated Mass Flow Rate Based on Raw Value from MFC & Brooks & Thermal Anem & $1 \%$ of Setpoint \\
\hline SR1_P1_VAL & Pressure at Bottom of Fluidized Bed (PSIA) & Rosemount & Capacitive & $0.2 \%$ Span \\
\hline SR1_PD1_VAL & Differential Pressure Across Distributor Plate (inH2O) & Rosemount & DP Cell & $0.25 \%$ of Span \\
\hline SR1_PD2_VAL & Differential Pressure Across Lower 13 in of Fluidized Bed (Density) (inH2O) & Rosemount & DP Cell & $0.25 \%$ of Span \\
\hline SR1_PD3_VAL & Differential Pressure Across Fluidized Bed (inH2O) & Rosemount & DP Cell & $0.25 \%$ of Span \\
\hline SR1_T11_VAL & Wall Temperature of Upper Disengaging Section (oC) & Idaho Lab & Type K & $\pm 2.2^{\circ} \mathrm{C}$ \\
\hline SR1_T12_VAL & Wall Temperature of Mid Disengaging Section (oC) & Idaho Lab & Type K & $\pm 2.2^{\circ} \mathrm{C}$ \\
\hline SR1_T13_VAL & Wall Temperature of Lower Disengaging Section (oC) & Idaho Lab & Type K & $\pm 2.2^{\circ} \mathrm{C}$ \\
\hline SR1_T15_VAL & Cooling Water Jacket Temperature on Feed Nozzle (oC) & Idaho Lab & Type K & $\pm 2.2^{\circ} \mathrm{C}$ \\
\hline SR1_T19_VAL & Wall Temperature of Upper Fluidized Bed (oC) & Idaho Lab & Type K & $\pm 2.2^{\circ} \mathrm{C}$ \\
\hline SR1_T2_VAL & Bed Temperature at Bottom of Fluidized Bed (oC) & Idaho Lab & Type K & $\pm 2.2^{\circ} \mathrm{C}$ \\
\hline SR1_T20_VAL & Wall Temperature of Lower Fluidized Bed (oC) & Idaho Lab & Type K & $\pm 2.2^{\circ} \mathrm{C}$ \\
\hline SR1_T3_VAL & Bed Temperature at 5in Fluidized Bed Height (oC) & Idaho Lab & Type K & $\pm 2.2^{\circ} \mathrm{C}$ \\
\hline SR1_T4_VAL & Bed Temperature at 11 in Fluidized Bed Height $(\mathrm{oC})$ & Idaho Lab & Type K & $\pm 2.2^{\circ} \mathrm{C}$ \\
\hline SR1_T5_VAL & Bed Temperature at 17in Fluidized Bed Height (oC) & Idaho Lab & Type K & $\pm 2.2^{\circ} \mathrm{C}$ \\
\hline SR1_T6_VAL & Bed Temperature at 23in Fluidized Bed Height $(\mathrm{oC})$ & Idaho Lab & Type K & $\pm 2.2^{\circ} \mathrm{C}$ \\
\hline SR1_T7_VAL & Off-gas Temperature in Lower Disengaging Section (oC) & Idaho Lab & Type K & $\pm 2.2^{\circ} \mathrm{C}$ \\
\hline SR1_T8_VAL & Off-gas Temperature in Mid Disengaging Section (oC) & Idaho Lab & Type K & $\pm 2.2^{\circ} \mathrm{C}$ \\
\hline SR1 T9 VAL & Off-gas Temperature in Upper Disengaging Section (oC) & Idaho Lab & Type K & $\pm 2.2^{\circ} \mathrm{C}$ \\
\hline T7_P_VAL & Vapor Space Pressure in T-7 Tank (PSIA) & Rosemount & Capacitive & $0.2 \%$ Span \\
\hline T7_T1_VAL & Scrub Solution Temperature in T-7 Tank (oC) & Idaho Lab & Type K & $\pm 2.2^{\circ} \mathrm{C}$ \\
\hline T7_T2_VAL & Off-gas Temperature at Tank T-7 Discharge (oC) & Idaho Lab & Type K & $\pm 2.2^{\circ} \mathrm{C}$ \\
\hline V1_F1_VAL & Gas Supply Mass Flow at System Inlet $(\mathrm{kg} / \mathrm{hr})$ & Micro Motion & Coriolis & $+0.044 \%$ \\
\hline
\end{tabular}


Table C-2. Precision, accuracy, and detection limits for critical laboratory measurements.

\begin{tabular}{|c|c|c|c|c|c|c|}
\hline \multicolumn{2}{|c|}{ Measurement } & $\begin{array}{c}\text { Method } \\
\text { (a) }\end{array}$ & $\begin{array}{l}\text { Detection Limits, } \\
\mathrm{mg} / \mathrm{kg} \text { or } \mathrm{mg} / \mathrm{L}\end{array}$ & $\begin{array}{l}\text { Precision, \% RPD for } \\
\text { Duplicate Analyses (b) }\end{array}$ & $\begin{array}{l}\text { Accuracy, \% } \\
\text { Error of CCV }\end{array}$ & $\begin{array}{l}\text { Matrix Spike, } \\
\% \text { recovery }\end{array}$ \\
\hline \multirow[t]{2}{*}{ Nitrate } & $\mathrm{NO}_{2}$ & \multirow[t]{2}{*}{$\mathrm{IC}$} & 0.059 & 3.00 & $0.5 \pm 3.4$ & 108 \\
\hline & $\mathrm{NO}_{3}$ & & 0.3 & 1.35 & $5.4+4.1$ & 106 \\
\hline \multirow[t]{2}{*}{ Carbon } & TIC & \multirow[t]{2}{*}{ PUO-IM } & --- & 18.9 & --- & --- \\
\hline & TOC & & --- & 18.2 & --- & --- \\
\hline \multirow[t]{20}{*}{ Elemental } & $\mathrm{Al}$ & ICP-AES & 0.065 & 3.89 & $7.8 \pm 0.7$ & 92.8 \\
\hline & B & ICP-AES & 0.056 & 0.30 & $4.2 \pm 0.6$ & 89.6 \\
\hline & $\mathrm{Ca}$ & ICP-AES & 0.019 & 3.71 & $0.6 \pm 0.6$ & 101 \\
\hline & Cs & ICP-MS & 0.312 & 4.45 & $-0.6 \pm 0.7$ & 98.3 \\
\hline & $\mathrm{Cr}$ & ICP-AES & 0.014 & 2.35 & $-0.4 \pm 0.6$ & 99.2 \\
\hline & $\mathrm{Cu}$ & ICP-AES & 0.016 & 34.4 & $-1.7 \pm 0.8$ & 99.2 \\
\hline & $\mathrm{Fe}$ & ICP-AES & 0.014 & 3.37 & $1.9 \pm 2.0$ & 95.1 \\
\hline & $\mathrm{Hg}$ & CVAA & 0.010 & 4.05 & --- & --- \\
\hline & $\mathrm{K}$ & ICP-AES & 0.136 & 5.02 & $-4.0 \pm 1.5$ & 99.1 \\
\hline & $\mathrm{Mg}$ & ICP-AES & 0.003 & 9.80 & $4.0 \pm 0.5$ & 113 \\
\hline & $\mathrm{Mn}$ & ICP-AES & 0.004 & 6.95 & $0.6 \pm 0.5$ & 99.1 \\
\hline & $\mathrm{Na}$ & ICP-AES & 0.048 & 4.26 & $4.9 \pm 1.6$ & 95.4 \\
\hline & $\mathrm{Ni}$ & ICP-AES & 0.006 & 3.15 & $-1.2 \pm 0.9$ & 99.5 \\
\hline & $\mathrm{Pb}$ & ICP-AES & 0.015 & 27.4 & $9.4 \pm 1.5$ & --- \\
\hline & $\mathrm{Re}$ & ICP-MS & 0.033 & 55.4 & $-4.2 \pm 1.6$ & 97.9 \\
\hline & $\mathrm{S}$ & ICP-AES & 0.037 & --- & $-1.5 \pm 1.2$ & --- \\
\hline & $\mathrm{Si}$ & ICP-AES & 0.036 & 8.45 & $2.3 \pm 1.8$ & 103 \\
\hline & $\mathrm{Sn}$ & ICP-AES & 0.025 & --- & $12.5 \pm 1.6$ & 110 \\
\hline & $\mathrm{Zn}$ & ICP-AES & 0.004 & 14.4 & $-1.9 \pm 0.7$ & 104 \\
\hline & $\mathrm{Zr}$ & ICP-AES & 0.011 & 64.2 & $6.0 \pm 0.4$ & 102 \\
\hline \multirow[t]{3}{*}{ Anions } & $\mathrm{Cl}$ & \multirow[t]{3}{*}{$\mathrm{IC}$} & 0.082 & 4.00 & $1.0 \pm 2.0$ & --- \\
\hline & $\mathrm{F}$ & & 0.092 & 5.00 & $1.9 \pm 2.0$ & -- \\
\hline & $\mathrm{SO}_{4}$ & & 0.293 & --- & $4.1 \pm 2.7$ & 103 \\
\hline
\end{tabular}

a. Ion Chromatography (IC), Persulfate-Ultraviolet Oxidation/Combustion-Infrared method 5310B/C (PUO-IM), Inductively Coupled Plasma Atomic Emission Spectroscopy (ICP-AES), Cold Vapor Atomic Absorption (CVAA)

b. $R P D=$ Relative percent difference $=2 \times($ Measurement $2-$ Measurement 1$) /($ Measurement $1+$ Measurement 2$) \times 100 \%$ Goal for precision is $\pm 5 \%$ relative percent difference (RPD).

Goal for accuracy is $\pm 20 \%$ error for continuing calibration verifications (CCVs).

Goal for accuracy is $100 \pm 20 \%$ for Matrix spike recovery 
The CEMS data reductions included:

- Calculation of instantaneous and average off-gas composition

- $\quad$ Calculation of CEMS zero and span drifts

- $\quad$ Correction of CEMS data for calculated drift if zero or span drift exceeds acceptance limits

- $\quad$ Correction of CEMS data for any dilutions

- $\quad$ Calculation of concentrations on a representative basis (such as wet or dry basis).

All calculations in the PLC and in data reduction spreadsheets were validated by limited sampling of hand calculations and by limited comparisons to other validated results from prior tests.

Laboratory data were flagged if conditions during analysis such as proximity to detection limits or full-scale values, interferences, or blank values cause the data to be suspect.

\section{C-4. INTERNAL QUALITY CONTROL CHECKS AND SPECIFIC ROUTINE PROCEDURES FOR QUALITY ASSURANCE}

Internal quality control checks for this project included quality assurance/quality control (QA/QC) samples, calibration checks, equipment maintenance and handling, and protocols or procedures specified in each of the sampling and analysis methods.

QA/QC samples included blank and duplicate samples. Duplicate samples were used to indicate analytical precision.

Test system and sampling equipment was inspected when it was used for functionality, cleanliness, wear, corrosion, or other issues that could affect its performance for this test program. The CEMS operations included routine inspections and maintenance of all components, leak checks, zero and span calibrations, linearity checks, bias checks, interference checks, drift checks, sample gas flow rate and pressure monitoring and control, dilution checks, and temperature monitoring and control. Test personnel used laboratory notebooks and data sheets to maintain orderly and well-documented records of the test program. 